RENATO SILVESTRE MARINHO

\title{
PRINCÍPIO DA AUTORRESPONSABILIDADE NO DIREITO PENAL
}

\begin{abstract}
Dissertação apresentada como exigência parcial à obtenção do título de Mestre em Direito, no âmbito do Programa de Pós-Graduação da Faculdade de Direito da Universidade de São Paulo, inserido na área de concentração Direito Penal, Medicina Forense $e$ Criminologia, sob orientação do Professor Titular Miguel Reale Júnior.
\end{abstract}

FACULDADE DE DIREITO DA USP

SÃO PAULO

2013 
BANCA EXAMINADORA:

Orientador:

Professor Titular Miguel Reale Júnior

Professor Argüidor:

Professor Argüidor: 
À SOPHIA E AOS MEUS PAIS. 


\section{AGRADECIMENTOS}

A realização de um trabalho científico sério não seria possível sem o apoio inestimável de diversas instituições e de pessoas especiais.

Gostaria de agradecer à Faculdade de Direito da Universidade de São Paulo (USP), verdadeiro centro de excelência no que se refere à produção científica em Direito Penal, por propiciar todas as condições para o alcance do objetivo final.

Ao Instituto Brasileiro de Ciências Criminais (IBCCRIM), pela imensurável contribuição através de seu imponente acervo de produção científica e de sua fabulosa biblioteca.

Ao professor Miguel Reale Júnior, meu caro orientador, pela oportunidade de convívio e aprendizado inesquecíveis, pelas fundamentais palavras de incentivo e de encorajamento, e, acima de tudo, por apostar nas ideias e na ousadia de um jovem penalista.

À Sophia, companheira de todos os momentos, fiel incentivadora desde os bancos da graduação na UFMG, por encher a minha vida de alegria e por todo o suporte e carinho oferecidos ao longo desses anos.

Aos meus pais e ao meu irmão Rodrigo, pelo apoio incondicional de sempre e por batalharem junto comigo para a realização dos meus objetivos e sonhos.

Ao colega e amigo Douglas Ibarra, pela parceria e pelos longos debates acerca do Direito Penal.

E, por fim, a todos os professores, colegas, amigos, e funcionários que, de alguma forma, contribuíram para a realização desse trabalho. 


\section{RESUMO}

O presente estudo busca definir e afirmar o princípio da autorresponsabilidade como norma constitucional, decorrente do modelo de Estado Democrático de Direito, e, a partir daí, considerando o sistema de vinculação normativa propugnado pelo Estado Constitucional de Direito, avaliar criticamente a legitimidade da atuação paternalista estatal por meio do poder punitivo penal. Para tanto, primeiramente, busca-se traçar os parâmetros básicos do sistema jurídico-normativo, por meio de breves considerações acerca da teoria dos princípios. Em seguida, o objetivo é analisar a evolução do modelo de Estado, chegando-se ao atual Estado Constitucional e Democrático de Direito, desenhandose a forma como se coloca a relação entre Estado, Constituição e Direito Penal. No momento seguinte, parte-se, propriamente, para a afirmação e definição do princípio constitucional da autorresponsabilidade, inerente à adoção do modelo de Estado Democrático de Direito. Por fim, com amparo no modelo de Estado Constitucional de Direito, será estudado o impacto da aplicação do princípio da autorresponsabilidade no Direito Penal, começando-se pela análise dos tipos penais paternalistas, passando-se pela teoria do consentimento, e chegando-se à teoria da imputação do resultado.

Palavras-chaves: Direito Penal - Estado Democrático de Direito - Estado do Constitucional de Direito - Estado Constitucional e Democrático de Direito - Princípios Constitucionais - Princípio da Autorresponsabilidade - Paternalismo - Paternalismo Jurídico-Penal - Tipos Penais Paternalistas - Teoria do Consentimento - Teoria da Imputação do Resultado 


\section{RIASSUNTO}

Il presente studio mira a definire e sostenere il principio dell'autoresponsabilità come norma costituzionale derivata dal modello dello Stato Democratico di Diritto, e, a partire da ciò, valutare criticamente la legittimità dell'azione paternalista statale mediante il potere punitivo penale, considerando il sistema di vincolazione normativa propugnato dallo Stato Costituzionale di Diritto. A questo fine, in primo luogo si cercherà di tracciare $\mathrm{i}$ parametri di base del sistema giuridico-normativo tramite brevi considerazioni circa la teoria dei principi. Successivamente, l'obbiettivo sarà quello di analizzare l'evoluzione del modello di Stato, per arrivare all'attuale Stato Democratico Costiruzionale di Diritto, illustrando la relazione tra lo Stato, la Costituzione e il Diritto Penale. In seguito, ci si occuperà propriamente dell'affermazione e della definizione del principio costituzionale dell'autoresponsabilità, inerente all'adozione del modello di Stato Democratico di Diritto. Infine, in base al modello di Stato Costituzionale di Diritto, si studierà l'impatto dell'applicazione del principio dell'autoresponsabilità sul Diritto Penale, cominciando con l'analisi di fattispecie penali paternalistiche, passando poi alla teoria del consenso e arrivando per ultimo alla teoria dell'imputazione dell'evento.

Parole-chiave: Diritto Penale - Stato Democratico di Diritto - Stato Costituzionale di Diritto - Stato Democratico Costituzionale di Diritto - Principi Costituzionali - Principio dell'Autoresponsabilità - Paternalismo Paternalismo Giuridico-Penale - Fattispecie Penali Paternalistiche - Teoria del Consenso - Teoria della Imputazione dell'Evento 


\section{SUMÁRIO}

INTRODUÇÃ̃O 8

1. BREVES CONSIDERAÇÕES ACERCA DA TEORIA DOS PRINCÍPIOS 11

2. ESTADO, CONSTITUIÇÃO E DIREITO PENAL ........................................................ 19

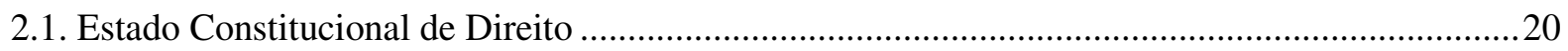

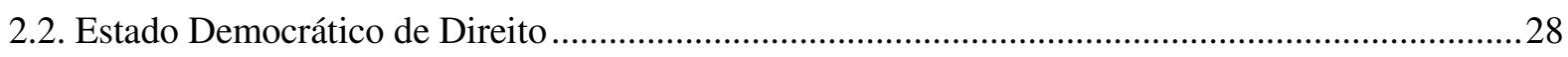

2.3. Estado Constitucional e Democrático de Direito e Direito Penal ..................................................... 34

3. PRINCÍPIO DA AUTORRESPONSABILIDADE ............................................................46

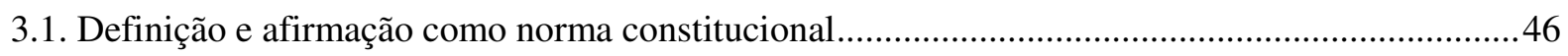

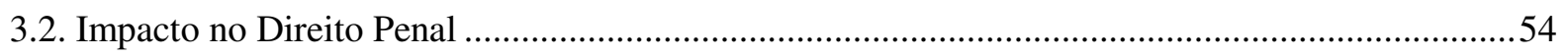

4. PRINCÍPIO DA AUTORRESPONSABILIDADE E TIPOS PENAIS

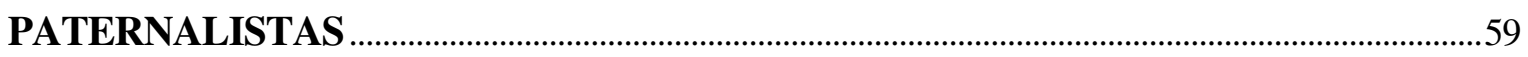

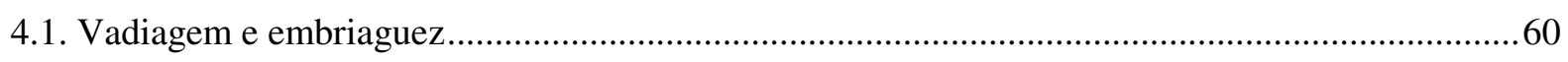

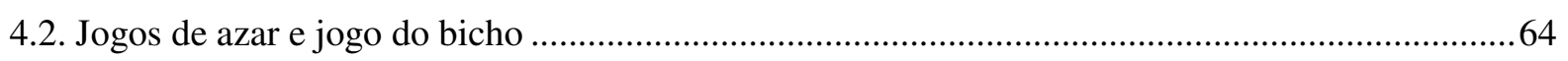

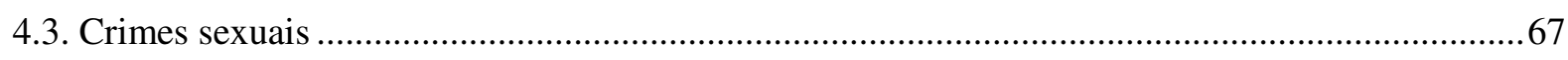

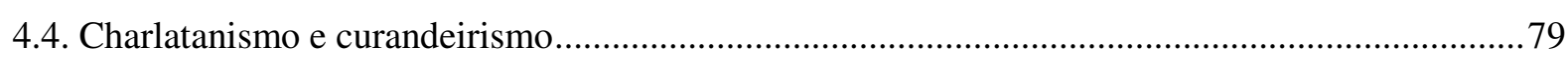

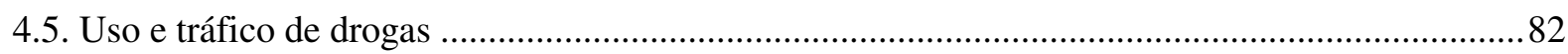

4.6. Comércio de tecidos, órgãos ou partes do corpo humano............................................................91

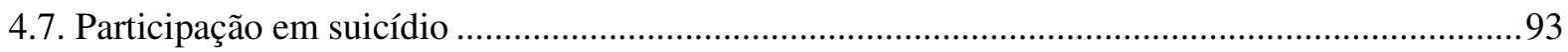

5. PRINCÍPIO DA AUTORRESPONSABILIDADE E TEORIA DO

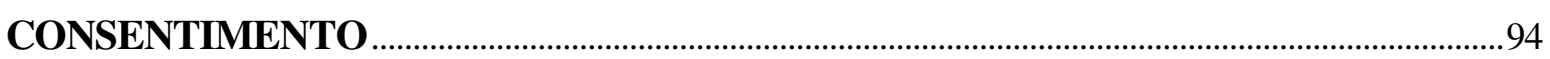

5.1. Vida e consentimento: participação em suicídio, eutanásia e homicídio a pedido .........................99

6. PRINCÍPIO DA AUTORRESPONSABILIDADE E TEORIA DA IMPUTAÇÃO DO

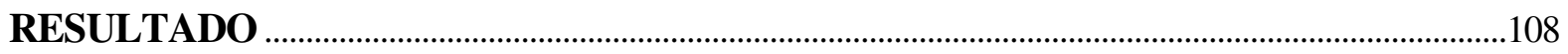

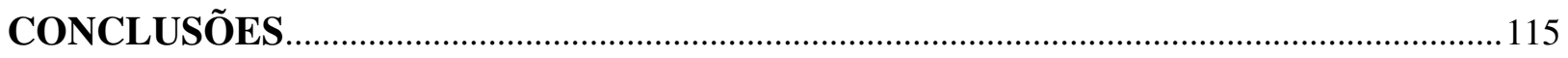

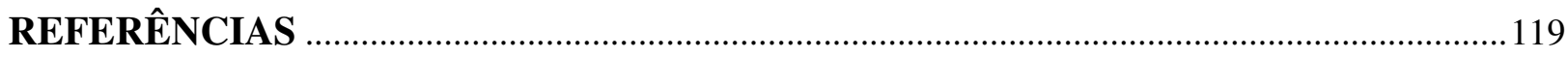




\section{INTRODUÇÃO}

O passar dos séculos, a ocorrência de importantes processos revolucionários, o desenvolvimento de todas as ciências, nada disso parece ter impedido que se chegasse ao presente século com um cenário de intensa interferência do Estado na esfera individual da pessoa.

Em pleno século XXI, o que se observa, talvez de forma cada vez mais frequente e abrangente, é o Estado tratando todos seus cidadãos como se crianças fossem, como seres acríticos e incapazes de tomar suas próprias decisões ou de estabelecer a sua própria forma de vida, muitas vezes numa tentativa incessante de afirmar padrões de condutas moralmente dominantes ou conforme os "bons costumes", ainda fortemente influenciado por preceitos religiosos.

Não há dúvidas de que se está diante de um Estado extremamente paternalista, que busca, de todas as formas, interferir na vida privada dos cidadãos, supostamente protegendo-os mesmo contra a sua vontade, vilipendiando o mais básico dos direitos, o direito à liberdade individual. Como exemplos, pode-se citar o cerco à prostituição, a proibição da venda de medicamentos para emagrecimento ou para ganho de massa muscular, a supertributação para desmotivar o consumo de tabaco, ou a obrigação de casamento em regime de separação total de bens quando um dos cônjuges tiver ultrapassado os 70 anos de idade. Com o avanço da neurociência, não seria exagero imaginar o Estado, daqui a algumas décadas, tentando proibir determinados tipos de pensamentos humanos.

A situação se torna ainda mais grave quando se constata que o Estado busca implementar a sua atuação paternalista utilizando-se de seu instrumento mais violento, qual seja, o seu poder punitivo penal. Para isso, eleva-se à condição de crime diversas condutas que não lesionam qualquer bem jurídico ou que, no máximo, lesionam apenas o bem jurídico do próprio indivíduo sobre qual o Estado pretende fazer incidir seu poder, criando, assim, verdadeiras infrações penais sem vítimas. Além disso, vale-se de uma teoria do delito que ignora a vontade do titular do bem jurídico passível de lesão, expandindo o seu poder punitivo e reafirmando o seu caráter paternalista. Busca-se, assim, muitas vezes, a todo 
custo, também por meio do poder punitivo, estabelecer-se padrões de condutas alinhados a uma suposta moral dominante, ignorando a liberdade individual.

O presente trabalho visa demonstrar que, no atual modelo de Estado Constitucional e Democrático de Direito, adotado pelo Brasil na Constituição de 1988, a atuação paternalista estatal por meio de seu poder punitivo penal carece de legitimidade, sobretudo diante do princípio constitucional da autorresponsabilidade, norma segundo a qual cada indivíduo se coloca como o único responsável por suas condutas, por suas escolhas, por sua forma de viver, desenvolvendo livremente a sua personalidade, no pleno exercício de sua autonomia.

Para tanto, como uma espécie de pré-requisito para o estudo de qualquer princípio jurídico, inicia-se com algumas breves considerações acerca da teoria dos princípios, buscando-se traçar os parâmetros básicos do sistema jurídico-normativo vigente.

Em seguida, parte-se para a análise da relação entre Estado, Constituição e Direito Penal, desenhando a evolução do modelo de Estado até se chegar ao atual Estado Constitucional e Democrático de Direito, e destacando-se como se coloca o Direito Penal nesse cenário.

No momento seguinte, o objetivo é definir e afirmar o princípio da autorresponsabilidade como norma constitucional diretamente decorrente do modelo de Estado Democrático, para, logo após, tendo em vista o sistema de vinculação normativa do Estado Constitucional, avaliar qual o impacto deste princípio no Direito Penal.

Seguindo esta linha, primeiramente, serão estudados os principais tipos penais paternalistas existentes no cenário jurídico brasileiro, avaliando-se a sua legitimidade diante do princípio constitucional da autorresponsabilidade.

No âmbito da dogmática penal, será analisado o impacto do princípio da autorresponsabilidade na teoria do consentimento assim como na teoria da imputação do resultado, as quais, de um modo geral, permanecem sendo estruturadas de modo a admitir a intervenção paternalista do poder punitivo, ignorando os preceitos do atual modelo de Estado.

Pode-se dizer, assim, que o trabalho desenvolve-se em quatro partes principais: apontamentos sobre o vigente sistema jurídico-normativo (cap.1); delimitação do atual modelo de Estado (cap.2); afirmação e definição do princípio da autorresponsabilidade 
como decorrência direta desse modelo de Estado (cap.3); e, por fim, análise do impacto da aplicação deste princípio no Direito Penal (Cap.4, 5 e 6).

Como se poderá perceber, trata-se de um trabalho em defesa da liberdade individual frente a intervenções ilegítimas do Estado, baseado não apenas em qualquer argumento de interesse ou conveniência, mas, fundamentalmente, no pacto firmado em 1988.

O compromisso científico conduziu à necessidade de manifestação sobre temas extremamente delicados, alguns considerados verdadeiros tabus, tais como o referente ao uso e tráfico de drogas, ao comércio de órgãos humanos, e à disponibilidade da vida humana. $\mathrm{O}$ enfrentamento de tais questões, mesmo em uma Dissertação de Mestrado, só foi possível graças ao suporte inestimável oferecido por um orientador da envergadura do professor Miguel Reale Júnior, professor no sentido mais belo e completo da palavra, e, também, devido às condições oferecidas pela Faculdade de Direito da Universidade de São Paulo, locus - por excelência - de estudo, discussão e questionamento do cenário jurídico vigente.

De qualquer modo, espera-se que, ainda que levando em conta as limitações inerentes a qualquer trabalho científico, que sempre pressupõe um recorte metodológico, este trabalho possa representar uma reflexão da qual não mais se pode esquivar, qual seja, sobre a (i) legitimidade da atuação paternalista do Estado por meio de seu poder punitivo. Advirta-se, desde já, todavia, que, por razões metodológicas, não integrará o objeto do trabalho a discussão acerca de legitimidade da intervenção penal em situações que envolvem pessoas consideradas com capacidade de discernimento reduzida ou inexistente, a exemplo dos menores de 18 anos de idade e dos deficientes mentais. A atuação paternalista do poder punitivo estatal sobre indivíduos adultos e plenamente responsáveis, este o objeto do presente trabalho. 


\section{BREVES CONSIDERAÇÕES ACERCA DA TEORIA DOS PRINCÍPIOS}

A afirmação e o estudo de um princípio jurídico e de sua repercussão no Direito Penal exige um mínimo de conhecimento acerca de uma Teoria Geral dos Princípios, até mesmo para que se possa estabelecer as bases sobre as quais se desenvolverá o trabalho. Assim como se mostra importante, por exemplo, estudar os preceitos de uma Teoria da Constituição antes de se aprofundar em um tema específico de Direito Constitucional, ou, ainda, os fundamentos de uma Teoria da História anteriormente ao estudo da História do Direito Penal brasileiro, parece fundamental o estudo, ainda que breve, da chamada Teoria dos Princípios como ponto de partida para análise aprofundada de determinado princípio jurídico.

Importante pontuar, nesse sentido, que as indagações acerca de uma proposta conceitual dos princípios, da delimitação de suas funções, da diferenciação em relação às regras e de suas possibilidades e condições de aplicabilidade e eficácia, apresentam-se, como um dos objetos centrais da própria Teoria do Direito e, mais recentemente, da Teoria do Direito Constitucional e da Teoria dos Direito Fundamentais, objeto, portanto, de inúmeros debates doutrinários e jurisprudenciais contemporâneos ${ }^{1}$.

A despeito da diversidade das elaborações doutrinárias e jurisprudenciais em torno de uma complexa Teoria dos Princípios, para o escopo do presente trabalho mostrase suficiente e recomendável apenas a fixação de algumas premissas fundamentais, o que, inevitavelmente, conduzirá a adoção de um modelo normativo sobre o qual se apoiará a parte principal deste trabalho.

\footnotetext{
${ }^{1}$ Humberto Ávila lembra "ser plausível afirmar que a doutrina constitucional vive, hoje, a euforia do que se convencionou chamar de Estado Principiológico." (Teoria dos princípios. 10. ed. São Paulo: Malheiros Ed., 2009. p. 23).
} 


\section{A) Definição}

Princípio jurídico é norma jurídica ${ }^{2}$, entendida esta, numa perspectiva semântica, como o significado de um enunciado normativo ${ }^{3}$ ou, ainda, como o sentido construído a partir da interpretação sistemática de um texto normativo ${ }^{4}$.

Assim, desde logo, fica patente a diferença entre norma e dispositivo. Há norma sem dispositivo e dispositivo sem norma. No ordenamento jurídico brasileiro, por exemplo, qual dispositivo prevê o princípio da segurança jurídica? Nenhum. E qual norma pode ser construída a partir do enunciado constitucional que prevê a proteção de Deus $?^{5}$ Nenhuma.

A partir de um único dispositivo podem ser extraídas várias normas. Do dispositivo que prevê que não há crime sem lei anterior que o defina nem pena sem prévia cominação legal (CF, art.5 $5^{\circ}$ XXIX), por exemplo, pode-se extrair as normas da segurança jurídica, da legalidade, da tipicidade penal, da proibição da analogia, da proibição da delegação normativa etc. De igual forma, vários dispositivos podem originar uma única norma. Dos enunciados do art. $5^{\circ}$ LVI, da CF, e do art. 157, caput, do CPP, extrai-se a norma da inadmissibilidade das provas ilícitas no processo penal.

O importante, pois, é saber que não há identidade entre norma e dispositivo, e que um pode perfeitamente existir sem o outro ${ }^{6}$, podendo-se afirmar, portanto, a existência de normas explícitas - expressas diretamente em dispositivo específico - e implícitas extraídas, indiretamente, da leitura de dispositivos diversos e do próprio sistema jurídico no qual se insere. Fixada essa premissa, pode-se partir para a construção de uma definição precisa de princípio jurídico.

Princípio jurídico, na perspectiva aqui adotada, é norma jurídica que ordena que algo seja realizado na maior medida possível, dentro das possibilidades jurídicas e fáticas existentes. Afigura-se, assim, como mandamento de otimização, podendo ser satisfeito

\footnotetext{
${ }^{2}$ Vale-se, aqui, do termo "jurídico" para restringir as expressões "princípio" e "norma" à Ciência do Direito, tendo em vista a frequente utilização tanto inserida na linguagem coloquial quanto por outras diversas ciências, como por exemplo, a Sociologia e a Filosofia. Neste trabalho, a partir deste ponto, sempre que se utilizar o termo "princípio" estará referindo-se a "princípio jurídico", salvo menção expressa em contrário.

${ }^{3}$ ALEXY, Robert. Teoria dos direitos fundamentais. São Paulo: Malheiros Ed., 2008. p. 54.

${ }^{4}$ ÁVILA, Humberto. op. cit., p. 30.

${ }^{5}$ Id., loc. cit.

${ }^{6}$ Id. Ibid., p. 31.
} 
em graus variáveis, em razão do contexto fático e da possível colisão com outras normas $^{7}$.

\section{B) Princípios e regras}

Outra espécie de norma jurídica é a regra jurídica, sendo muitos os critérios elaborados pela doutrina para distingui-la do princípio, os quais acabam contribuindo para uma mais completa compreensão deste ${ }^{8}$.

Muitos autores afirmam que o que difere as duas espécies de normas é apenas o grau de importância ou de abstração. Assim, há quem diga que os princípios seriam as normas mais importantes, verdadeiros fundamentos do ordenamento jurídico, enquanto as regras se caracterizariam por ser meras concretizações de tais princípios. E existem aqueles que ressaltam estar a principal diferença no maior grau de abstração dos princípios, os quais, ao contrário das regras, não estariam a se reportar a nenhuma descrição de situação fática em específico, assumindo um caráter de máxima abstratividade ${ }^{9}$.

Embora sem negar alguma validade às posições anteriores, a posição aqui seguida será aquela no sentido de haver, na realidade, uma diferença principal qualitativa entre princípios e regras. Enquanto os princípios são, como visto, mandamentos de otimização aplicáveis ou não conforme a realidade fática e jurídica, as regras se afiguram como determinações que são sempre ou satisfeitas ou não satisfeitas, sob pena de carência de validade ${ }^{10}$.

\footnotetext{
${ }^{7}$ Concepção de Robert Alexy (op. cit., p. 90). Adotada, p. ex., por José Joaquim Gomes Canotilho (Direito constitucional. Coimbra: Almedina, 2003. p. 1161) e Virgilio Afonso da Silva (Direitos fundamentais. São Paulo: Malheiros Ed., 2010. p. 46). Para uma concepção similar, cf.: DWORKIN, Ronald. Levando os direitos a sério. São Paulo: Martins Fontes, 2010. p. 35 e seg. Para uma proposta diferenciada, cf.: ÁVILA, Humberto. op. cit., p. 64 e seg.

${ }^{8}$ Para uma visão panorâmica e crítica do diversos critérios de diferenciação, com referências bibliográficas (ÁVILA, Humberto. op. cit., p. 35-52 e CANOTILHO, J. J Gomes. op. cit., p. 1160-1162) Há autores que renegam o enquadramento de princípios e regras como espécie de normas (cf., p. ex., SILVA, José Afonso da. Curso de direito constitucional positivo. 33. ed. São Paulo: Malheiros Ed., 2009. p. 91 e seg; BANDEIRA DE MELLO, Celso Antônio. Curso de direito administrativo. 25. ed. São Paulo: Malheiros Ed., 2008. p. 53).

${ }^{9}$ Nesse sentido, TAVARES, André Ramos. Princípios constitucionais. In: MARTINS, Ives Gandra da Silva; MENDES, Gilmar Ferreira; NASCIMENTO, Carlos Valder do (Orgs.). Tratado de direito constitucional. São Paulo: Saraiva, 2010. v. 1, p. 406.

${ }^{10}$ ALEXY, Robert. op. cit., p. 90-91. No mesmo sentido CANOTILHO, J. J Gomes. op. cit., p. 1160-1162 e SILVA, Virgílio Afonso da. op. cit., p. 44-46. Diversamente, ÁVILA, Humberto. op. cit., 78-84.
} 
Dessa forma, pode-se afirmar que princípios são normas que impõem deveres ou garantem direitos prima facie, ao contrário das regras, as quais impõem deveres ou garantem direitos definitivos. ${ }^{11}$ Isso quer dizer que o direito assegurado em uma regra deve ser realizado totalmente, caso se conclua pela sua aplicabilidade, ressalvando, é claro, as hipóteses de exceção. No caso dos princípios, isso não acontece. Diante do caso concreto, um princípio inicialmente (ou aparentemente) relevante para oferecer a solução, pode ser realizado de forma apenas parcial, considerando a realidade fática e jurídica.

Além disso, importante pontuar também uma importante diferença de conteúdo entre princípios e regras: enquanto os primeiros normalmente identificam valores a serem preservados ou finalidades a serem perseguidas (caráter valorativo ou finalístico), as segundas geralmente limitam-se a descrever condutas (caráter descritivo). ${ }^{12}$

No âmbito deste trabalho, interessa observar que os tipos penais são regras por excelência, descrevendo condutas proibidas e expressando um mandamento de dever ser, sob pena de uma sanção criminal.

\section{C) Conflitos normativos}

Outro tema bastante discutido - e que também tem o condão de diferenciar princípios e regras - refere-se aos conflitos entre normas. Uma vez mais, importante consignar que não se pretende, nos limites do presente trabalho, aprofundar-se em discussões ou polêmicas envolvendo tópicos da Teoria dos Princípios, bastando apenas estabelecer as bases sobre as quais se desenvolverá o estudo.

Fundamental, neste ponto, é traçar os parâmetros básicos que devem orientar a busca de uma solução nos diferentes casos de conflito normativo, definido estes como situações nas quais há incompatibilidade - parcial ou total - entre normas. Tal incompatibilidade pode se verificar já no plano abstrato ou somente diante de uma situação concreta. Assim, importante consignar que normas podem perfeitamente conviver no plano abstrato, mas concretamente entrar em conflito.

\footnotetext{
${ }^{11}$ ALEXY, Robert. op. cit., p. 103-106. CANOTILHO, J. J Gomes. op. cit., p. 1160-1162. SILVA, Virgílio Afonso da. op. cit., p. 45-46.

${ }^{12}$ BARROSO, Luís Roberto. Interpretação e aplicação da Constituição: fundamentos de uma dogmática constitucional transformadora. 7. ed. São Paulo: Saraiva, 2009. p. 355.
} 
O conflito abstrato pode ser solucionado pelo legislador - com a edição ou revogação de dispositivos normativos - ou pelo Judiciário - por meio do procedimento de controle abstrato de constitucionalidade, no caso de conflito com regras ou princípios estabelecidos na Constituição ${ }^{13}$.

Já o conflito normativo concreto ocorre sempre diante de um caso específico levado ao Judiciário, demandando, portanto, solução a ser oferecida pelo julgador.

Tais conflitos podem acontecer entre regras, entre princípios ou entre princípios e regras.

O conflito entre regras é solucionado através do famoso mecanismo "tudo ou nada" ${ }^{14}$, pelo qual não se admite aplicação parcial ou mitigada. Se os fatos previstos numa regra ocorrem, ela deverá incidir, a não ser que seja considerada inválida, que haja outra regra mais específica, ou que não esteja mais em vigor ${ }^{15}$.

Dessa forma, a decisão sobre qual regra deve ser aplicada geralmente é tomada com base em critérios de hierarquia, especialidade ou cronologia ${ }^{16} \cdot$, resultando sempre no afastamento de uma regra e na aplicação de outra.

Um exemplo de conflito entre regras no Brasil verificou-se entre parte do art.32 da Lei de Contravenções Penais (Decreto-Lei 3.688/41) e os artigos 162 e 309 do Código de Trânsito Brasileiro (CTB - Lei $n^{\circ}$ 9.503/97). A conduta de dirigir veículo, em via pública, sem habilitação, passou a ser inteiramente disciplinada por lei especial posterior, que a considerou infração administrativa gravíssima e, acrescentando o elemento "gerando perigo de dano", a elevou a condição de crime. Nesse conflito, valendo-se do critério da especialidade, prevaleceram as normas do CTB, com a revogação tácita parcial do art.32 da $\mathrm{LCP}^{17}$.

O conflito entre princípios, diferentemente, é solucionado por critérios de prevalência, em uma análise acerca da dimensão do peso, sendo que a aplicação de um em detrimento de outro, em uma situação concreta, não afasta a validade daquele não

\footnotetext{
${ }^{13}$ Para uma visão completa do sistema de controle de constitucionalidade, cf. MENDES, Gilmar Ferreira et al. Curso de direito constitucional. São Paulo: Saraiva: 2008. p. 999 e seg.

${ }^{14}$ DWORKIN, Ronald. op. cit., p. 39. ALEXY, Robert. op. cit., p. 92-93. Para uma visão crítica, cf.: ÁVILA, Humberto. op. cit., p. 52-64. Contra-crítica em: SILVA, Virgílio Afonso da. op. cit., p. 56-64.

${ }^{15}$ BARROSO, Luís Roberto. op. cit., p. 356.

${ }^{16}$ ALEXY, Robert. op. cit., p. 93. DWORKIN, Ronald. op. cit., p. 43.

${ }^{17}$ Conflito manifestado em casos concretos levados ao Judiciário. Cf., p. ex., STJ - RHC 8151/SP. Rel. Min. Luiz Vicente Cernicchiaro. j.02/02/1999.
} 
aplicado. Em outra situação, este princípio anteriormente afastado pode ter prevalência sobre o mesmo princípio que houvera sido aplicado ${ }^{18}$. Trata-se de um raciocínio de sopesamento ou de um processo de ponderação ${ }^{19}$.

Assim, enquanto as regras se excluem quando em conflito, os princípios se harmonizam, sendo possível a aplicação em graus variados.

Um exemplo de conflito freqüente é o que envolve o princípio da liberdade e imprensa e o princípio que garante o direito à imagem e à privacidade. Em cada caso concreto, um terá prevalência sobre o outro ${ }^{20}$.

É claro que essa forma de solução de conflitos só assume relevância quando se tratar de princípios situados no mesmo grau hierárquico dentro do ordenamento jurídico. O eventual conflito entre um princípio constitucional e um princípio infraconstitucional, por exemplo, conduz, logicamente, à aplicação do primeiro, podendo, inclusive, acarretar a invalidade do segundo.

Pode ocorrer, ainda, um embate entre princípios e regras, que, de um modo geral, também pode ser resolvido através de um processo de sopesamento, o qual ocorre, na realidade, entre o princípio colidente e o princípio no qual a regra se baseia ${ }^{21}$. Esse tipo de conflito é muito comum entre princípios constitucionais e regras infraconstitucionais, ensejando uma decisão acerca da (in)constitucionalidade da regra.

Em muitos desses casos, porém, a regra infraconstitucional não apresenta qualquer princípio que lhe forneça amparo constitucional direto, o que acarreta o reconhecimento de sua inconstitucionalidade sem a necessidade de sopesamento entre princípios.

Isso ocorreu, por exemplo, no contexto da declaração de inconstitucionalidade da regra que vedava a progressão de regime prisional nos casos de crimes hediondos. Nessa oportunidade, ficou consignado que a regra

\footnotetext{
${ }^{18}$ ALEXY, Robert. op. cit., p. 93-94. DWORKIN, Ronald. op. cit., p. 42.

${ }^{19}$ BARROSO, Luís Roberto. op. cit., p. 357.

${ }^{20}$ Para se determinar qual princípio deve ser aplicado em caso concreto, fala-se no estabelecimento de relações condicionadas de precedência. Cf., detalhadamente, ALEXY, Robert. op. cit., p. 94 e seg. $e$ SILVA, Virgílio Afonso da. op. cit., p. 50.

${ }^{21}$ ALEXY, Robert. op. cit., p. 90 .nota 24. Para uma visão crítica: SILVA, Virgílio Afonso da. op. cit., p. 51-56.
} 
violava o princípio constitucional da individualização da pena, princípio este para o qual a Constituição não ampara exceções ${ }^{22}$.

Outro exemplo de regra reconhecidamente inconstitucional por violação a princípio disposto na Constituição é aquela expressa no revogado art.594 do Código de Processo Penal, a qual obrigava o recolhimento em prisão para o conhecimento da apelação contra sentença condenatória. O conflito, aqui, se estabeleceu com o princípio da presunção de inocência, explicitado no art. $5^{\circ}$, inciso LVII, da Constituição.

O presente trabalho, conforme se verá, especialmente em seu capítulo 4, tratará da existência de inúmeros conflitos entre uma regra legal - tipos penais - e um princípio de hierarquia constitucional, qual seja, o princípio da autorresponsabilidade.

\section{D) Funções, aplicabilidade e eficácia dos princípios}

Os princípios, como toda norma jurídica, possuem a função primordial de expressar um mandamento de dever-ser ${ }^{23}$. Ao expressar valores ou indicar fins a serem perseguidos, irradiam-se pelo sistema, interagem entre si e pautam principalmente a atuação dos órgãos de poder, em todas as esferas ${ }^{24}$.

A aplicação desse mandamento pode se dar de forma direta - quando a sua aplicação e produção de efeitos ocorre sem intermediação - ou indireta - quando ocorre com a intermediação de outro (sub)princípio ${ }^{25}$ ou regra $^{26}$.

Diretamente, em nível abstrato, um princípio pode levar à declaração de inconstitucionalidade de uma regra ou orientar o legislador na elaboração de tipos penais ou de normas de incidência tributária, por exemplo, mas também pode, em nível concreto, servir como razão para decisões individualizadas ${ }^{27}$.

\footnotetext{
${ }^{22}$ STF - HC 82.959/SP. Rel. Min. Marco Aurélio. 23/02/2006.

${ }^{23}$ ALEXY, Robert. op. cit., p. 58.

${ }^{24}$ BARROSO, Luís Roberto. op. cit., p. 376.

${ }^{25}$ Acerca da relação entre princípio e subprincípio, em nível constitucional, cf. CANOTILHO, J. J Gomes. op. cit., p. 1173-1175.

${ }^{26}$ ÁVILA, Humberto. op. cit., p. 97.

${ }^{27}$ Nesse sentido: ALEXY, Robert. op. cit., p. 107 , ÁVILA, Humberto. op. cit., p. 97 e seg., CANOTILHO, J. J Gomes. op. cit., p. 1178 e seg. Em sentido contrário, entendendo que os princípios atuam somente indiretamente: TAVARES, André Ramos. op. cit., v. 1, p. 406. Tal entendimento, ao menos em nível constitucional, parece ignorar a norma do art. $5^{\circ}, \S 1^{\circ}$, da Constituição Federal.
} 
De forma indireta, os princípios orientam a criação de subprincípios e regras, constituindo verdadeiros fundamentos dos diversos sistemas, afigurando-se também como elementos de interpretação, integração e delimitação de normas jurídicas.

Seguindo esta linha, de um modo geral, pode-se falar que os princípios possuem uma eficácia positiva, interpretativa e negativa ${ }^{28}$.

A eficácia positiva é aquela tradicionalmente atribuída às regras, e tem o condão de reconhecer àquele que seria beneficiado pela norma, ou simplesmente aquele que deveria ser atingido pela realização de seus efeitos, o direito subjetivo a esses efeitos.

A eficácia interpretativa, por sua vez, traduz a ideia de que se pode exigir do Judiciário que as normas de hierarquia inferior sejam interpretadas de acordo com as de hierarquia superior. Assim, por exemplo, atos regulamentares devem ser interpretados de acordo com princípios legais e leis ordinárias devem ser interpretadas à luz dos princípios constitucionais.

Por último, há também a eficácia negativa, a qual autoriza que sejam declaradas inválidas todas as normas ou atos que contravenham os efeitos pretendidos pela norma.

Com essas breves considerações, passa-se, agora, ao estudo da formatação do atual modelo de Estado, o que, acredita-se, evidenciará a importância dos princípios jurídicos nesse cenário, sobretudo como instrumento de limitação do poder punitivo estatal.

\footnotetext{
${ }^{28}$ Classificação proposta por Luís Roberto Barroso. O autor menciona, ainda, uma "eficácia vedativa do retrocesso" e esclarece que "eficácia é um atributo associado às normas e consiste na consequência jurídica que deve resultar de sua observância, podendo ser exigida judicialmente se necessário" (Interpretação $e$ aplicação da Constituição: fundamentos de uma dogmática constitucional transformadora, cit., p. 378-385).
} 


\section{ESTADO, CONSTITUIÇÃO E DIREITO PENAL}

O exercício do poder punitivo estatal é um fenômeno essencialmente político. A forma de exercício desse poder, a delimitação de sua eventual função, as suas características, a determinação das condutas que legitimam a sua atuação, a definição de seus limites, tudo isso depende diretamente da conformação política do Estado, que, sofrendo variações no tempo e no espaço, forma os chamados modelos de Estado ${ }^{29}$.

E, logicamente, a conformação política do Estado, normalmente apoiada nos valores fundamentais de cada sociedade, influencia a formação de sua estrutura normativa, determinando a criação do Direito, o surgimento de uma Constituição, e a formatação dos variados sistemas normativos, incluindo o referente ao Direito Penal.

Assim, qualquer estudo aprofundado acerca do Direito Penal deve ter como pressuposto o modelo de Estado objeto da reflexão ${ }^{30}$. Por essa razão, parte-se, nesse momento, para a afirmação e análise do modelo de Estado atualmente vigente no Brasil, qual seja, Estado Constitucional e Democrático de Direito, para, em seguida, avaliar qual o impacto de sua adoção no Direito Penal.

\footnotetext{
${ }^{29}$ Sobre o tema, cf., p. ex., PALAZZO, Francesco. Valores constitucionais e direito penal. Porto Alegre: Safe, 1989. p. 16-22. BECHARA, Ana Elisa Liberatore Silva. Da teoria do bem jurídico como critério de legitimidade do direito penal. Tese (Livre-Docência) - Faculdade de Direito da Universidade de São Paulo, 2011. p. 21-28. MIR PUIG, Santiago. Constitución, derecho penal y globalización. In: MIR PUIG, Santiago; CORCOY BIDASOLO, Mirentxu (Dir.); GÓMEZ MARTÍN, Víctor (Coord.). Nuevas tendencias en política criminal: una auditoría al Código Penal español de 1995. Montevidéu: B. de F. Julio César Faira, 2006. p. 115126. Id. La nueva constitución española y el derecho penal: fundamento constitucional de la pena y teoría del delito. Doctrina Penal: teoría y prática en las ciencias penales, Buenos Aires, v. 2, 5/8, p. 525-560, 1979.

30، Cada modelo de Estado exige una particular concepcíon del Derecho Penal y de su funcíon. (...). Si el modelo de Estado debe determinar una concepcíon del Derecho Penal, esta há de ofrecer soporte de su componentes básicos, la pena e el delito: Estado, Derecho Penal, pena y delito se hallan em uma estricta relacíon de dependência." (MIR PUIG, Santiago. Revisión de la teoría del delito en un estado social y democrático de derecho. In: BELLO RENGIFO, Carlos Simón; ROSALES, Elsie (Comp.). Libro homenaje a José Rafael Mendoza Troconis. Caracas: Instituto de Ciencias Penales y Criminológicas; Facultad de Ciencias Jurídicas y Políticas; Universidad Central de Venezuela, 1998. v. 2, p. 195-218).
} 


\subsection{Estado Constitucional de Direito}

“Ontem os códigos. Hoje a Constituição",31. Estas duas curtas frases resumem a transição - que vem ocorrendo, em nível internacional ${ }^{32}$, desde o período pós-segunda guerra mundial - de um modelo de Estado Legal de Direito para uma verdadeira concepção de Estado Constitucional de Direito ${ }^{33}{ }^{34}$. Mais do que isso: simbolizam a passagem para uma nova forma de constitucionalismo, na qual a Constituição assume efetivamente a posição de centro do sistema normativo.

Para compreender a atual formatação do Estado e do constitucionalismo, antes, porém, é preciso voltar um pouco mais no tempo, precisamente ao momento de formação dos Estados nacionais, sobretudo a partir do século XV.

A centralização do poder nas mãos de um governante, a unificação das fronteiras e o nascimento da ideia de Estado-nação, tudo isso significou a instauração de uma nova ordem, na qual o Estado (Moderno) passou a assumir a figura de protagonista absoluto, externa e internamente.

\footnotetext{
${ }^{31}$ As frases são de Paulo Bonavides, reproduzidas por Luís Roberto Barroso. (A Constituição Brasileira de 1988: uma introdução. In: MARTINS, Ives Gandra da Silva; MENDES, Gilmar Ferreira; NASCIMENTO, Carlos Valder do (Orgs.). Tratado de direito constitucional. São Paulo: Saraiva, 2010. v. 1, p. 38).

${ }^{32} \mathrm{Na}$ Europa, as principais referências são as Constituições da Itália (1947), da Alemanha (1949), de Portugal (1976) e da Espanha (1978).

${ }^{33}$ Expressão utilizada, p. ex., por Luigi Ferrajoli (Direito e razão: teoria do garantismo penal. 2. ed. São Paulo: Ed. Revista dos Tribunais, 2006. p. 325-338 e 785-833; Id. O Estado constitucional de direito hoje: o modelo e a sua discrepância com a realidade. Revista do Ministério Público de Lisboa, n. 67, v. 17, p. 3956, 1996; Id. Sobre el papel cívico y político de la ciencia penal en el Estado constitucional de derecho. Nueva Doctrina Penal, Buenos Aires, A, p. 63-71, 1998; Id. Pasado y futuro del Estado de derecho. In: CARBONELL, Miguel (Org.). Neoconstitucionalismo(s). 4. ed. Madrid: Trotta, 2009), J.J. Gomes Canotilho (Direito constitucional, cit., p. 92 e seg.), Francesco Palazzo (Estado constitucional de derecho y derecho penal. Revista Penal, n. 2, p. 49-60, 1998), Manuel García-Pelayo (Estado legal e Estado constitucional de derecho. Revista de la Facultad de Ciencias Jurídicas y Políticas, Caracas, n. 82, p. 32-45, 1991) Marino Barbero Santos (Estado constitucional de derecho y sistema penal. Direito e Cidadania, Praia, Cabo Verde, v. 3, p. 13-24, jul./fev. 2000/2001), Eugênio Raúl Zaffaroni e Nilo Batista (Direito penal brasileiro. Rio de Janeiro: Revan, 2003. v. 1), Eugênio Raúl Zaffaroni ( $O$ inimigo no direito penal. 2. ed. Rio de Janeiro: Revan, 2007) Luiz Regis Prado (Bem jurídico-penal e Constituição. São Paulo: Ed. Revista dos Tribunais, 2009. p. 61-73) e Luciano Feldens (A Constituição penal: a dupla face da proporcionalidade no controle de normas penais. Porto Alegre: Livr. do Advogado, 2005; Id. A conformação constitucional do direito penal. In: WUNDERLICH, Alexandre (Coord.). Política criminal contemporânea: criminologia, direito penal e direito processual penal: homenagem do Departamento de Direito Penal e Processual Penal pelos 60 anos da Faculdade de Direito da PUC/RS. Porto Alegre: Livr. do Advogado, 2008).

${ }^{34}$ Conforme se verá abaixo, na linha da advertência feita por Luciano Feldens (A Constituição penal: a dupla face da proporcionalidade no controle de normas penais, cit., p. 29, nota 7), a referência aqui é ao modelo de Estado que vem se consolidando após a $2^{\text {a }}$ Guerra Mundial, não se confundindo com o modelo apenas formalmente constitucional surgido a partir do período revolucionário do séc. XVIII.
} 
No âmbito interno, o que se observou ao longo do período que se seguiu foi a utilização do Estado apenas para atender aos seus próprios interesses, a serviço de uma pequena classe aristocrática, em formas de estado absolutistas, com amparo nas principais concepções filosóficas da época ${ }^{35}$.

No modelo de Estado absoluto, a autoridade (monarca, rei, imperador, inca) determina as normas e a estrutura de poder. Assim, o poder se encontra concentrado em uma única pessoa ou classe política, de forma ilimitada, e não existem procedimentos para fazer a lei e nem tampouco para aplicá-la de forma a evitar a arbitrariedade ${ }^{36}$.

Para o escopo e nos limites do presente trabalho, interessa dizer, de forma bastante simplificada, que o poder punitivo estatal, ao menos da forma como se concebe hoje, nasce com o próprio surgimento desse modelo de Estado nacional, sendo quase que uma decorrência natural da criação dessa entidade abstrata ${ }^{37}$. Afirma-se, nesta linha, que a essência do Direito Penal nasce com a assunção, por parte do Estado, do poder de punir, subtraindo-o da disponibilidade das partes privadas ${ }^{38}$.

A própria ideia de contrato social ${ }^{39}$, sobre a qual se apoia o modelo de Estado nacional, ao defender a cessão de parcela da liberdade de cada indivíduo ao Estado, acaba por transferir a este um poder de punir, monopolizado, em nome dos interesses do Estado-nação.

Mudanças no cenário econômico, industrialização, insatisfação com as arbitrariedades e com os excessivos privilégios concedidos a uma decadente classe

\footnotetext{
${ }^{35}$ São apontados como os principais "teóricos do absolutismo": Nicoló Machiavelli (O príncipe, 1532), Thomas Hobbes (Leviatã, 1651) e Jean Bodin (Os Seis Livros da República, 1576).

${ }^{36}$ ÁVILA SANTAMARÍA, Ramiro. Del Estado legal de derecho al Estado constitucional de derechos y justicia. In: ELSNER, Gisela (Ed.). Anuario de derecho constitucional latinoamericano 2009. 15. ed. Montevidéu: Konrad-Adenauer-Stiftung, 2009. p. 775-793.

${ }^{37}$ Gilmar Mendes destaca, citando Max Weber, que o exercício do monopólio da violência física legítima é um fator necessário à própria existência do Estado Moderno (Curso de direito constitucional, cit., p. 40-41).

${ }^{38}$ DI GIOVINE, Ombreta. Il contributo della vittima nel delitto colposo. Torino: Giappichelli, 2003. p. 4. Para uma visão histórica mais abrangente e diferenciada, cf. ZAFFARONI, Eugenio Raúl; BATISTA, Nilo. Direito penal brasileiro, cit., v. 1, p. 383-410. "A formação das nações, na época moderna, constitui um fato histórico decorrente de inúmeros fatores, e que varia segundo as particulares circunstâncias de cada uma delas, tento em comum, no entanto, o fato do progressivo centralismo do Poder Político.(...). Ao afirmar a positividade do próprio Direito, de modo originário, o Estado se põe como soberano, isto é, declara, em última instância, o Direito que regula a sociedade, ao mesmo tempo em que traz para si a função de dizer o direito no caso concreto, exercendo o monopólio da jurisdição. Desse maneira, passa o Estado a exercer o poder de legislar e de aplicar o direito, superando-se definitivamente o estágio da autorização da vindicta privada, bem como da composição entre a vítima ou seu familiares e o réu ou sua família mediante o pagamento da Wertgeld, como meio de recomposição da paz social" (REALE JÚNIOR, Miguel. Instituições de direito penal. 3. ed. São Paulo: Saraiva, 2009. p. 13-15).

${ }^{39}$ Sobre a teoria do contrato social, cf. ROSSEAU, Jean-Jaques. $O$ contrato social. São Paulo: Martins Fontes, 1999.
} 
aristocrata em detrimento de uma classe burguesa crescente, tudo isso contribuiu para a falência do modelo de Estado absoluto.

Em reação a este estado de coisas, coube, pois, ao movimento iluminista, a partir do século XVIII, a construção e o desenvolvimento de ideias de limitação do poder estatal - incluindo o poder punitivo -, fomentando o acontecimento de grandes modificações na estrutura do Estado, com destaque para a Revolução Francesa de $1789^{40}$.

Neste momento, seguindo a linha da Declaração de Direitos do Homem, originária do período revolucionário francês, também de 1789, aparecem os primeiros textos constitucionais, documentos essencialmente políticos, que se apresentam eminentemente como cartas de intenções, destituídas de caráter jurídiconormativo e sujeitas a processos facilitados de modificação ${ }^{41}$.

Surge, portanto, a figura do Estado de Direito, que submete o Estado ao Direito, a formas e procedimentos previamente definidos, instituindo-se mecanismos de limitação do poder, sendo este, normalmente, divido em Legislativo, Executivo e Judiciário ${ }^{42}$.

Em uma breve análise evolutiva do Estado pós-iluminismo, verifica-se que, em um primeiro momento, como efeito da afirmação do princípio da legalidade, constrói-se um modelo de Estado Legal de Direito ${ }^{43}$, ancorado na assunção do monopólio legislativo estatal. Trata-se do período conhecido como o do "império da lei", no qual todos, inclusive os poderes públicos, estão submetidos formalmente a ela. Verifica-se a prevalência quase absoluta do Poder Legislativo - que atua com ampla liberdade -, e opera-se a máxima montesquiana de que o juiz deve ser “a boca da lei”.

\footnotetext{
${ }^{40} \mathrm{~A}$ importante experiência do Estado inglês não será aqui tratada, pois esteve sempre ligada à tradição do common law. Da mesma forma: FERRAJOLI, Luigi. Pasado y futuro del Estado de derecho, cit., p. 14.

${ }^{41}$ FERRAJOLI, Luigi. Sobre el papel cívico y político de la ciencia penal en el Estado constitucional de derecho, cit., p. 66-67; Id. Democracia y garantismo. 2. ed. Madrid: Trotta, 2010. p. 29-30).

${ }^{42}$ Elías Díaz, avançando um pouco mais, aponta quatro caracteres gerais do Estado de Direito: a) império da lei sobre os governantes e os cidadãos; b) divisão de poderes entre legislativo, executivo e judiciário; c) fiscalização da Administração; d) proteção dos direitos e liberdades fundamentais. (Estado de derecho y sociedad democrática. In: DE GIORGI, Raffaele (Org.). Il diritto e la differenza. Lecce: Pensa Multimedia, 2002. p. 60).

${ }^{43}$ Trata-se da primeira fase evolutiva do Estado de Direito, orientado contra o Estado absolutista, nas palavras de Gilmar Mendes, "caracterizado, em sua essência, como aquele Estado submetido ao direito, aquele Estado cujo poder e atividade estão regulados e controlados pela lei, entendo-se direito e lei, nesse contexto, como expressão da vontade geral." (Curso de direito constitucional, cit., p. 43). García Pelayo lembra, porém, que o Estado de Direito, ao menos em um primeiro momento, não se identifica com qualquer legalidade, "sino precisamente con una legalidad destinada a garantizar ciertos valores jurídicopolíticos, ciertos derechos imaginados como naturales que garanticen el libre despliegue de la existência burguesa" (Las transformaciones del Estado contemporáneo. Madrid: Alianza Editorial, 2005. p. 53).
} 
No Estado Legal de Direito vigora um direito extremamente codificado, apresentando-se como texto principal o Código Civil - que se coloca como centro do sistema jurídico -, seguido pelo Código Penal. Neste modelo, vigência e validade praticamente se confundem ${ }^{44}$, não havendo qualquer controle jurídico acerca do conteúdo da norma elaborada pelo Legislativo.

Em um segundo momento, após a Segunda Guerra Mundial e também, parcialmente, como consequência desse conflito ${ }^{45}$, inicia-se a formatação de um Estado Constitucional de Direito, no qual a legalidade passa a se subordinar a Constituições rígidas, sendo que, com a instituição do sistema de controle judicial de constitucionalidade, por meio do qual as leis se submetem a um controle de vigência (formal) e de validade (material), chega-se ao modelo de Estado Constitucional de Direito atual, presente, sobretudo, nas Constituições nascidas após o conflito ${ }^{46}$.

Neste modelo, portanto, desenha-se uma complexa estrutura normativa na qual a validade das normas reside na sua correspondência não somente formal como também material com normas de categoria superior, que não só regulam as formas senão que estabelecem também limitações de conteúdo ao exercício do poder normativo, em uma clara dissociação entre vigência e validade ${ }^{47}$.

\footnotetext{
44، La vigencia tine relación com la produccion formal de la norma, esto es, que haya sido elaborada por una autoridade competente y de acuerdo con el procedimento también estabelecido por uma norma; la validez tiene relación con el contenido de la norma. La vigência se verifica al responder las perguntas quién y como; la validez, al responder qué." (ÁVILA SANTAMARÍA, Ramiro. op. cit., p. 782).

${ }^{45}$ Luigi Ferrajoli lembra que "en el clima cutural e político que acompañó el nascimento del constitucionalismo actual (...) se toma consciência de que el consenso de las masas en el que se hábian fundado también las dictaduras fascistas no basta para garantizar la calidad de um sistema político. Y se vuelve, por tanto, a descobrir el significado y el valor de la constituición como limite y vínculo de cualquer poder, incluso mayoritario (FERRAJOLI, Luigi. Sobre el papel cívico y político de la ciencia penal en el Estado constitucional de derecho, cit., p. 66-67).

${ }^{46}$ FELDENS, Luciano. A Constituição penal: a dupla face da proporcionalidade no controle de normas penais, cit., p. 28-38. Neste ponto, vale transcrever as lições de Francesco Palazzo: "Del 'Estado de derecho al 'Estado constitucional de derecho': ésta es la tendencia de las transformaciones verificadas durante este siglo en la historia constitucional de los principales Estados europeos e extraeuropeos. Si el carácter fundamental próprio del Estado es someter también al poder público en su diversas formas de manifestación al vinculo de la regula iuris predeterminada tal y como lo están todos los otros sujetos del ordenamiento, la idea del Estado constitucional de derecho expressa actualmente algo más.De uma garantia, fundamental peró aún 'formal', como es la que ofrece el Estado de Derecho, se llega en las modernas constituiciones de origen liberal-democrático a uma garantia de tipo 'material' o 'de contenido' "(Estado constitucional de derecho y derecho penal, cit., p. 49).

${ }^{47}$ FERRAJOLI, Luigi. Direito e razão: teoria do garantismo penal, cit., p. 325-338. Id. Pasado y futuro del Estado de derecho, cit., p. 18. FELDENS, Luciano. A Constituição penal: a dupla face da proporcionalidade no controle de normas penais, cit., p. 33-34.
} 
No Estado Constitucional de Direito, as Constituições incorporam uma seleção de valores fundamentais - normatizados sobretudo por meio de princípios - que se impõem ao legislador e ao poder público em geral como critérios materiais de legitimidade ${ }^{48}$.

Assim, enquanto o Estado Legal de Direito identifica o Direito com a lei ou com as normas ditadas em função de uma lei, o Estado Constitucional de Direito eleva a Constituição desde o plano programático ao mundo das normas jurídicas vinculatórias e, por conseguinte, não somente acolhe o princípio da legalidade como o complementa com o princípio da supremacia da Constituição sobre a lei e, portanto, sobre todo o ordenamento jurídico $^{49}$. O juiz, no modelo de Estado Constitucional, deixa de ser a "boca da lei", apenas se obrigando à aplicação da lei válida, e ela o será quando se encontrar em situação de conformação formal e material à Constituição ${ }^{50}$. Essa sujeição à Constituição acaba por impor ao juiz o papel essencial de crítico das leis inválidas, através da declaração de sua inconstitucionalidade ou por meio de sua intepretação de acordo com o texto constitucional ${ }^{51}$.

Nesse cenário, como decorrência da evolução do modelo de Estado, é exatamente nesse momento do $2^{\circ}$ pós-guerra que começa a se desenvolver na Europa uma nova forma de encarar a Constituição, um novo modelo de constitucionalismo, que vem sendo chamado - talvez provisoriamente - de neoconstitucionalismo ${ }^{52}$, colocando-se como uma nova proposta para a compreensão e implementação do texto constitucional.

\footnotetext{
${ }^{48}$ PALAZZO, Francesco. Estado constitucional de derecho y derecho penal, cit., p. 49. Ferrajoli chega a definir tal modelo como "sistema de limites e de vínculos impostos para a garantia dos direitos fundamentais de todos" $(\mathrm{O}$ Estado constitucional de direito hoje: o modelo e a sua discrepância com a realidade, cit., p. 40).

${ }^{49}$ GARCÍA-PELAYO, Manuel. Estado legal e Estado constitucional de derecho, cit., p. 40-41.

${ }^{50}$ FELDENS, Luciano. A Constituição penal: a dupla face da proporcionalidade no controle de normas penais, cit., p. 37. FERRAJOLI, Luigi. Sobre el papel cívico y político de la ciencia penal en el Estado constitucional de derecho, cit., p. 69.

${ }^{51}$ FERRAJOLI, Luigi. Democracia y garantismo, cit., p. 31.

${ }^{52}$ Costuma-se apontar como fundamental sobre o assunto a obra coordenada por Miguel Carbonell (Neoconstitucionalismo(s). 4. ed. Madrid: Trotta, 2009). No Brasil, mostra-se crescente o número de importantes estudos acerca do tema: BARROSO, Luís Roberto. Neoconstitucionalismo e constitucionalização do direito: o triunfo tardio do direito constitucional no Brasil. Revista da Emerj, Rio de Janeiro, v. 9, n. 33, 2006; SARMENTO, Daniel. O neoconstitucionalismo no Brasil: riscos e possibilidades. In: LEITE, George Salomão; SARLET, Ingo Wolfgang (Orgs.). Direitos fundamentais $e$ Estado constitucional. São Paulo: Ed. Revista dos Tribunais; Coimbra: Coimbra Ed., 2009. p. 9-49. BARCELLOS, Ana Paula de. Neoconstitucionalismo, direitos fundamentais e controle das políticas públicas. In: SARMENTO, Daniel; GALDINO, Flávio (Orgs.). Direitos fundamentais. Rio de Janeiro: Renovar, 2006. MOREIRA, Eduardo Ribeiro. Neoconstitucionalismo: a invasão da Constituição. São Paulo: Método, 2008. Para uma visão crítica, cf. ÁVILA, Humberto. Neoconstitucionalismo: entre a "Ciência do Direito" e o "Direito da Ciência". Revista Brasileira de Direito Público, Belo Horizonte, ano 6, v. 23, p. 9, 2008. No âmbito do STF, a expressão "Neoconstitucionalismo" é adotada, p. ex, pelo Ministro Celso de Mello, destacando a "força normativa dos princípios constitucionais" e o "fortalecimento da jurisdição constitucional”. Cf. p. ex, STF - RE 477.554 AgR /MG. j.16/08/2011.
} 
No Brasil, as transformações do constitucionalismo são protagonizadas pela Constituição de 1988 e impulsionadas pela evolução da doutrina constitucional, principalmente nas últimas duas décadas ${ }^{53}$.

A Constituição finalmente deixa de ser uma fantasia, uma carta meramente programática, um corpo frio e distante da realidade, para adquirir força normativa ${ }^{54}$, com aplicabilidade direta e imediata ${ }^{55}$.

Observa-se o fenômeno conhecido como constitucionalização do Direito, segundo o qual todos os ramos jurídicos passam a ser obrigatoriamente lidos, (re)construídos e interpretados a partir da Constituição, a qual assume a posição de centro do sistema ${ }^{56}$. A Constituição funciona, assim, não apenas como parâmetro de validade para a ordem infraconstitucional, mas também como vetor de interpretação de todas as normas do sistema $^{57}$. Para garantir a sua efetividade, e, sobretudo, o respeito aos direitos

\footnotetext{
${ }^{53}$ Nesse sentido, BARROSO, Luís Roberto. A Constituição Brasileira de 1988: uma introdução, cit., p. 35 e seg. Humberto Ávila ressalta que o que "se convencionou chamar de 'neoconstitucionalismo' foi um dos fenômenos mais visíveis da teorização e aplicação do Direito Constitucional nos últimos 20 anos no Brasil", ressalvando que "não há apenas um conceito de 'neoconstitucionalismo", pois "a diversidade de autores, concepções, elementos e perspectiva é tanta, que torna inviável esboçar uma teoria única de 'neoconstitucionalismo'." (Neoconstitucionalismo: entre a "Ciência do Direito" e o "Direito da Ciência", cit., p. 9). Daniel Sarmento informa que a emergência de um novo paradigma, que tem sido designado neoconstitucionalismo, envolve tanto a teoria jurídica quanto a prática dos tribunais, destacando que, embora "não exista um único neoconstitucionalismo", as diversas visões sobre o fenômeno guardam entre si "denominadores comuns relevantes", "diversos pontos de
} convergência". (O neoconstitucionalismo no Brasil: riscos e possibilidades, cit., p. 9-49).

${ }^{54}$ Costuma-se apontar como fundamental sobre o tema o pequeno texto de Konrad Hesse. (A força normativa da Constituição. Porto Alegre: Safe, 1991).

${ }^{55}$ BARROSO, Luís Roberto. A Constituição Brasileira de 1988: uma introdução, cit., v. 1, p. 9-41. O autor descreve com precisão o novo cenário: "No Brasil, a partir de 1988 e, especialmente nos últimos anos, a Constituição passou a desfrutar, além da supremacia formal que sempre teve, também de uma supremacia material, axiológica, potencializada pela abertura do sistema jurídico e pela normatividade dos princípios. (...) A constitucionalização identifica um efeito expansivo das normas constitucionais que se irradiam por todo o sistema jurídico. Os valores, os fins públicos e os comportamentos contemplados nos princípios e regras da Lei Maior passam a condicionar a validade e o sentido de todas as normas do direito infraconstitucional. À luz de tais premissas, toda intepretação jurídica é também uma interpretação constitucional. Qualquer operação de realização do Direito envolve a aplicação direta ou indireta da Constituição. Direta, quando uma pretensão se fundar em uma norma constitucional; e indireta quando se fundar em uma norma infraconstitucional, por duas razões: a) antes de aplicar a norma, o interprete deverá verificar se ela é compatível com a Constituição, porque, se não for, não poderá fazer incidi-la; e b) ao aplicar a norma, deverá orientar seu sentido e alcance à realização dos fins constitucionais.". García-Pelayo, no mesmo sentido, afirma que "todo deriva de la Constitucíon y todo ha de legitimarse por su conconcordancia directa o indirecta con la Constituicíón" (Estado legal e Estado constitucional de derecho, cit., p. 41).

${ }^{56}$ Muitos autores trabalham este fenômeno no contexto de uma verdadeira mudança de paradigma jurídico, representado pela superação do positivismo e pelo nascimento do pós-positivismo. Cf., p. ex., comparativamente: AGUILÓ REGLA, Josep. Del "império de la ley" al "estado constitucional": dos paradigmas en pocas palabras. In: MOREIRA, Eduardo Ribeiro; PUGLIESI, Márcio (Coords.). 20 anos da Constituição brasileira. São Paulo: Saraiva, 2009. p. 97-109. Apontando o pós-positivismo como marco filosófico do neoconstitucionalismo, cf. BARROSO, Luís Roberto. Neoconstitucionalismo e constitucionalização do direito: o triunfo tardio do direito constitucional no Brasil, cit., p. 57.

${ }^{57}$ BARROSO, Luís Roberto. Neoconstitucionalismo e constitucionalização do direito: o triunfo tardio do direito constitucional no Brasil, cit. 
fundamentais nela insculpidos, são fortalecidos e diversificados os mecanismos de controle de constitucionalidade.

Princípios e regras constitucionais são, dessa forma, reconhecidos como normas que se irradiam por todo o ordenamento jurídico, independentemente da atuação do legislador $^{58}$. A evolução do constitucionalismo impacta todos os ramos do Direito, contribuindo para o desenvolvimento de idéias de um Direito Civil constitucional ${ }^{59}$, de um Direito Administrativo constitucional $^{60}$, de um Direito Processual Penal constitucional $^{61}$, de um Direito Penal constitucional etc.

Como visto, o legislador ordinário deixa de gozar de uma liberdade quase absoluta e passa a vincular-se, formal e materialmente, ao texto constitucional. Mas não somente a atuação do legislador passa a ser, efetivamente, limitada pela Constituição. As normas constitucionais não permitem opções livres a todos os órgãos e agentes concretizadores da Constituição ${ }^{62}$, atingindo os poderes Judiciário, Legislativo e Executivo ${ }^{63}$ e também a relação entre particulares ${ }^{64}$, sendo possível referir-se a uma verdadeira "invasão da Constituição"65.

\footnotetext{
${ }^{58}$ No que tange aos direitos fundamentais, a Constituição é expressa em ordenar a aplicação de suas normas sem qualquer mediação $\left(\operatorname{art.5}, \S 1^{\circ}\right)$.

${ }^{59}$ Cf., p. ex.: TEPEDINO, Gustavo. Temas de direito civil. Rio de Janeiro: Renovar, 2004; TEPEDINO, Gustavo (Coord.). Problemas de direito civil-constitucional. Rio de Janeiro: Renovar, 2000; MORAES, Maria Celina Bodin de. A caminho de um direito civil constitucional. Revista de Direito Civil Imobiliário, Agrário e Empresarial, São Paulo, n. 65, p. 21-32, 2003. MARTINS-COSTA, Judith (Org.). A reconstrução do direito privado: reflexos dos princípios, diretrizes e direitos fundamentais constitucionais no direito privado. São Paulo: Ed. Revista dos Tribunais, 2002.

${ }^{60}$ Cf, p. ex, BAPTISTA, Patrícia. Transformações do direito administrativo. Rio de Janeiro: Renovar, 2003.

${ }^{61}$ Cf., p. ex., LOPES JUNIOR, Aury. Direito processual penal e sua conformidade constitucional. 7. ed. Rio de Janeiro: Lumen Juris, 2011. v. 1 e 2.

${ }^{62}$ CANOTILHO, J. J Gomes. op. cit., p. 1183.

63،"Por 'constitucionalización del ordenamento jurídico' propongo entender un proceso de transformacíon de um ordenamento al término del cual el ordenamiento en cuestíon resulta totalmente 'impregnado' por las normas constitucionales. Un ordenamiento juridico constitucionalizado se caracteriza por una Constitución extremamente invasora, entrometida (pervasiva, invadente), capaz de condicionar tanto la legislacíon como la jurisprudenca y el estilo doctrinal, la accíon de los actores políticos, así como las relaciones sociales." (GUASTINI, Riccardo. La "Constitucionalizacíon" del Ordenamiento Jurídico: el Caso Italiano. In: CARBONELL, Miguel (Org.). Neoconstitucionalismo(s). 4. ed. Madrid: Trotta, 2009. p. 49) Defendendo a atuação das normas constitucionais inclusive na definição das políticas públicas em geral, cf. BARCELLOS, Ana Paula de. op. cit.

${ }^{64}$ Fala-se, hoje, em "eficácia horizontal dos direitos fundamentais". Cf. SARMENTO, Daniel. Direitos fundamentais e relações privadas. 2. ed. Rio de Janeiro: Lumen Juris, 2006; SILVA, Virgílio Afonso da. A constitucionalização do direito: os direitos fundamentais nas relações entre particulares. São Paulo: Malheiros Ed., 2005. Cf., ainda, STF - RE 201819 / RJ. Rel.Min.Ellen Gracie. j.11/10.2005.

${ }^{65}$ MOREIRA, Eduardo Ribeiro. op. cit.
} 
Verifica-se, ao menos nesse cenário de transição, o fortalecimento do Poder Judiciário $^{66}$ - com destaque para os tribunais constitucionais - que passa a atuar não somente como fiscal da legalidade e da observância das formas, mas, cada vez mais, também como garante do conteúdo material das normas constitucionais ${ }^{67}$.

Com efeito, desenvolvem-se, no âmbito do Judiciário, mecanismos de realização concreta dessa supremacia formal e material da Constituição que incluem ${ }^{68}$ : a) o reconhecimento da não recepção (ou da revogação) de normas infraconstitucionais anteriores à Constituição, quando com ela incompatíveis; b) a declaração de inconstitucionalidade de normas infraconstitucionais, quando com ela incompatíveis; c) a declaração de inconstitucionalidade por omissão, com a conseqüente convocação à atuação do legislador; d) a interpretação conforme a Constituição ${ }^{69}$, técnica que consiste em afastar, dentre as várias interpretações possíveis ou dentre as diversas normas passíveis de serem extraídas de determinado dispositivo, aquelas que sejam incompatíveis como as normas constitucionais.

Pode-se dizer, portanto, que o Estado Constitucional de Direito, impulsionado pela evolução do constitucionalismo, está, de fato, conduzindo a Constituição ao centro dos debates, de uma forma jamais vista. Fala-se, até mesmo, no nascimento de um "sentimento constitucional" 70 no Brasil, fomentado pela criação da TV Justiça e pela inclusão crescente de temas jurídicos, do Poder Judiciário, notadamente do Supremo Tribunal Federal, na pauta dos principais órgãos de imprensa. A palavra "Constituição",

\footnotetext{
${ }^{66}$ BARROSO, Luís Roberto. Neoconstitucionalismo e constitucionalização do direito: o triunfo tardio do direito constitucional no Brasil, cit.

${ }^{67}$ Pode-se dizer que, de um modo geral, os tribunais brasileiros vêm, paulatinamente, não sem resistência, assimilando o atual modelo de Estado e assumindo esta função. Cf, p. ex, entre muitos: STF (ADPF n 187. Rel.Min.Celso de Mello. j.15/06/2001, HC nº 82.959/SP, rel. min. Marco Aurélio. J.23/02/2006); STJ (HC 197.601-RJ, Rel. Min. Maria Thereza de Assis Moura, julgado em 28/6/2011). Para uma análise da situação na Alemanha, cf. ALEXY, Robert. Los derechos fundamentales en el Estado Constitucional Democrático. In: CARBONELL, Miguel (Org.). Neoconstitucionalismo(s). 4. ed. Madrid: Trotta, 2009. p. 31-47. Na Itália, cf. GUASTINI, Riccardo. op. cit., p. 49-73.

${ }^{68}$ BARROSO, Luís Roberto. Neoconstitucionalismo e constitucionalização do direito: o triunfo tardio do direito constitucional no Brasil, cit., p. 57.

${ }^{69}$ BONAVIDES, Paulo. Curso de direito constitucional. 12. ed. São Paulo: Malheiros Ed., 2002. p. 473-480. BARROSO, Luís Roberto. Interpretação e aplicação da Constituição: fundamentos de uma dogmática constitucional transformadora, cit., p. 193-201 e p. 373. Técnica já muito utilizada no âmbito do Supremo Tribunal Federal. Como exemplo, tem-se a ADPF n 187, já citada, sobre a chama "marcha da maconha", julgada procedente "de forma a excluir qualquer exegese que possa ensejar a criminalização da defesa da legalização das drogas, ou de qualquer substância entorpecente específica, inclusive através de manifestações e eventos públicos." (STF. Rel. Min. Celso de Mello. j.15/06/2001).

${ }^{70}$ BARROSO, Luís Roberto. A Constituição Brasileira de 1988: uma introdução, cit., p. 342.
} 
antes restrita a (poucos) juristas e cientistas políticos, parece, de fato, pouco a pouco, estar se incorporando ao vocabulário e à vida cotidiana das pessoas.

O mais importante, porém, no âmbito do presente trabalho, é compreender o atual modelo de Estado como normativo-juridicamente vinculado aos valores e finalidades expressos nas normas constitucionais, característica essencial de um verdadeiro Estado Constitucional de Direito.

\subsection{Estado Democrático de Direito}

Tendo já bem clara a evolução da estrutura normativa do Estado, chegando-se ao modelo de Estado Constitucional, passa-se, agora, a analisar a evolução do próprio conteúdo do Estado, ou seja, dos fins, valores, objetivos, tarefas, direitos reconhecidos, além da forma de exercício de poder, chegando-se, então, ao modelo de Estado Democrático de Direito, expressamente adotado pela atual Constituição brasileira, logo em seu art. $1^{\text {o71 }}$.

Tomando-se como pressuposto e ponto de partida a submissão do Estado e de todos os cidadãos a normas jurídicas pré-definidas - Estado de Direito --, parte-se, neste momento, para o estudo do conteúdo geral dessas normas, as quais têm o condão de desenhar a relação entre Estado-indivíduo e, também, entre indivíduo-indivíduo.

Por certo, vale lembrar, antes de tudo, que a formatação de cada modelo vinculase, necessariamente, ao contexto econômico, político, científico e cultural de cada momento histórico, sendo imperioso considerar que a evolução dos modelos não se desenvolve de maneira absolutamente linear e simplificada, como comumente ocorre no percurso das instituições e do Estado $^{72}$.

Dito isso, vale dizer que, em um cenário de superação de formas autoritárias de Estado e de ascensão política de uma burguesia economicamente dominante, emerge, inicialmente, um modelo de Estado extremamente preocupado com as liberdades individuais, com a imposição de largos limites à influência estatal sobre a sociedade, nos

\footnotetext{
71، Art. $1^{\circ}$ - A República Federativa do Brasil, formada pela união indissolúvel dos Estados e Municípios e do Distrito Federal, constitui-se em Estado Democrático de Direito e tem como fundamentos: (...).” (grifos nossos).

${ }^{72}$ Elías Díaz lembra que o processo histórico ocorre "conflictivamente”, "non si recaídas, retrocesos, distorsiones y más o menos árduas evoluciones” (Estado de derecho y sociedad democrática, cit., p. 63).
} 
seus mais variados aspectos, destacando-se a proteção da autonomia individual, da propriedade privada e do livre mercado.

Trata-se de um modelo denominado de Estado Liberal de Direito - ancorado nos ideais iluministas e deflagrado principalmente pelo processo revolucionário francês, descrito na Declaração de Direitos do Homem e do Cidadão de $1789^{73}$ - no qual predomina a imposição de obrigações negativas ao Estado, concretizadas em deveres de não intervenção, de não ingerência. O Estado se coloca, assim, essencialmente, como garantidor de liberdades, respeitando-se a autonomia de cada cidadão, sendo esta a sua principal tarefa legítima.

Coloca-se entre os principais objetivos do Estado Liberal, portanto, a garantia dos direitos fundamentais do indivíduo, tais como o direito às liberdades de locomoção, de manifestação de ideias e pensamentos, liberdade religiosa, entre outras ${ }^{74}$. No plano político, surgem os primeiros elementos politico-democráticos, a exemplo da noção de soberania popular e do entendimento da Lei como expressão da vontade geral, sendo que aquela deve ser a mesma para todos.

O modelo de Estado Liberal foi predominante durante todo o século XIX e início do século XX, até que o acontecimento da Primeira Guerra Mundial acabou por expor suas deficiências, trazendo à tona uma série de críticas. ${ }^{75}$ Percebeu-se, sobretudo, que tal modelo havia conduzido a uma concentração de riquezas extraordinária, e, associado ao sistema capitalista de produção desencadeado pela Revolução Industrial, proporcionou um cenário de domínio e exploração da mão de obra pela classe economicamente dominante, detentora dos meios de produção e, também, do poder político. No âmbito internacional, a exploração se dava em detrimento das nações

\footnotetext{
${ }^{73}$ Costuma-se a apontar como alguns dos principais teóricos do Estado Liberal os britânicos John Locke e Adam Smith. Cf., p. ex., fazendo referência às anteriores Declarações de Direitos de 1689 na Inglaterra e à Declaração Norte-Americana de 1776, DÍAZ, Eliás. op. cit., p. 58-59.

${ }^{74}$ Elías Díaz aponta como principais características do Estado Liberal a declaração e proteção jurídica das liberdades e direitos fundamentais, civis e políticos, a sacralização da propriedade privada individual e uma sociedade individualista. (Id. Ibid., p. 64-65). Ana Elisa Liberatore Bechara, por sua vez, lembra que, seguindo a elaboração iluminista, "o modelo liberal sustenta-se a partir de uma filosofia individualista que coloca o cidadão - racional, autônomo, responsável e livre - no centro da sociedade, reconhecendo e garantindo seus direitos fundamentais, tais como a vida, a integridade física, a liberdade de expressão e a propriedade privada, tipicamente identificados com a burguesia, no âmbito de uma concepção negativa de liberdade." (Da teoria do bem jurídico como critério de legitimidade do direito penal, cit., p. 29).

${ }^{75}$ Para uma visão crítica do Estado Liberal, cf. BONAVIDES, Paulo. Do Estado liberal ao Estado social. 10. ed. São Paulo: Malheiros Ed., 2011. Manuel Garcia-Pelayo aponta com uma de suas principais críticas ao modelo Liberal a existência de uma verdadeira oposição entre Estado e sociedade, o que acarretava uma inibição do Estado frente aos problemas econômicos e sociais. (Las transformaciones del Estado contemporáneo, cit., p. 21-22).
} 
mais pobres, no contexto de um neocolonialismo, sendo a disputa por mercados a razão principal da eclosão do conflito mundial.

Verificou-se, ainda, que os direitos insculpidos ou inspirados na Declaração de Direitos do Homem e do Cidadão não assumiram a universalidade aclamada, restando submetidos a interesses circunstanciais da burguesia dominante, em um ambiente social e político marcado por sinais de uma igualdade e uma democracia apenas formais. Apenas como ilustração, vale lembrar que o Estado Liberal conviveu bastante tempo com a escravidão, hipocritamente.

Em um segundo momento, portanto, como forma de superação das deficiências do modelo Liberal - porém, sem negar seus valores essenciais -, constrói-se um novo modelo, consagrador de um Estado extremamente interventor, sobretudo no campo social e econômico. Trata-se do modelo de Estado Social de Direito, no qual são impostos ao Estado verdadeiros deveres de atuação, consistentes em obrigações positivas e não mais meramente negativas ${ }^{76}$. Parte-se da experiência de que a sociedade deixada total ou parcialmente a seus mecanismos de autorregulação conduz à pura irracionalidade e, que somente a ação do Estado - por meio do desenvolvimento de técnicas administrativas, econômicas, de programação de decisões, etc - pode neutralizar os efeitos disfuncionais de um desenvolvimento econômico e social não controlado ${ }^{77}$. Busca-se, assim, ao invés de proteger a sociedade do Estado, proteger a sociedade por meio da ação do Estado $^{78}$.

O Estado é, então, chamado a atuar para conferir materialidade aos direitos apenas formalmente conquistados, com forte intervenção na área econômica com vistas a diminuir a desigualdade social, visando a realização dos objetivos de justiça social, em superação aos excessos do individualismo liberal. Além disso, inaugura-se uma nova categoria de direitos, a exemplo do direito ao trabalho, à educação e à saúde, os quais materializam exigências do bem-estar geral (Welfare State). Verifica-se, nesse sentido, um aprofundamento dos elementos democráticos, com a implantação de políticas de bemestar e adoção do sufrágio universal ${ }^{79}$.

\footnotetext{
${ }^{76}$ Luigi Ferrajoli fala em garantias liberais negativas e garantias sociais positivas (Direito e razão: teoria do garantismo penal, cit., p. 793-795). Cf., no mesmo sentido, GARCÍA-PELAYO, Manuel. Las transformaciones del Estado contemporáneo, cit., p. 51-56.

${ }^{77}$ GARCÍA-PELAYO, Manuel. Las transformaciones del Estado contemporáneo, cit., p. 22-23.

${ }^{78}$ Id. Ibid., p. 27.

${ }^{79}$ DÍAZ, Eliás. op. cit., p. 65.
} 
O modelo de Estado Social, embora tenha trazido inegáveis conquistas, também foi alvo de duras críticas, tendo sido apontado como responsável por proporcionar uma nova concentração de poder nas mãos do Estado, sendo este muitas vezes comandado segundo interesses escusos ${ }^{80}$, gerando, no grau máximo, distorções como o nazismo e o fascismo, as quais culminaram na $2^{\mathrm{a}}$ Guerra Mundial. Foi, ainda, criticado por não ter alcançado o objetivo de promover a tão aclamada justiça social ${ }^{81}$.

Não bastasse, o Estado social foi taxado de excessivamente burocrático e paternalista, sobretudo ao atribuir aos governados a condição de clientes, ávidos por uma prestação estatal, e não de cidadãos inseridos em um cenário democrático e participativo.

Assim, após a Segunda Guerra Mundial, e, logicamente, também como consequência deste conflito, a partir da segunda metade do século $\mathrm{XX}^{82}$, inicia-se o desenvolvimento de um modelo de Estado Democrático de Direito, o qual, além de constituir uma espécie de síntese dos modelos anteriores ${ }^{83}$, agrega novas finalidades e valores fundamentais ao Estado, aspirante a uma democracia de cunho material ${ }^{84}$. Na realidade, o vocábulo "democrático" irradia valores da democracia sobre todos os elementos constitutivos do Estado e, assim, sobre toda a ordem jurídica ${ }^{85}$.

\footnotetext{
${ }^{80}$ Como bem ressaltado por José Afonso da Silva, o Estado Social nem sempre apresentou "conteúdo democrático". (Curso de direito constitucional positivo, cit., p. 112).

${ }^{81}$ “La tendência intervencionista del Estado social condujo en algunos países a sistemas políticos totalitários, lo que culminó en el período que medió entre las dos guerras mundiales. La experiência de los horrores que ello trajo consigo, primeiro en la paz y logo con la guerra, hizo evidente la necessidad de un Estado que, sin abandonar su deveres con la sociedad, es decir, sin dejar de ser social, reforzase sus limites jurídicos em um sentido democrático." (MIR PUIG, Santiago. Derecho penal: parte general. 9. ed. Madrid: Reppertor, 2012. p. 94).

${ }^{82}$ De modo simplificado, pode-se apontar como marco inicial deste modelo os documentos nascidos após a derrota do nazismo e do fascismo, no âmbito da $2^{\text {a }}$ Guerra Mundial: Declaração Universal dos Direitos Humanos (1948), e as Constituições da Itália (1948) e da Alemanha (1949). Em um segundo momento: Constituições de Portugal (1976) e da Espanha (1978).

${ }^{83}$ Também nesse sentido, entendendo o Estado Democrático de Direito como síntese e não como oposição aos modelos anteriores: MENDES, Gilmar Ferreira et al. op. cit., 2008, p. 149; BECHARA, Ana Elisa Liberatore Silva. op. cit., p. 28). Cf., também, ressaltando uma concepção sintética, embora valendo-se da expressão "Estado Social y Democrático de Derecho", MIR PUIG, Santiago. La nueva constitución española y el derecho penal: fundamento constitucional de la pena y teoría del delito, cit., p. 525-560. Em sentido semelhante, Miguel Reale Júnior chega a definir o Estado Democrático de Direito como "um momento de acúmulo de conquistas de valores políticos e sociais incrustados em nossa consciência". E completa: "A Constituição em um Estado Democrático de Direito se, de um lado, consagra direitos fundamentais e estabelece limites ao poder político, instituindo princípios básicos de proteção do indivíduo frente ao Estado, por outro, fixa diretrizes, com a finalidade de promover valores e ações de cunho social" (Instituições de direito penal, cit., p. 24 e 26).

${ }^{84}$ Luigi Ferrajoli aponta para uma democracia substancial, na qual, além de se determinar quem decide e como se decide, deve-se discutir o que é lícito decidir e o que não é lícito decidir. (Direito e razão: teoria do garantismo penal, cit., p. 797-799; Id. Democracia y garantismo, p. 30-32).

${ }^{85}$ SILVA, José Afonso da. op. cit., p. 119 , 123 e seg.
} 
No Estado Democrático, busca-se a superação das deficiências dos modelos Liberal e Social, garantindo-se a liberdade humana por excelência e apresentando-se instrumentos efetivos de controle do poder e de materialização de direitos, não somente dos direitos civis e políticos, mas também e sobretudo dos direitos econômicos, sociais e culturais $^{86}$. Abandona-se a ideia de um intervencionismo quantitativo e parte-se para um modelo de Estado de intervenção muito mais qualitativa e seletiva ${ }^{87}$.

O Estado Democrático coloca-se, fundamentalmente, como Estado pluralista, tolerante, laico, multicultural, garantidor das liberdades e das diferenças de todo tipo, baseado na dignidade humana e no livre desenvolvimento da personalidade ${ }^{88}$, extremamente aberto à participação política popular ${ }^{89}$, e também voltado para novas questões de destaque, como o meio ambiente. ${ }^{90}$

Neste modelo, verifica-se uma densificação dos direitos fundamentais ${ }^{91}$, os quais, expressos principalmente por meio de princípios, assumem uma posição central em todo

\footnotetext{
${ }^{86}$ MENDES, Gilmar Ferreira et al. op. cit., 2008, p. 149.

${ }^{87}$ DÍAZ, Eliás. op. cit., p. 69-70. Apoiando-se nas lições deste autor, pode-se afirmar, ainda, que, no Estado Democrático de Direito, a sociedade é marcada por uma "libre autoexigencia personal para uma ética del trabajo, del esfuerzo, del mérito, la capacidade, la intervencíon participativa y solidaria", em detrimento de uma "ética de la irresponsabilidade individual esperandolo del Papa-Estado", típica do Estado Social, e de "la exclusiva práctica de la individualista competividad", presente no Estado Liberal.

${ }^{88}$ Também destacando a relação do Estado Democrático de Direito com uma concepção plural de sociedade e com a promoção de valores como a dignidade, a liberdade e o livre desenvolvimento da personalidade de forma material, cf. PRADO, Luis Regis. Bem jurídico-penal e Constituição, cit., p. 68-69. De forma semelhante, BECHARA, Ana Elisa Liberatore Silva. op. cit., p. 33 e seg.

${ }^{89}$ Em sentido semelhante, José Afonso da Silva afirma que: "a democracia que o Estado Democrático de Direito realiza há de ser um processo de convivência social numa sociedade livre, justa e solidária (art. $3^{\circ}$, I), em que o poder emana do povo, e deve ser exercido em proveito do povo, diretamente ou por representantes eleitos (at. $1^{\circ}$, parágrafo único); participativa, porque envolve a participação crescente do povo no processo decisório e na formação dos atos de governo; pluralista, porque respeita a pluralidade de ideias, culturas, etnias e pressupõe assim o diálogo entre opiniões e pensamentos divergentes e a possibilidade de convivência de formas de organização e interesses diferentes da sociedade; há de ser um processo de liberação da pessoa humana das formas de opressão que não depende apenas do reconhecimento formal de certos direitos individuais, políticos e sociais, mas especialmente da vigência de condições econômicas suscetíveis de favorecer o seu pleno exercício." (Curso de direito constitucional positivo, cit., p. 119-120).

${ }^{90}$ Sobre essas novas questões, vale transcrever passagem de Elías Díaz: “Asumiendo, claro está, los derechos civiles y políticos (incorporados en el Estado liberal), así como los derechos socioeconómicos y culturales (objetivo prevalente, junto a aquellos, del Estado social) ahora son novos derechos - terceira genecíon - los que reclaman de un modo u de outro su presencia: derechos de las minorias étnicas, los derivados de las diferencias sexuales, linguísticas, de la marginacíon por diferentes causas, derechos de los inmigrantes, ancianos, niños, mujeres, derechos em relacíon com el médio ambiente, las generaciones futuras, la paz, el desarrollo económico de los pueblos, la demografia, las manipulaciones genéticas, las nuevos tecnologías, etc. en todo menos que arbitraria, cerrada y exhaustiva." (Estado de derecho y sociedad democrática, cit., p. 72).

${ }^{91}$ MENDES, Gilmar Ferreira et al. op. cit., 2008, p. 44.
} 
o sistema jurídico. A existência de conflitos entre direitos fundamentais, aliás, afigura-se como essência do próprio sistema ${ }^{92}$, decorrência do próprio pluralismo democrático.

Fundamental destacar que, neste modelo de Estado, os direitos fundamentais devem ser assegurados ainda que contra as expectativas e pretensões da maioria ou, até mesmo, da unanimidade dos membros da sociedade, o que acaba por revelar um verdadeiro caráter contramajoritário dos direitos fundamentais ${ }^{93}$. O Estado Democrático de Direito é - em essência - o locus da contestação, da controvérsia, da tolerância com as ações, pensamentos e com os demais tipos de manifestação dos grupos minoritários e de cada pessoa individualmente considerada Nesse modelo, abre-se o espaço para o livre jogo das alternativas, possibilitando que qualquer concepção, ideia ou tendência minoritária se torne majoritária algum dia. Por essa razão, são estabelecidos limites a todo e qualquer poder, inclusive ao da maioria ${ }^{94}$.

O Estado Democrático de Direito tem como objetivo, também, superar o hermetismo dos modelos anteriores, declarando-se um modelo aberto, em permanente discussão e construção, fundado em valores adotados explícita ou implicitamente pelo texto constitucional, ou originários da ordem internacional.

Importante salientar, ainda, que existe, por evidência, uma relação íntima entre a concepção democrática do Estado de Direito e o modelo de Estado Constitucional, descrito no item anterior. Nessa linha, pode-se dizer que é o próprio Estado Constitucional que permite a realização e o aperfeiçoamento do Estado Democrático, ao estabelecer limites ao poder da maioria e, ao mesmo tempo, ao garantir que as proibições e obrigações expressas no texto constitucional sejam elevadas à condição de direito de todos. Além disso, no modelo de Estado Constitucional, como visto, as normas constitucionais acabam por influenciar também as relações políticas e sociais, impactando

\footnotetext{
${ }^{92}$ FERRAJOLI, Luigi. Sobre el papel cívico y político de la ciencia penal en el Estado constitucional de derecho, cit., p. 70.

${ }^{93}$ No Brasil, o Supremo Tribunal Federal vem, cada vez com mais intensidade, afirmando o caráter contramajoritário dos direitos fundamentais. Como exemplo, tem-se o RE 477.554 AgR/MG (Rel.Min.Celso de Mello.j.16/08/2011), que reconheceu a união homoafetiva como entidade familiar, destacando princípios fundamentais do Estado Democrático de Direito, tais como o da dignidade da pessoa humana, da liberdade, da autodeterminação, da igualdade, da intimidade e do pluralismo.

${ }^{94}$ Cf. FERRAJOLI, Luigi. Direito e razão: teoria do garantismo penal, cit., p. 793. e Id. Democracia y garantismo, cit., p. 25-41.
} 
os debates e as relações também nos poderes Executivo e Legislativo, proporcionando a implementação e a irradiação dos valores do Estado Democrático de Direito ${ }^{95}$.

Este é, pois, o modelo de Estado Democrático de Direito vigente atualmente no Brasil e em grande parte dos países do ocidente, com raízes fortemente liberais e defensor de uma intervenção estatal qualitativa no campo social, econômico, ambiental etc., apresentando como maior objetivo a irradiação dos valores democráticos e tendo como principais bandeiras a garantia dos direitos fundamentais a todos e a tolerância perante todo e qualquer tipo de diferença.

Diante de todo o até aqui estudado, parece evidente que toda essa evolução normativa e de conteúdo - do modelo de Estado impacta diretamente o Direito Penal - setor no qual se dá a relação mais sensível entre Estado e indivíduo -, sobretudo no que tange aos critérios de legitimidade de atuação do poder punitivo estatal, conforme se verá a seguir.

\subsection{Estado Constitucional e Democrático de Direito e Direito Penal}

O Direito Penal é certamente um dos ramos do Direito mais sensíveis ao modelo de Estado adotado. As respostas às basilares perguntas do por que, quando e como punir ${ }^{96}$ dependem diretamente da forma como está desenhada a relação Estado-indivíduo ${ }^{97}$.

Passa-se, pois, neste momento, prescindindo-se de uma análise histórico-evolutiva demasiadamente detalhada ${ }^{98}$, a se analisar como o Direito Penal se coloca no atual modelo de Estado Constitucional e Democrático de Direito.

\footnotetext{
${ }^{95}$ Luigi Ferrajoli salienta que não mais o direito se subordina à política, mas sim a política deve subordina-se ao direito, ou seja, aos vínculos positivos e negativos impostos pela Constituição. (Cf. FERRAJOLI, Luigi. Democracia y garantismo, cit., p. 32; Id. Pasado y futuro del Estado de derecho, cit., p. 19; Id. Sobre el papel cívico y político de la ciencia penal en el Estado constitucional de derecho, cit., p. 68-71).

${ }^{96}$ FERRAJOLI, Luigi. Direito e razão: teoria do garantismo penal, cit., p. 216-220.

97، “Como a própria história demonstra, não só a compreensão do ilícito sempre disse muito sobre o modelo de Estado em que é implementada, como o Modelo de Estado sobre a acepção de ilicitude que recepciona." (D’ÁVILA, Fábio Roberto. Ofensividade em direito penal: escritos sobre a teoria do crime como ofensa a bens jurídicos. Porto Alegre: Livr. do Advogado, 2009. p. 51).

${ }^{98}$ Para uma perspectiva histórica do poder punitivo, destacando a sua íntima relação com o modelo de Estado e com as concepções políticas, cf., p. ex., MIR PUIG, Santiago. Constitución, derecho penal y globalización, cit., p. 115-126. Para uma postura crítica contundente, cf. ZAFFARONI, Eugenio Raúl; BATISTA, Nilo. Direito penal brasileiro,cit., v. 1, p. 29-83.
} 
Sabe-se, como já dito, que o poder punitivo estatal, ao menos da forma como hoje se concebe, surge com o próprio nascimento dos Estados nacionais modernos. A unificação do centro de poder também significou a assunção do monopólio do exercício da violência legítima - com a neutralização da figura da vítima e da própria ideia de vingança privada -, o qual, inicialmente, foi exercido de modo arbitrário e praticamente ilimitado.

As ideias de limitação do poder punitivo estatal desenvolveram-se principalmente com o movimento iluminista, a partir do século XVIII, e foram sendo incorporadas, pouco a pouco, já no âmbito do Estado de Direito, com inúmeras variações e algumas evoluções, nas Declarações de Direito, nas diversas legislações ${ }^{99}$ e nas Constituições que se seguiram até os dias de hoje, em um longo caminho - ainda em curso - de passagem de um Direito Penal legal-autoritário para um Direito Penal Constitucional-Democrático.

Assim, o que se observa é que é exatamente no contexto iluminista de construção do Estado de Direito que surge grande parte dos princípios que se afiguram fundamentalmente como limitadores ao poder punitivo estatal ${ }^{100}$. Princípios como o da legalidade, da proporcionalidade, da culpabilidade e da humanidade das penas são alguns dos que possuem raízes no período iluminista. Ainda associado ao Iluminismo, já no século XIX, verifica-se o nascimento da figura do bem jurídico-penal, também com função limitadora do poder punitivo ${ }^{101}$.

\footnotetext{
${ }^{99}$ Vale lembrar que é também nesse contexto iluminista do século XVIII que surgem os primeiros Códigos Penais.

${ }^{100}$ Neste ponto, merece destaque, dentre muitas outras, a clássica obra de Cesare Beccaria: Dos delitos e das penas, de 1764. São Paulo: Ed. Revista dos Tribunais, 2006. Ferrajoli lembra que "fue justamente el Derecho Penal el terreno en el que, durante los siglos XVII y XVIII, la gran filosofia politica del jusnaturalismo racionalista - de Hobbes a Locke, de Thomasus y Pufendorf a Mostequieu y Voltaire, hasta Beccaria, Benthan, Filangieri y Romagnosi - libró sus bastallas contra el despotismo repressivo e inquisitivo próprio del ancien regime y fue definiendo los valores dela civilizacíon jurídica moderna y las líneas maetras de Estado de derecho: el respeto a la persona humana, los valores de la vida y de la liberdad personal, el nexo entre legalidade y liberdad, la tolerância y la libertad de consciência y de expresíon, la concepcion del derecho y del Estado como artifícios cuya legetimacíon depende del cumplimiento de sus funiones de tutela de los derechos de los ciudadanos." (FERRAJOLI, Luigi. Sobre el papel cívico y político de la ciencia penal en el Estado constitucional de derecho, cit., p. 64). Acerca da importância do Iluminismo para o Direito Penal atual, cf. HASSEMER, Winfried. Direito penal: fundamentos, estrutura e política. Porto Alegre: Safe, 2008. p. 34-38.

${ }^{101}$ PRADO, Luis Regis. Bem jurídico-penal e Constituição, cit. Afirmando a imprescindibilidade do bem jurídico - apontado como "herança do Iluminismo" - como "núcleo negativo e crítico do Direito Penal", cf. BECHARA, Ana Elisa Liberatore Silva. Delitos sem bens jurídicos? Boletim IBCCRIM, São Paulo, ano 15, n. 181, p. 4-5, dez. 2007. No mesmo sentido, ROXIN, Claus. Sobre o recente debate em torno do bem jurídico. In: GRECO, Luís; TÓRTIMA, Fernanda Lara (Orgs.). O bem jurídico como limitação ao poder estatal de incriminar? Rio de Janeiro: Lumen Juris, 2011. p. 185. Cf, ainda, afirmando que "não há crime (legítimo) sem ofensa a um bem jurídico-penal”, D’ÁVILA, Fábio Roberto. op. cit., p. 51.
} 
Sabe-se, porém, que as garantias contra o poder punitivo estatal foram, inicialmente, em um modelo de Estado Legal de Direito, inseridas unicamente em legislações ou em Constituições que representavam meras cartas políticas de intenções, destituídas de força normativa, de um sistema de controle de constitucionalidade efetivo, e de procedimentos dificultados para a sua modificação, cenário que foi modificado com a passagem para o Estado Constitucional de Direito e com a evolução da doutrina constitucional.

No atual modelo de Estado Constitucional de Direito, com sua estrutura de vinculação normativa, o Direito Penal - assim como todos os demais ramos do Direito passa a encontrar o seu fundamento na Constituição ${ }^{102}$. Isso significa que todos os seus institutos e normas devem ser lidos, interpretados e (re)construídos a partir da Constituição, devendo ser descartado o que com ela for incompatível ${ }^{103}$. Verifica-se a chamada constitucionalização do Direito Penal, a construção de um verdadeiro Direito Penal Constitucional em lugar de um Direito Penal de base normativa apenas legal, codificada, infraconstitucional ${ }^{104}$.

No que concerne ao conteúdo de suas normas, o Direito Penal - após sofrer variações nos modelos de Estado Liberal e Social ${ }^{105}$ - está obrigatoriamente vinculado aos valores, finalidades e objetivos do Estado Democrático de Direito, revelados pelas cartas constitucionais. Apresenta-se, portanto - até mesmo por se tratar da mais sensível

\footnotetext{
${ }^{102}$ Nesse sentido, Luigi Ferrajoli afirma que, no Direito Penal, "todas las respuestas a las clássicas cuestiones relativas a su legitimacíon - cuándo y como castigar, cúando y como proibir, cúando y como juzgar resultan condicionadas ahora por los princípios garantistas sancionados em la constituicíon: lesividade y materialidade de los delitos, culpabilidade, garantias del juicio oral, car acusatória de la prueba y derechos de la defensa, que han dejado de ser simples princípios teóricos para convertirse en normas jurídicas vinculantes para el legislador." (Sobre el papel cívico y político de la ciencia penal en el Estado constitucional de derecho, cit., p. 68).

${ }^{103}$ Nesse sentido, Miguel Reale Júnior, em tópico referente à ancoragem constitucional, ressalta que "defluem (...) do texto constitucional princípios fundamentais do Direito Penal", destacando que "o Direito Penal esta limitado negativamente pela Constituição, devendo ater-se a estes princípios, não violando valores constitucionais, mas sim por eles pautando-se. Do contrário, a norma seria inconstitucional." (Instituições de direito penal, cit., p. 26-27).

${ }^{104}$ PALAZZO, Francesco. Estado constitucional de derecho y derecho penal, cit., p. 59.

${ }^{105}$ Passou-se de um Direito Penal voltado para os direitos do cidadão contra os abusos do poder do Estado, no modelo Liberal, a um Direito Penal mais preocupado com uma eficiente luta contra o crime, instrumento de implantação de políticas sociais, no modelo Social. Cf. MIR PUIG, Santiago. Constitución, derecho penal y globalización, cit., p. 117-121. Id. La nueva constitución española y el derecho penal: fundamento constitucional de la pena y teoría del delito, cit., p. 528-533. BECHARA, Ana Elisa Liberatore Silva. Da teoria do bem jurídico como critério de legitimidade do direito penal, cit., p. 28-33 e p. 63-64. FERRAJOLI, Luigi. Sobre el papel cívico y político de la ciencia penal en el Estado constitucional de derecho, cit., p. 65.
} 
relação entre Estado-cidadão - fundamentalmente como garantidor da liberdade humana ${ }^{106}$, com raízes predominantemente liberais ${ }^{107}$.

Assim, no âmbito do modelo de Estado Democrático de Direito, consagrador, como visto, de um Estado pluralista, laico e inspirado em valores de tolerância, fundado na dignidade humana e garantidor de conjunto de direitos fundamentais invioláveis, o Direito Penal apresenta como base de justificação e de legitimidade a afirmação da autonomia e do livre desenvolvimento do indivíduo ${ }^{108}$. É a pessoa, nesta perspectiva, a destinatária da norma penal, e não a coletividade ou o próprio Estado ${ }^{109}$. A dignidade humana, fundamento da República, coloca o indivíduo na posição central, vedando a sua instrumentalização para qualquer finalidade. Assim, deve o Estado servir ao indivíduo, e não o indivíduo servir às finalidades alegadas pelo Estado.

Diante disso, pode-se dizer que na maior parte dos países que incorporam o modelo de Estado Democrático de Direito - seja com esta ou outra denominação - as Constituições acabam por se revelar como o principal instrumento de limitação do poder punitivo estatal, uma vez que os princípios iluministas limitadores - agora preenchidos

\footnotetext{
${ }^{106}$ Nesse sentido, advertência de Luiz Regis Prado de que "a lei penal (...) atua, não como limite da liberdade pessoal, mas sim como seu garante". (Bem jurídico-penal e Constituição, cit., p. 99). Ana Elisa Liberatore Silva Bechara, ressaltando ser o Direito Penal "um sistema jurídico voltado à própria proteção do indivíduo diante da intervenção do Estado", leciona que, "ao estabelecer valores, interesses, garantias, a Constituição Federal não se dirige originalmente à regulamentação do comportamento dos cidadãos entre si, e sim ao reconhecimento de limitações fundamentais ao exercício do poder político do Estado. A referência expressa a direitos e bens no texto constitucional tem, portanto, por objetivo primordial sua fixação como limite a ser respeitado pelo poder público, não sendo possível transportá-los automaticamente à esfera penal para efeito de criar tipos ou mecanismos de imputação que atinjam excessivamente os próprios direitos fundamentais do agente. (BECHARA, Ana Elisa Liberatore Silva. Direitos humanos e direito penal: limites da intervenção penal racional no Estado Democrático de Direito. In: MENDES, Gilmar Ferreira; BOTTINI, Pierpaolo Cruz; PACELLI, Eugenio (Coords.). Direito penal contemporâneo: questões controvertidas. São Paulo: Saraiva, 2011. p. 153-194). Francesco Palazzo aponta a necessidade de se considerar o Direito Penal também como instrumento de liberdade individual, contra agressões provenientes do Estado ou de particulares. (Valores constitucionais e direito penal, cit., p. 18). Combatendo a ingerência estatal indevida por meio do direito penal no Estado Democrático de Direito, cf. PASCHOAL, Janaína Conceição. Ingerência indevida: os crimes comissivos por omissão e o controle da punição do não fazer. Porto Alegre: Safe, 2011.

${ }^{107}$ Destacando a relevância do caráter liberal, MIR PUIG, Santiago. Constitución, derecho penal y globalización, cit. Cf., também, PASCHOAL, Janaina Conceição. Constituição, criminalização e direito penal mínimo. São Paulo: Ed. Revista dos Tribunais, 2003. p. 128-135.

${ }^{108}$ BECHARA, Ana Elisa Liberatore Silva. Da teoria do bem jurídico como critério de legitimidade do direito penal, cit. e Id. Direitos humanos e direito penal: limites da intervenção penal racional no Estado Democrático de Direito, cit. "Em um Estado Democrático de Direito, modelo teórico de Estado que eu tomo por base, as normas jurídico-penais devem perserguir somente o objetivo de assegurar aos cidadãos uma coexistência pacífica e livre, sob a garantia de todos os direitos humanos". (ROXIN, Claus. A proteção de bens jurídicos como função do direito penal. 2. ed. Porto Alegre: Livr. do Advogado, 2009. p. 17).

${ }^{109}$ BECHARA, Ana Elisa Liberatore Silva. Da teoria do bem jurídico como critério de legitimidade do direito penal, cit. e Id. Direitos humanos e direito penal: limites da intervenção penal racional no Estado Democrático de Direito, cit.
} 
com conteúdo democrático ${ }^{110}$ - passam a integrar Constituições detentoras de força normativa imediata, típica dos Estados Constitucionais ${ }^{111}$. Além disso, a própria concepção de bem jurídico passa a buscar seu fundamento no texto constitucional ${ }^{112}$.

Vale lembrar, nesse sentido, que a própria existência de uma Constituição já traz consigo a ideia de conformidade e limitação do poder do Estado, incluindo aí o poder punitivo. O exercício puro e simples do poder, por quem quer que seja, prescindiria de sistema normativo, reservando-se ao livre jogo de forças e ao arbítrio. Daí emana a conclusão de que o sistema normativo constitucional não pode ser outra coisa que não um instrumento limitação e conformação do poder estatal, e, claro, especialmente do poder estatal de punir.

Tal sistema normativo constitucional tem, portanto, o condão de vincular - formal e materialmente - o legislador, o juiz penal e todos os agentes públicos pelos quais o Estado exerce o seu poder punitivo, os quais devem, ainda que contra a vontade circunstancial da maioria, atuar em respeito a estes princípios fundamentais limitadores os quais se revelam, na realidade, como critérios mínimos de legitimidade da intervenção estatal $^{113}$-, sob pena de inconstitucionalidade.

Dessa forma, verifica-se que, no âmbito da política criminal, deve o legislador pautar-se pela Constituição, a qual deve servir de guia notadamente para o processo de criminalização e descriminalização de $\operatorname{condutas}^{114}$. Para selecionar o que deve ou não

\footnotetext{
${ }^{110}$ BECHARA, Ana Elisa Liberatore Silva. Da teoria do bem jurídico como critério de legitimidade do direito penal, cit. p. 64.

111،Num contexto democrático e pluralista, a força normativa da Constituição em relação ao direito penal deve voltar-se à sua limitação, sem sentido negativo, e não à sua fundamentação, pela forma de determinação." (BECHARA, Ana Elisa Liberatore Silva. Da teoria do bem jurídico como critério de legitimidade do direito penal, cit. p. 409-410).

${ }^{112}$ A esse respeito, cf. PASCHOAL, Janaina Conceição. Constituição, criminalização e direito penal mínimo, cit., p. 49-69. Para uma visão completa do bem jurídico-penal, destacando a sua base constitucional e a sua função de limitação do poder punitivo estatal, como parâmetro negativo de legitimação, cf., entre muitos outros, BECHARA, Ana Elisa Liberatore Silva. Da teoria do bem jurídico como critério de legitimidade do direito penal, cit. PRADO, Luis Regis. Bem jurídico-penal e Constituição, cit. MARINUCCI, Giorgio; DOLCINI, Emilio. Constituição e escolhas de bens jurídicos. Revista Portuguesa de Ciência Criminal, Coimbra, v. 4, n. 2, p. 151-198, abr.jun. 1994. ROXIN, Claus. A proteção de bens jurídicos como função do direito penal, cit. D’ÁVILA, Fábio Roberto. op. cit. Para uma visão panorâmica do atual debate acerca do bem jurídico na doutrina alemã, destacando posições divergentes, cf. GRECO, Luís; TÓRTIMA, Fernanda Lara (Orgs.). op. cit. Cf, ainda, HEFENDEHL, Roland (Ed.). La teoría del bien jurídico: fundamento de legitimación del derecho penal o juego de abalorios dogmático? Madrid: Marcial Pons, 2007.

${ }^{113}$ BECHARA, Ana Elisa Liberatore Silva. Direitos humanos e direito penal: limites da intervenção penal racional no Estado Democrático de Direito, cit., p. 190.

114“Afinal, não podemos opor limites ao legislador com a mera alegação de que esses limites decorrem de nossa própria concepção político-criminal. A única instância que está acima do legislador é a Constituição. O limite à intervenção do legislador tem de poder reconduzir-se a ela, se ele quiser ser mais do que mera
} 
merecer a intervenção penal, o legislador ordinário deve necessariamente levar em conta os princípios penais que são as vigas mestras - fundantes e regentes - de todo o ordenamento penal. ${ }^{115}$ Deve, pois, a Constituição atuar, ao mesmo tempo, como limite negativo, impossibilitando a criminalização contrária às normas constitucionais, e como limite positivo, determinando que toda criminalização, necessariamente, represente uma ofensa a valor constitucionalmente relevante ${ }^{116}$.

No âmbito do Judiciário, deve o juiz penal, a todo o momento, aplicar diretamente os princípios constitucionais, exercendo, ainda, um papel fundamental de crítico da legislação infraconstitucional ${ }^{117}$, aplicando somente normas que se revelem constitucionais ou atribuindo-lhes interpretação conforme a Constituição ${ }^{118}$. Nesse sentido, o próprio princípio da legalidade deve ser reformulado, passando de nulla crimen sine lege para nulla crimen sine lege constitucionalmente válida ${ }^{119}$.

Além disso, a própria dogmática penal deve ser (re)pensada a partir de bases constitucionais, com a adequação ou até mesmo coma a criação de institutos e instrumentos que permitam a concretização dos princípios constitucionais aplicáveis na

expressão de uma opinião pessoal" (ROXIN, Claus. Sobre o recente debate em torno do bem jurídico, cit., p. 184). Existe um interessante debate acerca dos mandados constitucionais expressos de criminalização, havendo quem defenda a obrigatoriedade de obediência ao comando da Constituição pelo legislador (cf., p. ex,. FELDENS, Luciano. A Constituição penal: a dupla face da proporcionalidade no controle de normas penais, cit., p. 36 e seg. PALAZZO, Francesco. Valores constitucionais e direito penal, cit., p. 103-115) e quem, ao contrário, argumente que o legislador é livre para avaliar a efetiva necessidade de enquadramento penal mesmo em caso de uma determinação expressa da Constituição. (cf., p. ex., PASCHOAL, Janaina Conceição. Constituição, criminalização e direito penal mínimo, cit., p. 114. Id. Ingerência indevida: os crimes comissivos por omissão e o controle da punição do não fazer, cit., p. 151. BECHARA, Ana Elisa Liberatore Silva. Da teoria do bem jurídico como critério de legitimidade do direito penal, cit., p. 41-56. MARINUCCI, Giorgio; DOLCINI, Emilio. op. cit., p. 171-190). Na jurisprudência, cf. STF - HC $n^{\circ}$ 104.410/RS. Rel. Min. Gilmar Mendes. j.06/03/2012.

${ }^{115}$ PRADO, Luis Regis. Bem jurídico-penal e Constituição, cit., p. 55.

${ }^{116}$ BECHARA, Ana Elisa Liberatore Silva. Da teoria do bem jurídico como critério de legitimidade do direito penal, cit., p. 47. Sobre o tema, cf., colocando a Constituição apenas como limite negativo ao legislador, MARINUCCI, Giorgio; DOLCINI, Emilio. op. cit., p. 164-170.

${ }^{117}$ Ressaltando o papel do juiz como garantidor dos direitos fundamentais consagrados na Constituição, cf. FRANCO, Alberto Silva; STOCO, Rui (Coords.). Código Penal e sua interpretação. São Paulo: Ed. Revista dos Tribunais, 2007. p. 60-63. Sobre a relação do juiz com o poder punitivo, Eugênio Raúl Zaffaroni e Nilo Batista afirmam que "a mais óbvia função dos juízes penais e do direito penal como planejamento das decisões judiciais é a contenção do poder punitivo. Sem a contenção jurídica (judicial) o poder punitivo ficaria liberado ao puro impulso das agências executivas e políticas e, por conseguinte, desapareceriam o estado de direito e a própria república" (ZAFFARONI, Eugenio Raúl; BATISTA, Nilo. Direito penal brasileiro,cit., v. 1, p. 40).

${ }^{118}$ FERRAJOLI, Luigi. Democracia y garantismo, cit., p. 31.

${ }^{119}$ Cf. FERRAJOLI, Luigi. Direito e razão: teoria do garantismo penal, cit., p. 808; Id. Pasado y futuro del Estado de derecho, cit., p. 18; Id. Sobre el papel cívico y político de la ciencia penal en el Estado constitucional de derech, cit., p. 69). 
seara penal ${ }^{120}$. Toda a ciência penal deve, ainda, exercer um papel de crítica do direito existente, procedendo a um contínuo exame de validez constitucional e propondo a correção dos problemas identificados ${ }^{121}$.

Fácil é concluir, pois, que, no Estado Constitucional e Democrático de Direito, toda a atividade de atuação do poder punitivo estatal encontra-se limitada pelas normas constitucionais. Constitui-se, assim, um verdadeiro sistema presidido pela Constituição ${ }^{122}$, baseado em valores materiais dela constantes.

No Brasil, por mais óbvia que tal afirmação possa parecer, embora existam avanços notáveis $^{123}$, inúmeros estudiosos e profissionais que atuam neste setor específico do Direito parecem simplesmente ignorá-la Com efeito, continua-se, predominantemente, a estudar e a aplicar um Direito Penal de base eminentemente legal, codificada, muitas vezes de caráter autoritário - Direito Penal legal-autoritário - que, talvez amparado em reclames punitivistas irracionais fomentados por uma mídia acrítica ou mal intencionada $^{124}$, ainda resiste bravamente ao novo modelo de Estado e de constitucionalismo que propugna por um Direito Penal fundado na constituição e, portanto, amparado em valores democráticos - Direito Penal ConstitucionalDemocrático. Passados mais de 20 anos da entrada em vigor da Constituição brasileira de 1988, ainda há muito por fazer. O que se observa é que a efetivação das disposições constitucionais - no contexto de constitucionalização do Direito - ocorre de maneira lenta

\footnotetext{
${ }^{120}$ Nesse sentido, Ricardo Guastini defende que, no contexto da constitucionalização do Direito, a Constituição também deve condicionar "el estilo doctrinal" (La "Constitucionalizacíon” del Ordenamiento Jurídico: el Caso Italiano, cit., p. 49.). Cf., ainda, Santiago Mir Puig (Revisión de la teoría del delito en un estado social y democrático de derecho, cit.), para quem as teorias da pena e do delito devem basear-se na concepção do Direito Penal no Estado Social y Democrático de Direito, ressaltando a existência, no Estado Constitucional, de um fundamento constitucional da pena e da teoria do delito. Segundo Mir Puig, "no solo la pena, sino tambíen el delito han de encontrar, pues, su fundamento em la concepcíon del Estado social y democrático de derecho, que se convierte así en el soporte (valorativo) de los dos pilares sobre los cuales gravita todo el sistema (teleológico) de la Parte General del derecho penal." (La nueva constitución española y el derecho penal: fundamento constitucional de la pena y teoría del delito, cit., p. 526).

${ }^{121}$ FERRAJOLI, Luigi. Sobre el papel cívico y político de la ciencia penal en el Estado constitucional de derecho, cit., p. 70; Id. Democracia y garantismo, cit., p. 31. Em sentido semelhante, destacando o papel da dogmática e dos valores constitucionais como limite também ao subjetivismo judicial, cf. REALE JÚNIOR, Miguel. Razão e subjetividade no direito penal. Revista da Associação Brasileira de Professores de Ciências Penais, São Paulo, v. 1, n. 0, p. 226-249, jan./jun. 2004.

${ }^{122}$ BECHARA, Ana Elisa Liberatore Silva. Da teoria do bem jurídico como critério de legitimidade do direito penal, cit., p. 42.

${ }^{123}$ Vide, p. ex, STJ HC 197.601/RJ. Rel.Min.Maria Thereza de Assis Moura. j.28/06/2011, que, em sua ementa, traz a afirmação de que "o Direito Penal deve ser encarado de acordo com a principiologia constitucional."

${ }^{124}$ Sobre a relação ente mídia e sistema penal, cf. BATISTA, Nilo. Mídia e sistema penal no capitalismo tardio. Discursos Sediciosos, Rio de Janeiro, v. 12, n. 12, p. 271-289, 2002.
} 
e gradual, sobretudo quando se considera tratar-se de um texto que representa substancial ruptura com a ordem anterior.

Vale ressaltar que a Constituição Federal brasileira de 1988, incorporando um modelo de Estado Constitucional e Democrático de Direito, consagrou inúmeros princípios aplicáveis em matéria penal, inseridos num extenso rol de direitos e garantias fundamentais de aplicação imediata $\left(\operatorname{art.} 5^{\circ}, \S 1^{\circ}\right.$ ), o qual acaba por desenhar um modelo de intervenção penal mínima ${ }^{125}$, colocando-se, essencialmente, como referência de limitação do poder punitivo ${ }^{126}$.

Essa limitação se dá por meio de princípios constitucionais explícitos - princípio da legalidade e da igualdade, por exemplo - e implícitos - princípio da ofensividade e da intervenção penal mínima, por exemplo. Enquanto os primeiros estão claramente expressos em dispositivos do texto constitucional, os segundos, embora não escritos, decorrem dos próprios princípios explícitos ou mesmo do regime de limitação do poder punitivo adotado, seguindo o disposto no $\operatorname{art.~}^{\circ}, \S 2^{\circ}$, da Constituição ${ }^{127}$. Há, ainda, aqueles princípios constantes de tratados internacionais dos quais o país é signatário e que são incorporados ao ordenamento com status de norma constitucional, nos termos do art. $5^{\circ}, \S 3^{\circ}$, da Constituição.

Dentre tais princípios, há aqueles exclusivamente penais, como o da humanidade das penas, e outros de aplicação geral, como o da dignidade humana ou da proporcionalidade ${ }^{128}$.

No plano infraconstitucional, importante mencionar que a Parte Especial do Código Penal brasileiro em vigor data de 1940, período vetusto e autoritário, tendo sido elaborado sob forte influência do também autoritário Código Rocco italiano de $1930^{129}$. A Parte Geral em vigor, embora tenha passado por ampla reforma em 1984, também permanece com redação produzida anteriormente à Constituição de 1988.

\footnotetext{
${ }^{125} \mathrm{O}$ princípio da intervenção penal mínima determina que a atuação do poder punitivo estatal somente se legitima como última alternativa, e somente quando envolver ataques a bem jurídicos fundamentais Acerca de tal princípio, adotado implicitamente pela Constituição brasileira de 1988, cf., BATISTA, Nilo. Introdução crítica ao direito penal brasileiro. 11. ed. Rio de Janeiro: Revan, 2007. p. 84-90. LUISI, Luiz. Os princípios constitucionais penais. 2. ed. Porto Alegre: Safe, 2003. p. 38-46.

${ }^{126}$ Nesse sentido, a lição de Janaína Paschoal, para quem "tal qual ocorre com a lei penal, a Constituição Federal revela-se um limite ao poder punitivo estatal, sendo desse limite impossível abdicar". (Constituição, criminalização e direito penal mínimo, cit., p. 148).

${ }^{127}$ FRANCO, Alberto Silva; STOCO, Rui (Coords.). op. cit., p. 37 e seg. LUISI, Luiz. op. cit., p. 13.

${ }^{128}$ Palazzo fala em princípios de direito penal constitucional e em princípios constitucionais influentes em matéria penal. (Valores constitucionais e direito penal, cit., p. 22-26). Da mesma forma, LUISI, Luiz. op. cit.

${ }^{129}$ Cf. MARINUCCI, Giorgio; DOLCINI, Emilio. Manuale di diritto penale. 3. ed. Milano: Giuffrè, 2009. p. 20 e seg. PALAZZO, Francesco. Direito penal e Constituição na experiência italiana. Revista Portuguesa de Ciência Criminal, Coimbra, v. 9, n. 1, p. 31 e seg. jan./mar. 1999. Vale ressalvar, todavia, que ao longo destas várias décadas, o texto da Parte Especial do Código Penal brasileiro sofreu diversas alterações pontuais.
} 
À semelhança da Itália, onde até hoje a Constituição de 1948 convive com o Código Rocco de 1930 - significativa expressão legislativa fascista -, pode-se dizer que o Brasil vivencia um verdadeiro "dualismo antinômico", em que os valores autoritários e moralistas do Código Penal de 1940 se confrontam com os valores liberais e democráticos da Constituição de $1988^{130}$.

A partir da década de 1990, foram editadas, no Brasil, diversas leis especiais em matéria penal, com a criação de crimes ligados a valores supra-individuais consagrados no texto de 1988, como a ordem econômica, o sistema financeiro nacional, o meio ambiente, as relações de consumo ${ }^{131}$. O que se observa, no entanto, é uma parcial e interessada "adequação" do Direito Penal à Constituição, unicamente com o escopo de expansão do poder punitivo estatal, olvidando-se do modelo de intervenção penal mínima desenhado pelo mesmo texto constitucional e de princípios limitadores dele decorrente, como o da subsidiariedade, ofensividade e fragmentariedade ${ }^{132}$.

Registre-se que muitas dessas leis especiais - e também de leis que alteraram a Parte Especial do Código Penal - foram motivadas por episódios circunstanciais típicos de período eleitoral ${ }^{133}$, em um suspeito ambiente de "emergência"134, e, valendo-se

\footnotetext{
${ }^{130}$ Acerca da experiência italiana, cf. PALAZZO, Francesco. Valores constitucionais e direito penal, cit., p. 16-22. Id. Direito penal e Constituição na experiência italiana, cit., p. 31 e seg. $\mathrm{O}$ autor chega a afirmar que essa coexistência entre duas fontes antinômicas tem algo de paradoxal, sobretudo tendo em consideração a sua já longuíssima duração.

${ }^{131}$ Muitos autores atribuem esse fenômeno à manifestação da faceta social do Estado de Direito. Nesse sentido, p. ex. LUISI, Luiz. op. cit.

${ }^{132}$ Janaína Paschoal lembra, citando Moreno Hernandez, que as medidas de endurecimento penal se mostram frequentemente incompatíveis com um sistema penal qualificado como democrático, tal qual exige o Estado Democrático de Direito, aproximando-se mais de um Estado totalitário, em que os indivíduos vivem sob um terror penal, sob o pretexto de que as medidas são totalmente justificáveis (Constituição, criminalização e direito penal mínimo, cit., p. 132-133).

${ }^{133}$ Para uma análise crítica desse cenário, cf. FRANCO, Alberto Silva. Crimes hediondos. 6. ed. rev. atual. e ampl. São Paulo: Ed. Revista dos Tribunais, 2007. REALE JÚNIOR, Miguel. A inconstitucionalidade da lei dos remédios. Revista dos Tribunais, São Paulo, v. 88, n. 763, p. 415-431, 1999. Id. Caminhos do direito penal brasileiro. Revista Brasileira de Ciências Criminais, São Paulo, v. 18, n. 85, p. 41-76, jul./ago. 2010.

${ }^{134}$ Acerca da relação entre emergência e Direito Penal cf. MOCCIA, Sergio. Emergência e defesa dos direitos fundamentais. Revista Brasileira de Ciências Criminais, São Paulo, v. 7, n. 25, p. 58-91, jan./mar. 1999. Segundo o autor italiano, "o emergencialismo (...) gerou o uso simbólico do direito penal em nome de uma presumida política criminal da eficiência, que acabou por suplantar a busca de soluções de política social geral bem mais eficientes." (p. 62). Nessa linha, a lição de Zaffaroni: "Todo problema social vira problema penal: a droga, a violência, a psiquiatria, tudo vira penal, tudo. Nada acontece sem que algum legislador, algum deputado, algum senador não faça um projeto de lei penal. Não vão fazer projetos de leis administrativas. É mais complicado. Mas, lei penal qualquer idiota faz um projeto e uma mensagem ainda mais idiota que o projeto. Isso é muito barato. A lei penal não custa. $\mathrm{E}$ o sujeito tem cinco minutos na televisão. Para a vida e para a presença de um político isso é imprescindível". (Conferência Ministro Eugenio Raúl Zaffaroni. In: KARAM, Maria Lúcia (Org.). Globalização, sistema penal e ameaças ao Estado Democrático de Direito. Rio de Janeiro: Lumen Juris, 2005. p. 24).
} 
muitas vezes de um aparentemente retórico argumento de inspiração constitucional ${ }^{135}$, na realidade, contribuíram mais para a formação de um corpo legislativo caótico, disforme, retalhado e frequentemente violador do modelo constitucional vigente ${ }^{136}$.

Verifica-se, portanto, sob a justificativa de uma pretensa necessidade de defesa social, uma tendência de verdadeira expansão do poder punitivo estatal ${ }^{137}$, tanto em seu aspecto horizontal - com a sua atuação no âmbito novos setores sociais - quanto em seu aspecto vertical - com o incremento de penas para delitos já existentes. Ocorre que tal expansão muitas vezes se dá com a violação aos princípios fundamentais de base liberal, em nome de uma aventada eficácia na proteção do corpo social ${ }^{138}$.

Paralelamente, observa-se que a atuação do legislador na revogação de tipos penais contrários à nova ordem constitucional se mostrou sempre atrasada, tímida, e pouco eficiente. Para se ter uma ideia, os crimes de adultério, de sedução e de rapto permaneceram no Código Penal brasileiro até o ano de 2005. Além disso, crimes como o de mediação para servir à lascívia de outrem, o de casa de prostituição, e as contravenções de vadiagem e embriaguez continuam em vigor. O uso de drogas, embora tenha sofrido significativa modificação no ano de 2006, permanece como conduta criminosa. ${ }^{139}$.

Seja como for, diante de todo esse cenário de construção e consolidação de um novo modelo de Estado e de inércia do Legislativo, chama bastante atenção o fato de o Supremo Tribunal Federal jamais ter declarado a inconstitucionalidade do preceito

\footnotetext{
${ }^{135}$ PALAZZO, Francesco. Direito penal e Constituição na experiência italiana, cit., p. 34-35.

${ }^{136}$ Por essa razão, Miguel Reale Júnior chega a sugerir a realização de um trabalho de "Consolidação das normas penais" (Caminhos do direito penal brasileiro, cit., p. 75-76). Luigi Ferrajoli, verificando ser a inflação legislativa penal um problema global, vai mais longe e sugere a substituição do simples princípio de reserva de lei para uma reserva de código, como forma de extirpar a crise por que passa o princípio da legalidade e seu papel de garantia. (FERRAJOLI, Luigi. Pasado y futuro del Estado de derecho, cit., p. 23; Id. Democracia y garantismo, cit., p. 228-233). Para uma abordagem diferenciada da política criminal brasileira, cf. CAMPOS, Marcelo da Silveira. Crime e Congresso Nacional: uma análise da política criminal aprovada de 1989 a 2006. São Paulo: IBCCRIM, 2010.

${ }^{137}$ Sobre o tema da expansão do Direito Penal, cf. SILVA SÁNCHEZ, Jésus-Maria. A expansão do direito penal. 2. ed. São Paulo: Ed. Revista dos Tribunais, 2011. MIR PUIG, Santiago. Constitución, derecho penal y globalización, cit.

${ }^{138}$ Para uma análise crítica dessa situação, cf. BECHARA, Ana Elisa Liberatore Silva. Direitos humanos e direito penal: limites da intervenção penal racional no Estado Democrático de Direito, cit.

${ }^{139}$ Para uma visão geral comparativa do processo de descriminalização impulsionado pelas Constituições democráticas na Espanha, Alemanha e Itália, cf. PALAZZO, Francesco. Valores constitucionais e direito penal, cit., p. 90-103.
} 
primário de um tipo penal ${ }^{140}$, valendo-se, em grande parte das vezes, do anacrônico argumento de que somente uma lei pode revogar outra lei sob pena de violação do princípio da separação dos poderes, e ignorando, por razões obscuras, o sistema de vinculação normativa propugnado pelo vigente modelo de Estado Constitucional ${ }^{141}$. Interessante observar que, muito embora envolva uma forma muito menos gravosa de intervenção na esfera individual da pessoa, este mesmo raciocínio não é utilizado, por exemplo, por ocasião da análise da adequação à Constituição de espécies tributárias, sendo inúmeras as declarações de inconstitucionalidades pelo Supremo Tribunal Federal ${ }^{142}$.

No Estado Constitucional de Direito brasileiro, cabe ao Supremo Tribunal Federal exercer, em última análise, o papel de guardião da Constituição, o que, logicamente, inclui a avaliação da constitucionalidade de normas reveladoras de tipos penais. Sendo assim, não se entende a razão pela qual o STF recusa-se a exercer verdadeiramente esta função, diferentemente do que já vem ocorrendo - ainda que com dificuldades - há bastante tempo nas Cortes Supremas dos mais diversos países ${ }^{143}$.

De toda maneira, para o escopo do presente trabalho, considera-se adequada e suficiente a fixação da premissa acima desenhada, qual seja, a de que atualmente vigora no Brasil - na linha de vários países do mundo - um modelo de Estado Constitucional e Democrático de Direito, o que traz como consequência a formatação de um Direito Penal

\footnotetext{
${ }^{140}$ Ressalte-se, todavia, que o STF, valendo-se da técnica de interpretação conforme a Constituição, já declarou inconstitucionalidade de sentidos atribuídos a tipos penais. (Cf., p. ex., ADPF 187, Rel. Min.Celso de Mello. j.15/06/2011. ADPF 54. Rel Min.Marco Aurélio.j.12/04/2012). Também já declarou a inconstitucionalidade de norma penal violadora do princípio constitucional da individualização da pena. (Cf., p. ex., HC 82.959/SP. Rel.Min. Marco Aurélio. j.23/02/2006). Por meio do controle difuso de constitucionalidade, contudo, não é raro ver juízes declarando a inconstitucionalidade de tipos penais.

${ }^{141}$ Como exemplo, em recente decisão (HC 104.467/RS, Rel. Min. Carmen Lúcia. j.08/02/2011), o STF, mais uma vez, acabou por ratificar a constitucionalidade do crime de manutenção de casa de prostituição, previsto no art.229 do Código Penal, olvidando-se da diferenciação entre vigência e validade e valendo-se do seguinte trecho de acórdão anterior à Constituição de 1988, da lavra do Min.Sydney Sanches (RHC 65.391.16/101987): “Ao Ministério Público e ao Juiz competem a interpretação e a aplicação da lei, jamais a negativa de vigência. A descriminalização é tarefa do legislador e não daquele cuja missão é aplicar a lei." Em seu voto, o Min.Marco Aurélio, embora reconheça certa hipocrisia, limita-se a afirmar que " a atuação judicial é vinculada, e o tipo do artigo 229 do Código Penal está em pleno vigor”; Para uma análise da constitucionalidade deste delito, cf. cap. 4 , infra.

${ }^{142}$ Cf., p. ex., RE 233.332/RJ. Rel.Min. Ilmar Galvão. j. 10/03/1999. ADI 2.551-MC-QO. Rel. Min. Celso de Mello. j. 02/04/2003. Com todas as ressalvas relativas às especificidades de cada ramo do Direito, fica a impressão de que o legislador ordinário penal encontra, diante da Constituição, maior liberdade de atuação do que o legislador ordinário tributário.

${ }^{143}$ Ao menos desde a década de 1980, Francesco Palazzo já dizia estar "fora de discussão" a legitimidade da jurisdição constitucional para uma apreciação de teor corretivo ou derrogatório de normas incriminadoras (Valores constitucionais e direito penal, cit., p. 77-78). Para uma visão geral abreviada, cf. BARBERO SANTOS, Marino. op. cit., p. 13-24, cf. PALAZZO, Francesco. Direito penal e Constituição na experiência italiana, cit., p. 39-43. Id. Valores constitucionais e direito penal, cit., p. 92-103. MARINUCCI, Giorgio; DOLCINI, Emilio. Constituição e escolhas de bens jurídicos, cit.
} 
Constitucional-Democrático: Constitucional, porque possui a Constituição como ancoragem normativa; Democrático, porque deve se pautar nos valores, fins e objetivos do Estado Democrático de Direito.

Diante desse cenário, parte-se, agora, finalmente, para a afirmação e conceituação do princípio da autorresponsabilidade - que, como se verá, se afigura como norma constitucional de conteúdo essencialmente democrático -, para, posteriormente, nos termos propugnados pelo modelo de Estado Constitucional de Direito, descrever e avaliar o seu impacto no âmbito do Direito Penal. 


\section{PRINCÍPIO DA AUTORRESPONSABILIDADE}

\subsection{Definição e afirmação como norma constitucional}

Como demonstrado nos capítulos anteriores, o fato de um Estado adotar um modelo de Estado Democrático de Direito é carregado de significado. Trata-se de modelo fruto de longa evolução científica, síntese de modelos anteriores, decorrente da experiência, do debate de ideias e do aprendizado histórico adquirido ao longo dos séculos, ainda que não desenvolvido de forma absolutamente linear.

Longe de se afigurar mera abstração, a adoção do modelo de Estado Democrático de Direito repercute diretamente na vida de todos os cidadãos que habitam determinado território, desenhando as relações Estado-indivíduo e indivíduo-indivíduo, determinando o alcance da esfera de liberdade de cada pessoa, definindo direitos, o papel das instituições, e disciplinando questões básicas como o acesso a saúde, educação, trabalho, entre outras.

Adotar um modelo de Estado Democrático de Direito significa, sobretudo, celebrar um pacto de valores democráticos, os quais - como visto - vão muito além das implicações no sistema político-representativo. E, no modelo de Estado Constitucional, tal pacto se revela por meio de um sistema normativo, composto de regras e princípios, que devem ser observados e garantidos a todos os indivíduos, ainda que contra a vontade circunstancial da maioria ou da unanimidade dos membros da sociedade, sob pena de ruptura do modelo.

Como se sabe, em consonância com o cenário internacional, foi exatamente este o pacto realizado pelo constituinte brasileiro de 1988, culminando em um texto constitucional consagrador dos valores do Estado Democrático de Direito, revelado por suas normas explícitas e implícitas, na forma de princípios e regras.

Dentre esses princípios e regras, e, como decorrência direta da adoção do modelo de Estado Democrático de Direito, insere-se o chamado princípio da 
autorresponsabilidade $^{144}$, norma segundo a qual cada indivíduo se coloca como o único responsável por suas condutas, por suas escolhas, por sua forma de viver, desenvolvendo livremente a sua personalidade, no pleno exercício de sua autonomia. Com efeito, cada indivíduo deve ser também o único a suportar as consequências de seus próprios atos, não podendo tal responsabilidade ser atribuída a terceiros.

Reconhecer o princípio da autorresponsabilidade implica reconhecer cada indivíduo como responsável por si mesmo, plenamente capaz e crítico, apto a formar as suas próprias opiniões e convicções, conduzindo livremente o seu destino.

Tal princípio vincula-se diretamente ao direito à liberdade ${ }^{145}$, moldado no contexto de construção do Estado Liberal de Direito, estabelecendo a garantia de exercício do livre desenvolvimento da personalidade, nas suas mais variadas formas, constando de diversos documentos internacionais, desde a Declaração dos Direitos do Homem e do Cidadão de $1789 .^{146}$

Como se observa, desde o século XVIII, mostra-se presente a ideia de que liberdade de cada um encontraria limites somente na lesão a direitos de outrem, ou seja, na possibilidade de causação de um dano efetivo a direito de terceiro.

Nunca é demais lembrar que a Declaração dos Direitos do Homem e do Cidadão, elaborada no âmbito da Revolução Francesa e inspirada nos ideais iluministas, se coloca como o grande marco revolucionário da relação Estado-indivíduo, sendo, até os dias atuais, importante fonte de inspiração para todas as Constituições democráticas.

\footnotetext{
${ }^{144}$ Muitos autores trabalham com ideias bastante semelhantes, valendo-se, porém, de terminologia diversa, seja referindo-se a um princípio da autodeterminação seja afirmando um princípio da autonomia. A esse respeito, cf. CANCIO MELIÁ, Manuel. Conducta de la víctima e imputacíon objetiva em derecho penal. Bogotá: Bosch. 2001. p. 299, nota 1. Id. La exclusión de la tipicidad por la responsabilidad de la víctima: imputación a la víctima. Revista de Derecho Penal y Criminología, Madrid, n. 2, p. 79, nota 77, jul. 1998.

145، As liberdades são proclamadas partindo-se da perspectiva da pessoa humana como ser em busca de autorealização, responsável pela escolha dos meios aptos para realizar as suas potencialidades” (MENDES, Gilmar Ferreira et al. op. cit., 2008, p. 359). "O conceito de liberdade humana deve ser expresso no sentido de um poder de atuação do homem em busca de sua realização pessoal, de sua felicidade”. É boa, sob, esse aspecto, a definição de Rivero: ' a liberdade é um poder de autodeterminação, em virtude do qual o homem escolhe por si mesmo seu comportamento pessoal'. Vamos um pouco além, e propomos o conceito seguinte: liberdade consiste na possibilidade de coordenação consciente dos meios necessários à realização da felicidade pessoal." (SILVA, José Afonso da. op. cit., p. 233).

146“'Declaração dos Direitos do Homem e do Cidadão: Art. 4. ${ }^{\text {- }}$ A liberdade consiste em poder fazer tudo que não prejudique outrem: assim, o exercício dos direitos naturais de cada homem não tem por limites senão aqueles que asseguram aos outros membros da sociedade o gozo dos mesmos direitos. Estes limites apenas podem ser determinados pela lei." Cf., também, artigos XII e XXII da Declaração Universal de Direitos Humanos (1948) e art. $1^{\circ}$ e 11 da Convenção Americana de Direitos Humanos (1969).
} 
Tanto é assim que a maior parte das Constituições do período após a Segunda Guerra Mundial acabou por acolher os princípios fundamentais consagrados no texto da Declaração de 1789, dentre eles o princípio da autorresponsabilidade, ainda que implicitamente - destacando, sobretudo, o direito ao livre desenvolvimento da personalidade, a exemplo da Itália $(1948)^{147}$, Alemanha $(1949)^{148}$, Portugal $(1976)^{149}$, Espanha (1978) ${ }^{150}$, Colômbia (1991) ${ }^{151}$ e Argentina (1994) ${ }^{152}$.

No mesmo sentido, a Constituição brasileira de 1988, indubitavelmente, incorpora, implicitamente, o princípio da autorresponsabilidade, decorrente, como assentado, do próprio modelo de Estado Democrático de Direito ${ }^{153}$, podendo ser extraído da inviolabilidade dos direitos à liberdade (art. $5^{\circ}$, caput), à intimidade (art.5 $\left.5^{\circ}, \mathrm{X}\right)$ e à vida privada $\left(\operatorname{art.} 5^{\circ}, \mathrm{X}\right)$, sendo estas algumas das pedras fundamentais que permitem a existência de uma República, o que por definição, pressupõe a separação entre a coisa pública e a coisa privada.

Pode-se dizer, inclusive, que o princípio da autorresponsabilidade, expressão máxima do direito à liberdade, é concretizado em inúmeros subprincípios, como o da

\footnotetext{
147،Art.2 - La Repubblica riconosce e garantisce i diritti inviolabili dell'uomo, sia come singolo sia nelle formazioni sociali ove si svolge la sua personalità, e richiede l'adempimento dei doveri inderogabili di solidarietà politica, economica e sociale".

148،Art.2.1 - Toda persona tiene el derecho al libre desarrollo de su personalidad siempre que no viole los derechos de otra ni atente contra el orden constitucional o la ley moral."

149،Art.26.1 - A todos são reconhecidos os direitos à identidade pessoal, ao desenvolvimento da personalidade, à capacidade civil, à cidadania, ao bom nome e reputação, à imagem, à palavra, à reserva da intimidade da vida privada e familiar e à protecção legal contra quaisquer formas de discriminação."

150“Art.10.1 - La dignidad de la persona, los derechos inviolables que le son inherentes, el libre desarrollo de la personalidad, el respeto a la Ley y a los derechos de los demás son fundamento del orden político y de la paz social”.

151،Art.16 - Todas las personas tienen derecho al libre desarrollo de su personalidad sin más limitaciones que las que imponen los derechos de los damás y el orden jurídico."

152، Art.19 - Las acciones privadas de los hombres que de ningún modo ofendan al orden y a la moral pública, ni perjudiquen a un tercero, están sólo reservadas a Dios, y exentas de la autoridad de los magistrados. Ningún habitante de la Nación será obligado a hacer lo que no manda la ley, ni privado de lo que ella no prohíbe."

${ }^{153}$ Também reconhecendo a autorresponsabilidade como decorrência do Estado Democrático de Direito, cf., p. ex., TAVARES, Juarez. Teoria do crime culposo. 3. ed. Rio de Janeiro: Lumen Juris, 2009. p. 370 e seg. Id. Teoria do injusto penal. 3. ed. Belo Horizonte: Del Rey, 2003. p. 289 e seg. BECHARA, Ana Elisa Liberatore Silva. Da teoria do bem jurídico como critério de legitimidade do direito penal, cit., p. 178-179. LÓPEZ DÍAZ, Claudia. Acciones a próprio risco. Bogotá: Universidad Externado de Colombia, 2006. Partindo do art. 10.1 da Constituição espanhola - que estabelece o livre desenvolvimento da personalidade - para se chegar ao princípio da autorresponsabilidade, cf. CANCIO MELIÁ, Manuel. La exclusión de la tipicidad por la responsabilidad de la víctima: imputación a la víctima, cit., p. 78 e seg. SILVA SÁNCHEZ, Jesús María. La consideracion del comportamiento de la victima en la teoria juridica del delito. Revista Brasileira de Ciências Criminais, São Paulo, v. 9, n. 34, p. 163-194, abr./jun. 2001. Cf, ainda, MEDINA FRISANCHO, José Luis. El suicidio y la autorresponsabilidad. In: MEDINA FRISANCHO, José Luis. Eutanásia e imputación objetiva en derecho penal: una interpretación normativa de los ámbitos de responsabilidad en la decisión de la propia muerte. Lima: Ara, 2010. p. 227-272.
} 
liberdade de ação ( $\operatorname{art} .5^{\circ}$, II) e de locomoção ( $\operatorname{art} .5^{\circ}, \mathrm{XV}$ ), da livre manifestação do pensamento (art. $5^{\circ}$, IV e art.220), da liberdade de consciência e de crença (art.5\%, VI), da liberdade de crença religiosa e de convicção filosófica e política (art. $5^{\circ}$, VIII), da liberdade de expressão intelectual, artística, científica e de comunicação (art.5º IX), da liberdade de associação (art. $5^{\circ}$, XVII) e de reunião ( $\operatorname{art} .5^{\circ}$, XVI), da livre de iniciativa econômica (art.170), da liberdade de exercício de qualquer trabalho, ofício ou profissão (art. $\left.5^{\circ}, \mathrm{XIII}\right)$, e da liberdade e pluralismo no campo educacional (art.206, II e III, e art.207). ${ }^{154}$.

O princípio da autorresponsabilidade assegura a liberdade de escolhas existenciais, a liberdade de interesses e objetivos, a diversidade, independentemente de quaisquer convicções morais, filosóficas, religiosas, científicas, políticas, sexuais ou outras, afastando a possibilidade de imposição de uma forma específica de vida rotulada como supostamente "boa" ou "melhor" - por algum terceiro ou pelo Estado ${ }^{155}$. Trata-se da colocação do indivíduo efetivamente como sujeito de sua própria história, segundo as suas livres opções.

Cada indivíduo é considerado como sujeito racional, autorresponsável, capaz de valorar criticamente, determinar e alterar suas concepções, com o fim de atingir seu livre desenvolvimento, independentemente das valorações morais dominantes ${ }^{156}$. Assim, não se mostra legítimo, por exemplo, obrigar uma pessoa a seguir determinada corrente de pensamento religioso ou científico, a agir de certo modo somente porque lhe trará felicidade, a cuidar da sua própria saúde, ou a não praticar uma conduta que coloque em risco unicamente a sua vida.

O princípio da autorresponsabilidade revela a consagração de uma sociedade plural, multicultural, em todas as suas facetas, típica do Estado Democrático de Direito -

\footnotetext{
${ }^{154}$ Não se ignora a existência da expressão "sob a proteção de Deus" no preâmbulo da Constituição brasileira de 1988. Entende-se, contudo, com apoio na doutrina majoritária, que o preâmbulo não faz parte do texto constitucional, sendo, portanto, destituído de valor normativo. De qualquer forma, tal expressão mostra-se incompatível com o modelo de Estado Democrático de Direito, o qual proclama um Estado laico e garantidor da liberdade de pensamento (art. $5^{\circ}$, IV) e de crença (art. $5^{\circ}$ VI e VIII). Sobre a ausência de valor normativo do preâmbulo, cf., p.ex., MENDES, Gilmar Ferreira et al. Curso de direito constitucional. 7. ed. São Paulo: Saraiva: 2012. p. 86-87.

${ }^{155}$ Como visto acima, as Constituições da Alemanha e da Argentina, p. ex., parecem fazer referência a uma "lei moral" ou a uma "moral pública" como limites ao livre desenvolvimento da personalidade, o que, eventualmente, poderia colocar em dúvida a tese aqui sustentada, abrindo um novo caminho de estudo e de discussões. A Constituição brasileira de 1988, diferentemente, em momento algum coloca, sequer implicitamente, qualquer espécie de "moral pública" como limite à liberdade individual, razão pela qual, nos limites do presente trabalho, não se adentrará neste debate.

${ }^{156}$ BECHARA, Ana Elisa Liberatore Silva. Da teoria do bem jurídico como critério de legitimidade do direito penal, cit., p. 58.
} 
Estado este laico e defensor da tolerância perante as diferenças - garantindo a liberdade no âmbito individual, a liberdade de autodeterminação, a livre realização dos planos pessoais de cada indivíduo, e, ainda, abrindo a possibilidade de que qualquer comportamento, ideia, tendência ou padrão minoritário ou supostamente "ruim" se torne, um dia, majoritário.

Há, ainda, quem sustente a relação do princípio da autorresponsabilidade também com o princípio da dignidade humana, fundamento da República brasileira, salientando a impossibilidade de tratamento do indivíduo como objeto, destituído de vontade própria, como mero instrumento de realização de outras finalidades, sendo, pois, intrinsecamente vinculada a um poder de autodeterminação para desenvolver livremente a personalidade individual. ${ }^{157} \mathrm{O}$ indivíduo assume, dessa forma, posição central, devendo ser respeitado e reconhecido antes de qualquer valor ou interesse de terceiro ou da coletividade.

Considerando o modelo de Estado Constitucional de Direito atual, verifica-se que o princípio da autorresponsabilidade, norma que expressa mandamento de "dever-ser" atuando diretamente na relação Estado-indivíduo e, também, indivíduo-indivíduo ${ }^{158}$ - se irradia por todos os ramos do Direito, influenciando posturas político-sociais de todo o tipo, marcando inúmeras discussões ${ }^{159}$.

\footnotetext{
${ }^{157}$ Nesse sentido, LÓPEZ DÍAZ, Claudia. op. cit., p. 371. BECHARA, Ana Elisa Liberatore Silva. Da teoria do bem jurídico como critério de legitimidade do direito penal, cit., p 57-63, 179-180 e 187-194. Id. Direitos humanos e direito penal: limites da intervenção penal racional no Estado Democrático de Direito, cit. Também vinculando a autodeterminação do homem à noção de dignidade, a lição de Pierpaolo Cruz Bottini: "O Estado Democrático de Direito elege como valor fundante a dignidade humana. O reconhecimento da dignidade como coluna vertebral do sistema de relacionamentos humanos é o substrato material, é o núcleo de identidade normativa do modelo de Estado ora em discussão. A consolidação de uma sociedade plural e democrática, que incorpore e aceite valores e culturas diversos, exige o reconhecimento da autodeterminação do homem, que caracteriza a dignidade. O livre desenvolvimento do ser humano em um ambiente comunicativo e a possibilidade de optar pela construção do mundo de vida que melhor lhe convier são as diretrizes para a construção de todos os princípios norteadores do ornamento jurídico e, consequentemente, do direito penal." (Crimes de perigo abstrato. 2. ed. São Paulo: Ed. Revista dos Tribunais, 2010. p. 175-176). A respeito do conceito de dignidade humana e sua influência no Direito Penal, cf. COSTA, Helena Regina Lobo da. A dignidade humana: teoria da prevenção geral positiva. São Paulo: Ed. Revista dos Tribunais, 2008. O Supremo Tribunal Federal, em diversas oportunidades, já se utilizou da relação entre dignidade humana, pluralismo, e autonomia ou autodeterminação para fundamentar importantes decisões. Cf., p. ex., ADPF 132/RJ. Rel. Min. Ayres Britto. j.05//05/2011.e ADI 4277/DF. Rel.Min. Ayres Britto. j.05/05/2011. (acerca do reconhecimento da união homossexual), ADI 3510/DF. Rel.Min.Ayres Britto. j.29/05/2008. (acerca das pesquisas com células-tronco embrionárias).

158،El principio de autorresponsabilidad comporta, como punto de partida implicito del ordenamiento juridico, que toda persona ha de responder únicamente por su próprio actos, pues en tanto ser libre constitucionalmente protegido, tiene la facultad y el derecho de autodeterminarse sin injerencias externas: ni de las demás personas con quien convive en ela sociedad ni del Estado" (MEDINA FRISANCHO, José Luis. op. cit., p. 250-251).

${ }^{159}$ De um modo geral, pode-se dizer que a discussão se faz presente em diferentes áreas, ainda que, muitas vezes, com diversos fundamentos e valendo-se de terminologias diversas. Acerca da relação entre democracia e liberdade individual, em uma abordagem filosófico-política, cf. ROSENFIELD, D. L. Democracia e liberdade de escolha. Revista de Opinião Filosófica, v. 1, p. 1-39, 2010. No direito civil, cf. STANCIOLI, Brunello. Renúncia ao exercício dos direitos da personalidade ou como alguém pode se
} 
No âmbito da relação Estado-indivíduo, o princípio da autorresponsabilidade ligase diretamente às discussões que envolvem o chamado paternalismo estatal.

Pode-se dizer que o Estado é paternalista quando atua visando proteger o indivíduo ignorando a sua vontade, pouco importando se este deseja ou não tal proteção, muitas vezes afirmando um padrão de conduta baseado em uma suposta concepção de "vida boa"” ou de "vida moralmente recomendável". Agindo assim, o Estado assume a posição de pater, de educador, infantilizando os cidadãos, partindo do pressuposto de que o indivíduo não é capaz de fazer adequadamente as suas próprias escolhas, e que, portanto, caberia ao Estado fazê-las, ou, minimamente, orientá-las. Dessa forma, seria tarefa do Estado, de forma paternal, dizer o que é bom e o que é ruim para cada pessoa, aconselhando ou impondo determinados padrões de condutas, geralmente buscando legitimidade na opinião da maioria ${ }^{160}$, na denominada "opinião pública".

Habitualmente, o Estado utiliza diferentes instrumentos para exercer a sua postura paternalista, tais como campanhas informativas ${ }^{161}$, edição de normas regulamentares ${ }^{162} \mathrm{e}$ sanções administrativas ${ }^{163}$, política tributária ${ }^{164}$, leis cíveis ${ }^{165}$, e, finalmente, atuação de seu poder punitivo penal ${ }^{166}$.

tornar o que quiser. Belo Horizonte: Del Rey, 2010. No direito do consumidor, cf. BORGES, Luiz Guilherme de Melo. A relação jurídica de consumo sob o prisma do paternalismo jurídico. 2010. Dissertação (Mestrado) - Faculdade Milton Campos, Nova Lima, 2010. No direito médico, cf. BARROSO, Luís Roberto. Legitimidade da recusa de transfusão de sangue por testemunhas de Jeová: dignidade humana, liberdade religiosa e escolhas existenciais. Disponível em: $<$ http://www.luisrobertobarroso.com.br/wp-content/themes/LRB/pdf/testemunhas_de_jeova.pdf>. No campo da bioética e do biodireito, cf. MARTINS-COSTA, Judith; MOLLER, Letícia Ludwig (Orgs.). Bioética e responsabilidade. Rio de Janeiro: Forense, 2009.

${ }^{160}$ Stuart Mill já alertava para os perigos da chamada "tirania da maioria": "A vontade do povo significa, na prática, a vontade da parte mais numerosa o mais activa do povo: a maioria, ou aqueles que conseguem fazer-se aceitar como maioria; consequentemente, o povo pode desejar oprimir uma parte do povo; e são tão necessárias precauções contra isso como contra quaisquer outros abusos de poder. Por isso, a limitação do poder do governo sobre os indivíduos não perde qualquer importância quando os detentores do poder respondem regularmente perante a comunidade, ou seja, perante o partido mais forte da comunidade. Este modo de ver as coisas não tem encontrado dificuldade em afirmar-se, sendo apelativo tanto para a inteligência dos pensadores como para a inclinação daquelas classes importantes na sociedade europeia a cujos interesses a democracia é adversa; e nas reflexões políticas a 'tirania da maioria é agora geralmente incluída entre os males contra os quais a sociedade precisa se precaver." (MILL, John Stuart. Sobre a liberdade. Lisboa: Edições 70, 2006. p. 31-32).

${ }^{161} \mathrm{P}$. ex., campanhas que desmotivam o uso do cigarro de tabaco e de drogas em geral.

${ }^{162} \mathrm{P}$. ex, exigência de receita médica para compra de certos medicamentos e normas que proíbem banho de mar em área com correnteza ou tubarões.

${ }^{163} \mathrm{P}$. ex., obrigação de utilizar cinto de segurança em veículos e capacete em motos.

${ }^{164}$ P. ex., supertributação do tabaco.

${ }^{165} \mathrm{P}$. ex. norma que obriga o regime de separação total de bens no casamento após os 70 anos de idade.

${ }^{166}$ Cf. lista alternativa de exemplos em DWORKIN, Gerald. Paternalism. In: SARTORIUS, Rolf (Ed.). Paternalism. Minneapolis: University of Minnesota Press, 1983. p. 20-21. Segundo Maria Rigopoulou, 
Fala-se em paternalismo direto quando a atuação estatal visa impedir alguém de se autolesionar e em paternalismo indireto quando visa impedir comportamentos que provoquem lesão a outro, mesmo a pedido ou com o consentimento deste ${ }^{167}$. Em ambos os casos, a atuação é paternalista em relação ao indivíduo que deseja ou consente em se lesionar, ainda que a norma de proibição e a sanção possa recair sobre terceiro ${ }^{168}$.

É possível afirmar que a atuação paternalista tende a afrontar os preceitos do Estado Liberal. Nesse contexto, combatendo o Estado paternalista, de forma geral, merece destaque o trabalho de John Stuart Milll, elaborado na Inglaterra do séc. XIX, no qual se discute, com profundidade, a natureza e os limites do poder que pode ser exercido pelo Estado e pela sociedade sobre o indivíduo. Costuma-se a apontar este autor britânico como um dos primeiros a desenvolver as raízes de um chamado harm principle (princípio do dano), segundo o qual o Estado só estaria legitimado a intervir contra a vontade do indivíduo em caso de prevenção de dano a outros ${ }^{169}$.

\footnotetext{
“enquanto intervenções paternalistas como campanhas informativas e incentivos fiscais não apresentam problema algum, uma vez que a decisão final do comportamento continua sendo do indivíduo, as proibições com caráter coercitivo não são facilmente justificáveis, já que elas orientam diretamente a vontade do indivíduo". (Traços paternalistas no direito penal da atualidade. Revista Brasileira de Filosofia, São Paulo, n. 227, p. 348, 2007).

${ }^{167}$ É claro que, muitas vezes, a definição do que é considerado uma "lesão" ou um "dano" fica a cargo do Estado, que se coloca na posição de dizer o que é bom e o que é ruim e, portanto, o que é supostamente lesivo e o que não é lesivo ao indivíduo, frequentemente apenas estabelecendo padrões de condutas moralmente dominantes, diferenciando o "certo" do "errado". Nos crimes relacionados à prostituição, por exemplo, quem é que diz que o ato de se prostituir é lesivo a alguém? Sobre o tema, tentando estabelecer um significado para "dano" (harm), cf. FEINBERG, Joel. Harm to others: the moral limits of criminal law. New York: Oxford University Press, 1984. v. 1, p. 31-36. Id. Harm to self: the moral limits of criminal law. New York: Oxford University Press, 1986. v. 3, p. 8-10. Tal questão poderá acarretar problemas conceituais e terminológicos e, por razões metodológicas, será abordada apenas topicamente ao longo deste trabalho.

${ }^{168}$ FEINBERG, Joel. Harm to self: the moral limits of criminal law, cit., v. 3, p. 9-10. Gerald Dworkin chama de paternalismo puro ou impuro (Paternalism, cit., p. 22).

169“'O objectivo deste ensaio é asseverar um princípio muito simples, que se destina a reger em absoluto a interação da sociedade com o indivíduo no que diz respeito à coação e controlo, quer os meios usados sejam a força física, na forma de punições legais, quer a coerção moral da opinião pública. É o princípio de que o único fim para o qual as pessoas têm justificação, individual ou colectivamente, para interferir na liberdade de acção de outro, é a autoprotecção. É o princípio de que o único fim em função do qual o poder pode ser correctamente exercido sobre qualquer membro de uma comunidade civilizada, contra a sua vontade, é o de prevenir dano a outros. O seu próprio bem, que físico, quer moral, não é justificação suficiente. Uma pessoa não pode ser correctamente forçada a fazer ou a deixar de fazer algo porque será melhor para ela que o faça, porque a fará feliz, ou porque, na opinião de outros, fazê-lo seria sensato ou até correcto. Estas são boas razões para criticar, para debater com ela, para persuadir, ou para exortar mas não para forçar, ou para lhe causar algum mal caso ela haja de outro modo. (...). A única parte da conduta de qualquer pessoa pela qual ela responde perante a sociedade, é a que diz respeito aos outros. Na parte de sua conduta que apenas diz respeito a si, a sua independência é, por direito, absoluta. Sobre si, sobre o seu próprio corpo e a sua própria mente, o indivíduo é soberano." (MILL, John Stuart. op. cit., p. 39-40).
} 
Este princípio foi retomado, já na década de 80 do séc.XX, nos Estados Unidos, especialmente tratando do Direito Penal, por autores como Joel Feinberg ${ }^{170}$ e Gerald Dworkin ${ }^{171}$. Tais autores, inseridos no modelo anglo-saxão, construíram, cada um a sua maneira, doutrinas liberais denominadas de antipaternalistas ${ }^{172}$, reascendendo, de certa forma, as discussões acerca do tema no cenário internacional, com alguma repercussão no Brasil ${ }^{173}$.

O presente trabalho, todavia, sem ignorar as contribuições da chamada doutrina antipaternalista e os diversos pontos de contato, busca, diversamente, fixar-se em premissas normativas típicas do modelo jurídico romano-germânico, por entender ser este o caminho mais adequado ao sistema jurídico brasileiro, ao modelo de Estado Constitucional e Democrático de Direito, apto, portanto, a produzir relevantes consequências práticas ${ }^{174}$.

Tendo isto em consideração, o que se observa é que a atuação paternalista do Estado - mormente pelo uso da coerção ${ }^{175}$ - parece apontar para uma violação frontal ao

${ }^{170}$ FEINBERG, Joel. op. cit., v. 1 e 3.

${ }^{171}$ DWORKIN, Gerald. op. cit.

${ }^{172}$ MARTINELLI, João Paulo Orsini. Paternalismo jurídico-penal. 2010. Tese (Doutorado) - Faculdade de Direito, Universidade de São Paulo, São Paulo, 2010. p. 122-162.

${ }^{173}$ Cf. coletânea de artigos da Revista Brasileira de Filosofia no 227 , São Paulo, 2007. MARTINELLI, João Paulo Orsini. op. cit.

${ }^{174}$ Em sentido semelhante, Ana Elisa Liberatore Silva Bechara recusa a utilização do harm principle no Direito Penal brasileiro, criticando a importação acrítica de institutos do sistema anglo-saxão. (Da teoria do bem jurídico como critério de legitimidade do direito penal, cit., p. 286-292). Em sentido contrário, defendendo a integração dos sistemas e a utilização do harm principle também no sistema romanogermânico, em trabalho que tem como principal referência as chamadas doutrinas antipaternalistas, MARTINELLI, João Paulo Orsini. op. cit., p. 18-20. Mencionando uma chamada "globalizacíon de la discusíon sobre los fundamentos penales", Claus Roxin aponta a existência pontos de contato entre o conceito de bem jurídico, típico do modelo europeo-continental, e o harm principle, fundamentado, no modelo angloamericano, por Stuart Mill, e desenvolvido pelo Feinberg, cf. ROXIN, Claus. El legislador no lo puede todo. Iter Criminis: revista de ciencias penales, México, n. 12, p. 325-326, out./mar. 2004/2005.

${ }^{175}$ Buscando diferenciar as ações de tutelar e informar por parte do Estado, a lição de Denis Lerrer Rosenfield: "A questão torna-se ainda mais complexa - e pode-ser-ia dizer mais perigosa - pelo fato dessa imposição de regras dizer respeito à vida cotidiana das pessoas, destituindo-as, na verdade, da sua capacidade de decidir por si mesmas, A tutela estatal é, sem dúvida, uma coerção, um cerceamento de liberdade. O Estado, assim, se coloca como um espécie de instância moral que teria a função de formular normas que ditariam o que o cidadão deve ou não fazer. A ação dos indivíduos estaria, então, submetida a um dever ser político que controlaria totalmente as pessoas. Tais medidas seriam implementadas a partir da noção aparente de que o bem dos cidadãos estaria sendo realizado, quando, de fato, o bem maior, a liberdade de escolha, estaria saindo progressivamente de cena. A tutela entra por uma porta, a liberdade sair pela outra. (...). Há uma grande confusão entre o Estado informar e tutelar. Cabe ao Estado, por exemplo, informar amplamente a população acerca dos malefícios - eventuais ou comprovados - do consumo de determinados produtos na vida das pessoas. Diria mesmo que é sua função mostrar aos cidadãos como certos objetos de sua eleição podem vir a afetá-los. Nesse sentido, é obrigação do ente estatal informar, até por meio de amplas campanhas publicitárias, a respeito dos efeitos para a saúde do consumo excessivo de alguns produtos. Poderiam entrar nesse rol o álcool, as gorduras saturadas, o fumo, o açúcar e o sódio, entre outros objetos de consumo e/ou prazer. Agora, se o cidadão informado quiser, no exercício de sua liberdade de escolha, continuar a consumir tais itens, trata-se de uma opção exclusivamente pessoal, pela qual ele é inteiramente responsável, mesmo ao custo de sua saúde. O Estado informa, o cidadão escolhe." (ROSENFIELD, D. L. Informar e tutelar. O Estado de S. Paulo, São Paulo, 08 out. 2012. p. A2). 
princípio da autorresponsabilidade, acenando, pois, para uma potencial situação de incompatibilidade com a Constituição. Somente um ordenamento jurídico que garanta à pessoa a faculdade de desenvolver-se livre e autonomamente pode ser tido como um regime verdadeiramente democrático ${ }^{176}$.

Este trabalho, por razões metodológicas e por rigor científico, se limitará a analisar o impacto da aplicação do princípio da autorresponsabilidade no Direito Penal, o que será feito a seguir ${ }^{177}$. Pelo mesmo motivo, visando delimitar o tema, não serão abordadas as situações que envolvem pessoas legalmente consideradas como de capacidade de discernimento reduzida ou inexistente, a exemplo dos menores de 18 anos de idade e dos deficientes mentais ${ }^{178}$.

\subsection{Impacto no Direito Penal}

Como visto, a adoção de um modelo de Estado Constitucional e Democrático de Direito traz como consequência a formatação de um Direito Penal ConstitucionalDemocrático, ou seja, de um Direito Penal presidido normativamente pela Constituição e pautado pelos valores do Estado Democrático de Direito. Nesse cenário, a Constituição figura principalmente como limitadora do poder punitivo estatal, garantidora da liberdade individual, construindo, portanto, um modelo de intervenção penal mínima.

\footnotetext{
${ }^{176}$ LÓPEZ DÍAZ, Claudia. op. cit., p. 361.

${ }^{177}$ As implicações do princípio da autorresponsabilidade nos demais ramos do Direito não integram o objeto deste trabalho. Admite-se, porém, preliminarmente, que cada regime jurídico possa conduzir a conclusões diversas acerca da legitimidade da intervenção estatal. Elevar o consumo de tabaco à condição de crime, por exemplo, parece ser bastante diverso do que elevar o tributo incidente sobre a circulação deste produto. Deixa-se o regime Constitucional-Penal e adentra-se no regime Constitucional-Tributário. Para uma visão geral da diferença - quantitativa e qualitativa - entre criminalização e supertributação do consumo de tabaco, com a finalidade paternalista, cf. FEINBERG, Joel. Harm to others: the moral limits of criminal law, cit., v. 1, p. 23-25.

${ }^{178}$ De modo semelhante, assevera John Stuart Mill: “Talvez nem seja preciso dizer que se parte do princípio de que esta doutrina se aplica apenas a seres humanos na maturidade das suas faculdades. Não estamos a falar de crianças, ou de jovens abaixo da idade que a lei possa estabelecer como a da maioriadade para homens e para mulheres. Aqueles que se encontram ainda num estado em que precisem que os outros cuidem de si, têm de ser protegidos contra as suas próprias acções bem como contra danos externos" (Sobre a liberdade, cit., p. 40). As doutrinas antipaternalistas costumam a diferenciar o paternalismo rígido ou duro (hard paternalism) - que se propõe a prevenir danos à pessoa mesmo contrariando sua vontade plenamente responsável - do moderado ou brando (soft paternalism) - que se propõe a prevenir danos somente àquelas pessoas com capacidade de discernimento reduzida ou inexistente, ou quando existam dúvidas sobre a voluntariedade e capacidade de autonomia, ainda que temporariamente. Cf. FEINBERG, Joel. Harm to self: the moral limits of criminal law, cit., v. 3, p. 12-16. Para essa e outras classificações, cf. MARTINELLI, João Paulo Orsini. op. cit., p. 115-120. FEINBERG, Joel. Harm to self: the moral limits of criminal law, cit., v. 3, p. 8-10.
} 
Tal modelo, adotado pela Constituição brasileira, é expresso normativamente pelo princípio da intervenção penal mínima, o qual determina que a intervenção do poder punitivo estatal só se legitima como última alternativa, depois de esgotadas todas as possibilidades de atuação por outros meios - caráter subsidiário -, e, ainda, somente quando envolva ataques a bens jurídicos fundamentais - caráter fragmentário. Seria certamente ilógico admitir a forma de intervenção mais grave do Estado na vida do indivíduo quando outro modo de intervenção se mostre adequado ${ }^{179}$.

Parte-se, assim, da constatação de que a intervenção penal não é somente quantitativa, mas, também, qualitativamente diversa das demais formas intervenção estatal, sendo que, por ser a mais gravosa delas, submete-se a um sistema de limitação especialmente mais rigoroso.

Tal conformação do Direito Penal dentro do modelo de Estado Democrático de Direito conduz a uma conclusão lógica: se há fundadas dúvidas acerca da legitimidade de intervenção do Estado valendo-se de outros instrumentos ou por meio de outros ramos do Direito, há certeza no sentido da ilegitimidade de intervenção por meio do poder punitivo penal. No atual modelo de Estado, o que legitima a intervenção penal é unicamente a ocorrência direta de dano ou perigo de dano a bem jurídico alheio ${ }^{180}$.

O princípio da autorresponsabilidade exerce - ou pelo menos deveria exercer um importante papel dentro deste sistema de limitação da intervenção penal. Trata-se de princípio constitucional de aplicação geral, não exclusivamente penal, e que, no que tange ao poder punitivo, surge como fundamental instrumento de contenção, verdadeiro vetor na construção de um Direito Penal Constitucional-Democrático, especialmente no que tange a atuação paternalista do poder punitivo estatal ${ }^{181}$.

Desde já, importa consignar que condutas que representem tão-somente a manifestação do livre exercício da personalidade, da autodeterminação, sem qualquer

\footnotetext{
179“'O delito, no fundo, só deve ser visto como tal quando implique violação do direito de liberdade de outra pessoa, e cuja manutenção não possa ser obtida por meios menos gravosos" (TAVARES, Juarez. Prefácio. In: PASCHOAL, Janaina Conceição. Constituição, criminalização e direito penal mínimo, cit., p. 13).

${ }^{180}$ Tal conclusão pode ser extraída, também, do próprio princípio da lesividade, o qual exige a exterioridade e a alteridade como características da conduta objeto de incriminação. Cf. BATISTA, Nilo. Introdução crítica ao direito penal brasileiro, cit., p. 91-97.

181،A consciente autolesão (...), como também sua possibilitação e fomento, não legitimam uma sanção punitiva, pois a proteção de bens jurídicos tem por objeto a proteção frente à outra pessoa, e não frente a si mesmo. Um paternalismo estatal, enquanto este deva ser praticado através do Direito Penal, é por isto justificável somente tratando-se de déficits de autonomia do afetado (menores de idade, perturbados mentais que não compreendem corretamente o risco para si)" (ROXIN, Claus. A proteção de bens jurídicos como função do direito penal, cit., p. 23).
} 
dano direto a terceiro, não podem ser objeto de intervenção do poder punitivo estatal, seja direta ou indiretamente, sob pena de violação ao princípio da autorresponsabilidade. Seria, certamente, um paradoxo admitir uma intervenção penal - que tem como base de legitimidade, como demonstrado, a afirmação da liberdade e do livre desenvolvimento do indivíduo - justamente sobre condutas que concretizam o exercício desses direitos fundamentais ${ }^{182}$. A simples expressão de um direito fundamental jamais pode ser objeto de intervenção do poder punitivo estatal ${ }^{183}$.

No Estado Democrático de Direito, tolerante, laico, e pluralista por excelência ${ }^{184}$, consagrado na Constituição brasileira de 1988, o princípio da autorresponsabilidade assegura que regras da moral ou da religião, concepções de "vida boa", padrões supostamente dominantes pautados pelos chamados "bons costumes", sentimentos de repugnância, de escândalo ou de desconforto, ainda que compartilhados pela maioria ou pela unanimidade dos membros da sociedade, não têm o condão de legitimar a intervenção penal estatal ${ }^{185}$.

Neste ponto, cabe ressaltar, ainda, que, no modelo democrático, danos apenas remotos ou indiretos a terceiro não servem de parâmetro para legitimar a intervenção penal. Por certo, todo ou quase todo comportamento humano acaba por afetar, de alguma forma, algum terceiro, próximo ou não ${ }^{186}$. Assim, por exemplo, o suicídio de um

\footnotetext{
182،"Muitas pessoas expõem-se a perigo: através de maus hábitos alimentares, do fumo, do álcool ou de outras atividades arriscadas, como a condução de automóveis velozes ou a prática de esportes perigosos. Esses comportamentos e a sua promoção por terceiros não constituem um objeto legítimo do direito penal, pois a finalidade deste é unicamente impedir que alguém seja lesionado contra a sua vontade. O que ocorre de acordo coma a vontade do lesionado é uma componente de sua auto-realização, que em nada interessa ao Estado." (ROXIN, Claus. Estudos de direito penal. 2. ed. Rio de Janeiro: Renovar, 2008. p. 44).

183، O poder discricionário do legislador ordinário na escolha de bens a tutelar com a pena encontra um limite instransponível: não podem ser reprimidos comportamentos que sejam a expressão de princípios ou de direitos de liberdades garantidos pela Constituição." (MARINUCCI, Giorgio; DOLCINI, Emilio. Constituição e escolhas de bens jurídicos, cit., p. 164).

${ }^{184}$ Sobre a importância do modelo de tolerância, secularização, e pluralismo no Direito Penal, sobretudo como limites ao poder de criminalização, cf. PALAZZO, Francesco. Valores constitucionais e direito penal, cit., p. 84-92.

${ }^{185}$ Janaína Conceição Paschoal lembra que "sob o pretexto de tutelar, o Estado deixa muito pouco espaço para o indivíduo efetivamente exercer seu direito a ser diferente". (Ingerência indevida: os crimes comissivos por omissão e o controle da punição do não fazer, cit., p. 17). Bern Shunemann, por sua vez, vinculando o princípio da proteção de bens jurídicos à garantia da possibilidade do livre desenvolvimento dos indivíduos pelo Estado, assevera que "em todas as sociedades totalitárias, o que se tentava era impor coativamente determinadas formas de vida, sendo que, se o conteúdo destas formas de vida foi a cada vez diverso, o princípio da submissão do povo sob o ditado de uma pequena camada dominante permaneceu sempre o mesmo." (O direito penal é a ultima ratio da proteção de bens jurídicos: sobre os limites invioláveis do direito penal em um estado de direito liberal. Revista Brasileira de Ciências Criminais, São Paulo, v. 13, n. 53, p. 12, mar./abr. 2005).

${ }^{186}$ Fala-se em um princípio do "no-man-is-an-island”. Cf. MARTINELLI, João Paulo Orsini. op. cit., p. 43.
} 
indivíduo poderá acarretar terríveis sentimentos em parentes e amigos próximos, prejuízos econômicos àqueles que dependiam de sua renda, além de representar uma perda de mão de obra útil à sociedade. Nada disso, porém, poderá suplantar o direito de autodeterminação do indivíduo, a ponto de afastar o ilegítimo caráter paternalista da intervenção penal ${ }^{187}$.

Dessa forma, considerando o modelo de vinculação normativa propugnado pelo Estado Constitucional de Direito, pode-se dizer que o princípio da autorresponsabilidade atua como parâmetro negativo de legitimidade da atuação do poder punitivo estatal.

Assim sendo, verifica-se que primeiro grande impacto da aplicação do princípio da autorresponsabilidade relaciona-se aos tipos penais paternalistas, seja quando expressam um paternalismo direto seja quando revelam um paternalismo indireto. Não há dúvidas de que o paternalismo estatal penal é a forma mais aguda e forte de paternalismo jurídico $^{188}$.

No que toca à atuação paternalista indireta, verifica-se que o princípio da autorresponsabilidade exerce, já no âmbito da dogmática penal, importante influência sobre a chamada teoria do consentimento, a qual não pode mais se prender ao dogma da indisponibilidade de certos bens jurídicos individuais, elevado a uma condição de verdadeiro tabu, ignorando os preceitos do Estado Democrático de Direito.

\footnotetext{
${ }^{187}$ Nesse sentido, cf.: MILL, John Stuart. op. cit., p. 140 e seg. HIRSCH, Andrew von. Paternalismo direto: autolesões devem ser punidas penalmente? Revista Brasileira de Ciências Criminais, São Paulo, v. 15, n. 67, p. 24-25, jul./ago. 2007. RIGOPOULOU, Maria. op. cit., p. 356. BECHARA, Ana Elisa Liberatore Silva. Da teoria do bem jurídico como critério de legitimidade do direito penal, cit., p. 192-193. MARTINELLI, João Paulo Orsini. op. cit., p. 42-43. Partindo do critério de autonomia dos cidadãos, combatendo também o argumento dos danos indiretos, importante a lição de Luís Greco, criticando decisão do Tribunal Constitucional alemão que afirmou a legitimidade do crime de incesto: "Principalmente no que diz respeito a questões referentes à chamada 'boa vida', qualquer intervenção estatal significará um desrespeito a essa autonomia, entendida aqui grosseiramente como o direito de viver segundo seu próprio plano de vida e sua própria ideia de uma 'boa vida'. O homossexualismo não é um delito, porque é um direito do homossexual ser como ele é. O mesmo se diga do incesto. Ainda que o reproche social dessa prática seja ainda mais decidido que o dirigido ao homossexualismo, pessoas adultas têm o direito de praticar relações sexuais com pessoas adultas, de próximo parentesco ou não. Pela mesma razão é, sim, de reconhecer-se - contra o Tribunal Constitucional - um direito de se drogar. Ainda que majoritariamente não admiremos o 'maconheiro', ainda que ele onere nosso sistema de saúde - isso não autoriza a utilização do direito penal contra a posse de tóxicos, mas no máximo uma certa recusa a medidas assistenciais. Só o argumento da autonomia pode superar o apelo do moralista a consequências indiretas decorrentes do exercício de um direito, afirmando que elas justamente não vêm ao caso." (GRECO, Luís. Tem futuro a teoria do bem jurídico? Reflexões a partir da decisão do Tribunal Constitucional Alemão a respeito do crime de incesto (§ 173 Strafgesetzbuch). Revista Brasileira de Ciências Criminais, São Paulo, v. 18, n. 82, p. 165-185, jan./fev. 2010).

${ }^{188}$ RIGOPOULOU, Maria. op. cit., p. 354.
} 
Por fim, ainda no âmbito da dogmática penal, o princípio da autorresponsabilidade impacta a chamada teoria da imputação do resultado, de modo a também impedir a atuação paternalista estatal, servindo de critério negativo para o preenchimento da tipicidade objetiva.

Os tópicos acima elencados serão estudados, separada e detalhadamente, nos capítulos seguintes. 


\section{PRINCÍPIO DA AUTORRESPONSABILIDADE E TIPOS PENAIS PATERNALISTAS}

A história do poder punitivo tem como uma de suas marcas a frequente atuação paternalista estatal, manifestada, dentre outras formas, por meio do estabelecimento de tipos penais paternalistas. O Estado, na ânsia de expandir seu poder de controle sobre os cidadãos, de estabelecer padrões de conduta ou um "modo de ser" dominantes, buscando atender a padrões morais e religiosos majoritários, acaba por expandir seu poder de punir a condutas que não lesionam qualquer bem jurídico ou que, no máximo, lesionam apenas o bem jurídico do próprio indivíduo sobre qual o Estado pretende fazer incidir seu poder, criando, assim, verdadeiras infrações penais sem vítimas.

No Brasil, a história do Direito Penal é repleta de exemplos desse tipo de repressão a condutas apenas "socialmente inconvenientes". Desde as Ordenações Portuguesas, passando pelos Códigos Penais de 1830 e 1890, e chegando ao Código Penal de 1940 e à Lei de Contravenções Penais de $1941^{189}$, ambos ainda em vigor, é possível verificar a presença de uma série de tipos paternalistas ${ }^{190}$.

Ocorre que, com a superveniência da Constituição Federal de 1988, consagradora de um modelo de Estado Constitucional e Democrático de Direito, o Direito Penal passou a ter como referência de legitimidade uma Constituição democrática. Logo, neste novo cenário, os tipos penais - muitos dos quais criados no período autoritário da década de 1940 - devem, necessariamente, encontrar-se em consonância com o rígido sistema de limitação do poder punitivo formatado pelo texto constitucional, no âmbito de um Direito Penal Constitucional-Democrático, sob pena de não recepção ou de inconstitucionalidade.

O princípio da autorresponsabilidade, como visto, integra esse sistema de limitação do poder punitivo, devendo, pois, servir de parâmetro para a aferição da constitucionalidade dos tipos penais. Nunca é demais lembrar que, no atual modelo de Estado, o princípio da autorresponsabilidade, como norma constitucional, deve atuar sobre todos os agentes do poder punitivo, notadamente sobre o legislador penal, orientando o processo de criminalização e

\footnotetext{
${ }^{189}$ Cf. PIERANGELI, José Henrique. Códigos penais do Brasil: evolução histórica. 2. ed. São Paulo: Ed. Revista dos Tribunais, 2001.

${ }^{190}$ Para uma análise histórica do paternalismo penal no Brasil, com destaque para o período inicial da República, cf. REALE JÚNIOR, Miguel. Paternalismo no Brasil. Revista Brasileira de Filosofia, São Paulo, n. 227, p. 287-319, 2007.
} 
descriminalização, e sobre o juiz penal, que somente deverá aplicar e reconhecer como legítimos tipos penais que se encontrem em consonância com a Constituição.

Em seguida, será feita uma análise dos principais tipos penais paternalistas em vigor no cenário jurídico brasileiro, considerando, sobretudo, o princípio constitucional ora em estudo.

\subsection{Vadiagem e embriaguez}

A expansão do poder punitivo estatal até as condutas de vadiagem e embriaguez é algo que sempre esteve presente na história do Direito Penal brasileiro. O Código Penal de 1830 trazia, em seus artigos 295 e 296, a figura dos "Vadios e mendigos" e, no art.280, a criminalização de qualquer conduta que, de acordo com a opinião pública, era considerada ofensiva à moral e aos bons costumes, praticada em lugar público. O Código Penal de 1890, por sua vez, estabelecia as figuras "Dos mendigos e ebrios" (art.391 a 398) e "Dos vadios e capoeiras" (art.399 a 402) ${ }^{191}$.

O Código Penal de 1940 não se ocupou de tais condutas, deixando a tarefa para a Lei de Contravenções Penais de 1941, a qual, em seu Capítulo VII ("Das contravenções relativas à polícia de costumes”), manteve as infrações penais de vadiagem (art.59) ${ }^{192}$, de embriaguez (art.62) ${ }^{193}$ e de mendicância (art.60) ${ }^{194}$. Apenas esta última foi revogada, com muito atraso, pela Lei $\mathrm{n}^{\circ} 11.983$ de 2009.

Como indica o próprio nome do capítulo, eleva-se à condição de bem jurídico uma tal "polícia de costumes", ou seja, os "bons costumes" dominantes na sociedade ${ }^{195}$. Todavia, no modelo de Estado Democrático de Direito, pluralista por excelência, o

\footnotetext{
${ }^{191}$ Cf. PIERANGELI, José Henrique. op. cit. Miguel Reale Júnior destaca que, embora não tenha havido uma efetiva repressão a estas condutas no período imperial, nos primeiros anos da República, uma conjugação de fatores - ideológicos sociológicos e políticos - contribuíram para uma elevada repressão penal à vadiagem, à mendicância, à embriaguez e à capoeiragem. (Paternalismo no Brasil, cit., p. 305).

192، Art. 59. Entregar-se alguém habitualmente à ociosidade, sendo válido para o trabalho, sem ter renda que lhe assegure meios bastantes de subsistência, ou prover à própria subsistência mediante ocupação ilícita”.

193، Art. 62. Apresentar-se publicamente em estado de embriaguez, de modo que cause escândalo ou ponha em perigo a segurança própria ou alheia".

194“"Art. 60. Mendigar, por ociosidade ou cupidez."

${ }^{195}$ Acerca de tais expressões, cf. SILVEIRA, Renato de Mello Jorge. Lei das Contravenções Penais - parte especial - capítulo VII: das contravenções referentes à política de costumes - arts. 59 a 65. In: SALVADOR NETTO, Alamiro Velludo (Coord.). Comentários à Lei das Contravenções Penais. São Paulo: Quartier Latin, 2006. p. 271-296.
} 
princípio da autorresponsabilidade assegura que cada indivíduo é livre para escolher a forma de vida que desejar, o que significa liberdade para escolher a que costumes ou a que moral quer se filiar, ainda que minoritários, ou, até mesmo, para criar seus próprios costumes pessoais ou a sua própria moral individual. Basta isso para concluir que "polícia de costumes" ou "bons costumes" não são bens jurídico-penais legítimos no atual modelo do Estado ${ }^{196}$.

No que tange à vadiagem, segundo a redação legal, pune-se com pena de prisão aquele que se entregar habitualmente à ociosidade, sendo válido para o trabalho, sem ter renda que lhe assegure meios bastantes de subsistência, ou prover à própria subsistência mediante ocupação ilícita. O alvo do poder punitivo estatal é, portanto, o indivíduo que opta por não trabalhar, sem que tenha outros meios que lhe garantam a subsistência. A toda evidência, vale-se de um discurso paternalista, argumentando-se que a entrega à ociosidade seria ruim para o indivíduo ${ }^{197}$.

Trata-se, por certo, de repressão penal que recai tão-somente sobre uma forma de vida, sobre um determinado modo de $\operatorname{ser}^{198}$, sobre uma opção pela vida não vinculada ao trabalho, sem que isto cause dano ou perigo de dano a quem quer que seja. Recrimina-se unicamente uma conduta entendida como antissocial por violar costumes supostamente ideais ${ }^{199}$. Na realidade, por trás do discurso oficial, resta escancarada a faceta mais perversa do Direito Penal, a saber, a tentativa de criminalização da pobreza, servindo de pretexto para recolher das ruas e levar à Delegacia de Polícia indivíduos - moradores de rua, pedintes, mendigos, etc - que simplesmente "incomodam" as classes economicamente dominantes. Evidencia-se a criminalização do indivíduo socialmente inconveniente, chegando-se ao ponto de se pretender presumir a periculosidade destes vadios (art.14, II, da LCP) ${ }^{200}$, imaginando-se que oferecem risco à população.

\footnotetext{
${ }^{196}$ Em sentido semelhante, SILVEIRA, Renato de Mello Jorge. op. cit., p. 276-278. Sobre o tema, Stuart Mill já alertava que "também é necessária protecção contra a tirania da opinião e do sentimento dominantes; contra a tendência da sociedade para impor, por outros meios que não as punições civis as suas próprias ideias e práticas como regras de condutas àqueles que não as seguem, e para restringir o desenvolvimento - e, se possível, impedir a formação - de qualquer individualidade que não esteja em harmonia com os seus costumes, e para forçar todas as personalidades a modelarem-se à imagem da sociedade." (Sobre a liberdade, cit., p. 32).

${ }^{197}$ ESTELLITA, Heloisa. Paternalismo, moralismo e direito penal: alguns crimes suspeitos em nosso direito positivo. Revista Brasileira de Filosofia, São Paulo, v. 56, n. 227, p. 333-341, 2007.

${ }^{198}$ REALE JÚNIOR, Miguel. Paternalismo no Brasil, cit., p. 311.

${ }^{199}$ SILVEIRA, Renato de Mello Jorge. op. cit., p. 277.

${ }^{200}$ Art. 14. Presumem-se perigosos, além dos indivíduos a que se referem os ns. I e II do art. 78 do Código Penal: (...) II - o condenado por vadiagem ou mendicância.
} 
Não é preciso muito esforço para se concluir que o tipo do art.59 da Lei de Contravenções Penais viola o princípio da autorresponsabilidade e, portanto, não fora recepcionado pela ordem constitucional inaugurada em $1988 .{ }^{201}$ O princípio da autorresponsabilidade assegura a liberdade de todas as formas de vida, incluindo, logicamente, a opção por viver na ociosidade. A opção por ser "vadio" e "ocioso" integra a livre manifestação de personalidade de qualquer pessoa, embora possa ser, eventualmente, considerado "ruim" ou "moralmente reprovável" por determinados grupos de indivíduos, ainda que majoritários.

Vale lembrar, nesse sentido, que o que a Constituição de 1988 garante é o direito fundamental ao trabalho $\left(\operatorname{art} .6^{\circ}\right)$ e ao livre exercício de qualquer trabalho $\left(\operatorname{art} .5^{\circ}\right.$ XIII), o que jamais pode ser convertido, por vontade do legislador penal, em um inexistente dever jurídico de trabalhar.

Embora se afirme que a repressão penal à vadiagem tenha caído em desuso, não é tão raro ver ainda hoje - em pleno século XXI, passados aproximadamente 25 anos desde a promulgação da atual Constituição - a Polícia Militar recolhendo às Delegacias dezenas de indivíduos pobres ou miseráveis, os quais apenas vagam pelas ruas, lavrando-se Termo Circunstanciado de Ocorrência (TCO) pela contravenção de vadiagem ${ }^{202}$. Não é necessário dizer que absolutamente todos os atos de persecução penal, desde a apreensão pelos Policiais, passando pela condução à Delegacia e pela lavratura do TCO, chegandose à privação da liberdade, ainda que momentânea, carecem de legitimidade no modelo de Estado adotado pelo Brasil atualmente.

\footnotetext{
201،A ideia autoritária de um Estado interventor ou, mesmo, de simples presunção quanto à periculosidade de não trabalhadores é de todo reprovável. Incabível, em um Estado Democrático de Direito, a concepção de um controle policial de pessoas que não se encontrem em trabalho, por mera questão preventiva." (SILVEIRA, Renato de Mello Jorge. op. cit., p. 278).

${ }^{202}$ Recentemente, p. ex., o jornal $O$ Estado de $S$. Paulo (ed. de 02 jun. 2012. p. C4) noticiou que um juiz do Colégio Recursal da cidade de Franca-SP indeferiu liminar em habeas corpus impetrado pela Defensoria Pública em favor de mais de 50 pessoas que - por recomendação do juiz da Vara de Execução Criminais de Franca - foram detidas e conduzidas à Delegacia para a lavratura de TCO pela contravenção de vadiagem. Vale transcrever trecho de outra reportagem sobre os mesmos fatos ocorridos no interior paulista: "Na cidade as opiniões se dividem, mas principalmente os comerciantes defendem a detenção dos moradores de rua, pois dizem que prejudicam o movimento e incomodam os clientes. O secretário de Ação Social de Franca, Roberto Nunes Rocha, defende a abordagem aos moradores de rua. Segundo ele, muitos chegam a ganhar R\$ 100 por dia atuando como pedintes. E que mesmo a prefeitura colocando à disposição o abrigo provisório com toda estrutura de atendimento, eles preferem ficar pedindo porque é mais rentável". (MOREIRA, Rene. Justiça nega habeas corpus em favor de morador de rua. Disponível em: $<$ http://veja.abril.com.br/noticia/brasil/justica-nega-habeas-corpus-em-favor-de-morador-de-rua $>$. Acesso em: 07 jun. 2012). Posteriormente, em julgamento realizado no dia 15/08/2012, o Tribunal de Justiça de São Paulo concedeu a ordem de habeas corpus, impetrado contra o indeferimento da liminar pelo juiz do Colégio Recursal, "para garantir aos pacientes o direito de ir, vir e permanecer em logradouros públicos, a qualquer hora do dia, não podendo ser removidos contra sua vontade, salvo por ordem judicial ou em caso de flagrante delito." (Cf. TJSP - HC nº 0115880-26.2012.8.26.0000. Rel.Des.Paulo Rossi. j.15/08/2012).
} 
Com relação à contravenção de embriaguez, verifica-se, pela redação legal, a expansão do poder punitivo àqueles que se apresentam publicamente em estado de embriaguez, de modo que cause escândalo ou ponha em perigo a segurança própria ou alheia. Insere-se no mesmo contexto da vadiagem, caracterizando-se, notadamente, por ser mais uma tentativa de repressão àqueles que vagam pelas ruas embriagados, geralmente pertencente à classe social menos favorecida economicamente ${ }^{203}$.

Primeiramente, é preciso dizer que o ato de se embriagar - seja em público, seja no âmbito privado -, por si só, representa, no máximo, um comportamento autolesivo, que somente diz respeito ao próprio indivíduo. Embriagar-se com habitualidade, como se refere o parágrafo único do art.62 da LCP, revela apenas a escolha livre de uma forma de vida, no pleno exercício da autorresponsabilidade.

O objetivo, aqui, mais uma vez, parece ser recriminar um comportamento apenas socialmente inconveniente, supostamente contrário à moral e aos "bons costumes" dominantes. Isso se mostra evidente na primeira figura do tipo, que pune a embriaguez pública "que cause escândalo". Trata-se, como se vê, da criminalização de ato que não provoca dano a nenhum bem jurídico-penal, proibindo-se o comportamento considerado tão somente "anormal" ou "escandaloso", o que é incompatível com o modelo de Estado Democrático de Direito adotado pela Constituição de 1988, defensor da tolerância diante das diferenças de todo o tipo.

A segunda figura, ao elevar à condição de infração penal a embriaguez pública que ponha em perigo a "segurança própria", revela um claro exemplo de paternalismo direto, buscando-se proteger o indivíduo dele mesmo, de suas próprias escolhas, em flagrante criminalização de conduta autolesiva. E, como já assentado, a criminalização da autolesão, ainda que cause escândalo ou outros danos indiretos aos demais membros da sociedade, viola o princípio constitucional da autorresponsabilidade. Assim, no Estado Democrático de Direito, garantidor da liberdade de escolhas pessoais, a simples ingestão excessiva de álcool ou de substância análoga - ainda que a ciência médica, eventualmente, a considere oficialmente como ato lesivo à saúde - deve ser livre da

\footnotetext{
${ }^{203}$ Ressaltando a natureza discriminatória de tais incriminações, a lição de Miguel Reale Júnior: "Algumas figuras contravencionais, de maior incidência repressiva na Primeira República, especialmente no Rio de Janeiro e em São Paulo, no esforço de aparentar um país "civilizado", foram agasalhadas no texto de 1941. $\mathrm{Na}$ verdade, constituíam apenas uma questão social então tratada de forma discriminatória como problema social: as contravenções de vadiagem, mendicância e embriaguez, e que hoje ressurgem na proposta odienta da tolerância zero." (REALE JÚNIOR, Miguel. Prefácio. In: SALVADOR NETTO, Alamiro Velludo (Coord.). Comentários à Lei das Contravenções Penais, cit., p. 13).
} 
intervenção estatal ou, ao menos, livre da intervenção penal estatal. Para colocar em termos ainda mais claros, embriagar-se ou até mesmo viver no alcoolismo integram o direito ao livre desenvolvimento da personalidade da pessoa, a sua autodeterminação, podendo-se cogitar de uma intervenção do Estado legítima somente no campo administrativo ${ }^{204}$ ou por meio de campanhas informativas ${ }^{205}$, jamais se legitimando a atuação na seara penal.

Por fim, a terceira figura pretende punir a embriaguez pública que ponha em perigo a "segurança alheia". Aqui, o problema não parece estar na construção de um tipo paternalista, mas na vagueza ${ }^{206}$ e na desnecessidade da figura penal, tendo em vista a existência outras figuras penais mais adequadas, tais como o crime de perigo para a vida ou saúde de outrem (art.132 do Código Penal) ${ }^{207}$ e o de embriaguez na condução de veículo automotor (art.306 do Código de Trânsito Brasileiro) ${ }^{208}$.

\subsection{Jogos de azar e jogo do bicho}

No mesmo Capítulo VII ("Das contravenções relativas à polícia de costumes”) da Lei de Contravenções Penais, chamam também a atenção, no contexto deste trabalho, as vetustas $^{209}$ figuras relativas aos jogos de azar e ao jogo do bicho ${ }^{210}$.

De uma forma geral, pune-se aquele que estabelece, explora, realiza ou participa, visando à obtenção do prêmio, de jogo de azar ou jogo do bicho. Nos termos da lei,

\footnotetext{
${ }^{204}$ Oferecendo-se instituições públicas para o tratamento do alcoolismo, por exemplo.

${ }^{205}$ Importante lembrar que o Estado e as concessionárias de serviço público (Redes de TV etc) faturam bilhões de reais por ano com tributos e publicidade massiva de marcas de cerveja. Vale a reflexão: se o Estado - ainda que indiretamente - lucra, tolera e até fomenta o consumo de bebidas alcoólicas, como pretender legitimar a sua intervenção penal sobre aqueles que se embriagam?

${ }^{206}$ Afinal, o que seria considerado embriaguez? Segundo Renato de Mello Jorge Silveira, "a própria noção de embriaguez é ampla. Não se podendo utilizar a noção expressa na lei de trânsito, já que aquela noção é restrita à condução de veículo automotor, parece, o mais correto, a específica colocação médica, segundo a qual ela se confunde com uma intoxicação aguda". (Lei das Contravenções Penais - parte especial capítulo VII: das contravenções referentes à política de costumes - arts. 59 a 65, cit., p. 289).

207“Art. 132 - Expor a vida ou a saúde de outrem a perigo direto e iminente"

208“Art. 306. Conduzir veículo automotor, na via pública, estando com concentração de álcool por litro de sangue igual ou superior a 6 (seis) decigramas, ou sob a influência de qualquer outra substância psicoativa que determine dependência"

${ }^{209}$ Cf. PIERANGELI, José Henrique. op. cit. p. 266 e 316.

${ }^{210}$ Art.50 e 58 do Decreto-Lei 3.688(LCP). Embora vetustas, é muito frequente observar, ainda atualmente, a chegada de vans lotadas aos Juizados Especiais Criminais, com dezenas de pessoas detidas em um salão de jogos de azar, englobando os donos do local, o gerente, os funcionários e apostadores.
} 
considera-se jogo de azar aquele em que o ganho e a perda dependam exclusiva ou principalmente da sorte, as apostas sobre corrida de cavalos não autorizadas e as apostas sobre qualquer outra competição esportiva. E, considera-se jogo do bicho aquele em que um dos participantes, considerado comprador ou ponto, entrega certa quantia com a indicação de combinações de algarismos ou nome de animais, a que correspondem números, ao outro participante, considerado o vendedor ou banqueiro, que se obriga mediante qualquer sorteio ao pagamento de prêmios em dinheiro. Dessa maneira, o jogo do bicho acaba se configurando, por raciocínio lógico, espécie do gênero "jogos de azar"211.

Logo de início, evidencia-se enorme dificuldade em se identificar o bem jurídico passível de lesão com a prática das condutas em análise. Seria a chamada "polícia de costumes" ou os "bons costumes"212? Ou seria o patrimônio individual do apostador ou jogador?

No que tange à primeira hipótese, como explicitado no item anterior, "polícia de costumes" ou "bons costumes" não se afiguram como bem jurídico-penais legítimos no Estado Democrático de Direito, restando, desde já, afastados.

Passando à segunda possibilidade, cumpre destacar que elevar à condição de infração penal a conduta de dispor livremente de seu próprio patrimônio significaria a verdadeira consagração de um tipo paternalista, ao mesmo tempo, direto - pela incidência do poder punitivo sobre o próprio indivíduo lesionado - e indireto - pela incidência sobre

\footnotetext{
${ }^{211}$ Art.58 do Dec. Lei 6259/44.

${ }^{212}$ Afirmando os "bons costumes" como bem jurídico nos jogos de azar, cf. NUCCI, Guilherme de Souza. Leis penais e processuais penais comentadas. 3. ed. São Paulo: Ed. Revista dos Tribunais, 2008. p. 194. O autor afirma que "a ideia, ainda prevalente, é manter as pessoas afastadas desse tipo de jogo, que não depende da habilidade para ganhar (como, por exemplo, os jogos esportivos), mas de mera sorte". Prossegue destacando que "essa situação pode levar à perda patrimonial, ao vício e aos desmandos de toda ordem". Em sentido semelhante, mesclando bons costumes com proteção do patrimônio da família, Marcelo Valdir Monteiro: "A intenção do legislador é preservar os bons costumes, exaltando as normas de condutas aceitas pela sociedade como adequadas e reprimindo atos violadores da moral e dos bons costumes, por meio da reprimenda penal. (...). Os arts. 50/58 tratam de condutas relativas ao jogo. Num regime que valoriza o trabalho e condena o ganho fácil de dinheiro o Estado regulamenta o jogo, no intuito de valorizar o comportamento útil dos indivíduos e de preservar o patrimônio da família, uma vez que os males causados pelo vício da jogatina são capazes de arruinar toda a estrutura de uma família, bem como de levar o indivíduo a prática de crimes para manter o seu vício." O mesmo autor, ainda preso ao paradigma do Estado Legal de Direito, chega a afirmar que, embora mudem de acordo com a 'evolução' da sociedade, "os costumes não revogam leis" e que, portanto, todas as contravenções penais relativas ao jogo "continuam tipificadas na legislação penal como contravenções penais e somente uma nova lei pode descriminalizar a conduta". (Lei das Contravenções Penais - parte especial - capítulo VII: das contravenções referentes à política de costumes - arts. 50 a 58. In: SALVADOR NETTO, Alamiro Velludo (Coord.). Comentários à Lei das Contravenções Penais, cit., p. 235-236).
} 
aquele explora o jogo e, suspostamente, lesiona o apostador ${ }^{213}$-, ambas as formas incompatíveis com o princípio da autorresponsabilidade.

Importante destacar que as figuras penais, em momento algum, exigem a ocorrência de fraude ou qualquer tipo de engano em desfavor do apostador. Pune-se o jogo limpo, dependente única ou principalmente da sorte, partindo-se do pressuposto de que esta não seria uma boa forma de se gastar o próprio dinheiro.

Ocorre que, indubitavelmente, integra a autodeterminação do indivíduo a livre disposição de seu patrimônio, segundo os seus próprios gostos e opções, não podendo o Estado intervir por meio de seu poder punitivo penal para forçar alguém a se abster de gastar seu dinheiro de determinada forma. Em outras palavras, cada indivíduo dispõe de seu patrimônio do modo que desejar, ainda que seja lançando-o à própria sorte, como ocorre no caso dos jogos de azar.

Há, ainda, outro ponto importante nesta discussão, qual seja, o fato de ser o próprio Estado, por meio de diversas loterias, o principal explorador de jogos de azar. Como dizer, então, que esta conduta violaria os bons costumes? Da mesma forma, como sustentar que o Estado estaria preocupado com o patrimônio individual do apostador?

Por essa razão, há quem sustente, talvez na busca desesperada por uma justificativa plausível, que o bem jurídico passível de lesão aqui seria, na realidade, um certo monopólio do Estado, o qual seria o único autorizado a atuar como explorador de jogos de azar e, portanto, o único a se beneficiar com os bilhões e bilhões de reais auferidos com o jogo ${ }^{214}$.

Sem entrar na discussão acerca da existência e validade deste suposto monopólio estatal e sobre a sua legitimidade como bem-jurídico penal, importa apenas destacar que as regras do Direito Administrativo tendem a se mostrar mais adequadas e suficientes para regular tal questão, até mesmo em atenção ao princípio da intervenção penal

\footnotetext{
${ }^{213}$ Cf. ESTELLITA, Heloisa. op. cit., p. 341.

${ }^{214}$ Nesse sentido, p. ex., GOMES, Luiz Flávio. Jogo do bicho: bem jurídico e descriminalização parcial. Boletim IBCCRIM, São Paulo, n.56, p. 5, jul. 1997. O autor sustenta que, por essa razão, somente seria legítima a repressão ao agente que explora o jogo - por ser este quem, de fato, violaria o monopólio estatal - e não ao apostador. Existe, também, quem defenda que o bem jurídico seria a fazenda pública, tendo em vista o prejuízo financeiro estatal com a quebra do monopólio. Assim: SILVA FORNÉ, Diego. Juegos de azar, tutela penal de la propiedad y delito de juego de la mosqueta. Revista de Derecho Penal, Fundación de Cultura Universitária, Montevideo, n. 12, p. 87-102, jul. 2001.
} 
mínima $^{215}$. No Estado Democrático de Direito, a intervenção do poder punitivo não se legitima como forma de forçar o indivíduo a cumprir meros regulamentos, evitando-se, assim, uma inapropriada administrativização do Direito Penal.

Por fim, há também quem sustente que os jogos de azar estariam relacionados a outros delitos, tais como a lavagem de dinheiro, corrupção e o tráfico de drogas e armas, sendo campo fértil para a atuação de organizações criminosas ${ }^{216}$, e que, por isso, devem permanecer como infração penal. Tal raciocínio se mostra absurdo e desprovido de qualquer base científica. A repressão penal a determinada conduta somente se legitima se esta, por si mesma, é ofensiva a algum bem jurídico fundamental. Quer dizer que o Estado deveria incriminar a compra de um apartamento ou a abertura de um comércio porque tais condutas também estão relacionadas à lavagem de dinheiro e ao crime organizado? E, ainda, deveria elevar o casamento à condição de crime porque estão relacionados aos homicídios passionais? Deveria, da mesma forma, criminalizar a compra de veículo automotor por ser este um "foco" de lesões corporais no trânsito? Uma coisa é uma coisa, outra coisa é outra coisa. Isso sem falar no fato de que talvez seja justamente a proibição do jogo a causa principal de sua suposta relação com condutas criminosas diversas. Não é possível justificar uma proibição com as consequências da própria proibição.

\subsection{Crimes sexuais}

O tema sexual sempre foi objeto de inquietação humana, e sob o seu espectro, mitos foram criados, religiões edificadas, estruturas sociais montadas ${ }^{217}$, constituindo fértil material de estudo para inúmeras áreas das ciências.

As regras de conduta neste campo da experiência humana também sempre existiram, e, ao longo da história da humanidade, apresentaram íntima relação com preceitos religiosos e morais. O Direito, transformado no centro de regulação de condutas

\footnotetext{
${ }^{215}$ Sustentando a conveniência de se remeter estas infrações ao âmbito do Direito Administrativo sancionador, cf. SILVA FORNÉ, Diego. op. cit., p. 91.

${ }^{216}$ Nesse sentido, p. ex., MONTEIRO, Marcelo Valdir. op. cit., p. 268.

${ }^{217}$ SILVEIRA, Renato de Mello Jorge. Por um novo direito penal sexual: a moral e a questão da honestidade. Revista Brasileira de Ciências Criminais, São Paulo, v. 9, n. 33, p. 133, jan./mar. 2001.
} 
humanas, de certa forma, incorporou tais exigências religiosas e morais, valendo-se o Estado, muitas vezes, de seu poder punitivo para impor determinados padrões dominantes no campo sexual.

Nesse contexto, pode-se dizer, seguramente, que a história do Direito Penal sexual brasileiro é profundamente marcada pela tentativa de imposição de condutas moralmente aceitas, com a extensão do poder punitivo àqueles comportamentos tidos unicamente como contrários à moral sexual dominante ${ }^{218}$, sendo, portanto, campo fértil para a atuação paternalista estatal.

Estabelecendo como marco inicial de análise o Código Penal do Império de 1830, em um capítulo intitulado "Dos crimes contra a segurança da honra"219 , é possível observar a existência de diversas expressões de cunho eminentemente moral : mulher virgem, mulher honesta, prostituta, e adultério são apenas alguns exemplos. Destacam-se os crimes de deflorar mulher virgem (art.219), sedução de mulher honesta (art.224), rapto (art.226 e 228), além do crime de adultério (art.250 e 251). Chama atenção, ainda, a obrigação de dotar a ofendida como uma das penas cominadas, o casamento como causa de exclusão de muitos crimes e o fato de a ofendida ser prostituta configurar crime privilegiado. O Código Penal Republicano de 1890, no título denominado "Dos crimes contra a segurança da honra e honestidade das famílias e do ultraje público ao pudor" ${ }^{220}$, praticamente repete as expressões do Código anterior, destacando-se o crime de ultraje público ao pudor ${ }^{221}$.

O Código Penal de 1940, no título "Dos crimes contra os costumes"222, embora tenha trazido alterações importantes, manteve grande parte dos dispositivos de cunho eminentemente moral. Permaneceram, por exemplo, as expressões mulher honesta e mulher virgem, e os crimes de rapto e de adultério. Foram criadas as figuras do lenocínio, tráfico de mulheres e outras relacionadas à prostituição.

\footnotetext{
${ }^{218}$ Acerca do tema, Alessandra Greco e João Daniel Rassi afirmam que "no Brasil, assim como em outros países, o conteúdo moral sempre esteve presente, de forma preponderante, como elemento orientador da legislação penal frente ao sexo." (Crimes contra a dignidade sexual. São Paulo: Atlas, 2010. p. 128). No mesmo sentido, SILVEIRA, Renato de Mello Jorge. Por um novo direito penal sexual: a moral e a questão da honestidade, cit., p. 138.

${ }^{219}$ Capítulo II, art.219 e seg.

${ }^{220}$ Título VIII, art. 266 e seg.

221“"Art. 282. Offender os bons costumes com exhibições impudicas, actos ou gestos obscenos, attentatorios do pudor, praticados em logar publico ou frequentado pelo publico, e que, sem offensa á honestidade individual de pessoa, ultrajam e escandalisam a sociedade".

${ }^{222}$ Título VI, art.213 e seg.
} 
No campo do Direito Penal sexual, a redação original do Código de 1940 vigorou, na sua integralidade, até o ano de $2005^{223}$, quando, amparado em uma tendência mundial $^{224}$, iniciou-se um processo lento de reforma. Passados mais de 40 anos de vigência do Código Penal de 1940 e quase 25 anos da promulgação da Constituição de 1988, a primeira reforma dos chamados crimes sexuais operou-se com a Lei $\mathrm{n}^{\circ}$ 11.106/2005, que, principalmente, teve o condão de revogar os crimes de sedução (art.217), rapto (art.219 a 222) e adultério (art.240) ${ }^{225}$, expurgar a expressão "mulher honesta" (arts.215, 216 e 219), excluir as causas de extinção da punibilidade (art.107, VII e VIII) e de aumento (art.226,III) relacionadas ao casamento, e substituir o crime de "tráfico de mulheres" (art.231) por "tráfico de internacional de pessoas" (art.231) e por "tráfico interno de pessoas" (art.231-A) ${ }^{226}$.

Em seguida, coube à Lei $\mathrm{n}^{\circ} 12.015 / 2009$ a tarefa de dar continuidade às mudanças. Alterou-se a denominação do título para "Dos crimes contra a dignidade sexual" (Título VI). Atendendo às tendências de igualdade de gênero já manifestadas na reforma anterior, expurgou-se a expressão "mulher", substituído-a pelo termo "alguém" (art.213 e 215) e operou-se a unificação dos crimes de estupro e atentado violento ao pudor (art.213). Nos tipos relacionados à prostituição, acrescentou-se a expressão "ou outra forma de exploração sexual" (arts.228, 229, 231 e 231-A).Criou-se um capítulo específico para tratar “dos crimes contra vulnerável” (Capítulo II) ${ }^{227}$.

Como se observa, as alterações acima aludidas revelam, a toda evidência, um quadro de ampla e, até certo ponto, profunda reforma do Direito Penal sexual brasileiro. Embora tenha apresentado significativos avanços, não há como deixar de observar que legislação penal sexual brasileira ainda apresenta diversas incriminações de caráter

\footnotetext{
${ }^{223}$ Houve uma alteração pontual no ano de 2001 (Lei n ${ }^{\circ} 10.224$ ), com a inclusão do crime de assédio sexual (art.216-A).

${ }^{224} \mathrm{~A}$ partir da década de 70 do século XX, o desenvolvimento da teoria do bem jurídico-penal, sobretudo com a elaboração de uma concepção crítica e político-criminal, vinculando-o à ideia de limitação do poder punitivo estatal, orientou amplas modificações do direito penal sexual de diversos país, mitigando-se, de um modo geral, o conteúdo moralista. Merecem destaque a Alemanha (a partir da década de 1970), a Espanha (Reforma de 1989 e Código Penal de 1995), a Itália (Reforma de 1996) e Portugal (Revisão de 1995). Cf. SILVEIRA, Renato de Mello Jorge. Crimes sexuais. São Paulo: Quartier Latin, 2008. p. 45-62.

${ }^{225}$ Embora situado no título "Dos crimes contra a família", justifica-se a sua inserção aqui diante de sua forte relação com a chamada moral pública sexual.

${ }^{226}$ Para uma visão geral dessas mudanças, cf. GRECO, Alessandra Orcesi Pedro; RASSI, João Daniel. op. cit., p. 128-136.

${ }^{227}$ Optou-se por destacar aqui apenas as principais mudanças relacionadas ao tema ora em estudo. Para uma visão detalha das mudanças, cf. GRECO, Alessandra Orcesi Pedro; RASSI, João Daniel. op. cit., p. 137 e seg. e PIERANGELI, José Henrique; SOUZA, Carmo Antônio de. Crimes sexuais. Belo Horizonte: Del Rey, 2010.
} 
exclusivamente moral, nitidamente paternalistas, afrontando cabalmente, pois, o princípio da autorresponsabilidade expresso na Constituição Federal de $1988^{228}$.

Primeiramente, necessário destacar que o ato sexual, qualquer que seja, integra, essencialmente, a esfera da intimidade individual. A manifestação da sexualidade é, por excelência, um ato privado, que só diz respeito àquela única pessoa e, eventualmente, àqueles participantes concordantes. Em um Estado pluralista, tolerante, cada indivíduo é livre para expressar a sua sexualidade da forma como lhe parecer melhor, desenvolvendo livremente a sua personalidade também no âmbito sexual, por mais minoritária ou única que seja a sua conduta ${ }^{229}$.

Dessa forma, não se mostra legítima, no Estado Democrático de Direito, pluralista e laico, a atuação do poder punitivo estatal como meio de imposição de uma moralidade sexual dominante, na tentativa de dizer, ainda sob forte influência da igreja, o que é "bom" e o que "não é bom" ou o que é "moral" e o que é "imoral" para o cidadão, podendo cada indivíduo escolher a que "moral sexual" deseja se filiar ou não se filiar a nenhuma. Forma do ato sexual, número de parceiros, frequência, existência de recompensa - em dinheiro ou não , e muitas outras, são opções exclusivas dos participantes do ato sexual. Em resumo, cada indivíduo é livre para dispor sexualmente de seu próprio corpo.

Por essa razão, não é possível a invocação dos chamados "bons costumes" ou da "moralidade pública sexual" como bem jurídico legítimo em matéria sexual, expressões que revelam típica postura paternalista do Estado $^{230}$, contrariando o princípio da autorresponsabilidade.

\footnotetext{
228“O Estado não deve assumir pautas meramente paternalistas, mas garantir com fervor a autodeterminação, a liberdade sexual dos sujeitos na conformidade de suas reais capacidades de discernimento". (SALVADOR NETTO, Alamiro Velludo. Estupro bilateral: um exemplo limite. Boletim IBCCRIM, São Paulo, ano 17, n. 202, p. 8-9, set. 2009).

${ }^{229}$ "Na realidade, de paternalismo a simples moralismo, em se tratando de questões que unicamente tenham o escopo a restrição da liberdade de indivíduos adultos pela mera suposição de não serem eles aptos a uma livre escolha de como agir em determinado tempo, estas devem ser repudiadas. Não se pode aceitar que se venha a considerar que uma pessoa adulta não possa atuar livremente quanto ao sexo. Seria de vilania moral, se não paternalista, entender-se que a proteção de indivíduos face ao que o Estado entende ser danoso a si justifica um tolhimento da capacidade de autodeterminação. Se esta não é violada, nunca é de se admitir a violência maior do Estado ao criar leis restritivas da liberdade individual." (SILVEIRA, Renato de Mello Jorge. Crimes sexuais, cit., p. 150).

${ }^{230}$ Neste ponto, vale destacar as lições de Eugênio Raúl Zaffaroni: "El estado que pretende imponer una moral es inmoral, porque el mérito moral es producto de una elección libre frente a la posibilidad de elegir otra cosa: carece de mérito el que no pudo hacer algo diferente. Por esta razón el estado paternalista es inmoral, En lugar de pretender imponer una moral, el estado ético debe reconocer un ámbito de libertad moral, posibilitando el mérito de sus habitantes, que surge cuando se dispone de la alternativa de lo inmoral: esta paradoja lleva a la certera afirmación de que el derecho es moral, precisamente porque es la
} 
Da mesma forma, a eleição, feita pela atual redação do Código Penal, de uma certa "dignidade sexual" como bem jurídico nos crimes sexuais também é bastante criticável. Em primeiro lugar, porque a própria conceituação de dignidade sexual é, no mínimo, problemática, considerando a sua íntima relação com a expressão "dignidade da pessoa humana", termo este que atravessa um processo de extrema banalização e esvaziamento de sentido, sendo de difícil concretização a nível exigido pelo Direito Penal $^{231}$. Dessa forma, a tendência é entender que a "dignidade sexual" se afigura como expressão demasiadamente aberta, não sendo adequada para figurar como bem jurídico, sobretudo considerando a função deste de limitação do poder punitivo estatal ${ }^{232}$. É possível afirmar, ainda, que talvez seja exatamente essa abertura que permita a construção indevida de tipos paternalistas.

posibilidad de lo inmoral, vinculada íntimamente a la distinción entre conciencia jurídica y conciencia moral;(...)Como consecuencia de lo anterior, las penas no pueden caer sobre conductas que son, justamente, el ejercicio de la autonomía ética que el estado debe garantizar, sino sobre las que afectan el ejercicio de ésta. Conforme a esta decisión por el estado moral (y al consiguiente rechazo del estado paternalista inmoral), no puede haber delito que no reconozca como soporte fáctico un conflicto que afecte bienes jurídicos ajenos, entendidos como los elementos de que necesita disponer otro para autorrealizarse (ser lo que elija ser conforme a su conciencia" (ZAFFARONI, Eugenio Raúl. Derecho penal: parte general. 2. ed. Ediar: Buenos Aires, 2002. p. 127). Nesse sentido, Miguel Reale Júnior afirma que "não devem em um Estado de Direito Democrático constituir valores penalmente tutelados ou bem jurídico-penais convicções de cunho moral ou religioso, punindo-se, por exemplo, o homossexualismo ou a prática da quimbanda. (Instituições de direito penal, cit., p. 24). Na mesma linha, ROXIN, Claus. Derecho penal: parte general. Madrid: Civitas. 1997. p. 56.

${ }^{231}$ Não se intenciona, aqui, reduzir a importância da dignidade da pessoa humana, fundamento da República $\left(\mathrm{CF}, \operatorname{art} .1^{\circ}, \mathrm{III}\right)$. Pretende-se somente chamar a atenção para a sua inadequação para figurar como referência direta de bem-jurídico penal. Também criticando a utilização da dignidade humana para legitimar uma incriminação, destacando a possibilidade de atribuir-lhe um significado similar a uma "reprovabilidade moral", cf. ROXIN, Claus. Estudos de direito penal, cit., p. 39-44. Tentando construir uma noção de dignidade adequada ao atual modelo de Estado, a lição de Luís Greco: "Os problemas do conceito de dignidade humana são suficientemente conhecidos. $\mathrm{O}$ aspecto que nos interessa agora diz respeito a uma ambiguidade fundamental inerente a esse conceito. Poder-se-ia dizer que dignidade pode ser compreendida ou de perspectiva política - dignidade como autonomia, como direito de viver segundo seu próprio plano de vida, sua própria noção de vida boa; e que o conceito também pode ser compreendido de uma perspectiva perfeccionista - dignidade como virtude, como admirabilidade daquele que realiza certas excelências inerentes à vida boa. (...). O único sentido que pode interessar a um Estado liberal, que é um Estado que permanece neutro diante das diferentes noções de vida boa, é o primeiro, o conceito político de dignidade. Porque o conceito perfeccionista de dignidade equivale a elevar o Estado, um aparato dotado de poderes coercitivos, ao rol de juiz sobre a virtude de seus indivíduos". (Casa de prostituição (art. 229 do CP) e direito penal liberal: reflexões por ocasião do recente julgado do STF (HC 104.467). Revista Brasileira de Ciências Criminais, São Paulo, v. 19, n. 92, p. 448-449, set./out. 2011).

${ }^{232}$ Em sentido contrário, Alessandra Greco e João Daniel Rassi, concordando com a opção do legislador, ressaltam ser a dignidade sexual especificidade da dignidade da pessoa humana, identificável em dois planos: a dignidade individual, ligada ao exercício da autodeterminação sexual, e a dignidade social, ligada a um consenso de que o espaço adequado para as relações sexuais é o privado, admitindo a tutela penal de uma chamada moralidade sexual substantiva. (Crimes contra a dignidade sexual, cit., p. 59-62). Também concordando com a opção do legislador brasileiro: CERVINI, Raul. Prefácio. In: PIERANGELI, José Henrique; SOUZA, Carmo Antônio de. Crimes sexuais, cit. 
Além disso, no atual modelo de Estado, parece não se mostrar possível a distinção entre atos sexuais dignos e indignos, sendo mais apropriado falar-se em atos sexuais praticados com liberdade ou sem liberdade ${ }^{233}$. Afinal, existiria algum ato sexual livre, mas indigno? Indigno para quem? Para a sociedade? Não é por outro motivo que as reformas do Direito Penal sexual ocorridas na Alemanha, Espanha, Itália e Portugal, acabaram por, de um modo geral, consagrar a "liberdade de autodeterminação sexual",234 - ou simplesmente a "liberdade sexual" - como único bem jurídico constitucionalmente adequado ao Estado Democrático de Direito ${ }^{235}$.

Nada obstante, o Código Penal brasileiro, mesmo após as modificações operadas pela Lei $n^{\circ} 12.015 / 2009$, ainda apresenta incriminações que nada se relacionam com a

\footnotetext{
${ }^{233}$ Nesse sentido, a lição de Alberto Silva Franco, mesmo antes da Lei no 12.015/2009: "As pessoas podem expressar sua sexualidade através de uma gama de opções, todas elas respeitáveis já que, numa sociedade pluralista e laica, deve ser admitida a diversidade de valores e crenças a respeito dessa matéria. Só não pode encontrar suporte a sexualidade exercida com coerção ou explorada. Assim, para regular a sexualidade, não têm o menor relevo padrões éticos-sociais, os bons costumes, ou mesmo sentimentos gerais de moralidade sexual. O que, em verdade, interessa é a possibilidade de cada um direcionar livremente sua sexualidade. (...). Os delitos sexuais não poderiam mais permanecer sob o título 'Crimes contra os costumes' e deveriam migrar para o título 'Crimes contra a pessoa' e, em particular, no capítulo referente aos 'crimes contra a liberdade sexual'. O centro do sistema de crimes sexuais se deslocaria, então, da tutela de uma ordem, que impõe aos cidadãos adultos um determinado padrão de moralidade, para o da tutela, na esfera da sexualidade, da livre disponibilidade sexual do próprio corpo e da liberdade de optar por essa ou por aquela forma de exercício. (...) Em matéria de sexualidade , enquanto componente inafastável do ser humano, não se cuida de sexo digno ou indigno, mas tão somente de sexo realizado com liberdade ou sexo posto em prática mediante violência ou coação, ou seja, com nível mais ou menos de ofensa à autodeterminação sexual do parceiro. Destarte, toda lesão à liberdade sexual da pessoa humana encontra seu núcleo na falta de consensualidade. Fora daí não há conduta sexual que deva ser objeto de consideração na área penal" (FRANCO, Alberto Silva; STOCO, Rui (Coords.). Código Penal e sua interpretação, cit., p. 1018-1019).

${ }^{234} \mathrm{~A}$ "liberdade de autodeterminação sexual" pode ser compreendida em dois aspectos: um positivo, consistente na possibilidade de agir conforme a própria vontade no campo sexual; um negativo, consubstanciado na possibilidade de repelir atos que contrariem a vontade na esfera sexual. Cf. DÍEZ RIPOLLÉS, José Luis. El objeto de protección del nuevo derecho penal sexual. Revista de Derecho Penal y Criminología, Madrid, 2. época, n. 6, p. 71, jul. 2000.

235، Sin duda, la libertad sexual se ha consolidado como el objeto de proteccíon que justifica la intervenciones jurídico-penales en las prácticas sexuales de los ciudadanos. Con su tutela no se aspira simplemente a garantizar a toda aquella persona que posea la capacidad de autodeterminacíon sexual su efectivo ejercicio, sino que el ojectivo es más ambicioso: Se quiere assegurar que los comportamentos sexuales en nuestra sociedade tengan siempre lugar em condiciones de libertad individual de los partícipes o, más brevemente, se interviene con la pretensíon de que toda persona ejerza la actividad sexual em libertad." (Id. Ibid., p. 69) Entendendo a liberdade de autodeterminação sexual como único bem jurídico legítimo, cf., p. ex., SILVEIRA, Renato de Mello Jorge. Por um novo direito penal sexual: a moral e a questão da honestidade, cit., p. 157 O autor vai mais longe e afirma que somente condutas praticadas com violência ou grave ameaça deveriam ser objeto da norma penal sexual (Id. Ibid., p. 158), defendendo, portanto, mesmo antes da Lei 12.015/2009, uma necessidade de ampla descriminalização no Brasil. (Id. Crimes sexuais, cit., p. 365-382).
} 
ofensa à liberdade de autodeterminação sexual do indivíduo ${ }^{236}$, e que, acabam por violar o princípio da autorresponsabilidade ${ }^{237}$, conforme se verá detalhadamente abaixo.

\section{A) Mediação para servir a lascívia de outrem}

O tipo do art.227 do Código Penal incrimina a conduta de "induzir alguém a satisfazer a lascívia de outrem". Em outras palavras, de forma absolutamente absurda, admite-se a intervenção do poder punitivo estatal sobre aquele que simplesmente induz uma pessoa a satisfazer os desejos sexuais de alguém, a praticar qualquer ato sexual com um terceiro determinado ${ }^{238}$. O objetivo, aqui, parecer ser evitar uma banalização do sexo, seguindo os supostos padrões morais dominantes.

A criminalização é duplamente paternalista, por partir do pressuposto de que o indivíduo é facilmente influenciável e não é capaz de decidir os rumos de sua própria vida sexual, e por pretender impor determinado padrão de conduta no campo sexual, padrão este, certamente, influenciado por preceitos religiosos que defendem o ato sexual somente com a finalidade de procriação. Trata-se, em verdade, da criminalização do exercício da própria liberdade sexual, em favor de uma pretensa moral dominante ${ }^{239}$.

Sustenta-se que o bem jurídico passível de lesão, neste caso, seria "os bons costumes" ou a "moralidade pública sexual" ${ }^{240}$, os quais, como visto, são inadmissíveis no Estado Democrático de Direito ${ }^{241}$.

\footnotetext{
${ }^{236} \mathrm{Na}$ realidade, na tentativa de impor um padrão de conduta moralmente dominante, o Estado acaba por se transformar em um agente causador de lesão ao bem jurídico liberdade de autodeterminação sexual.

${ }^{237}$ Também relacionando o exercício da liberdade sexual com o livre desenvolvimento da personalidade garantido constitucionalmente, cf. DÍEZ RIPOLLÉS, José Luis. op. cit.

${ }^{238}$ Observa-se que o tipo não guarda qualquer relação com a prática da prostituição, ao contrário do sustentado por muitos autores. Comenta-se que, "se o induzimento se fizesse em relação a pessoa indeterminada, o crime seria o do art.228 do CP". (FRAGOSO, Heleno Cláudio. Lições de direito penal. São Paulo: Bushatsky, 1959. v. 3, p. 513).

239، Trata-se, em certa medida, de um exemplo evidente de paternalismo legal, já que limita aprioristicamente a liberdade quanto à disposição ao sexo (desde que de forma consentida), sem aparente dano à pessoa." (SILVEIRA, Renato de Mello Jorge. Crimes sexuais, cit., p. 336).

${ }^{240}$ Sustentando ser a "moralidade pública e sexual" o bem jurídico deste delito: GRECO, Alessandra Orcesi Pedro; RASSI, João Daniel. op. cit., p. 157. BITENCOURT, Cezar Roberto. Tratado de direito penal. 3. ed. São Paulo: Saraiva, 2008. v. 4. Este último autor chega ao ponto de afirmar ser este "um dos crimes mais degradantes e moralmente censuráveis, que a civilização, ao longo de toda a sua história, não conseguiu eliminar." (p. 59).

${ }^{241}$ No mesmo sentido, lembrando que essa fundamentação não é aceita desde "o nascimento da moderna teoria do bem jurídico depois da Segunda Guerra Mundial”, cf. GRECO, Luís. Casa de prostituição (art. 229 do CP) e direito penal liberal: reflexões por ocasião do recente julgado do STF (HC 104.467), cit., p. 444-445.
} 
Vale pontuar, apenas, que o $\S 2^{\circ}$ do dispositivo, responsável por trazer uma forma qualificada pela violência, grave ameaça ou fraude, é incompatível com o verbo nuclear do tipo ("induzir"). Na presença destes elementos, haverá constrangimento, não induzimento, e o crime será contra a liberdade sexual.

Trata-se de figura aberrante, prescindindo de maiores comentários, não recepcionada pela Constituição de 1988, devendo ser urgentemente extirpada do Código Penal ${ }^{242}$.

\section{B) Crimes relacionados à prostituição}

Pode-se dizer, de uma forma geral e prescindindo-se de uma análise histórica aprofundada, que a prostituição, entendida como a prática de ato sexual mediante contraprestação econômica, sempre foi objeto de longos debates religiosos, morais, e também jurídicos ${ }^{243}$.

Para o escopo do presente trabalho, interessa consignar que a atual redação do Código Penal brasileiro, embora não criminalize a prática da prostituição propriamente dita, traz uma série de tipos diretamente relacionados a ela. Trata-se dos crimes de favorecimento da prostituição $(\operatorname{art.228})^{244}$, manutenção de casa de prostituição $(\operatorname{art.229})^{245}$ e rufianismo $(\operatorname{art.230})^{246}$, tráfico internacional de pessoas $(\operatorname{art.231})^{247}$ e de tráfico interno de pessoas (art.231-A) $)^{248}$.

\footnotetext{
${ }^{242}$ Defendendo a necessidade de descriminalização da figura, cf., p. ex., FRANCO, Alberto Silva; STOCO, Rui (Coords.). op. cit., p. 1116-1117). SILVEIRA, Renato de Mello Jorge. Crimes sexuais, cit., p. 336 e 370.

${ }^{243}$ Cf. SILVEIRA, Renato de Mello Jorge. Crimes sexuais, cit., p. 321 e seg.

${ }^{244}$ Art. 228. Induzir ou atrair alguém à prostituição ou outra forma de exploração sexual, facilitá-la, impedir ou dificultar que alguém a abandone.

${ }^{245}$ Art. 229. Manter, por conta própria ou de terceiro, estabelecimento em que ocorra exploração sexual, haja, ou não, intuito de lucro ou mediação direta do proprietário ou gerente Recentemente o Supremo Tribunal Federal ratificou a constitucionalidade deste dispositivo no julgamento do HC 104.467/RS (Rel.Min.Carmen Lúcia.j.08/02/2011), apontando a "moralidade sexual" e os "bons costumes" como bens jurídicos. Para uma análise crítica detalhada desta decisão, cf. GRECO, Luís. Casa de prostituição (art. 229 do CP) e direito penal liberal: reflexões por ocasião do recente julgado do STF (HC 104.467), cit. Segundo o autor, "perdeu o STF áurea oportunidade de dar um passo adiante na realização de um Estado liberal, isto é, de um Estado para o qual decisões que dizem respeito à vida boa, a virtude de uma pessoa, têm de ser tomadas pela própria pessoa e não são assunto do Estado." (Id. Ibid., p. 438-439).

${ }^{246}$ Art. 230 - Tirar proveito da prostituição alheia, participando diretamente de seus lucros ou fazendo-se sustentar, no todo ou em parte, por quem a exerça.

${ }^{247}$ Art. 231. Promover ou facilitar a entrada, no território nacional, de alguém que nele venha a exercer a prostituição ou outra forma de exploração sexual, ou a saída de alguém que vá exercê-la no estrangeiro.

${ }^{248}$ Art. 231-A. Promover ou facilitar o deslocamento de alguém dentro do território nacional para o exercício da prostituição ou outra forma de exploração sexual.
} 
Sob forte influência de preceitos religiosos, parte-se, por evidência, de dois níveis de fundamentação: o primeiro é moralista e considera que a prostituição é ruim; o segundo é paternalista, porque a proibição, embora seja dirigida àqueles que vivem dos proveitos da prostituição alheia, é estabelecida para proteger a pessoa que se prostitui de ter o que ela deseja, sob o fundamento de que o Estado sabe melhor o que é bom para ela, ou seja, "não ser uma prostituta ou um prostituto"249.

Rompendo com qualquer tipo de eventual tabu, necessário consignar que o princípio da autorresponsabilidade abrange a livre disposição sexual do próprio corpo, em todas as formas possíveis. Qualquer indivíduo é livre para escolher a prostituição como prática eventual ou como meio habitual de vida, já que esta não causa dano direto a ninguém. Compete unicamente aos participantes da relação definir se o ato sexual será praticado em troca de prazer carnal, de promessa de casamento, de herança, de emprego, de participação em programa de televisão, de amizade, de geração de um filho etc, ou mediante pagamento em dinheiro.

$\mathrm{O}$ ato de prostituir-se, na realidade, concretiza a ideia de liberdade autodeterminação sexual, no livre exercício da personalidade, não sendo legítima a imposição, por parte do Estado, pelo uso de seu poder punitivo, de qualquer limite à disposição sexual do próprio corpo, ainda que indiretamente. Por essa razão, afigura-se equivocada a tentativa da Lei $n^{\circ} 12.015 / 2009$ de classificar a prostituição como espécie

\footnotetext{
${ }^{249}$ ESTELLITA, Heloisa. op. cit., p. 337. "Tudo o que há são argumentações exclusivamente morais que partem de valorações religiosas do tipo "o corpo é sagrado e não deve ser comercializado" ou "o sexo deve ser praticado somente na constância do matrimônio, com amor, e única e exclusivamente para procriação". (VIANNA, Túlio. Legalizar as casas de prostituição. Fórum, São Paulo, p. 18-19, 10 nov. 2011). "No contexto de um Estado Democrático de Direito, fundado no pluralismo político e na dignidade humana, a política criminal deve materializar o reconhecimento do livre desenvolvimento da personalidade dos cidadãos. Desse modo, a intervenção penal é incompatível com a pretensão de limitar tal desenvolvimento conforme opções morais, mesmo majoritárias, que não sejam próprias do indivíduo. Sob tal perspectiva é que se deve examinar a tutela penal das situações envolvendo a prostituição. (...). Em primeiro lugar, observa-se que em todos os tipos mencionados está-se diante do emprego do Direito Penal para proibir comportamentos de terceiros que concorrem na pretensa autolesão do indivíduo, o que já seria inadmissível no contexto democrático. Antes disso, verifica-se nem mesmo ser possível identificar a autolesão em tais casos, haja vista a ausência de interesse individual identificável quando a atividade sexual decorrer da liberdade de autodeterminação do agente. De fato, nenhum dos comportamentos incriminados viola a autodeterminação sexual, justificando-se sob uma perspectiva histórica de repressão ao que se considera imoral, a partir da ideia de que indivíduos adultos não são aptos a eleger suas formas de agir em relação ao sexo." (BECHARA, Ana Elisa Liberatore Silva. A prostituição deve ser legalizada? Sim. Revista da OAB, São Paulo, v. 373, p. 12-12, 2012).
} 
do gênero exploração sexual ${ }^{250}$. Exploração sexual de quem? De quem se prostitui ou de quem paga pelos serviços? Quem é a vítima?

Ressalte-se que nenhum dos tipos penais relacionados à prostituição traz qualquer exigência quanto à ocorrência de violência, grave a ameaça ou fraude, o que os elevaria à condição de crime contra a liberdade sexual ${ }^{251}$. Qual seria, então, o bem jurídico passível de lesão nestes delitos?

Há quem afirme ser a própria dignidade do prostituto ou da prostituta, os quais sempre se encontrariam em situação de vulnerabilidade, diante de um contexto de desigualdade social, econômica, educacional e outras, o que justificaria a essa atuação paternalista indireta do Estado. Tal visão se mostra equivocada por vários motivos ${ }^{252}$. Primeiramente, porque, novamente, parte-se da afirmação moralista de que a prostituição é necessariamente ruim, e de que ela, portanto, nunca pode ser objeto da livre escolha de alguém. Baseia-se, também, na construção de uma preconceituosa presunção absoluta de que todo aquele que se prostitui é pobre e com baixa educação formal, merecendo ser tutelado pelo Estado pater, mesmo contra a sua vontade ${ }^{253}$. Além disso, se de fato

\footnotetext{
${ }^{250}$ A inclusão da expressão aberta "ou outra forma de exploração sexual" pouco ou nada altera o quadro dos tipos que envolvem a prostituição. Afinal, quais seriam estas "outras formas de exploração"? Para uma crítica contundente dessa opção legislativa, cf. GRECO, Luís. Casa de prostituição (art. 229 do CP) e direito penal liberal: reflexões por ocasião do recente julgado do STF (HC 104.467), cit., p. 450-453.

${ }^{251}$ As ofensas à liberdade de autodeterminação sexual ficaram reservadas aos parágrafos desses dispositivos (art.228, $\S 2^{\circ}$, art.230, $\S 2^{\circ}$, art.231, $\S 1^{\circ}$, IV, e art.231-A, $\S 2^{\circ}$, IV), que trazem causas de aumento ou formas qualificadas ligadas ao emprego de violência, grave ameaça ou fraude.

${ }^{252}$ Nessa mesma linha, chamando atenção para uma chamada "tirania da dignidade", cf. abordagem crítica em GRECO, Luís. Casa de prostituição (art. 229 do CP) e direito penal liberal: reflexões por ocasião do recente julgado do STF (HC 104.467), cit., p. 446-453.

253،"Há homens e mulheres que se prostituem como opção, buscando os meios necessários à sua subsistência ou mesmo alcançar um nível de vida que não conseguiriam alcançar por outros meios, ou ainda, por mera faculdade de escolha. (...). Isso significa reafirmar que qualquer ser humano pode exercitar a sua liberdade individual e a sua própria sexualidade, sem que tenha que recorrer ao imaginário da sociedade de que está sendo vítima de uma privação social, causado pelo abuso praticado por aqueles que o exploram e compram seus serviços sexuais.” (FRANCO, Alberto Silva; STOCO, Rui (Coords.). op. cit., p. 1130). “Aqui não há vítima, pelo menos no sentido jurídico do termo, já que a mulher fez uma escolha por esta forma de ganhar a vida. É bem verdade que esta escolha pode não ter sido voluntária e que suas condições socioeconômicas talvez tenham sido determinantes em sua decisão, mas certamente foi uma escolha livre. Escolhas livres não são necessariamente voluntárias, no sentido de serem determinadas por um desejo íntimo independente das condições socioeconômicas em que se vive. O sistema capitalista é bastante perverso, já que permite a muito poucas pessoas escolherem voluntariamente se preferem ser médicas ou faxineiras; engenheiras ou serventes de pedreiro; advogadas ou traficantes de drogas; atrizes ou prostitutas, mas não se pode cair no determinismo simplista de afirmar que suas escolhas não sejam livres. Do contrário, boa parte dos traficantes de drogas e ladrões não poderiam também ser presos, pois seus crimes também não seriam escolhas livres" (VIANNA, Túlio. op. cit.). "Es indudable que Ia prestación de servicios sexuales es una actividad que da lugar muy a menudo a abusos e, incluso, a Ia esclavitud de Ias personas que Ia ejercen. No obstante, es necessário dejar de considerar a Ia prostitución como una actividad que sólo puede ser ejercida de forma obligada y es imprescindible entender que puede tratarse de una opción libremente asumida como una forma más de vida." (CARUSO FONTÁN, Viviana. Sobre la criminalización de las actividades
} 
houvesse essa tal ofensa à dignidade daquele que se prostitui, não haveria sentido em não criminalizar quem usufrui de seus serviços, o qual seria o principal agente lesivo. Por fim, esquece-se de que o poder punitivo estatal só deve atuar em último caso, não se legitimando, também por essa razão, a sua atuação paternalista, já que o Estado disporia de outros meios para minimizar situações específicas de vulnerabilidade extrema ${ }^{254}$, sem utilizar-se da coação física.

Na realidade, a maior parte dos autores defende ser a moralidade pública sexual ou os "bons costumes" o bem jurídico nos crimes relacionados à prostituição ${ }^{255}$. Assim, por mais que se tente, desesperadamente, colocar aquele que se prostitui na posição de vítima, é possível afirmar que se trata simplesmente da criminalização de atos que, pretensamente, atentariam contra a moral sexual dominante, na tentativa de impor um padrão de conduta fora da prostituição, em clara violação ao princípio da autorresponsabilidade, inadmissível no Estado Constitucional e Democrático de Direito ${ }^{256}$.

Vale pontuar que nem mesmo o crime de tráfico de pessoas, entendido como o mais grave daqueles relacionados à prostituição, merece outra interpretação. Criminalizase simplesmente a conduta daquele que atua no deslocamento de pessoas que desejam exercer a prostituição em determinado lugar diverso daquele que se encontravam anteriormente. Não há, no caput do dispositivo, referência a violência, grave ameaça, fraude ou, sequer, a exploração de suposta vulnerabilidade. O Estado mais uma vez, por meio do Direito Penal, busca interferir na escolha do indivíduo, infantilizando-o, na

relacionadas con la prostitución consentida. Revista de Derecho y Proceso Penal, Navarra, v. 1, n. 25, p. 31-44, 2011) "Afirmar-se que a prostituição em si não pode ser consentida porque ela se mostra contrária à dignidade humana é assumir um discurso apriorístico e moralista do tema, ignorando-se toda a complexidade que o envolve" (SILVEIRA. Renato de Mello Jorge. Dos crimes contra a dignidade sexual. In: REALE JÚNIOR, Miguel. (Coord.). Direito penal: jurisprudência em debate: crimes contra a saúde pública. Rio de Janeiro: GZ, 2012. v. 3, p. 69.

${ }^{254}$ Não se está a falar aqui, destaque-se uma vez mais, de pessoas não adultas ou com algum defeito quanto ao desenvolvimento mental.

${ }^{255}$ Nesse sentido, p. ex, GRECO, Alessandra Orcesi Pedro; RASSI, João Daniel. op. cit., p. 158 e seg. PIERANGELI, José Henrique; SOUZA, Carmo Antônio de. Crimes sexuais, cit., p. 117 e seg.

${ }^{256} \mathrm{Na}$ mesma linha da crítica aqui formulada: "Não se trata de regular a liberdade de autodeterminação de ninguém (por maiores que sejam os esforços em isso se provar), mas de aparentemente se proteger uma instituição abstrata da moralidade pública. (...). Não se vislumbra, em situações em que não seja real a presença de um constrangimento da figura prostituída, um atentado de nenhuma espécie. (SILVEIRA, Renato de Mello Jorge. Crimes sexuais, cit., p. 342). Também nesse sentido, defendendo a ilegitimidade da moral sexual e dos bons costumes como bem jurídico, e ressaltando a inconcebível presença de crimes sem vítima, FRANCO, Alberto Silva; STOCO, Rui (Coords.). op. cit., p. 1128 e seg. 
tentativa de impor aquilo que considera melhor para a sua vida, acabando, consequentemente, por violar a liberdade de autodeterminação sexual do cidadão ${ }^{257}$.

\section{C) Do ultraje público ao pudor}

A denominação do sexto capítulo do título "Dos crimes contra a dignidade sexual" indica a previsão de crimes contra o "ultraje público ao pudor", o que já está a sugerir, mais uma vez, considerando a dificuldade em se definir o que seria um tal "pudor público" ${ }^{, 258}$, tratar-se de condutas passíveis de lesionar apenas a aclamada moral pública sexual ou os bons costumes.

A primeira figura prevista é o crime de ato obsceno $(\operatorname{art} .233)^{259}$, sendo o termo obsceno um elemento normativo demasiadamente aberto e de difícil definição ${ }^{260}$, característica que abre espaço para o abuso do poder punitivo, com a criminalização de condutas inofensivas à liberdade de autodeterminação sexual. Sendo assim, sem prejuízo de uma análise à luz do princípio da intervenção penal mínima, o melhor parece ser a readequação da figura, passando a constar do tipo objetivo atos relevantes de exibicionismo que concretizem, sob o ponto de vista de uma vítima determinada, a participação em ato sexual - como expectador - contrariamente à sua vontade ${ }^{261}$. Dessa forma, imagina-se que restaria atendida a exigência de conduta lesiva à liberdade sexual.

\footnotetext{
257،A ideia de fundo, também aqui, é a de que a prostituição é ruim (fundamento moralista), proibindo alguém de "promover, intermediar ou facilitar a entrada no território nacional, de pessoa que venha exercer a prostituição ou a saída de pessoa para exercê-la no estrangeiro" (art.231) ou praticar essas condutas no território nacional (art.231-A) é uma forma de impedir que alguém se torne prostituta, para o seu próprio bem (paternalismo indireto). O crime também parece adequar-se à definição de paternalismo legal moralista." (ESTELLITA, Heloisa. op. cit., p. 339-340). No mesmo sentido, FRANCO, Alberto Silva; STOCO, Rui (Coords.). op. cit., p. 1138 e seg. SILVEIRA, Renato de Mello Jorge. Crimes sexuais, cit., p. 375-378. Uma alternativa seria adotar um tipo semelhante ao do Código Penal Português, o qual vincula o tráfico à ofensa à liberdade de autodeterminação sexual: “Art.169 - Quem, por meio de violência, ameaça grave, ardil ou manobra fraudulenta, levar outra pessoa à prática em país estrangeiro da prostituição ou actos sexuais de relevo, explorando a sua situação de abandono ou de necessidade, é punido com pena de prisão de 2 a 8 anos" Para uma visão geral do crimes sexuais no Código Penal português, após a reforma de 1995, cf. MOURAZ LOPES, José Antonio. Os crimes contra a liberdade sexual no Código Penal Português após a revisão de 1995. Revista Brasileira de Ciências Criminais, São Paulo, n. 10, p. 47-51, 1995. p. 47-51.

${ }^{258}$ Segundo Luiz Regis Prado, “o pudor público está intrinsicamente ligado aos costumes de um povo em determinado tempo e espaço, às condutas moralmente aceitas pela coletividade, estabelecendo limites às liberdades individuais públicas, no que tange ao comportamento que gravita em torno do sexo." (Curso de direito penal brasileiro. 7. ed. rev. atual. e ampl. São Paulo: Ed. Revista dos Tribunais, 2008. v. 2, p. 715).

${ }^{259}$ Art. 233 - Praticar ato obsceno em lugar público, ou aberto ou exposto ao público.

${ }^{260}$ FRANCO, Alberto Silva; STOCO, Rui (Coords.). op. cit., p. 1150.

${ }^{261}$ Em sentido semelhante, SILVEIRA, Renato de Mello Jorge. Crimes sexuais, cit., p. 378-380. FRANCO, Alberto Silva; STOCO, Rui (Coords.). op. cit., p. 1156-1159. Este último seja a sugerir uma nova redação
} 
Já a figura de escrito ou objeto obsceno (art.234) criminaliza a conduta de "fazer, importar, exportar, adquirir ou ter sob sua guarda, para fim de comércio, de distribuição ou de exposição pública, escrito, desenho, pintura, estampa ou qualquer objeto obsceno", abrangendo, ainda, aquele que vende, distribui, ou expõe à venda tais objetos, e aquele que realiza representação teatral, cinematográfica, audição, recitação ou qualquer outro espetáculo de caráter obsceno (parágrafo único).

Trata-se, simplesmente, da criminalização da pornografia para adultos. O Estado, de forma moralista, novamente influenciado por preceitos religiosos, considera a pornografia um mal e, por essa razão, objetiva impedir o seu acesso a cidadãos adultos e com pleno desenvolvimento mental, em mais uma atuação paternalista indireta explícita ${ }^{262}$.

No Estado Democrático de Direito, pluralista por excelência, o princípio da autorresponsabilidade garante a cada um a possibilidade de escolher se deseja ouvir rock ou samba, se deseja estudar latim ou grego, se deseja manter os cabelos curtos ou longos, assim com se deseja consumir pornografia ou arte contemporânea.

Como se não bastasse, é possível verificar, ainda, sob o prisma do indivíduo sobre o qual recai a incriminação, grave violação ao princípio constitucional da liberdade de expressão $\left(\mathrm{CF}, \text { art.5 }{ }^{\circ}, \mathrm{IX}\right)^{263}$, o qual aparece mitigado, de forma ilegítima, unicamente para o atendimento de padrões ligados à moralidade pública sexual.

\subsection{Charlatanismo e curandeirismo}

O Código Penal traz, na parte referente aos crimes contra a saúde pública, os tipos de charlatanismo (art.283) ${ }^{264}$ e curandeirismo (art.284) ${ }^{265}$. De modo geral, apenas pela leitura dos dispositivos, pode-se afirmar que se trata da criminalização do ato de anunciar, oferecer ou realizar tratamentos de saúde não convencionais, ou, em outras palavras,

\footnotetext{
legal: "Importunar outra pessoa, praticando perante ela e sem o seu consentimento, relação sexual vaginal, anal ou oral, a introdução de objetos por quais das duas primeiras vias, ou o ato de masturbar-se ou o de exibir órgãos genitais".

${ }^{262}$ Nesse sentido: SILVEIRA, Renato de Mello Jorge. Crimes sexuais, cit., p. 348-356.

${ }^{263}$ Nesse sentido: FRANCO, Alberto Silva; STOCO, Rui (Coords.). op. cit., p. 1162-1164. GRECO, Alessandra Orcesi Pedro; RASSI, João Daniel. op. cit., p. 173.

264،Art. 283 - Inculcar ou anunciar cura por meio secreto ou infalível”.

265“Art. 284 - Exercer o curandeirismo: I - prescrevendo, ministrando ou aplicando, habitualmente, qualquer substância; II - usando gestos, palavras ou qualquer outro meio; III - fazendo diagnósticos”.
} 
tratamentos desvinculados dos padrões médico-científicos oficiais, reconhecidos pela Ciência e pelo Estado.

Pelo que se depreende do texto legal, comete o crime de charlatanismo aquele que inculca ou anuncia cura por meio secreto ou infalível. E pratica curandeirismo aquela pessoa que, naturalmente sem habilitação técnico-científica oficial, se dedica ao tratamento de saúde por qualquer meio, seja prescrevendo, ministrando ou aplicando qualquer tipo de substância, seja valendo-se de gestos ou palavras ou, ainda, fazendo diagnósticos ${ }^{266}$.

Como se observa, os tipos penais não trazem a ocorrência de qualquer espécie de "fraude" como elemento essencial. Não se exige que aquele que inculca ou anuncia a cura acredite ou saiba da ineficácia ou da falibilidade do tratamento proposto. De igual forma, não se exige que aquele que exerce a atividade rotulada de curandeiro não confie na eficiência e na seriedade de seus serviços. Não faz parte do tipo objetivo, portanto, o ato de enganar alguém, por qualquer meio. Não há ninguém dizendo ser médico sem o ser ou que o tratamento é médico-científico, o que configuraria o crime de exercício ilegal da medicina (art.282). Trata-se, dessa forma, simplesmente da criminalização do tratamento alternativo, não cientificamente reconhecido ${ }^{267}$.

$\mathrm{Na}$ realidade, o que se constata é que a criminalização se baseia no seguinte fundamento paternalista: o Estado considera que os tratamentos não convencionais são ruins e, por essa razão, vale-se de seu poder punitivo para tentar proteger os cidadãos deste suposto

\footnotetext{
${ }^{266}$ Há quem diga, de forma aparentemente preconceituosa, que o curandeiro seria pessoa sempre rude, ignorante e inculta. Cf., p. ex., FRAGOSO, Heleno Cláudio. op. cit., v. 3, p. 740. PRADO, Luiz Regis. Curso de direito penal brasileiro. 7. ed. rev. atual. e ampl. São Paulo: Ed. Revista dos Tribunais, 2007. v. 3, p. 205. Cf., ainda, STF - HC 85.718/DF. Rel.Min.Cezar Peluso. j.18/11/2008. Em sentido contrário, defendendo que os curandeiros são "nem sempre pessoas ignorantes ou desprovidas de nível intelectual", cf. In: REALE JÚNIOR, Miguel. (Coord.). Direito penal: jurisprudência em debate: dos crimes contra a saúde pública. Rio de Janeiro: GZ, 2012. v. 3, p. 69.

267، A senha para participarem do jogo de sabres curativos parece não ter mudado: para ser legal é preciso ser científico" (SCHRITZMEYER, Ana Lúcia Pastore. Direito e antropologia: uma história de encontros e desencontros: julgamentos de curandeirismo e charlatanismo (Brasil - 1900/1990). Revista Brasileira de Ciências Criminais, São Paulo, v. 5, n. 18, p. 145, abr./jun. 1997). Alguns autores, por considerarem ser impossível a existência de "tratamento secreto ou infalível" (e, também, julgando ser impossível que alguém pense diversamente), conseguem enxergar a existência do elemento "fraude" no crime de charlatanismo. Nesse sentido, FRAGOSO, Heleno Cláudio. op. cit., v. 3, p. 738. BITENCOURT, Cezar Roberto. op. cit., v. 4, p. 207. PRADO, Luiz Regis. Curso de direito penal brasileiro, cit., v. 3, p. 201. NUCCI, Guilherme de Souza. Código Penal comentado. 8. ed. São Paulo: Ed. Revista dos Tribunais, 2008. p. 283-284. Este último, citando obra de Medicina Legal, chega a afirmar que "no segredo e a infalibilidade estão os pontos fundamentais do ilícito moral e legal, porque a medicina não pode agir por meios secretos, devendo ser franca e leal em sua atuação e também porque nunca pode pretender a infalibilidade." Pergunta-se: quem está a falar do exercício da medicina? O tipo, como visto, refere-se a tratamentos não convencionais.
} 
mal, mesmo contra a sua vontade individual ${ }^{268}$. Mais uma vez o Estado, infantilizando seus cidadãos, tratando-os como ingênuos e incapazes, tenta impor um padrão de conduta que considera "bom" ou "melhor", ignorando a opinião e a autonomia de cada indivíduo ${ }^{269}$.

O princípio da autorresponsabilidade assegura a cada pessoa a liberdade para decidir os rumos de sua própria vida, o que inclui, logicamente, a escolha da forma de tratamento de sua própria saúde. Mais do que isso, garante a liberdade para que cada pessoa decida se deseja ou não se submeter a algum tratamento, uma vez que o que a Constituição proclama é o direito à saúde ( $\operatorname{art} .6^{\circ}$ ) e não um inexistente dever à saúde. Por isso, não se mostra legítima a imposição pelo Estado, sobretudo valendo-se de seu poder punitivo, de uma determinada forma de tratamento de saúde, ainda que seja aquela considerada a melhor pela ciência médica oficial ${ }^{270}$.

Importante pontuar que grande parte das condutas tidas como charlatanismo ou curandeirismo é associada a específicas práticas religiosas ou místicas ${ }^{271}$, fundadas na crença da existência de um poder sobrenatural de curar doenças. É o caso, por exemplo, das chamadas "cirurgias espirituais", praticadas no âmbito de centros espíritas, ou das

\footnotetext{
268، Os artigos 283 e 284 do Código Penal trazem mais duas hipóteses de paternalismo indireto. A pessoa que pratica o charlatanismo ou o curandeirismo é punida para proteger outras pessoas, que possam ser iludidas ou enganadas, ou até menos que isso, já que esse elemento não está previsto em nenhum dos tipos penais. Mas aqui o engano ou a ilusão não e intenso o bastante para causar a falta de consentimento genuíno da vítima, o que implica dizer que a norma contém uma presunção direcionada a adultos, tratando-os como se fossem crianças, como se fossem sempre ingênuos e frágeis quando expostos a tais práticas." (ESTELLITA, Heloisa. op. cit., p. 340). Também reconhecendo o paternalismo estatal indireto nos crimes de charlatanismo e curandeirismo, BECHARA, Ana Elisa Liberatore Silva. Da teoria do bem jurídico como critério de legitimidade do direito penal, cit., p. 191.

${ }^{269}$ Luiz Regis Prado deixa evidente a justificação paternalista: "Claramente se vê qual é a principal consequência do exercício do curandeirismo: as pessoas, acreditando nessa prática, deixam de procurar o profissional capacitado, retardam o início do tratamento adequado ou, ainda, pode ser que nelas seja provocado algum mal." (Curso de direito penal brasileiro, cit., v. 3, p. 206).

270، Falar em obrigação jurídica do indivíduo em viver mais ou manter-se com saúde seria ir muito longe. Tal ponto de vista limitaria consideravelmente o direito à autodeterminação do indivíduo" (RIGOPOULOU, Maria. op. cit., p. 356). Pode-se admitir, no entanto, uma hipótese excepcional de legítima intervenção estatal, não necessariamente penal, no caso de doença grave altamente contagiosa, tendo em vista a possibilidade de dano direto não consentido a terceiros.

${ }^{271}$ Segundo Heleno Fragoso, o curandeirismo é "autêntica praga, aparecendo frequentemente junto a manifestações de religiosidade primitiva". (Lições de direito penal, cit., v. 3, p. 740). Em uma análise histórica, sob uma perspectiva antropológica, a lição de Ana Lúcia Pastore Schritzmeyer: "Podemos dizer que, desde o primeiro Código Penal republicano, promulgado em 1890, foi declarada uma verdadeira guerra médico-policial-jurídica contra os mais diferentes agentes terapêuticos populares e suas respectivas atuações curativas. Reunidos sob os rótulos de praticantes ilegais da medicina, de charlatães ou de curandeiros, estão os velhos pajés-caboclos remanescentes de grupos indígenas desagregados; santos milagreiros, beatos, benzedeiras, raizeiros, curadores de cobras, negros rezadores e curadores, todos integrados aos quadros do catolicismo popular. Temos também os adeptos do espiritismo como alvos de perseguição, uma vez que se discutia a legitimidade do espiritismo enquanto religião a ser reconhecida pelo Estado." (Direito e antropologia: uma história de encontros e desencontros: julgamentos de curandeirismo e charlatanismo (Brasil - 1900/1990), cit., p. 142).
} 
práticas terapêuticas realizadas na umbanda. Neste ponto, deslegitimando a interferência estatal, ganha destaque também o princípio constitucional da liberdade de manifestação religiosa, concretizado no direito fundamental à liberdade de consciência e de crença e ao livre exercício dos cultos religiosos $\left(\operatorname{art} .5^{\circ}, \mathrm{VI}\right)^{272}$.

Por esses motivos, conclui-se que os crimes do art.283 e 284 do Código Penal, da forma como previstos, parecem não terem sido recepcionados pela Constituição de 1988.

\subsection{Uso e tráfico de drogas}

A criminalização do uso e do tráfico de drogas, da forma como se coloca hoje, insere-se no contexto de uma verdadeira guerra declarada contra as drogas. Costuma-se a apontar como principal precursor e protagonista dessa batalha os Estados Unidos da América, os quais, motivados por diversos interesses, inclusive morais e religiosos ${ }^{273}$, além de econômicos, desde o início do século XX, elegeram os usuários e traficantes de drogas como um grande mal a ser combatido, como inimigo número um do Estado, criando-se uma verdadeira "guerra" 274 , tendência esta que foi amplamente difundida no plano internacional ${ }^{275}$, chegando também ao Brasil $^{276}$.

\footnotetext{
${ }^{272}$ Sobre o tema, fundamental a leitura da peça de habeas copus impetrado por Antônio Evaristo de Moraes Filho em favor do bispo Edir Macedo, o qual havia sido denunciado pelos crimes de estelionato, charlatanismo e curandeirismo, simplesmente por exercer seu Ministério religioso no âmbito da Igreja Universal do Reino de Deus. Cf. MORAES FILHO, Antonio Evaristo de; LAVIGNE, Arthur; RIBEIRO, Paulo Freitas. Crime de curandeirismo e liberdade de culto (trabalho forense). Revista Brasileira de Ciências Criminais, São Paulo, v. 1, n. 2, p. 255-277, abr./jun. 1993.

${ }^{273}$ BECHARA, Ana Elisa Liberatore Silva. Da teoria do bem jurídico como critério de legitimidade do direito penal, cit., p. 341. Juarez Tavares destaca que "a comunidade vê na droga, por influência da mídia, um símbolo de demonização do comportamento humano”. (Teoria do injusto penal, cit., p. 294).

${ }^{274}$ Janaína Conceição Paschoal lembra que "sob a desculpa de que estamos em guerra contra as drogas e de que, na guerra, tudo vale - aumentar pena, endurecer regimes, reduzir direitos -, paulatinamente, vão-se deixando de lado garantias duramente conquistadas." (A importância do encontro sobre drogas: aspectos penais e criminológicos. In: REALE JÚNIOR, Miguel (Coord.). Drogas: aspectos penais e criminológicos. Rio de Janeiro: Forense, 2005. p. 5).

${ }^{275} \mathrm{Cf}$. histórico em BOITEUX, Luciana; WIECKO, Ela; BATISTA; Vanessa; PRADO, Geraldo (Coords.). Tráfico de drogas e Constituição. Brasília-DF: Ministério da Justiça, 2009. p. 24-36.

${ }^{276}$ REALE JÚNIOR, Miguel. Quebrando o tabu. O Estado de S. Paulo, São Paulo, 02 jul. 2011. Cf., também, EDITORIAL: Drogas: guerra ou paz? Boletim IBCCRIM, São Paulo, v. 16, n. 196, p. 1, mar. 2009. Acerca do histórico da legislação penal sobre drogas no Brasil até a revogada Lei $n^{\circ}$ 6.368/76, cf. SILVEIRA, Renato de Mello Jorge. Direito penal supra-individual. São Paulo: Ed. Revista dos Tribunais, 2003. p. 127-128. Também para uma perspectiva histórica brasiliera, cf. FRAGOSO, Heleno Cláudio. Aspectos legais da toxicomania. Revista Brasileira de Criminologia e Direito Penal, Rio de Janeiro, v. 2, n. 8, p. 85-100, jan./mar. 1965.
} 
Prescindindo-se de uma análise histórica detalhada, e do estudo também sob uma perspectiva criminológica e político-criminal ${ }^{277}$, o que demandaria longas páginas que poderiam desviar do objetivo perseguido neste trabalho, busca-se aqui, sem menosprezar a complexidade da temática, analisar tão somente o atual cenário legislativo brasileiro no que se refere aos crimes de uso e tráfico de drogas, evidentemente, sob uma perspectiva normativa constitucional-democrática.

Iniciando pelo crime de uso de drogas, verifica-se que a atual lei de regência brasileira - Lei no 11.343/2006 - criminaliza a conduta de "quem adquirir, guardar, tiver em depósito, transportar ou trouxer consigo, para consumo pessoal, drogas sem autorização ou em desacordo com determinação legal ou regulamentar" (art.28). O único objetivo, por evidência, é criminalizar o ato de consumir drogas, sendo que todos os demais verbos do tipo são agregados apenas para facilitar o flagrante e a colheita de provas.

O fundamento da incriminação parece ser bem claro: o Estado, por meio de uma presunção absoluta revelada em uma simples Portaria do Ministério da Saúde, considera o consumo de certas drogas um mal ${ }^{278}$, e, mais uma vez, vale-se de seu instrumento mais gravoso para proteger potenciais consumidores, ignorando a vontade individual. Mesmo na hipótese de se aceitar o argumento de que o consumo de drogas seja sempre lesivo à saúde, não há como deixar de reconhecer que se trata da mais evidente criminalização da autolesão, de exercício do paternalismo estatal direto por meio do Direito Penal ${ }^{279}$.

\footnotetext{
${ }^{277}$ Para tanto, cf. CARVALHO, Salo de. A política criminal de drogas no Brasil. 5. ed. Rio de Janeiro: Lumen Juris, 2010. REALE JÚNIOR, Miguel (Coord.). Drogas: aspectos penais e criminológicos. Rio de Janeiro: Forense, 2005. BOITEUX, Luciana. Breves considerações sobre a política de drogas brasileira atual e as possibilidades de descriminalização. Boletim IBCCRIM, São Paulo, ano 18, n. 217, p. 16, dez. 2010. SOUZA, Luciano Anderson de. Punição criminal ao porte de entorpecentes para uso próprio e irracionalismo repressivo: uma ainda necessária reflexão. Revista Brasileira de Ciências Criminais, São Paulo, v. 19, n. 88, p. 167-186, jan./fev. 2011. Cf., ainda, edição especial de Boletim IBCCRIM dedicada ao tema das drogas, publicada em outubro de 2012. ANÁLISE da constitucionalidade sobre a incriminação do porte de drogas para consumo pessoal. Boletim IBCCRIM, São Paulo, ano 20, ed. esp., out. 2012. Disponível em: <http://www.ibccrim.org.br/site/boletim/pdfs/Boletim239A.pdf>.

${ }^{278}$ Muitos argumentos poderiam ser utilizados já para questionar tal assertiva. Será que o consumo de drogas é sempre lesivo à saúde? Qual a influência de argumentos morais e religiosos para se chegar nesta certeza absoluta? E o caso daquelas pessoas, p. ex., que vivem infelizes e deprimidas sem a droga e extremantes felizes e sem depressão com as drogas? E o que dizer daqueles produtos também considerados extremamente danosos à saúde (álcool, tabaco etc), mas que são de consumo lícito e até fomentado pelo Estado? Sobre as contradições da política de criminalização no campo das drogas, cf. MUÑOZ CONDE, Francisco; AUNION ACOSTA, Bella. Drogas y derecho penal. Eguzkilore: Cuaderno del Instituto Vasco de Criminología, San Sebastian, n. 5, p. 147-157, dez. 1991. Criticando a presunção absoluta de perigo ou dano extraída de mera afirmação oficial, cf. SILVEIRA, Renato de Mello Jorge. Direito penal supraindividual, cit., p. 128 e seg.

${ }^{279}$ ESTELLITA, Heloisa. op. cit., p. 337-338.
} 
Como visto, no Estado Democrático de Direito, tolerante perante todas as formas de vida que não impliquem em dano direto a terceiro, o princípio constitucional da autorresponsabilidade assegura a cada indivíduo o direito de fazer o que bem entender com a sua própria saúde, exercendo a sua plena autonomia, desenvolvendo livremente a sua personalidade. Nesta linha, pode-se afirmar que, ao menos perante o poder punitivo estatal, cada pessoa é livre, para decidir, por exemplo, se deseja ingerir 3 litros de CocaCola por dia, comer 5 sanduíches da rede Mcdonalds no café da manhã todos os dias, saltar de paraquedas 3 vezes por semana, escalar o Monte Everest 1 vez ao ano, tomar 10 garrafas de cervejas por hora, ou fumar um único cigarro de maconha. Todos esses atos, isoladamente, dizem respeito apenas ao próprio individuo, à sua própria intimidade, não sendo possível vislumbrar qualquer dano direto a terceiro, o que torna ilegítima a intervenção penal do Estado ${ }^{280}$.

Novamente, com a criminalização do consumo de drogas, o Estado tenta impor um padrão de vida que considera "bom" ou "saudável”, seguindo um modelo moral de abstinência a ser imposto a todos, independentemente das convicções pessoais de cada um, em franca contradição ao modelo pluralista propugnado pelo Estado Democrático de Direito ${ }^{281}$.

Diante desse cenário, na tentativa quase desesperada de conferir legitimidade à criminalização, parte-se para a busca de um bem jurídico supra-individual ou coletivo supostamente passível de lesão por meio da conduta de consumir drogas. Assim, argumenta-se, geralmente sem qualquer reflexão, que o dano aqui não seria somente à saúde indivíduo, mas alcançaria uma aventada "saúde pública". ${ }^{282}$ Aduz-

\footnotetext{
${ }^{280}$ De forma semelhante, Bernd Shunemann afirma que, na posse de tóxicos, "o consumidor individual se auto-coloca em perigo de modo livre e responsável, não criando risco de maior relevância para o direito penal do que ações como o abuso de álcool, o consumo de carne extremamente gordurosa ou a prática de bungee jumping." (O direito penal é a ultima ratio da proteção de bens jurídicos: sobre os limites invioláveis do direito penal em um estado de direito liberal, cit., p. 26).

281، A pretensão de tutela penal da saúde ou integridade do agente contra a sua própria vontade ou interesse configuraria paternalismo penal intolerável no âmbito de um Estado Democrático que toma os cidadãos como autorresponsáveis e capazes de eleger os caminhos do próprio desenvolvimento pessoal, por uma perspectiva pluralista. Bem por isso, o modelo moral de abstinência não pode ser juridicamente imposto como concepção correta de vida." (BECHARA, Ana Elisa Liberatore Silva. Da teoria do bem jurídico como critério de legitimidade do direito penal, cit., p. 342). "A Justiça Criminal não tem condições nem é legitimada para impor uma determinada moral ou um comportamento que não coloquem em risco outras pessoas" (BOITEUX, Luciana. Breves considerações sobre a política de drogas brasileira atual e as possibilidades de descriminalização, cit.). Denominando de "crime sem vítima" o porte de drogas para uso próprio, cf. REALE JÚNIOR, Miguel. Instituições de direito penal, cit., p. 25.

${ }^{282}$ Assim, p. ex., GOMES, Luiz Flávio et. al. Lei de drogas comentada. 2. ed. São Paulo: Ed. Revista dos Tribunais, 2007. p. 150. JESUS, Damásio de. Lei antidrogas anotada. 9. ed. São Paulo: Saraiva, 2009. p. 48. MARCÃO, Renato. Tóxicos. 4. ed. São Paulo: Saraiva, 2007. p. 73. NUCCI, Guilherme de Souza. Leis
} 
se, nesse sentido, que os efeitos da disseminação do uso de drogas seriam maléficos para a sociedade em geral, gerando altos custos para o sistema público de saúde e, ainda, propiciando um aumento no número de cometimento de crimes.

Primeiramente, importa dizer que a própria tentativa de construção de um bem jurídico "saúde pública" já se mostra problemática. Diferentemente de bens como a Administração Pública ou o meio ambiente, que se revestem do caráter da indivisibilidade, sendo gozados por todos, ao mesmo tempo, em sua totalidade, a saúde pública parece nada mais ser do que a soma das saúdes de cada indivíduo, sendo, pois, facilmente divisível, assim como cada um possui a sua vida, a sua honra ou o seu patrimônio $^{283}$. Assim, trata-se, aparentemente, da invenção de um falso bem jurídico coletivo, com o escopo de legitimar a intervenção penal, muitas vezes de forma demasiadamente antecipada, com o uso frequente de tipos de perigo abstrato, eventualmente difarçando o caráter paternalista da incriminação, e, ainda, visando justificar a cominação de penas desproporcionais ${ }^{284}$.

Em segundo lugar, mesmo na hipótese de se aceitar a saúde pública como um bem jurídico penal possível no Direito Penal, certamente é ir longe demais imaginar que o consumo individual de drogas afete a saúde de terceiros, afigurando-se como uma conduta que, nitidamente, restringe-se ao âmbito da intimidade do próprio usuário ${ }^{285}$.

penais e processuais penais comentadas, cit., p. 304. Este último afirma que "não se pune o porte de droga, para uso próprio, em função da proteção à saúde do agente (a autolesão não é punida, como regra, pelo ordenamento jurídico-penal), mas em razão do mal potencial que pode gerar à coletividade."

${ }^{283}$ Ressaltando o caráter da "não distributividade" dos bens jurídicos coletivos, isto é, a impossibilidade de divisão entre possíveis titulares individuais, cf. HEFENDEHL, Roland. O bem jurídico como pedra angular da norma penal. In: GRECO, Luís; TÓRTIMA, Fernanda Lara (Orgs.). O bem jurídico como limitação ao poder estatal de incriminar? Rio de Janeiro: Lumen Juris, 2011. p. 57-75. Id. Uma teoria social do bem jurídico. Revista Brasileira de Ciências Criminais, São Paulo, v. 18, n. 87, p. 103-120, nov./dez. 2010. Id. (Ed.). La teoría del bien jurídico: fundamento de legitimación del derecho penal o juego de abalorios dogmático?, cit., p. 182 e seg.

${ }^{284}$ GRECO, Luís. Princípio da ofensividade e crimes de perigo abstrato: uma introdução ao debate sobre o bem jurídico e as estruturas do delito. Revista Brasileira de Ciências Criminais, São Paulo, v. 12, n. 49, p. 89-147, jul./ago. 2004. Também criticando o apontado bem jurídico, cf. BECHARA, Ana Elisa Liberatore Silva. Da teoria do bem jurídico como critério de legitimidade do direito penal, cit., p. 343 e seg. ROXIN, Claus. Estudos de direito penal, cit., p. 51. DÍEZ RIPOLLÉS, José Luis. Alternativas a la actual legislación sobre drogas. Cuadernos de Política Criminal, Madrid, n. 46, p. 90, 1992. SCHÜNEMANN, Bernd. op. cit., p. 9-37. "Estar-se-ia a tutelar a saúde das pessoas ou, de forma contrária, a antecipar a tutela de perigosa forma, prevendo, quase que unicamente, uma tutela da segurança a ser tida e travestida como saúde pública?" (SILVEIRA. Renato de Mello Jorge. Dos crimes contra a dignidade sexual, cit., p. 132).

285، A posse de drogas para uso pessoal é conduta que, se situando na esfera individual, não atinge a terceiros, assim se inserindo no campo da intimidade e da vida privada, em cujo âmbito é vedado ao Estado - e, portanto, ao Direito - penetrar. Assim como não se pode criminalizar e punir - como, de fato, não se pune a tentativa de suicídio e a autolesão, não se pode criminalizar e punir a posse de drogas para uso pessoal, que, menos danosa do que aquelas, pode encerrar, no máximo, um simples perigo de autolesão". (KARAM, Maria Lúcia. Drogas: a irracionalidade da criminalização. Boletim IBCCRIM, São Paulo, n.45, p. 9-10, ago. 
Além disso, ainda que sejam tidos como verdadeiros os questionáveis altos custos gerados ao sistema público de saúde e o suposto aumento no número de cometimento de delitos, estes não se mostram argumentos idôneos a fundamentar uma incriminação, pois guardariam relação apenas indireta, remota e abstrata, além de futura e incerta, com a conduta tipificada, carecendo, até mesmo, de mínima racionalidade ${ }^{286}$. Se fosse válido o primeiro argumento, também seria justificável, por exemplo, a criminalização do sedentarismo, do exercício de profissão estressante, do uso de tabaco e de álcool, da ingestão de alimentos gordurosos, do ato de ter muitos filhos, e de muitos outros que apresentam relação remota com o sistema público de saúde. O segundo argumento, como exposto quando da análise dos jogos de azar e do jogo do bicho, mão merece melhor sorte. A repressão penal a determinada conduta somente se legitima se esta, por si mesma, é ofensiva a algum bem jurídico fundamental. A relação remota, imaginária, futura e incerta, com outros delitos não tem o condão de justificar uma incriminação. Parece haver, também, uma forte carga moral preconceituosa, ao relacionar obrigatoriamente o consumidor de drogas a autores de furtos, roubos e outros delitos. Isso sem falar na contradição lógica de se tentar legitimar uma proibição com as consequências do próprio ato de proibir $^{287}$. Seriam estes legítimos argumentos a mitigar o princípio da autorresponsabilidade? A resposta só pode ser negativa, concluindo-se pela inconstitucionalidade do crime previsto no art.28 da Lei $\mathrm{n}^{\mathrm{o}} 11.343 / 2006^{288}$.

1996). Em sentido contrário: “A razão jurídica da punição daquele que adquire, guarda, tem em depósito ou traz consigo para uso próprio é o perigo social que sua conduta representa. Mesmo o viciado, quando traz consigo a droga, antes de consumi-la, coloca a saúde pública em perigo, porque é fator decisivo na difusão dos tóxicos. O toxicômano normalmente acaba traficando, a fim de obter dinheiro para a aquisição da droga, além de psicologicamente estar predisposto a levar outros ao vício, para que compartilhem ou de seu paraíso artificial ou de seu inferno." (GRECO FILHO, Vicente; RASSI, João Daniel. Lei de drogas anotada: Lei n. 11.343/2006. 2. ed. São Paulo: Saraiva. 2008. p. 46).

${ }^{286}$ Em sentido semelhante, BECHARA, Ana Elisa Liberatore Silva. Da teoria do bem jurídico como critério de legitimidade do direito penal, cit., p. 344-346.

${ }^{287}$ Exatamente nessa linha, a lição de Maria Lúcia Karam: “Ao tornar ilegais determinados bens e serviços, como ocorre também em relação ao jogo, o sistema penal funciona como o real criador da criminalidade e da violência. Ao contrário do que se costuma propagar, não são as drogas em si que geram criminalidade e violência, mas é o próprio fato da ilegalidade que produz e insere no mercado empresas criminosas - mais ou menos organizadas - simultaneamente trazendo, além da corrupção, a violência como outro dos subprodutos necessários das atividades econômicas assim desenvolvidas, com isso provocando consequências muito mais graves do que eventuais malefícios causados pela natureza daquelas mercadorias tornadas ilegais." (Drogas: a irracionalidade da criminalização, cit.). Sinalizando no mesmo sentido, ROXIN, Claus. Estudos de direito penal, cit., p. 46.

288، A punição do uso de tóxicos, conduta que provoca meras auto-lesões e não ultrapassa o limite de privacidade do envolvido, viola frontalmente a Constituição, mais precisamente os arts. $1^{\circ}$, III (dignidade humana), $5^{\circ}$, caput (liberdade), $5^{\circ}$, VI e VII (liberdade de consciência), e $5^{\circ}$, X (intimidade, vida privada). Um Estado de Direito que mereça este nome justamente abdicou de uma das prerrogativas do Estado Autoritário: a de arvorar-se em juiz do bem-estar dos cidadãos. Logo, um direito penal que respeite a liberdade do cidadão de escolher o que é melhor para si, que o trate como um adulto responsável pelos seus 
Passando à análise do tipo de tráfico de drogas, verifica-se a criminalização da conduta de "importar, exportar, remeter, preparar, produzir, fabricar, adquirir, vender, expor à venda, oferecer, ter em depósito, transportar, trazer consigo, guardar, prescrever, ministrar, entregar a consumo ou fornecer drogas, ainda que gratuitamente, sem autorização ou em desacordo com determinação legal ou regulamentar" (art.33, caput, da Lei no 11.343/2006). Mais uma vez, não obstante a multiplicidade de verbos, o objetivo é único: criminalizar a produção e movimentação da droga, ou seja, impedir que ela chegue até o usuário.

Ao contrário do crime de uso de drogas, que, finalmente, vem tendo a sua repressão penal arrefecida nos cenários internacional e brasileiro, a sensação que se tem é a de que o traficante de drogas está sendo, cada vez mais, elevado à condição de inimigo público número um do Estado. Pode-se afirmar que, no imaginário popular, trabalhado diariamente pela mídia, provavelmente o traficante fique atrás até mesmo do homicida em nível de "maldade", sendo ambas as figuras frequentemente confundidas.

Vale observar, todavia, que, de forma intrigante, este pensamento não é privilégio de quem não possui conhecimento técnico-cientifico em Direito. A enorme maioria da doutrina e da jurisprudência penal, com base em inúmeros argumentos de toda espécie, elabora, aceita, e fomenta a tese de que o tráfico de drogas é um grande mal a ser combatido por meio da forte repressão penal, tema transformado em verdadeiro tabu. Ademais, não há como ignorar que esta ideia foi absorvida pela própria Constituição Federal de 1988, a qual, em seu art.5 ${ }^{\circ}$, XLIII $^{289}$, atribui um regime jurídico especialmente gravoso ao crime de tráfico de drogas. Seguindo esta linha, o legislador nacional acabou por cominar uma pena de reclusão de 5 a 15 anos de prisão ao traficante, extremamente alta quando comparada aos demais delitos do sistema punitivo brasileiro. Será mesmo o crime de tráfico de drogas este grande "mal" da humanidade?

próprios atos, não pode condená-lo por ter ele escolhido um caminho diferente do que se costuma seguir." (GRECO, Luís. Tipos de autor e lei de tóxicos ou interpretando democraticamente uma lei autoritária. Revista Brasileira de Ciências Criminais, São Paulo, v. 11, n. 43, p. 235-236, abr./jun. 2003). No ano de 2009, o Tribunal Constitucional Argentino, utilizando como um dos argumentos principais a ideia de não ser legítima a intervenção estatal na esfera privada do indivíduo, por força do art.19 da Constituição argentina (vide nota 152 , supra), declarou que o tipo penal de posse de droga para consumo próprio é inconstitucional. Cf., a esse respeito, GRECO, Luís. Posse de droga, privacidade, autonomia: reflexões a partir da decisão do Tribunal Constitucional argentino sobre a inconstitucionalidade do tipo penal de posse de droga com a finalidade de próprio consumo. Revista Brasileira de Ciências Criminais, São Paulo, v. 18, n. 87, p. 84-102, nov./dez. 2010.

289،Art. $5^{\circ}$, XLIII - a lei considerará crimes inafiançáveis e insuscetíveis de graça ou anistia a prática da tortura, o tráfico ilícito de entorpecentes e drogas afins, o terrorismo e os definidos como crimes hediondos, por eles respondendo os mandantes, os executores e os que, podendo evitá-los, se omitirem". 
Para o tipo de análise que se pretende no presente trabalho, busca-se, novamente, o fundamento da incriminação, que parece não diferir muito do relativo ao uso de drogas: o Estado considera o consumo de certas drogas um mal, e, por esse motivo, busca impedir que ela alcance potenciais usuários, protegendo tais indivíduos mesmo contra a sua vontade. Trata-se, pois, da criminalização de uma participação em uma autolesão, reveladora de um paternalismo indireto, punindo-se aquele que, de alguma forma, contribui para que o indivíduo faça uso de droga e, assim, eventualmente, lesione a sua própria saúde ${ }^{290}$. Em uma visão tecnicamente rigorosa, considerando a incriminação do próprio uso de drogas, a conduta de tráfico prescindiria de qualquer previsão legal autônoma, tendo em vista a possibilidade de se recorrer à norma de extensão do art.29 do Código Penal ${ }^{291}$. Há, ainda, quem sustente que o crime de tráfico de drogas seja verdadeiro tipo de autor, buscando-se, de forma autoritária, punir apenas a figura do traficante, revelando uma espécie de desvalor da personalidade ${ }^{292}$.

Diante desse cenário, parte-se, uma vez mais, agora com força ainda maior, para a tentativa de encontrar um bem jurídico supra-individual que possa legitimar a incriminação. Também aqui a lesão ou perigo à saúde pública ${ }^{293}$, os altos custos gerados

\footnotetext{
290“'Considerando que o uso de drogas é uma autolesão, as condutas previstas como tráfico seriam formas de participação no hábito do usuário. Todas as ações descritas nos artigos referentes ao tráfico (em especial os artigos 33 e 34) são meios para o usuário, destinatário final, consumir a droga. Ninguém pratica o tráfico se não houver quem pague pelo produto e, normalmente, o último da cadeia é o usuário. Sendo assim, podemos perguntar: seria legítimo criminalizar condutas que são meios de participação em autolesões? A criminalização do tráfico não seria um instrumento estatal para interferir na escolha do usuário, pois dificultaria seu acesso à droga?" (MARTINELLI, João Paulo Orsini. Paternalismo na lei de drogas. Revista Liberdades, São Paulo, n. 2, p. 13-24, set./dez. 2009) Acenando para uma "interpretação teleológica restritiva do tipo" de tráfico de drogas, afastando a atuação paternalista contrária à vontade do indivíduo que recebe a droga, cf. GRECO, Luís. Princípio da ofensividade e crimes de perigo abstrato: uma introdução ao debate sobre o bem jurídico e as estruturas do delito, cit., p. 114.

${ }^{291 ، A A r t . ~} 29$ - Quem, de qualquer modo, concorre para o crime incide nas penas a este cominadas, na medida de sua culpabilidade."

${ }^{292}$ Assim: GRECO, Luís. Tipos de autor e lei de tóxicos ou interpretando democraticamente uma lei autoritária, cit.

${ }^{293}$ Entendendo ser a "saúde pública" o bem jurídico, sem deixar de revelar, mesmo que disfarçadamente, o fundamento paternalista: "Não se permite que determinados entorpecentes circulem em sociedade porque seus danos, ao longo do tempo, já foram comprovados, não somente por médicos, cientistas, especialistas da área de saúde pública em geral, como também por fatos concretos passados. (...) Em conclusão, o crime de tráfico ilícito de entorpecentes é infração penal de perigo, representando a probabilidade de dano à saúde de pessoas, mas não se exige a produção de tal resultado para a sua consumação." (NUCCI, Guilherme de Souza. Leis penais e processuais penais comentadas, cit., p. 315). "O bem jurídico protegido é a saúde pública (tutela imediata) e a saúde individual de pessoas que integram a sociedade (tutela mediata). A saúde pública é um bem jurídico supra-individual que deve sempre ter como referência última os bem jurídicos pessoais." (GOMES, Luiz Flávio et. al. Lei de drogas comentada, cit., p. 178). "O bem jurídico protegido pelo delito é a saúde pública. A deterioração causada pela droga não se limita àquele que a ingere, mas põe em risco a própria integridade social. O tráfico de entorpecentes pode ter, até, conotações políticas, mas basicamente o que a lei visa evitar é o dano causado à saúde pelo uso de drogas." (GRECO FILHO, Vicente; RASSI, João Daniel. op. cit., p. 83). Neste mesmo sentido, JESUS, Damásio de. op. cit., p. 79-82. MARCÃO, Renato. op. cit., p. 187.
} 
ao sistema público de saúde e a relação com outros delitos, aparecem como argumentos principais. Salienta-se que a circulação de drogas causaria um grande mal a toda a sociedade, propiciando a manutenção de viciados, os quais, necessariamente, acabam sobrecarregando o aparato do sistema público de saúde. Ressalta-se que o tráfico de drogas estaria diretamente ligado ao crime organizado e ao cometimento de inúmeros delitos, tais como homicídios, roubos, extorsões, formação de quadrilha, lavagem de dinheiro e outros.

Primeiramente, ainda que se aceite a problemática colocação da "saúde pública" como legítimo bem jurídico supra-individual ou coletivo, parece difícil imaginar que a conduta de fazer chegar a droga a determinado indivíduo ou grupo de indivíduos possa afetar diretamente a saúde de terceiros não envolvidos na relação ${ }^{294}$. Quem vende droga a uma pessoa está, no máximo, contribuindo para que aquela mesma pessoa, ao fazer uso do produto, se autolesione. ${ }^{295}$ De que forma isso afetaria a saúde de toda a sociedade ou de um número indeterminado de pessoas? Vale lembrar, novamente, que danos ou perigos de danos indiretos, remotos, abstratos, futuros e incertos, ou imaginários, não têm o condão de legitimar uma incriminação ${ }^{296}$.

Os argumentos relativos aos supostos custos do sistema público de saúde e a relação com outros delitos apresentam os mesmos graves problemas de legitimidade já esposados acima, quando da análise do crime de uso de drogas. Importante mencionar, contudo, que a tese da relação com graves delitos ganha ainda mais destaque quando se trata de tráfico ${ }^{297}$. Além do fato de que a simples ligação com condutas lesivas a bem

\footnotetext{
${ }^{294}$ A escolha desse provável falso bem jurídico coletivo conduz a distorções absurdas. Com base no argumento da "saúde pública", vender um cigarro de maconha para alguém ou simplesmente armazenar alguns pacotes de cocaína para venda (art.33 da Lei no 11.343/2006) é muito mais grave, p. ex., do que dar um soco em alguém (art.21 da LCP ou 129, caput, do CP) ou, até mesmo, cegar ou amputar o braço de uma pessoa (art.129, $\S 2^{\circ}$, III, do CP). Em outras palavras, causar dolosa e diretamente uma lesão a um indivíduo, contrariamente à sua vontade, é muito mais grave do que contribuir para que este mesmo indivíduo se autolesione voluntaria e conscientemente. Sobre o tema, cf. GRECO, Luís. Princípio da ofensividade e crimes de perigo abstrato: uma introdução ao debate sobre o bem jurídico e as estruturas do delito, cit.

${ }^{295}$ Claus Roxin, embora reconheça que todo o Direito Penal de drogas esteja ligado a uma autolesão consciente ou a sua possibilitação e promoção, acaba por defender que o trato com "drogas pesadas deva ser punido", pois "a dependência por elas provocada destrói, em regra, contra a vontade do consumidor, a autonomia de sua personalidade, algo que deve o direito penal justamente proteger, e sobrecarrega os que pagam impostos com os altos custos da terapia”. (Estudos de direito penal, cit., p. 45).

${ }^{296}$ Luís Greco lembra que punir o "traficante" "por mortes que só remotamente pode vir a causar seria o mesmo que punir os fabricantes de carros pelos homicídios a que o tráfico rodado dá causa." (Tipos de autor e lei de tóxicos ou interpretando democraticamente uma lei autoritária, cit., p. 234). Também contrário a "uma tal responsabilidade por possíveis consequências lesivas futuras", invocando o "princípio da responsabilidade pessoal própria", cf. HIRSCH, Andrew von. op. cit., p. 25-26.

${ }^{297}$ Exigência, diga-se de passagem, que não consta do tipo dos artigos 28 ou. 33 da lei no 11.343/2006.
} 
jurídicos jamais poder justificar uma incriminação, como já visto, a contradição lógica aqui se torna ainda mais evidente. Mesmo aceitando-se a presunção de que esta relação realmente ocorra, não é preciso um raciocínio muito apurado para perceber que o traficante somente se envolve - de modo diferenciado - com outros delitos devido à ilicitude de sua atividade principal, qual seja, o tráfico de drogas ${ }^{298}$. Justificar uma proibição com as consequências do próprio ato de proibir revela uma contradição lógica inaceitável ${ }^{299}$.

Diante de tudo isso, não há como deixar de reconhecer que a criminalização do tráfico de drogas também indica uma violação ao princípio da autorresponsabilidade, vez que revela a tentativa de imposição de um padrão de conduta longe das drogas, impedindo ou dificultando a sua chegada ao usuário, e, assim, em última análise, protegendo este indivíduo potencial consumidor contra a sua própria vontade ${ }^{300}$, considerando-o incapaz de fazer suas próprias escolhas. Importa consignar, todavia, que o reconhecimento ou não da inconstitucionalidade deste delito demandaria um estudo mais aprofundado, em trabalho à parte, tendo em vista o dispositivo do art. $5^{\circ}$, XLIII, da Constituição Federal ${ }^{301}$ e o possível conflito entre normas constitucionais.

\footnotetext{
${ }^{298}$ Incluindo o impedimento de muitos homicídios e o desmantelamento de grande parte do crime organizado entre as possíveis consequências do "fim da guerra", com a descriminalização do tráfico, cf. SÁ, Alvino Augusto de. Sonhando com o "fim do tráfico" de entorpecentes. Boletim IBCCRIM, São Paulo, ano 18, n. 211, p. 4-6, jun., 2010.

${ }^{299}$ Defendendo a descriminalização do tráfico de drogas, por razões diversas: KARAM, Maria Lúcia. Drogas: a irracionalidade da criminalização, cit. Id. A Lei n. 11.343/06 e os repetidos danos do proibicionismo. Boletim IBCCRIM, São Paulo, v. 14, n. 167, p. 6-7, out. 2006. MUÑOZ CONDE, Francisco; AUNION ACOSTA, Bella.ob.cit. DÍEZ RIPOLLÉS, José Luis. Alternativas a la actual legislación sobre drogas, cit., p. 73-115. Também sugerindo alternativas ao tratamento penal das drogas, cf. DIAS NETO, Theodomiro. O direito à vida e o direito penal. Folha de S. Paulo, São Paulo, p. A3, 20 jan. 2005.

${ }^{300}$ Ressalte-se que o tipo penal não exige que a vontade do consumidor esteja com alguma espécie de defeito. Em sentido contrário, Claus Roxin assevera que "la punibilidad de la venta de drogas etc. se justifica por la incontrolabilidad, que de lo contrario se produciría, de su difusión y de su peligro para consumidores no responsables, sobre todo también para los jóvenes menores de edad”. (Derecho penal: parte general, cit., p. 529).

301،Art. $5^{\circ}$ - XLIII - a lei considerará crimes inafiançáveis e insuscetíveis de graça ou anistia a prática da tortura , o tráfico ilícito de entorpecentes e drogas afins, o terrorismo e os definidos como crimes hediondos, por eles respondendo os mandantes, os executores e os que, podendo evitá-los, se omitirem."
} 


\subsection{Comércio de tecidos, órgãos ou partes do corpo humano}

A Lei n ${ }^{\circ}$ 9.434/1997 prevê, em seu art.15, o crime de comércio de tecidos, órgãos ou partes do corpo humano ${ }^{302}$. Pune-se, com uma elevada pena de reclusão de 3 a 8 anos, além de multa, tanto aquele que compra quanto aquele que vende referido material ${ }^{303}$.

Considerando que todos os participantes do comércio são indivíduos adultos e plenamente responsáveis, pergunta-se: qual o bem jurídico passível de lesão com a prática deste delito?

Para responder tal pergunta, parte-se, novamente, para uma tentativa quase desesperada de encontrar alguma base de legitimação para a intervenção penal.

Aponta-se, por exemplo, uma suposta violação à dignidade humana, mais precisamente da dignidade da pessoa que vende uma parte de seu próprio corpo. Como já demonstrado no âmbito do presente trabalho a dignidade humana não pode servir de única referência direta para a legitimação da intervenção penal, funcionando como verdadeiro "coringa" argumentativo, deixando quase sem limites o alcance do pode punitivo. Além do mais, como também já ressaltado, no atual modelo de Estado, a dignidade humana deve, principalmente, relacionar-se à capacidade de autonomia, de viver segundo seu próprio plano de vida, de não servir como instrumento a finalidade alheias, o que não se coaduna com a ideia de tolhimento da liberdade de dispor do próprio corpo. Por fim, ainda que se admitisse tal problemática ofensa à dignidade humana, seria necessário debater a possibilidade ou não de sua livre disposição ${ }^{304}$.

\footnotetext{
302،Art. 15. Comprar ou vender tecidos, órgãos ou partes do corpo humano: Pena - reclusão, de três a oito anos, e multa, de 200 a 360 dias-multa. Parágrafo único. Incorre na mesma pena quem promove, intermedeia, facilita ou aufere qualquer vantagem com a transação".

${ }^{303}$ No cenário jurídico brasileiro, praticar dolosamente, sem o consentimento da vítima, a conduta de furar os olhos de uma pessoa, cegando-a completamente (CP, art.129, §2 $2^{\circ}$, pena: reclusão de 2 a 8 anos), mostra-se menos grave do que comprar um órgão dessa mesma pessoa que deseja voluntariamente vendê-lo, ainda que seja para retirada post-mortem.

${ }^{304}$ “O direito penal só tem por finalidade evitar lesões a outros. Impedir que as pessoas se despojem da própria dignidade não é problema do direito penal. Mesmo se se quisesse, p. ex., considerar o suicídio um desprezo à própria dignidade - o que eu não julgo correto -, este argumento não poderia ser trazido para fundamentar a punibilidade do suicídio tentado." (ROXIN, Claus. Estudos de direito penal, cit., p. 40).
} 
Há, ainda, quem sustente que a vida seria o bem jurídico passível de lesão com a prática do crime ora em análise ${ }^{305}$. Ora, quer dizer que toda venda de órgão, tecido ou parte do corpo humano implica em sacrifício da vida? ${ }^{306}$ Aquele que vende cachos de seu belo cabelo ou até mesmo um de seus rins assina um contrato de morte? E quando a venda ocorre para retirada post-mortem? Novamente, ainda que se admitisse tal raciocínio, haveria a necessidade de se adentrar na discussão acerca da disponibilidade da vida.

Diante desse cenário, verifica-se tratar-se de mais um crime sem vítima, expressão do paternalismo estatal ${ }^{307}$. O Estado considera "ruim" a existência do comércio de órgãos, tecidos ou partes do corpo humano, e, simplesmente por isso, opta por criminalizar a conduta, estabelecendo um padrão de atuação afastado desse tipo de atividade. A se considerar que a intenção do legislador é proteger o titular do órgão comercializado - mesmo não se sabendo exatamente de que se está protegendo evidencia-se um duplo paternalismo, direto e indireto, uma vez que a repressão penal incide sobre quem vende e, também, sobre quem compra o material ${ }^{308}$.

Por esses motivos, pode-se concluir que a atuação do poder punitivo penal sobre as condutas de vender ou comprar órgãos, tecidos ou parte do corpo, parece não encontrar base de legitimidade no atual modelo de Estado brasileiro.

Vale pontuar, para finalizar, que não se ignora a existência de uma vedação constitucional ao comércio de órgãos, tecidos ou substâncias humanas, prevista no art.199, $\S 4^{\text {o309}}$, sendo certo, todavia, que esta não possui qualquer natureza penal. Admitese, portanto, que, fora do regime Constitucional-Penal, a discussão sobre a legitimidade da proibição deste tipo de comércio poderá assumir outros rumos.

\footnotetext{
${ }^{305}$ ÁVILA, Gustavo Noronha de; GAUER, Gabriel José Chittó; GAUER, Rita Maria Chittó. Comércio de órgãos humanos: até onde vai a autonomia do indivíduo? Boletim IBCCRIM, São Paulo, ano 15, n. 175, p. 17-19, jun. 2007.

${ }^{306}$ ESTELLITA, Heloisa. op. cit., p. 341.

${ }^{307}$ Discorrendo sobre a situação na Alemanha, assevera Claus Roxin: "A regulamentação alemã deriva de um 'Tratado internacional para a proteção dos direitos humanos e da dignidade humana face ao emprego da biologia e da medicina', que fixa em seu art.21 um standard ético mínimo, segundo o qual o corpo humano e suas partes não podem ser utilizados para obter ganhos financeiros. Também no Parlamento alemão se considerou a violação à ética e à dignidade humana suficiente para fundamentar a punição. Está claro que, segundo a posição aqui defendida, isso não basta. Deve-se, isso sim, perguntar qual a pessoa lesionada se alguém decide que, em caso de morte, seus órgãos estarão disponíveis para fins de transplante desde que seja paga uma soma a seus herdeiros." (Estudos de direito penal, cit., p. 40-41).

${ }^{308}$ ESTELLITA, Heloisa. op. cit., p. 341.

309، Art. 199. A assistência à saúde é livre à iniciativa privada. (...). § $4^{\text {o }}$ - A lei disporá sobre as condições e os requisitos que facilitem a remoção de órgãos, tecidos e substâncias humanas para fins de transplante, pesquisa e tratamento, bem como a coleta, processamento e transfusão de sangue e seus derivados, sendo vedado todo tipo de comercialização".
} 


\subsection{Participação em suicídio}

O Código Penal brasileiro traz, em seu art.122, a criminalização da conduta da de induzir, instigar ou auxiliar alguém a praticar o suicídio ${ }^{310}$.

Trata-se de clássico exemplo da criminalização de uma participação em autolesão, reveladora, portanto, de uma intervenção estatal paternalista indireta.

Por se tratar de condutas diretamente relacionadas ao tema da disponibilidade da própria vida, opta-se por estudá-las em item próprio, juntamente com a questão da eutanásia e do homicídio a pedido ${ }^{311}$.

310،“Art. 122 - Induzir ou instigar alguém a suicidar-se ou prestar-lhe auxílio para que o faça: Pena - reclusão, de dois a seis anos, se o suicídio se consuma; ou reclusão, de um a três anos, se da tentativa de suicídio resulta lesão corporal de natureza grave".

${ }^{311}$ Vide item 5.1, infra. 


\section{PRINCÍPIO DA AUTORRESPONSABILIDADE E TEORIA DO CONSENTIMENTO}

Como visto, no atual modelo de Estado Constitucional de Direito, as normais constitucionais também devem pautar as construções dogmáticas, o que, em última análise, no campo do Direito Penal, sempre implica na determinação dos limites do poder punitivo. Em outras palavras, no atual contexto normativo, pode-se dizer que todos os institutos e teorias devem harmonizar-se com o conteúdo do Estado Democrático de Direito, sob pena de carência de legitimidade.

No âmbito do presente trabalho, interessa observar que, como se verá abaixo, a consagração do princípio constitucional da autorresponsabilidade impacta diretamente na chamada teoria do consentimento - entendida aqui como teoria que envolve o consentimento quanto ao próprio resultado de lesão e não apenas quanto ao risco de lesão -, provocando a sua necessária reformulação ${ }^{312}$.

Inicialmente, cumpre observar que, em termos gerais, o próprio nascimento do poder punitivo estatal, nos moldes atuais, se dá com a assunção do monopólio da violência legítima pelo Estado, o que representou um verdadeiro confisco do conflito por parte do Estado. No lugar do confronto entre indivíduos - pautado pela máxima "volenti

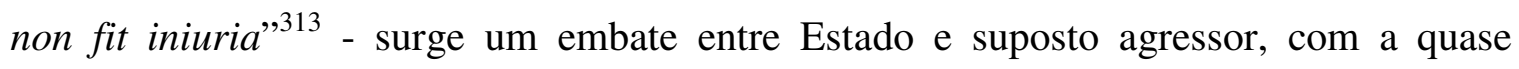
completa neutralização da figura da pretensa vítima ${ }^{314}$. Nessa linha, o delito é visto mais como um mal a toda a sociedade ou ao Estado do que como uma ofensa à determinada

\footnotetext{
${ }^{312}$ Também defendendo a reformulação da teoria do consentimento, baseada nos princípios constitucionais relacionados aos direitos e garantias individuais no âmbito de um Estado Democrático de Direito, cf. BECHARA, Ana Elisa Liberatore Silva. Da teoria do bem jurídico como critério de legitimidade do direito penal, cit., p. 180 e seg. Sobre o tema do consentimento, em sentido amplo, com inúmeras referências bibliográficas, cf. ANDRADE, Manuel da Costa. Consentimento e acordo em direito penal. Coimbra: Coimbra Ed., 2004.

313،Frente àquilo que se quer ou se aceita, não tem lugar nenhum injusto." Cf. ZAFFARONI, Eugenio Raúl. Derecho penal: parte general, cit., p. 498 e seg. ROXIN, Claus. Derecho penal: parte general, cit., t. 1, 7. p. 511 e seg.

${ }^{314}$ Cf. HERRERA MORENO, Myrian. La hora de la víctima. Madrid: Edersa, 1996. CANCIO MELIÁ, Manuel. Conducta de la víctima e imputacíon objetiva em derecho penal, cit., p. 31 e seg. HASSEMER, Winfried. Introdução aos fundamentos do direito penal. Porto Alegre: Safe, 2005. p. 110-124. "A característica diferenciada do poder punitivo é o confisco do conflito, ou seja, a usurpação do lugar de quem sofre o dano ou é vítima por parte do senhor (poder público), degradando a pessoa lesada ou vítima à condição de puro dado para a criminalização” (ZAFFARONI, Eugenio Raúl. O inimigo no direito penal, cit., p. 30).
} 
vítima, fato que justificaria a desvalorização da vontade ou do comportamento do indivíduo supostamente agredido ${ }^{315}$.

Com base nessa concepção, construiu-se uma clássica teoria do consentimento, com a elaboração de rígidos requisitos necessários para que se dê, apenas excepcionalmente, importância à vontade do titular do bem jurídico supostamente lesionado, conduzindo, eventualmente, à exclusão da tipicidade ou da ilicitude da conduta do agressor. Em linhas gerais, costuma-se apontar os seguintes requisitos: que a manifestação do ofendido seja livre, sem coação, fraude ou outro vício de vontade; que o ofendido, no momento de consentir, possua capacidade para fazê-lo, isto é, compreenda o sentido e as consequências de sua aquiescência; que se trate de bem jurídico disponível; que o fato típico se limite e se identifique com o consentimento do ofendido ${ }^{316}$.

Para o escopo deste trabalho, chama especial atenção a presença do requisito "disponibilidade do bem jurídico". Salienta-se que somente aqueles bens jurídicos dos quais o titular poderia legitimamente dispor podem ser objeto de consentimento quanto à lesão. Diante disso, surge uma questão fundamental: como determinar quais são os bens jurídicos disponíveis e quais são os indisponíveis?

A doutrina penal, de um modo geral, quase sempre olvidando-se da existência de uma Constituição e do vigente modelo de Estado Constitucional e Democrático de Direito, não mede esforços na tentativa de encontrar um critério diferenciador. Em primeiro lugar, afasta-se a possibilidade do consentimento quando envolver ataques a bens jurídicos coletivos ou supraindividuais. Em seguida, sugere-se a utilização do critério da contrariedade aos usos, aos bons costumes, à moral social dominante, ou à

\footnotetext{
315“Todas las víctimas son ya la misma víctima: la sociedad; y todas las victimizaciones típicas conculcan fundamental prioritariamente el orden penal del Estado. Se corona, em suma, el definitivo proceso de evaporacíon victimal." (HERRERA MORENO, Myrian. op. cit., p. 63-64). Cf., ainda, traçando um breve panorama histórico e defendendo a mudança de paradigma, com a consideração do comportamento da suposta vítima no âmbito da teoria do delito, falando-se até mesmo em um "redescobrimento da vítima por parte das ciências penais", SILVA SÁNCHEZ, Jesús María. La consideracion del comportamiento de la victima en la teoria juridica del delito, cit., p. 163-194. CANCIO MELIÁ, Manuel. La exclusión de la tipicidad por la responsabilidad de la víctima: imputación a la víctima, cit., p. 49-99. Cf., ainda, MARINHO, Renato Silvestre. A relevância do comportamento da vítima no direito penal: novos caminhos. Boletim IBCCRIM, São Paulo, v. 18, p. 12-13, 2010.

${ }^{316}$ Assim, p. ex., TOLEDO, Francisco de Assis. Princípios básicos de direito penal. 5. ed. São Paulo: Saraiva, 1994. p. 215. BITENCOURT, Cezar Roberto. Tratado de direito penal. 13. ed. São Paulo: Saraiva, 2008. v. 1, p. 310. De modo semelhante, DIAS, Jorge de Figueiredo. Direito penal: parte geral. São Paulo: Ed. Revista dos Tribunais, 2007. p. 478-488. Cf., ainda, BETTIOL, Giuseppe. Direito penal. São Paulo: Ed. Revista dos Tribunais, 1966. v. 1, p. 395-408. ANTOLISEI, Francesco. Manuale di diritto penale: parte generale. 14. ed. Milano: Giuffrè, 1997. p. 281-291.
} 
ordem pública como fator impeditivo ao reconhecimento do consentimento do ofendido ${ }^{317}$. Além disso, menciona-se o caráter de "direito fundamental da personalidade" como causa de indisponibilidade do bem jurídico ${ }^{318}$. Por fim, há quem sustente a existência de uma relação direta entre a espécie de ação penal - se de iniciativa pública incondicionada ou condicionada à representação do ofendido ou se de iniciativa privada - e a condição de disponibilidade ou não do bem.

Logo de início, admitindo-se ser correto o critério de distinção entre bem jurídicos individuais e coletivos, deve-se atentar, como já exposto, para o fato de que a criação de bens jurídicos coletivos muitas vezes ser utilizada como instrumento na tentativa desesperada de legitimar incriminações. Procura-se, frequentemente, mesmo diante de evidente lesão direta a bem jurídicos individuais, atribuir uma imaginária ou indireta lesão a um bem jurídico coletivo de duvidosa legitimidade, permitindo, entre outros, a antecipação da intervenção penal, a exacerbação de penas, e impedindo qualquer consideração da vontade do real titular do bem jurídico lesionado. É o que parece ocorrer, por exemplo, como já salientado, nos crimes de uso e tráfico de drogas. Busca-se, de toda forma, sustentar a existência de uma suposta ofensa à "coletividade". Criando-se falsos bem jurídicos coletivos afasta-se, por completo, a discussão que integra a teoria do consentimento.

No que tange ao segundo ponto, mais uma vez necessário consignar que, no Estado Democrático de Direito, "usos", "bons costumes" e "moral social dominante" não são fundamentos idôneos a justificar a atuação do poder punitivo estatal. Como já colocado, o princípio da autorresponsabilidade assegura a cada um o direito de escolher a quais costumes ou a qual moral deseja se filiar, ainda que minoritários, ou até mesmo, de optar por criar seu próprio padrão individual. O termo "ordem pública", detentor de enorme abstração, aparece somente como um "rótulo" diferente às expressões anteriores, não merecendo melhor sorte. Desconsiderar a vontade do indivíduo por tais razões significa mais uma tentativa de imposição, por meio do poder punitivo, de um padrão de conduta desejável pela maioria ou moralmente dominante, deslocando o indivíduo do centro do ordenamento jurídico, o que é incompatível com o vigente modelo de Estado.

\footnotetext{
${ }^{317}$ PIERANGELI, José Henrique. O consentimento do ofendido na teoria do delito. 3. ed. São Paulo: Ed. Revista dos Tribunais, 2001. p. 119-128.

${ }^{318}$ Jorge de Figueiredo Dias fala em “direitos da personalidade elementares" (Direito penal: parte geral, cit., p. 480).
} 
Quanto ao terceiro critério apontado, o fato de um direito ser classificado como fundamental da personalidade, até por razão de lógica, não pode ter o condão de impedir a sua livre disposição por seu titular. Ao contrário, quanto mais importante juridicamente o bem jurídico maior deveria ser o poder de decisão do indivíduo sobre ele.

Aliás, no modelo de Estado Democrático de Direito, não é legítimo ao Estado impor o que é importante e o que não é para cada indivíduo. O Estado, exercendo seu papel de garantidor de direitos individuais, estabelece um regime jurídico especial de proteção àqueles direitos que considera fundamentais. Mas isso não significa, em hipótese alguma, que essa proteção deva operar-se mesmo contra a vontade de seu titular. O princípio da autorresponsabilidade determina que cada pessoa é livre para avaliar qual a importância daquele seu bem jurídico individual - criando a sua própria hierarquia de valores - e o que deseja fazer com ele. Em outras palavras, um direito jurídico fundamental jamais pode ser transfigurado em dever jurídico fundamental, imposto contra a vontade de seu titular ${ }^{319}$. Dessa forma, por exemplo, o direito à propriedade jamais pode ser convertido em dever à propriedade $\left(\mathrm{CF}\right.$, art. $\left.5^{\circ}, \mathrm{XXII}\right)$, assim como o direito à preservação da honra $\left(\mathrm{CF}\right.$, art. $\left.5^{\circ}, \mathrm{X}\right)$ nunca pode ser entendido como dever à preservação da honra.

No que tange ao critério referente à espécie de ação penal, trata-se, em primeiro lugar, de construção vinculada ao anterior modelo de Estado Legal de Direito, pelo que deixa de considerar a normativa constitucional de hierarquia superior e consagra a total e ilimitada liberdade do legislador ordinário para a definição da disponibilidade ou não de um bem jurídico. Além do mais, parece revelar uma imprecisão técnica inaceitável, confundindo-se institutos de naturezas diversas, misturando-se uma análise pertencente à estrutura jurídica do delito com a titularidade da ação penal ou com uma condição objetiva de procedibilidade. Para se ter uma ideia da gravidade da problemática, basta dizer que a escolha da pretensa vítima acerca da disponibilidade ou não de seu bem jurídico ocorre sempre antes ou durante a pretensa conduta delituosa, enquanto a manifestação acerca do desejo de representar ou de ingressar com uma ação penal contra

\footnotetext{
319، Interesse juridicamente reconhecido não pode ser convertido em dever jurídico, imposto contra a vontade de seu titular". (BECHARA, Ana Elisa Liberatore Silva. Da teoria do bem jurídico como critério de legitimidade do direito penal, cit., p. 185).
} 
o agressor é sempre pós-fato, envolvendo fatores e condições completamente diversos, o que evidencia a incongruência entre os institutos ${ }^{320}$.

Na realidade, no modelo de Estado Democrático de Direito, pluralista por excelência, o princípio constitucional da autorresponsabilidade assegura a cada indivíduo a escolha da forma de vida que desejar, no exercício de sua autodeterminação, o que, logicamente, inclui a livre gestão de seus próprios bem jurídicos. Decidir o destino de sua vida, de seus bens jurídicos, seja ele qual for, afigura-se como verdadeira concretização do direito ao livre desenvolvimento ${ }^{321}$. Pretender assentar a indisponibilidade de determinados bens jurídicos individuais, com a atuação do poder punitivo sobre aquele que lesiona o bem jurídico com o consentimento inequívoco de seu titular, acaba, dessa forma, por revelar uma ilegítima atuação estatal paternalista indireta ${ }^{322}$.

\footnotetext{
320،É preciso destacar que o consentimento não se assemelha à renúncia ao direito de queixa extintiva da punibilidade, pois sucede depois do fato delituoso, repercutindo sobre as consequências do crime, enquanto o consentimento deve ser anterior ou concomitante à prática da ação delituosa." (REALE JÚNIOR, Miguel. Instituições de direito penal, cit., p. 173). De modo semelhante, BETTIOL, Giuseppe. op. cit., p. 400-401.

${ }^{321}$ “'El argumento decisivo para la aceptación de que todo consentimiento eficaz excluye el tipo radica en la teoría liberal, aquí desarrollada, del bien jurídico referido al individuo. Si los bienes jurídicos sirven para el libre desarrollo del individuo, no puede existir lesión alguna del bien jurídico cuando una acción se basa en una disposición del portador del bien jurídico que no menoscaba su desarrollo, sino que, por el contrario, constituye su expresión" (ROXIN, Claus. Derecho penal: parte general, cit., p. 517).

${ }^{322}$ Também afirmando que a disponibilidade do bem jurídico por seu titular decorre do texto constitucional, rechaçando o que chama de "paternalismo autoritário", a lição de Eugênio Raúl Zaffaroni: "La expropiación del conflicto en los siglos XIII y XIV retomó el principio imperial en contra de la víctima, lo que sólo en el siglo XVIII fue atemperado con el principio de ofensividad. Sin embargo, la posterior tarea de demolición del derecho penal liberal volvió a la carga con el principio imperial, argumentando que el interés público no podía quedar sometido a la voluntad de un particular, lo que llevó a rechazar la relevancia eximente de la aquiescencia. Esta reacción antiliberal implicaba la confiscación o estatización de todos los bienes jurídicos, es decir, que todos tendrían um único titular que sería el estado que, a su vez, se proclamaba titular de un pretendido derecho subjetivo o jus puniendi y, en último análisis, el mentado jus puniendi se erigiría en único bien jurídico. Esta pretensión es inadmisible e incluso el concepto de jus puniendi no pasa de ser una racionalización legitimante de la potentia puniendi, que es lo único que existe en el mundo real. Lo contrario es claro paternalismo autoritario, pues cuando el poder punitivo no reconoce la relevancia eximente del consentimiento, desconoce a la víctima o sólo la admite con un signo que habilita la confiscación. El argumento por el que se impone la eficacia eximente de la aquiescencia es constitucional: no hay lesividad cuando un hecho no afecta a otro por daño o por peligro ni tampoco cuando el habitante consiente ciertos cursos de acciones que pueden ser dañinos o peligrosos para el ente con el que se relaciona. Cuando se pretende separar al bien jurídico de su titular, no se hace otra cosa que destruir o negar el concepto mismo de bien jurídico: si su esencia es la relación de disponibilidad, es imposible negar el valor eximente de la aquiescencia. El desconocimiento de la relevancia de ésta a los efectos de la prohibición es un nuevo esfuerzo por subordinar a la víctima. Cualquier intervención punitiva alcanza un grado intolerable de irracionalidad cuando pretende que el habitante use el bien jurídico sólo en determinada forma; esta pretensión es propia de un estado que no respeta la autonomía de la conciencia (la persona) ni el concepto personalista del derecho, sino de un derecho transpersonal que subordina al humano a metas trascendentes de su humanidad, es decir, idolátricas (la raza, la nación, la dictadura, el régimen, etc.). La pretendida tutela de un bien jurídico más allá de la voluntad de su titular es un pretexto para penar un pragma no conflictivo y, por ende, es violatoria del art. 19 constitucional" (Derecho penal: parte general, cit., p. 498-499).
} 
Por tudo isso, a conclusão a que se chega é a de que, em um Direito Penal Constitucional-Democrático, todo bem jurídico individual encontra-se na esfera de disponibilidade de seu titular, sendo ilegítima a atuação punitiva estatal que desconsidere a sua vontade individual ${ }^{323}$.

Para ilustrar a tese acima defendida, muitos poderiam ser os exemplos de situações específicas oferecidos neste ponto. Todavia, por razões metodológicas, parte-se, desde já, para a hipótese considerada extrema, qual seja, a da análise da disponibilidade ou não do bem jurídico "vida".

\subsection{Vida e consentimento: participação em suicídio, eutanásia e homicídio a pedido}

Verifica-se, nos últimos tempos, que o debate em torno das delicadas questões que envolvem a vida e a morte vem ganhando cada vez mais destaque, não somente no âmbito do Direito ${ }^{324}$, mas também no seio de diversos outros ramos da ciência.

Nada obstante, especificamente no Direito Penal, ainda que se observe um certo aquecimento do debate em torno do aborto e da eutanásia, parece ainda prevalecer um consenso quase absoluto: a vida se afigura como um bem jurídico indisponível. Na realidade, a sensação é a de estar-se diante de verdadeiro dogma, o qual, sob forte influência dos padrões religiosos e morais ${ }^{325}$, ultrapassando os séculos, transformou-se em verdadeiro tabu ${ }^{326}$.

\footnotetext{
${ }^{323}$ Defendendo a impossibilidade da proteção de um interesse individual contra a vontade do respectivo titular, cf., p. ex., SCHÜNEMANN, Bernd. op. cit., p. 32 e seg. BECHARA, Ana Elisa Liberatore Silva. Da teoria do bem jurídico como critério de legitimidade do direito penal, cit., p. 187 e seg.

${ }^{324} \mathrm{Cf}$., p. ex., COSTA, José de Faria; GODINHO, Inês Fernandes (Orgs.). As novas questões em torno da vida e da morte no direito penal. Coimbra: Coimbra Ed., 2010. Numa perspectiva norte-americana, DWORKIN, Ronald. Domínio da vida: aborto, eutanásia e liberdades individuais. São Paulo: Martins Fontes, 2009. FEINBERG, Joel. Harm to self: the moral limits of criminal law, cit., v. 3, p. 344-374.

${ }^{325} \mathrm{~A}$ impressão que se tem é que o argumento se baseia na ideia, apresentada muitas vezes de forma velada ou até inconsciente, de que a vida é um valor "sagrado", um "dom divino" e, por essa razão, é evidente que o homem não possui livre domínio sobre ela.

${ }^{326}$ Cf. BECHARA, Ana Elisa Liberatore Silva. Da teoria do bem jurídico como critério de legitimidade do direito penal, cit., p. 182-184.
} 
A doutrina penal, de um modo geral, não costuma a perder muito tempo com o tema, geralmente consignando, de forma irrefletida e pouco fundamentada, a indisponibilidade da vida por seu próprio titular. Assim, para justificar tal postura, limita-se a afirmar que a vida possui altíssima relevância ${ }^{327}$, que ocupa o primeiro e indisputado lugar na hierarquia dos bens jurídicos dignos e carecidos de tutela ${ }^{328}$, que é bem jurídico de incontestável magnitude ${ }^{329}$, que ocupa um lugar especial entre os bens jurídicos individuais ${ }^{330}$,que se apresenta como valor social que transcende o interesse particular de seu titular ${ }^{331}$, que constitui elemento necessário de todos os demais direitos ${ }^{332}$, ou que, simplesmente, seria um bem jurídico indisponível por excelência ${ }^{333}$. Com base em argumentos dessa espécie, destacando sempre o grau de importância da vida, busca-se legitimar a intervenção penal sobre qualquer tipo de conduta que lesione ou coloque em risco tal bem jurídico, independentemente da vontade de seu titular.

O fundamento da punição parece bem claro: o Estado considera a vida um bem de máxima importância e, por essa razão, busca preservá-la de todas as formas por meio da atuação de seu poder punitivo, mesmo contra a vontade de seu titular. Nessa linha, dado o caráter essencial desse bem jurídico, entende-se que o atentado do indivíduo contra a sua própria vida, ou o seu consentimento ou o pedido para que outrem o faça, contrariaria a própria natureza das coisas, os bons costumes, e a moral pública dominante.

Em primeiro lugar, não há como deixar de ressaltar, novamente, a lógica incompreensível de que se parte: assevera-se que quanto mais importante o bem jurídico individual menor o poder de disposição do indivíduo sobre ele. Ora, qualquer reflexão

\footnotetext{
${ }^{327}$ FRAGOSO, Heleno Cláudio. Lições de direito penal, cit., v. 1, p. 32 e 55-56.

${ }^{328}$ DIAS, Jorge de Figueiredo. op. cit., p. 480.

${ }^{329}$ PRADO, Luiz Regis. Curso de direito penal brasileiro, cit., v. 2, p. 83.

${ }^{330}$ JESCHECK, Hans-Heinrich. Tratado de derecho penal: parte general. 4. ed. Granada: Comares, 1993. p. 341.

${ }^{331}$ MIR PUIG, Santiago. Derecho penal: parte general, cit., p. 520. No mesmo sentido, afirmando que a integridade do bem "vida" responde a um interesse não somente de um indivíduo, mas também da coletividade, cf. MARINUCCI, Giorgio; DOLCINI, Emilio. Manuale di diritto penale, cit., p. 229. Cf., ainda, ANTOLISEI, Francesco. op. cit., p. 286.

${ }^{332}$ BITENCOURT, Cezar Roberto. Tratado de direito penal. 8. ed. São Paulo: Saraiva, 2008. v. 2, p. 24.

${ }^{333}$ GRECO, Rogério. Curso de direito penal: parte geral. Niterói: Impetus, 2008. p. 379.
} 
racional conduz à conclusão completamente oposta: quanto mais importante o bem jurídico individual maior deveria ser o poder de decisão do indivíduo sobre ele ${ }^{334}$.

Para colocar em termos bens claros, trata-se da afirmação de que a vida de cada pessoa não está sob o seu domínio, não diz respeito a ela, mas sim ao Estado ou a qualquer interesse social ou moral. Cria-se uma obrigação jurídica de viver, de manter-se vivo, sendo absolutamente irrelevante a vontade do indivíduo. Retira-se a pessoa do centro, colocando em seu lugar um suposto interesse da coletividade.

Trata-se, talvez, da forma mais grave de paternalismo estatal, responsável por retirar do indivíduo o comando sobre a sua própria vida, sendo certo que, embora possa parecer paradoxal, colocar fim à própria vida está justamente entre as diversas opções de vida. Uma sociedade não pode ser considerada livre se seus membros não tiverem o direito de dispor de seus próprios corpos ${ }^{335}$.

No Estado Democrático de Direito, tolerante perante todas as formas de vida que não causem danos a terceiros, o princípio da autorresponsabilidade assegura a cada um a possibilidade de optar pela forma de vida que desejar, ainda que supostamente contrária à "natureza das coisas" ou à moral e aos bons costumes, o que inclui, logicamente, o direito de, dentro das possibilidades físicas, escolher o momento e a forma de sua morte, no pleno exercício de sua liberdade de autodeterminação. Por essa razão, não se mostra exagerado falar em um verdadeiro direito de morrer ${ }^{336}$, afigurando-se

\footnotetext{
${ }^{334}$ Sobre o tema, importante a lição de Roberto Dias, citando Jorge Reis Novais: “A renúncia é também uma forma de exercício do direito fundamental, dado que, por um lado, a realização de um direito fundamental inclui, em alguma medida, a possibilidade de se dispor dele, inclusive no sentido da sua limitação, desde que esta seja uma expressão genuína do direito de autodeterminação e livre desenvolvimento da personalidade individual. ( $O$ direito fundamental à morte digna: uma visão constitucional da eutanásia. Belo Horizonte: Fórum. 2012. p. 125).

${ }^{335}$ VIANNA, Túlio. O direito ao próprio corpo. Fórum, São Paulo, p. 18-19, 10 jan. 2012. Destaca o autor, ainda, na mesma linha da tese aqui sustentada, que "o direito ao próprio corpo ainda está longe de ser conquistado e reconhecido como um direito fundamental da pessoa humana. As normas limitando a autonomia dos corpos estão por todas as partes: limitações à sexualidade, ao uso de drogas psicotrópicas, à liberdade de expressão e até mesmo à vida e à morte. Tudo em nome de um suposto bem maior: a coletividade. A maioria destas normas de regulação dos corpos, porém, não evita que haja lesão a direito alheio, mas tão somente impõe um modelo de conduta que a maioria julga adequado; (...).A grande batalha jurídica do século XXI será pela libertação dos corpos das normas impostas pelo arbítrio da maioria. Somos herdeiros de uma cultura religiosa que nos impôs ao longo da história uma infinidade de restrições morais e, posteriormente jurídicas, ao uso de nossos próprios corpos.".

${ }^{336}$ Defendendo a existência de um "direito de morrer": BECHARA, Ana Elisa Liberatore Silva. Da teoria do bem jurídico como critério de legitimidade do direito penal, cit., p. 186. LÓPEZ DÍAZ, Claudia. op. cit. VIANNA, Túlio. O direito ao próprio corpo, cit., p. 18-19. Id. Sobre o direito à própria morte. Fórum, São Paulo, p. 14-15, 10 set. 2012. Em sentido contrário, BITENCOURT, Cezar Roberto. op. cit., v. 2, p. 99. MENDES, Gilmar Ferreira et al. op. cit., 2012, p. 294-297.
} 
ilegítima a imposição estatal, por meio de seu poder punitivo, da manutenção da vida de quem quer que seja.

Importante observar que o que a Constituição brasileira de 1988 garante é o direito fundamental à vida (art. $5^{\mathrm{a}}$, caput), o que, como visto, jamais pode ser transfigurado em um inexistente dever fundamental à vida ${ }^{337}$. Assim como ao Estado não é legítimo obrigar ninguém a manter-se com saúde ${ }^{338}$, também não o é obrigar alguém a manter-se vivo, independentemente das circunstâncias. A vida, como todo bem jurídico penal individual, encontra-se inteiramente à disposição de seu titular, não sendo legítima a intervenção penal que desconsidere a sua vontade ${ }^{339}$.

A vida imposta contra a vontade de seu titular não é constitucionalmente admissível, podendo-se falar, até mesmo, em violação da própria dignidade humana, tendo em vista a patente instrumentalização do indivíduo com vistas à satisfação de interesses de terceiros.

\footnotetext{
337،“A expressão 'inviolabilidade do direito à vida', consagrada constitucionalmente, não indica que a vida é um dever para consigo mesmo e para com os outros, tampouco pode ser entendida como um direito absoluto, indisponível ou irrenunciável, Nos termos da Constituição, a 'inviolabilidade' de tal direito significa que ele não tem conteúdo econômico-patrimonial e, mais do que isso, ninguém pode ser privado delo arbitrariamente. Nesse sentido é que ele deve ser entendido como indisponível: ninguém pode dispor da vida de outrem A inviolabilidade da vida tem que ver com terceiros, cuja ação contra a vida alheia é coibida, mas não se pode ler o texto constitucional de forma a proibir que qualquer pessoa decida a duração da sua vida". (DIAS, Roberto. op. cit., p. 122-123).

${ }^{338}$ Partindo do princípio do livre desenvolvimento da personalidade - também previsto na Constituição espanhola - para afirmar "la disponibilidad de la salud" e, por consequência, a relevância do consentimento no caso de lesões, cf. BERDUGO GÓMEZ DE LA TORRE, Ignacio. El consentimiento en las lesiones veinte años después. In: NIETO MARTíN, Adán. Homenaje al Dr. Marino Barbero Santos in memorian II. Cuenca: Ediciones de la Universidad de Castilla-La Mancha: Universidad Salamanca, 2001. v. 2.

${ }^{339}$ Nesse sentido, posiciona-se Ana Elisa Liberatore Silva Bechara: "Entende-se que, em um contexto democrático e laico, o indivíduo que, consciente e voluntariamente, consente a própria morte age no exercício de sua liberdade de autodeterminação e, assim, de sua dignidade. (...). O interesse sobre a vida humana, tal como diversos outros bens jurídicos de natureza individual, concerne tão somente a seu titular, respeitando-se a busca de seu próprio desenvolvimento no seio da sociedade. Não havendo mais referido interesse individual, não é possível continuar a afirmar a tutela da vida, que perde, nessa hipótese, o sentido de bem jurídico para justificar a intervenção penal". (Da teoria do bem jurídico como critério de legitimidade do direito penal, cit., p. 185). Do modo semelhante, Günther Jakobs: "La respuesta a la pergunta por el sentido de la vida no viene de la esfera de lo público, sino en todo caso del ámbito privado. Em tal época, la autolesíon de personas responsables, hasta la autodestruccíon, no puede constituir um injusto, como tampoco puede serlo la participacíon en ella, ni siquiera la heterolesíon con consentimento o participacíon a próprio riesgo del lesionado. Una lesíon que no se produce por arrogacíon del ámbito de organizacíon de otro, sino que, en cambio, tambíen constituye una autoorganizacíon de esta persona responsable, sólo de manera aparente vulnera algún bien personal; en realidade se trata de una forma (más o menos habitual o inusual, pero en todo caso privada) de modelar la vida de cada uno, que no sólo puede llevarse a cabo de propria mano, sino tambíen en régimen de divisíon de tareas." (La organización de autolesión y heterolesión, especialmente en caso de muerte. In: JAKOBS, Günther. Estudios de derecho penal. Madrid: Civitas, 1997. p. 395).
} 
A hierarquia de bens jurídicos traçada pela Constituição, a qual determina regimes especiais de proteção, não pode ser confundida com obrigação de tutela mesmo contra a vontade do titular. Cada pessoa é livre para desenhar a hierarquia de seus próprios bens jurídicos, não obrigatoriamente colocando a sua vida em primeiro lugar. Verifica-se, novamente, uma tentativa do Estado de imposição de um padrão dominante, o que é inaceitável no atual modelo de Estado. Dessa forma, é perfeitamente possível, por exemplo, que uma determinada pessoa coloque o seu bem jurídico honra ou patrimônio em grau hierarquicamente superior a seu bem jurídico vida. De igual maneira, um indivíduo pode considerar a obediência a preceitos religiosos mais importante do que a preservação de sua própria vida, como ocorre nos famosos casos de transfusão de sangue envolvendo testemunhas de Jeová.

Vale pontuar, ainda, que a disponibilidade da vida, constitucionalmente assegurada, não pode ser suprimida com base em alegações relativas à dificuldade em se aferir a real capacidade ou seriedade do consentimento. De fato, a disposição da vida parece enfrentar situações das mais diversas complexidades, no que tange, por exemplo, à forma, ao momento, à capacidade, à pessoa autorizada para consentir nos casos de inconsciência do titular, etc. Cabe à doutrina, à jurisprudência e aos legisladores pensar, elaborar e colocar em prática um regime normativo que estabeleça, com todas as cautelas necessárias, apoiados na ciência médica, seguros critérios para verifique a presença efetiva do consentimento válido, tudo com o objetivo de verificar a real vontade do indivíduo, concretizando, assim, o princípio da autorresponsabilidade. O que não é possível, revestindo-se até mesmo de incoerência científica, é violar um princípio constitucional, consignando uma suposta indisponibilidade da vida, sob a desculpa de que se mostra difícil a análise da presença dos requisitos do consentimento.

Importante destacar, novamente, que, por todas as razões já esposadas, danos indiretos ou remotos a terceiros, tais como eventuais prejuízos sociais decorrentes da perda de uma pessoa ou até mesmo a tristeza de uma mãe que perde um filho, ao menos no âmbito do Estado Democrático de Direito, não têm o condão de legitimar uma incriminação. Sustentar o contrário significaria fazer letra morta o direito fundamental à liberdade de autodeterminação, vez que toda ou quase toda ação autolesiva provoca danos indiretos a terceiros. 
Diante do cenário acima descrito, passa-se, agora, à análise dos principais temas relacionados à disponibilidade da vida, quais sejam, o tipo penal de participação em suicídio, a prática da eutanásia, e o cometimento de homicídio a pedido.

O crime de participação em suicídio está previsto no art.122 do Código Penal, estendendo o poder punitivo estatal às condutas de "induzir ou instigar alguém a suicidar-se ou prestar-lhe auxílio para que o faça”. Trata-se de clássico exemplo de criminalização da participação em autolesão, reveladora de evidente paternalismo indireto $^{340}$.

Considera-se o suicídio necessariamente um $\mathrm{mal}^{341}$ e, ao mesmo tempo, o indivíduo incapaz de fazer suas próprias escolhas, facilmente influenciável por terceiros, e, por essa razão, merecedor da tutela do Estado mesmo contra a sua vontade. Argumenta-se, ainda, que aquele potencial suicida sempre se encontraria em situação de vulnerabilidade, em estado de insanidade ou de profunda depressão, e, assim, incapaz de exprimir livremente a sua vontade.

Em primeiro lugar, considerar o suicídio necessariamente um mal já se afigura, no mínimo, extremamente problemático, eis que revela a realização de juízos predominantes morais e religiosos, estes últimos fundados na ideia de que a vida humana seria um dom divino, alheio às decisões dos homens ${ }^{342}$. Além disso, associar obrigatoriamente o potencial suicida a uma situação de vulnerabilidade, insanidade ou patologia - exigência, ressalte-se, não constante do tipo penal - também parece se mostrar preconceituoso e moralista. Por mais incrível que possa parecer, a opção pelo suicídio pode ser mais livre, consciente e sadia do que, por exemplo, a opção por ter um filho ou por fazer uma cirurgia plástica. Um homem pode perfeitamente decidir, com base em infinitas razões, que vale a pena viver somente até os 60 anos de idade ou que não vale a pena viver sentado em uma cadeira de rodas, por exemplo. É preciso ter em mente que morrer pode

\footnotetext{
${ }^{340}$ Cf. ESTELLITA, Heloisa. op. cit., p. 338.

${ }^{341}$ Segundo a lição de Heleno Cláudio Fragoso, seguida por muitos, "o fato de não ser considerado crime não significa que o suicídio seja indiferente para o direito. Ofende ele interesses morais e demográficos do Estado, somente não sendo punível pela absoluta inutilidade e injustiça da pena, mesmo na forma tentada". (Lições de direito penal, cit., v. 1, p. 55). Para Cezar Roberto Bitencourt, "o ordenamento jurídico vê no suicídio um fato imoral e socialmente danoso". (Tratado de direito penal, cit., v. 2, p. 100).

${ }^{342}$ De modo similar, cf. BECHARA, Ana Elisa Liberatore Silva. Da teoria do bem jurídico como critério de legitimidade do direito penal, cit., p. 182 e seg.
} 
ser uma opção livre e consciente de vida, e esta decisão pode ser tomada com ou sem a participação de terceiro $^{343}$.

Dessa forma, conclui-se que o crime previsto no art.122 do Código Penal não foi recepcionado pela ordem constitucional inaugurada em $1988^{344}$. Da mesma forma, devem ser lidas à luz da Constituição as hipóteses previstas no art.146, $\S 3^{\circ}$, do Código Penal, que excluem o constrangimento ilegal quando, mesmo sem o consentimento do indivíduo, a intervenção médica se justifique por iminente perigo de vida ou a coação tiver como objetivo impedir o suicídio. No primeiro caso, havendo a possibilidade de se aferir a vontade do paciente, esta deve obviamente prevalecer ${ }^{345}$. Já no segundo caso, nada parece justificar a legitimidade de uma coação para impedir a livre disposição da vida ${ }^{346}$.

Tudo o que foi dito acima pode ser utilizado na análise das hipóteses de eutanásia e homicídio a pedido.

No que tange à eutanásia e suas variantes ${ }^{347}$, deslegitimando a intervenção penal, acrescentam-se ao princípio da autorresponsabilidade argumentos de cunho humanitário e a referência mais direta à dignidade humana ${ }^{348}$. Por certo é grande a

\footnotetext{
${ }^{343}$ Afirmando o suicídio como "manifestação da autonomia" e "produto da autodeterminação", partindo do princípio da autorresponsabilidade, cf. MEDINA FRISANCHO, José Luis. op. cit., p. 227-272.

${ }^{344}$ Em sentido contrário, embora reconhecendo o caráter paternalista da incriminação, PASCHOAL, Janaína Conceição; REALE JÚNIOR, Miguel. Auxílio ao suicídio, infanticídio e aborto. In: REALE JÚNIOR, Miguel. (Coord.). Direito penal: jurisprudência em debate: crimes contra a pessoa. Rio de Janeiro: GZ, 2011. v. 1, p. 46-55.

${ }^{345}$ Neste ponto, apontando para a inconstitucionalidade do dispositivo do art.146, $\S 3^{\circ}$, do Código Penal, por afronta ao princípio da autonomia, rejeitando este tipo de atuação paternalista do Estado, cf. In: REALE JÚNIOR, Miguel. (Coord.). Direito penal: jurisprudência em debate: crimes contra a pessoa, cit., v. 1, p. 187 e seg.

${ }^{346}$ Pode-se, talvez, admitir, excepcionalmente, uma espécie de intervenção ou contenção temporária, de caráter não penal, pelo Estado ou pelo particular, com o objetivo de proporcionar tempo para uma melhor reflexão pessoal. Sobre o tema, cf. HIRSCH, Andrew von. op. cit., p. 11-28.

${ }^{347}$ Considera-se eutanásia "a ajuda que presta a uma pessoa gravemente doente, a seu pedido ou menos levando em conta a sua vontade presumida, no sentido de proporcionar-lhe uma morte em consonância com a sua concepção de dignidade humana" (ROXIN, Claus. Estudos de direito penal, cit., p. 189). Cf. NÚÑEZ PAZ, Miguel Ángel. Homicidio consentido, eutanasia y derecho a morrir com dignidad. Madrid: Tecnos, 1999. p. 31-173.

348“De fato, do mesmo modo que ocorre nas hipóteses de auxílio a suicídio, também na eutanásia se está diante objetivamente de um desinteresse pela própria vida, que apenas deve dizer respeito ao seu titular, dotado de dignidade e, assim, de autonomia e autorresponsabilidade. Na verdade, tem-se, nos mencionados casos, a tentativa de proteção penal do titular do bem jurídico contra as suas próprias ações, o que constitui uma legislação penal paternalista e, portanto, ilegítima”. (BECHARA, Ana Elisa Liberatore Silva. Da teoria do bem jurídico como critério de legitimidade do direito penal, cit., p. 187). "Em um Estado Democrático de Direito, em que o primeiro pilar é o respeito à dignidade humana, não pode um médico ser responsabilizado criminalmente, seja a título de omissão de socorro (para os que não o tomam como garantidor), seja a título de homicídio, sobretudo doloso (para os que o tomam como tal), por ter respeitado
} 
complexidade e o número de situações que envolvem a disponibilidade da vida do indivíduo enfermo, o que, como já ressaltado, exige o desenvolvimento de instrumentos para que se possa aferir a presença e a seriedade do consentimento, ainda que na forma presumida ${ }^{349}$ ou por declaração anterior de vontade (testamento vital ou living will), a relevância da vontade de parentes ou representantes nos caso de inconsciência, e, também, para que se discipline a atuação de médicos e dos demais profissionais de saúde ${ }^{350}$.

Guardando estrita relação com a eutanásia encontra-se o homicídio a pedido ${ }^{351}$. Nesse caso, o indivíduo, independentemente da presença de qualquer doença, solicita a outrem que o mate. Por mais escandalosa que possa parecer em um primeiro momento, a hipótese apresenta uma fronteira muito tênue com o delito de participação em suicídio. Se uma pessoa, por exemplo, fornece um pequeno banco para que sirva de suporte para que alguém se suicide pendurado numa corda, cometeria o crime de participação em suicídio. Caso esta mesma pessoa resolva retirar o banco para que o enforcamento se produza, o crime passaria a ser o de homicídio, na forma de homicídio a pedido ${ }^{352}$. Pode-se dizer, buscando-se uma classificação técnica, que se passaria de uma participação em autolesão

a vontade do paciente. Como profissional, o médico tem o dever de agir para preservar a vida, mas como indivíduo tem o direito de optar respeitar a decisão de outro indivíduo conduzir sua vida como bem entende, ainda que sua escolha leve à morte" (PASCHOAL, Janaína Conceição. Ingerência indevida: os crimes comissivos por omissão e o controle da punição do não fazer, cit., p. 190). Miguel Reale Júnior, no contexto da chamada ortotanásia, defende a existência de um "direito à morte digna". Cf. Morte digna. In: REALE JÚNIOR, Miguel. Discursos sobre o Brasil. São Paulo: Saraiva, 2012. p. 245-248. Também defendendo o direito à morte digna, sob uma perspectiva constitucional, cf. DIAS, Roberto. op. cit.

${ }^{349}$ Sobre o consentimento presumido, cf. ANDRADE, Manuel da Costa. Consentimento em direito penal médico: o consentimento presumido. Revista Portuguesa de Ciência Criminal, Coimbra, ano 14, n. 1/2, p. 117-148, 2004.

${ }^{350}$ Para um estudo acerca dos critérios para se afirmar a existência de um "suicídio autorresponsável", no âmbito da eutanásia, partindo do princípio constitucional da autorresponsabilidade, cf. MEDINA FRISANCHO, José Luis. op. cit., p. 227-272.

${ }^{351} \mathrm{Na}$ Alemanha, p. ex., onde a participação em suicídio não é criminalizada, há um tipo penal específico, com pena reduzida quando comparada ao homicídio "comum", para a conduta de homicídio a pedido (§ 216 do Código Penal alemão). Na Espanha, há a punição da participação em suicídio com uma previsão especial da figura do homicídio a pedido (art.143 do Código Penal Espanhol). No Brasil, o agente responderia pelo crime do art.121 do Código Penal.

${ }^{352}$ De modo geral, entende-se pelo cometimento do crime de homicídio e não de participação em suicídio quando há a prática, pelo terceiro, de qualquer "ato executório" daquele crime. Cf., com outros exemplos, BITENCOURT, Cezar Roberto. op. cit., v. 2, p. 116. FRAGOSO, Heleno Cláudio. Lições de direito penal, cit., v. 1, p. 58. Tal distinção, entretanto, é fortemente criticada, sustentando a ideia de ser o homicídio a pedido simplesmente um suicídio com divisão de tarefas, por Frisancho (El suicidio y la autorresponsabilidad, p. 237-249) e Günther Jakobs. (Suicídio, eutanásia e direito penal. Barueri: Manole, 2003. p. 18 e seg.). Segundo este último autor, "o pedido é somente uma das muitas maneiras e modos com o qual uma pessoa que não quer viver mais pode organizar a sua morte, precisamente, por meio da divisão do trabalho" (op. cit., p. 23). Cf., ainda, JAKOBS, Günther. La organización de autolesión y heterolesión, especialmente en caso de muerte, cit., p. 395-412. 
para uma heterolesão consentida. Em ambas as hipóteses, no entanto, a intervenção penal revela simplesmente uma tentativa de proteger o indivíduo contra a sua vontade, uma imposição de um dever de viver, e, portanto, uma ilegítima atuação paternalista estatal ${ }^{353}$.

\footnotetext{
${ }^{353}$ No mesmo sentido: "Como não se podem impor concepções morais por meio do direito penal, a fundamentação histórica destes dispositivos com base na moral cristã não fornece legitimação suficiente para a punibilidade do auxílio a suicídio ou do homicídio a pedido da vítima. O único bem jurídico que, a meu ver, aqui se pode vislumbrar é a vida de uma pessoa que não age de modo completamente responsável, porque muitos suicídios não decorrem de uma decisão séria, mas, como meras instâncias do chamado suicídio de apelo, representam na verdade uma espécie de pedido de ajuda para os que estão em volta. A meu ver, uma reduzida punibilidade neste âmbito seria legitimável, se puníssemos o auxílio a um suicídio não fruto de reflexão madura e o homicídio a pedido de uma vítima ainda apta a agir de mão própria, porque neste caso, a própria incapacidade da vítima de levar a cabo sob si própria a decisão torna duvidosa a seriedade do desejo de morrer" (SCHÜNEMANN, Bernd. op. cit., p. 33-34). Numa linha semelhante, JAKOBS, Günther. Suicídio, eutanásia e direito penal, cit. Id. La organización de autolesión y heterolesión, especialmente en caso de muerte, cit., p. 395-412. Em sentido contrário, ressaltando ser "normalmente incompreensível" a conduta de dispor da própria vida, Eugênio Raúl Zaffaroni: "Uno de los problemas más complejos se plantea en el tipo de homicidio. Dado que se trata de casos de disposición radicalmente extremos del bien jurídico, la ley rodea la disposición de garantías que en el fondo son limitaciones, pero cuya validez constitucional no es cuestionable: tratándose de situaciones en que normalmente es incomprensible la conducta del sujeto, la ley opta por excluir la validez del consentimiento respecto de cualquier otro que no sea el titular del bien jurídico. De allí que no resulte contradictoria la tipificación de la instigación y ayuda al suicídio" (Derecho penal: parte general, cit., p. 498-499). Também nesse sentido, destacando, por sua vez, a importância do bem jurídico, a criação de tabus, e os problemas na aferição do consentimento, Claus Roxin: "Totalmente ineficaz es el consentimiento en el caso del bien jurídico individual vida humana. Aquí se infiere del § 216 que el consentimiento en la propia muerte no suprime la punibilidad del hecho, sino que, a lo sumo, la atenúa. Para ello existen buenos motivos.Un consentimento precipitado o influido por alteraciones psíquicas desconocidas puede causar daños irreparables, de modo que la víctima debe ser protegida también de sí misma; y la creación de tabúes respecto de cualquier muerte de un terceiro no justificada por legítima defensa consolida el respeto por la vida humana y sin duda alguna contribuye con ello a la protección de este supremo bien jurídico". (Derecho penal: parte general, cit., p. 529).
} 


\section{PRINCÍPIO DA AUTORRESPONSABILIDADE E TEORIA DA IMPUTAÇÃO DO RESULTADO}

Como já ressaltado, no modelo de Estado Constitucional de Direito, as normas constitucionais assumem o centro do sistema, devendo também a estrutura jurídica do delito - que, em última análise, determina os limites do poder punitivo estatal - ser por elas pautada, assimilando e incorporando o conteúdo do Estado Democrático de Direito, construindo, pois, um Direito Penal Constitucional-Democrático, sob pena de carência de legitimidade. No atual modelo de Estado, não há mais como estabelecer uma teoria do delito que ignore os preceitos democráticos.

Além de produzir forte impacto na teoria do consentimento, como exposto no capítulo anterior, o princípio constitucional da autorresponsabilidade acaba por assumir enorme relevância na chamada teoria da imputação do resultado, podendo ser esta, em linhas gerais, entendida como o estudo e a determinação do conjunto de critérios que possibilitem atribuir objetivamente um resultado - de lesão ou de perigo de lesão a bem jurídico-penal - a alguém como obra sua, e não de terceiros ${ }^{354}$.

Antes restrita à análise de uma relação de causalidade puramente natural, a teoria da imputação, na perspectiva da complexidade da chamada sociedade pós-industrial ou pós-moderna - entendida, numa determinada leitura, como sociedade de risco $^{355}$-, evolui no sentido de se adequar a esta nova realidade na dinâmica dos fatos, acrescentando-se novos critérios essencialmente normativos ao tipo objetivo, sendo estes englobados em uma denominada teoria da imputação objetiva do resultado ${ }^{356}$. Trata-se, na verdade,

\footnotetext{
${ }^{354}$ Segundo Juarez Tavares, "o processo de imputação deve ter como ponto de gravidade a consideração de que só será possível atribuir-se o injusto a alguém quando sua realização possa ser afirmada como obra sua e não de terceiros." (Teoria do injusto penal, cit., p. 252).

${ }^{355}$ BECK, Ulrich. Sociedade de risco: rumo a uma outra modernidade. São Paulo: Ed. 34, 2010. Segundo Miguel Reale Júnior, "na sociedade contemporânea, parafraseando Axel Mount, poderia-se dizer que o homem é uma ilha cercado de riscos por todos os lados: sob nossas cabeças os fios de eletricidade, sob nossos pés a rede de gás, à nossa frente o tráfego intenso de veículos, desde ambulâncias e carros de polícia a alta velocidade, as sempre presentes motos insinuantes, os caminhões de carga pesada ou inflamável, os postos de gasolina, os produtos tóxicos das indústrias, sem esquecer a casa, onde há aparelhos elétricos e o fogão a serem desligados, o botijão de gás. O homem forçosamente aprende a conviver com o risco e a tolerá-lo." (Instituições de direito penal, cit., p. 231).

${ }^{356} \mathrm{Cf}$., entre outros, ROXIN, Claus. Derecho penal: parte general, cit., p. 342 e seg. Id. Estudos de direito penal, cit., p. 101-131; Id. Funcionalismo e imputação objetiva. Rio de Janeiro: Renovar, 2002. p. 1-180. JESCHECK, Hans-Heinrich. op. cit., p. 248 e seg. GRECO, Luís. Um panorama da teoria da imputação objetiva. Rio de Janeiro: Lumen Juris, 2007. CAMARGO, Antônio Luís Chaves. Imputação objetiva e
} 
resumidamente, da introdução do elemento "risco" no âmbito da teoria da imputação, por meio de critérios negativos de atribuição ${ }^{357}$, com o escopo de, efetivamente, restringir a intervenção penal àqueles resultados lesivos que fundamentalmente decorram da conduta de um suposto autor ${ }^{358}$. Simplificadamente, segundo a teoria da imputação objetiva, em sua proposição mais difundida, um resultado só pode ser imputado a um indivíduo como obra sua quando o seu comportamento criar um risco não permitido para o objeto da ação, quando esse risco se realizar no resultado concreto e, por fim, quando tal resultado se encontrar dentro do alcance do tipo ${ }^{359}$.

No âmbito do presente trabalho, abdicando-se de um aprofundado estudo acerca da teoria da imputação ${ }^{360}$, em suas múltiplas formulações, importa afirmar que o princípio da autorresponsabilidade impacta diretamente aquelas hipóteses, tratadas pela teoria da imputação objetiva, em que o indivíduo se autocoloca em uma situação de risco ou, de alguma forma, consente para que aquela situação de risco se desenvolva. Aqui, diferentemente do que ocorre no que tange à chamada teoria do consentimento, estudada no capítulo anterior, o consentimento restringe-se simplesmente ao risco de produção do resultado lesivo, e não à sua efetiva produção.

Nessa linha, importante lembrar que o princípio constitucional da autorresponsabilidade assegura a cada indivíduo, no exercício do livre desenvolvimento da personalidade, a liberdade de autodeterminação, o que inclui, como já visto, a livre gestão de seus próprios bens jurídicos, segundo os seus desejos e convicções. Assim, da mesma forma que cada um é livre para lesionar seu próprio bem ou para consentir que outrem o faça, também é livre para expor seus bens a qualquer risco de lesão, com ou sem a participação de terceiros. Por essa razão, pode-se afirmar que, como regra, o eventual resultado lesivo que decorra diretamente dessa autocolocação em risco ou de uma

direito penal brasileiro. São Paulo: Cultura Paulista, 2001. Para uma visão crítica da teoria da imputação objetiva, cf. PASCHOAL, Janaína Conceição. Ingerência indevida: os crimes comissivos por omissão e o controle da punição do não fazer, cit., p. 131-140. No Brasil, já há decisões adotando a teoria da imputação objetiva. Cf., p. ex., STJ - HC 68.871 / PR. Rel.Maria Thereza de Assis Moura. Rel. p/ Acórdão Min. Og Fernandes. j.06/08/2009. STJ - REsp 822517 / DF. Rel.Min. Gilson Dipp. j.12/06/2007. STJ - HC 46.525 / MT. Rel.Min.Arnaldo Esteves Lima. j. 21/03/2006.

${ }^{357}$ TAVARES, Juarez. Teoria do injusto penal, cit., p. 278-279.

358، COm a imputação objetiva consegue-se atribuir juridicamente a determinado autor certo fato como "obra sua", através de critérios que, complementarmente ao nexo causal, consigam considerar a complexidade das relações sociais modernas”. (SALVADOR NETTO, Alamiro Velludo. Tipicidade penal e sociedade de risco. São Paulo: Quartier Latin, 2006. p. 178).

${ }^{359}$ ROXIN, Claus. Estudos de direito penal, cit., p. 104.

${ }^{360}$ Para tanto, pode-se tomar como ponto de partida o seguinte texto de Luís Greco: Imputação objetiva: uma introdução. In: ROXIN, Claus. Funcionalismo e imputação objetiva, cit., p. 1-180. 
heterocolocação em risco consentida, no atual modelo de Estado, somente pode ser imputado ao próprio titular do bem jurídico, e não ao terceiro interveniente, concluindose pela ilegitimidade da intervenção penal ${ }^{361}$. O resultado decorrente diretamente da ação livre e responsável do próprio titular do bem jurídico só pode ser imputado a este.

Na realidade, a incidência do poder punitivo estatal sobre aquele que terceiro que, de alguma forma, se relaciona com um o indivíduo que voluntariamente se expõe a uma situação de risco para seu próprio bem jurídico ou consente para que outrem conduza uma situação que exponha a perigo este mesmo bem, se revelaria como flagrante atuação paternalista estatal. Novamente, o Estado busca, por meio de seu poder punitivo, estabelecer padrões de conduta, distantes do risco de lesão, na tentativa de tutelar bens jurídicos individuais ainda que contra a vontade de seu titular.

Sendo assim, mesmo não havendo consentimento quanto ao resultado lesivo, também nessas situações, é possível afirmar a existência, ainda que em grau diverso, de um ato de livre disposição do próprio bem jurídico, o qual, como exaustivamente estudado, afasta a legitimidade da intervenção penal estatal ${ }^{362}$.

\footnotetext{
${ }^{361}$ Em sentido semelhante: "Diante de tal processo evolutivo, que culminou nas situações complexas criadas no âmbito da sociedade pós-industrial, passou-se a considerar que a vítima desempenha papel relevante no fato praticado pelo agente. Assim, quando o perigo decorre de sua própria consciência e vontade quanto ao risco assumido, não há que se falar em fato típico, passível de imputação ao autor. O fundamento da admissão da exclusão da tipicidade nesses causos repousa na teoria pessoal do bem jurídico. Com efeito, se o bem jurídico deve servir ao livre desenvolvimento do indivíduo no contexto social, não se pode afirmar a relevância jurídico-penal de sua lesão quando esta decorre de uma atitude de disposição de seu respectivo titular, considerada expressão de seu desenvolvimento. Tal fundamento encontra substrato no próprio texto constitucional, que estabelece o Brasil como Estado Democrático de Direito baseado na liberdade e na dignidade do indivíduo. Assim, os indivíduos titulares dos bens jurídicos, ao gozar de liberdade de ação para o fim de alcançar o desenvolvimento de sua personalidade, são imbuídos também de uma autorresponsabilidade, a determinar que o resultado decorrente da ação livre e responsável de alguém só pode ser imputado a este, e não àquele que o tenha anteriormente motivado." (BECHARA, Ana Elisa Liberatore Silva. Da teoria do bem jurídico como critério de legitimidade do direito penal, cit., p. 178179). "Tendo em vista o pluralismo de ideias, convicções e decisões acerca do agir, garantidas ao indivíduo como desdobramento da proteção à dignidade da pessoa humana, a intervenção do poder punitivo, a contrario sensu, só se pode legitimar na medida em que leve em consideração a separação das atividades de cada um sob a esfera da manifestação do próprio poder individual de autodeterminação. Isto quer dizer que a pessoa humana ao mesmo tempo em que tem assegurada a sua dignidade, como objeto de proteção do Estado, impõe a este uma limitação quanto ao processamento da responsabilidade alheia sobre a base da liberdade de agir. Assim, ninguém deverá ser responsabilizado porque outrem decidiu, por conta própria, atuar de outro modo, ainda que se submetendo aos riscos de sua atividade. Embora se reconheça ao Estado um importante papel na regulação da vida social, não lhe cabe, todavia, a função de tutor das atividades individuais. Esta é a consequência que decorre da consideração do princípio da autodeterminação como fundamento de um regime de liberdade e garantia." (TAVARES, Juarez. Teoria do crime culposo, cit., p. 370).

362،Um paternalismo estatal com intervenção do Direito Penal deveria ser admissível só no caso de falta de autonomia na pessoa do afetado. E isso deveria vigorar também para a dogmática jurídico-penal." (ROXIN, Claus. A proteção de bens jurídicos como função do direito penal, cit., p. 44).
} 
É claro que, a contrario sensu, poderá legitimar-se a imputação do resultado a este terceiro se o resultado lesivo advier diretamente de uma sua conduta que extrapole os limites do risco aceito pelo indivíduo lesionado. Cada indivíduo, por evidência, é o único legitimado a definir até que ponto deseja expor seu bem jurídico a perigo de lesão, trançando os limites da disposição, no exercício da livre gestão de seus bens.

No âmbito da teoria da imputação objetiva, tais hipóteses são tratadas, partindo do princípio da autorresponsabilidade ${ }^{363}$, no âmbito do critério normativo negativo cunhado de "alcance do tipo" "364, acima mencionado. Segundo esse critério, não haverá imputação quando o resultado, seja de lesão ou de perigo de lesão, da forma como ocorrido, se situar além dos limites do que é proibido, não se incluindo no âmbito de alcance do tipo ${ }^{365}$. $\mathrm{O}$ princípio da autorresponsabilidade funcionaria, assim, como limite a determinar o que é proibido, significando, na realidade, verdadeira delimitação do alcance do poder punitivo estatal, concretizada no seio do tipo objetivo. Dessa forma, quando o resultado lesivo decorrer

\footnotetext{
${ }^{363}$ Apoiando-se no princípio da autorresponsabilidade e valendo-se de critérios de imputação objetiva para solucionar esses grupos de casos, cf., ainda que com importantes variações, p. ex., TAVARES, Juarez. Teoria do crime culposo, cit., p. 370-378. Id. Teoria do injusto penal, cit., p. 288-298. CANCIO MELIÁ, Manuel. Conducta de la víctima e imputacíon objetiva em derecho penal, cit., p. 295 e seg. Id. La exclusión de la tipicidad por la responsabilidad de la víctima: imputación a la víctima, cit., p. 49-99. Id. Conducta de la victima e imputación objetiva. Revista de Derecho Penal, Montevideo, n. 2, p. 37-85, jul./dez. 2006. LÓPEZ DÍAZ, Claudia. op. cit., p. 384 e seg. ROXIN, Claus. Estudos de direito penal. Rio de Janeiro: Renovar, 2006. p. 101-131. SILVA SÁNCHEZ, Jesús María. La consideracion del comportamiento de la victima en la teoria juridica del delito, cit., p. 163-194. Partindo do princípio do livre desenvolvimento da personalidade, cf. BERDUGO GÓMEZ DE LA TORRE, Ignacio. op. cit., v. 2. De modo um pouco diverso, Günther Jakobs defende a exclusão da imputação, nesses casos, quando o resultado se encontre na esfera de competência da pretensa vítima. (Cf. JAKOBS. Günther. A imputação objetiva no direito penal. Tradução de André Luís Callegari. São Paulo: Ed. Revista dos Tribunais, 2000). Para uma crítica acerca da utilização do princípio da autorresponsabilidade, defendendo um critério de interpretação denominado "vitimodogmática", cf. SCHÜNEMANN, Bernd. El sistema del ilícito jurídico-penal: concepto de bien jurídico y victimodogmática como enlace entre el sistema de la parte general y la parte especial. Revista de Derecho Penal, Buenos Aires, n. 1, p. 97-133, 2003.

${ }^{364 ،}$ Neste setor se procede à análise das limitações impostas aos tipos de delito existentes na parte especial dos códigos penais. Cada delito, ao ser elaborado pelo legislador, comporta uma interpretação adequada a delimitar-lhe as respectivas zonas de injusto, situadas na perfeita identificação das exigências normativas quanto à lesão ou ao perigo de lesão do bem jurídico que lhes serve de substrato". (TAVARES, Juarez. Teoria do crime culposo, cit., p. 370). Alguns autores utilizam também as expressões "fim de proteção do tipo" ou "âmbito de proteção da norma". Cf., p. ex, BECHARA, Ana Elisa Liberatore Silva. Da teoria do bem jurídico como critério de legitimidade do direito penal, cit., p. 177 e seg. ROXIN, Claus. Derecho penal: parte general, cit., p. 386 e seg. MIR PUIG, Santiago. Derecho penal: parte general, cit., p. 264 e 304-305.

${ }^{365}$ Miguel Reale Júnior, reconhecendo ser a elaboração da teoria da imputação objetiva "relevante em uma sociedade de riscos como a pós-industrial", sobretudo em relação aos crimes culposos, destaca que o resultado deve ser aquele "que a norma visava evitar". (REALE JÚNIOR, Miguel. Instituições de direito penal, cit., p. 126. notas 9 e 10).
} 
diretamente da expressão da autorresponsabilidade do indivíduo, não haverá preenchimento do tipo objetivo e, portanto, carecerá de legitimidade qualquer intervenção penal ${ }^{366}$.

Normalmente, com o objetivo esclarecer a forma como se deve dar a utilização do critério, ou, até mesmo, como suporte à construção do próprio critério normativo ${ }^{367}$, trabalha-se com uma série de exemplos.

Em primeiro lugar, tem-se o caso de um traficante que vende heroína a um indivíduo. Os dois sabem que a injeção de certa quantidade de tóxico gera perigo de vida, mas assumem o risco de que a morte ocorra. O traficante o faz, porque o que lhe interessa é principalmente o dinheiro, e o indivíduo, por considerar a sua vida já estragada e só suportável sob estado de entorpecimento. Deve o traficante ser punido por homicídio cometido com dolo eventual, na hipótese de o indivíduo realmente injetar em si a droga e, em decorrência disso, morrer? ${ }^{368}$ Sustenta-se que a presença da causalidade natural e do dolo eventual seria evidente. No entanto, mesmo antes de se chegar à análise do tipo subjetivo, resta evidente que o resultado lesivo não pode ser imputado ao traficante, pois, nesse contexto de simples participação em uma autolesão, revela a expressão da liberdade de autodeterminação do indivíduo usuário da droga.

Há ainda a hipótese de alguém que, portador do vírus da AIDS, sem uso de preservativo, mantém relações sexuais com outro, o qual, conhecendo plenamente o perigo, também acaba se contaminando. Mesmo que haja, por parte do portador, o dolo de contaminação alheia, o resultado não poderá ser a ele imputado uma vez que é a própria suposta vítima que realiza consciente e deliberadamente a ação que a contamina,

\footnotetext{
${ }^{366}$ Vale notar que o Tribunal Constitucional alemão já teve a oportunidade de adotar a tese aqui esposada: ““'Autocolocações em perigo queridas e realizadas de modo auto-responsável não estão abrangidas no tipo de um delito de lesões corporais ou homicídio, ainda que o risco a que a vítima conscientemente se expôs se realize. Quem apenas provoca, possibilita ou facilita uma tal autocolocação em perigo não é punível por delito de lesões corporais ou homicídio." (BGHSt 32, p. 262 e SS, citado em: ROXIN, Claus. Funcionalismo e imputação objetiva, cit., p. 357-358. GRECO, Luís. Um panorama da teoria da imputação objetiva, cit., p. 63-64).

${ }^{367}$ Trata-se, muitas vezes, buscando-se alcançar uma formulação político-criminalmente desejável, de um método predominantemente indutivo que não se pretende adotar aqui. Neste trabalho, ao contrário, como já evidenciado, parte-se da construção de uma premissa maior - revelada pela afirmação do princípio constitucional da autorresponsabilidade - para um posterior estudo de seu impacto na atuação do poder punitivo estatal.

${ }^{368}$ ROXIN, Claus. Estudos de direito penal, cit., 2006, p. 101-131.
} 
no exercício de sua liberdade de autodeterminação, resolvendo-se, pois, a questão já no âmbito do tipo objetivo ${ }^{369}$.

Também se pode mencionar o caso de um alguém que convida um indivíduo para ser seu passageiro numa disputa de racha, espécie de competição automotiva que pressupõe a violação de uma série de regras de circulação viária e, consequentemente, o envolvimento de risco de lesão em grau elevado ${ }^{370}$. Caso o passageiro venha a ser lesionado, tal resultado, com base no princípio da autorresponsabilidade, não poderá ser imputado ao motorista, pelo que decorre de uma consciente exposição a risco, no exercício da livre gestão de bens jurídicos individuais.

Por fim, pode-se citar o exemplo de um viajante que solicita a um barqueiro que o leve para atravessar um rio durante uma tempestade. $\mathrm{O}$ barqueiro o desaconselha, alertando para todos os perigos, mas cede aos insistentes pedidos do passageiro, empreendendo a arriscada tentativa de travessia. Durante o trajeto, o barco se vira e o viajante morre afogado $^{371}$. Aqui, da mesma forma, não há como deixar de observar que o resultado morte decorre diretamente de uma voluntária e consciente autoexposição a risco, sendo, por essa razão, também ilegítima a sua imputação ao barqueiro sobrevivente.

Necessário observar, contudo, que cada caso ou grupo de casos, no âmbito de uma sociedade reveladora de relações cada vez mais complexas, pode compreender uma multiplicidade de desdobramentos que, eventualmente, possam ter o condão de conduzir a uma legítima intervenção penal ${ }^{372}$. De outro lado, não se ignora, também, que outros (sub) critérios negativos de imputação poderão ser utilizados para afastar a atuação do poder punitivo. O escopo deste trabalho, no presente momento, é apenas fixar as diretrizes para uma atuação do poder punitivo em consonância com o princípio constitucional da autorresponsabilidade, sem a pretensão de esgotar as quase infinitas possibilidades fáticas da realidade. O que é fundamental ter bem claro é que a intervenção penal estatal, no atual modelo de Estado, deve buscar sua base principal de justificação na

\footnotetext{
${ }^{369}$ Exemplo tratado em TAVARES, Juarez. Teoria do crime culposo, cit., p. 376-377 e em ROXIN, Claus. Derecho penal: parte general, cit., p. 396. Dessa forma, por evidência, é possível afirmar que o tipo de perigo de contágio venéreo (art.130 do $\mathrm{CP}$ ) pressupõe o desconhecimento da vítima quanto à existência da doença venérea de seu parceiro sexual.

${ }^{370}$ Exemplo semelhante ao trazido em : CAMARGO, Antonio Luis Chaves. Imputação objetiva e direito penal brasileiro. Boletim IBCCRIM, São Paulo, v. 9, n. 107, p. 7-9, out. 2001.

${ }^{371}$ Exemplo semelhante ao trazido em: ROXIN, Claus. Derecho penal: parte general, cit., p. 393 e seg.

${ }^{372}$ Um conhecimento especial do suposto autor em relação à pretensa vítima, p. ex., poderia, eventualmente, legitimar a intervenção penal, pelo que o resultado se encontraria além dos limites do risco aceito pela vítima.
} 
garantia da liberdade de autodeterminação do indivíduo, não se afigurando, pois, legítima uma intervenção que aponte justamente para a direção contrária, violando tal liberdade e, assim, o princípio da autorresponsabilidade. 


\section{CONCLUSÕES}

1. O sistema jurídico-normativo é composto por regras e princípios, ambos expressando mandamentos de “dever-ser". Os princípios jurídicos, diferentemente das regras, revelam mandados de otimização, o que significa que o comando nele consubstanciado deve ser realizado na maior medida possível, diante das possibilidades fáticas e jurídicas existentes. Além da eficácia interpretativa - que se coloca como vetor de interpretação dos demais atos normativos -, os princípios possuem eficácia positiva e negativa. A primeira, tradicionalmente atribuída às regras, tem o condão de reconhecer um direito subjetivo à realização dos efeitos da norma. A segunda permite que sejam declarados inválidos todos os atos ou normas que contravenham os efeitos pretendidos por um determinado princípio.

2. O Direito Penal, que tem como objeto a relação do indivíduo com o poder punitivo estatal, vincula-se diretamente ao modelo de Estado no qual se insere. Assim, qualquer estudo aprofundando acerca da legitimidade ou dos critérios de legitimidade da atuação desse poder de punir deve ter como pressuposto a análise da conformação política do Estado, em cada momento histórico.

3. No plano normativo, após a afirmação do Estado de Direito, verifica-se a passagem de um Estado Legal de Direito - marcado pelo "império da lei” para um Estado Constitucional de Direito - no qual a Constituição assume o centro do sistema, dotada de supremacia e força normativa imediata. Nesse cenário, todos os ramos do Direito passam a ser construídos e interpretados segundo o conteúdo do texto constitucional, sob pena de carência de legitimidade.

4. No que tange ao conteúdo, no âmbito do Estado de Direito, verifica-se, inicialmente, o estabelecimento do Estado Liberal de Direito, preocupado, sobretudo, com a afirmação de garantias fundamentais individuais frente ao autoritarismo do anterior Estado Absoluto. Em seguida, passa-se a um Estado Social de Direito, que, além de inaugurar um novo catálogo de direitos, visa conferir materialidade a direitos apenas formalmente afirmados, buscando 
superar as deficiências do modelo precedente. E, finalmente, como síntese dos modelos anteriores, chega-se ao Estado Democrático de Direito, irradiador do conteúdo democrático e, portanto, laico, multicultural, pluralista, tolerante perante todas as diferenças, consagrador de direitos difusos, e garantidor dos direitos fundamentais ainda que contra a vontade da maioria dos membros da sociedade.

5. Forma-se, assim, um modelo que pode ser chamado de Estado Constitucional e Democrático de Direito, Constitucional quanto ao sistema de vinculação normativa, e Democrático quanto ao conteúdo normativo, quanto aos valores consagrados, sendo este o modelo adotado no Brasil desde a Constituição de 1988.

6. O modelo de Estado Constitucional e Democrático de Direito, logicamente, acaba por influenciar a configuração do Direito Penal, o qual passa a ter como parâmetro de legitimidade justamente o conteúdo democrático estabelecido pela Constituição, formando o que pode ser denominado de Direito Penal Constitucional-Democrático, pautado, portanto, pelos princípios e regras constitucionais.

7. Dentre tais princípios e regras constitucionais, insere-se, como decorrência direta da adoção do modelo de Estado Democrático de Direito, o princípio da autorresponsabilidade, norma segundo a qual cada indivíduo se coloca como o único responsável por suas condutas, por suas escolhas, por sua forma de viver, desenvolvendo livremente a sua personalidade, como sujeito de sua própria história, no pleno exercício de sua autonomia. Com efeito, cada indivíduo deve ser também o único a suportar as consequências de seus próprios atos, não podendo tal responsabilidade ser atribuída a terceiros.

8. O princípio da autorresponsabilidade vincula-se diretamente ao direito fundamental à liberdade, à intimidade e à vida privada, tendo sido implicitamente adotado pela Constituição brasileira de 1988. Pode-se dizer que tal princípio, de aplicação geral e não exclusivamente penal, é concretizado em inúmero subprincípios, como o da liberdade de ação e de locomoção, da livre manifestação do pensamento, da liberdade de consciência e de crença, da liberdade de crença religiosa e de convicção filosófica e política, da liberdade 
de expressão intelectual, artística, científica e de comunicação, da liberdade de associação e de reunião, da livre de iniciativa econômica, da liberdade de exercício de qualquer trabalho, ofício ou profissão, e da liberdade e pluralismo no campo educacional.

9. No âmbito da relação Estado-indivíduo, o princípio da autorresponsabilidade liga-se diretamente às discussões que envolvem o chamado paternalismo estatal. Pode-se dizer que o Estado é paternalista quando atua visando proteger o indivíduo ignorando a sua vontade, pouco importando se este deseja ou não tal proteção, muitas vezes afirmando um padrão de conduta baseado em uma suposta concepção de "vida boa" ou de "vida moralmente recomendável". Agindo assim, o Estado - valendo-se de variados instrumentos, incluindo o seu poder punitivo penal - assume a posição de pater, de educador, infantilizando os cidadãos, partindo do pressuposto de que o indivíduo não é capaz de fazer adequadamente as suas próprias escolhas, e que, portanto, caberia ao Estado fazê-las, ou, minimamente, orientá-las.

10. No âmbito do Direito Penal, que deve ser Democrático-Constitucional, o princípio da autorresponsabilidade atua como critério negativo de legitimidade da atuação paternalista por meio do poder punitivo estatal, sobretudo considerando ser esta a forma mais grave de intervenção do Estado na esfera individual da pessoa - e que deve, pois, ser submetida aos mais rigorosos mecanismos de contenção -, e, ainda, o fato de ter o Direito Penal, neste modelo de Estado, como principal base de legitimação justamente a garantia da autonomia e do livre desenvolvimento do indivíduo.

11. O primeiro grande impacto do princípio da autorresponsabilidade no Direito Penal resulta na ilegitimidade dos chamados tipos penais paternalistas, os quais expandem o poder punitivo estatal a condutas que não lesionam ou exponham a risco de lesão qualquer bem jurídico alheio, ou que, mesmo na hipótese de lesão, desconsideram, por completo, a vontade do próprio indivíduo lesionado, muitas vezes, limitando-se a estabelecer supostos padrões de condutas moralmente dominantes. Como principais exemplos, pode-se citar as contravenções da vadiagem, da embriaguez e dos jogos de azar e do bicho, além de diversos crimes sexuais, dos crimes de charlatanismo e curandeirismo, 
dos crimes de uso e tráfico de drogas, do crime de comércio de tecido, órgãos ou parte do corpo humano, e do crime de participação em suicídio.

12. No âmbito da dogmática penal, o princípio da autorresponsabilidade deve provocar a reconstrução da chamada teoria do consentimento, superando-se o dogma da indisponibilidade de certos bens jurídicos individuais. No atual modelo de Estado, cada indivíduo tem o direito à livre gestão de seus próprios bens jurídicos, o que, logicamente, inclui a decisão acerca do destino de seu bem jurídico "vida", que teve a sua indisponibilidade levada à condição de verdadeiro tabu.

13. Por fim, verifica-se que o princípio da autorresponsabilidade provoca grande impacto também na chama teoria da imputação do resultado, afastando, mais uma vez, a atuação paternalista estatal, sobretudo nos casos de autocolocação em risco e de participação em autocolocação em risco. Valendo-se de critérios de imputação objetiva, o princípio da autorresponsabilidade atua como critério negativo do preenchimento do tipo objetivo, excluindo do alcance do tipo aqueles resultados decorrentes diretamente de uma ação livre e responsável do próprio indivíduo lesionado. 


\section{REFERÊNCIAS}

AGUILÓ REGLA, Josep. Del “império de la ley" al "estado constitucional”: dos paradigmas en pocas palabras. In: MOREIRA, Eduardo Ribeiro; PUGLIESI, Márcio (Coords.). 20 anos da Constituição brasileira. São Paulo: Saraiva, 2009. p. 97-109.

ALEXY, Robert. Los derechos fundamentales en el Estado Constitucional Democrático. In: CARBONELL, Miguel (Org.). Neoconstitucionalismo(s). 4. ed. Madrid: Trotta, 2009. p. 31-47.

Teoria dos direitos fundamentais. São Paulo: Malheiros Ed., 2008.

ANÁLISE da constitucionalidade sobre a incriminação do porte de drogas para consumo pessoal. Boletim IBCCRIM, São Paulo, ano 20, ed. esp., out. 2012. Disponível em: $<$ http://www.ibccrim.org.br/site/boletim/pdfs/Boletim239A.pdf>.

ANDRADE, Manuel da Costa. Consentimento e acordo em direito penal. Coimbra: Coimbra Ed., 2004.

Consentimento em direito penal médico: o consentimento presumido. Revista Portuguesa de Ciência Criminal, Coimbra, ano 14, n. 1/2, p. 117-148, 2004.

ANTOLISEI, Francesco. Manuale di diritto penale: parte generale. 14. ed. Milano: Giuffrè, 1997.

ÁVILA, Gustavo Noronha de; GAUER, Gabriel José Chittó; GAUER, Rita Maria Chittó. Comércio de órgãos humanos: até onde vai a autonomia do indivíduo? Boletim IBCCRIM, São Paulo, ano 15, n. 175, p. 17-19, jun. 2007.

ÁVILA, Humberto. Neoconstitucionalismo: entre a "Ciência do Direito" e o "Direito da Ciência”. Revista Brasileira de Direito Público, Belo Horizonte, ano 6, v. 23, 2008.

Teoria dos princípios. 10. ed. São Paulo: Malheiros Ed., 2009.

ÁVILA SANTAMARÍA, Ramiro. Del Estado legal de derecho al Estado constitucional de derechos y justicia. In: ELSNER, Gisela (Ed.). Anuario de derecho constitucional latinoamericano 2009. 15. ed. Montevidéu: Konrad-Adenauer-Stiftung, 2009. p. 775-793.

BANDEIRA DE MELLO, Celso Antônio. Curso de direito administrativo. 25. ed. São Paulo: Malheiros Ed., 2008. 
BAPTISTA, Patrícia. Transformações do direito administrativo. Rio de Janeiro: Renovar, 2003.

BARBERO SANTOS, Marino. Estado constitucional de derecho y sistema penal. Direito $e$ Cidadania, Praia, Cabo Verde, v. 3, p. 13-24, jul./fev. 2000/2001.

BARCELLOS, Ana Paula de. Neoconstitucionalismo, direitos fundamentais e controle das políticas públicas. In: SARMENTO, Daniel; GALDINO, Flávio (Orgs.). Direitos fundamentais. Rio de Janeiro: Renovar, 2006.

BARROSO, Luís Roberto. A Constituição brasileira de 1988: uma introdução. In: MARTINS, Ives Gandra da Silva; MENDES, Gilmar Ferreira; NASCIMENTO, Carlos Valder do (Orgs.). Tratado de direito constitucional. São Paulo: Saraiva, 2010. v. 1.

- Interpretação e aplicação da Constituição: fundamentos de uma dogmática constitucional transformadora. 7. ed. São Paulo: Saraiva, 2009.

Legitimidade da recusa de transfusão de sangue por testemunhas de Jeová: dignidade humana, liberdade religiosa e escolhas existenciais. Disponível em: $<$ http://www.luisrobertobarroso.com.br/wpcontent/themes/LRB/pdf/testemunhas_de_jeova.pdf $>$.

Neoconstitucionalismo e constitucionalização do direito: o triunfo tardio do direito constitucional no Brasil. Revista da Emerj, Rio de Janeiro, v. 9, n. 33, 2006.

BATISTA, Nilo. Introdução crítica ao direito penal brasileiro. 11. ed. Rio de Janeiro: Revan, 2007.

. Mídia e sistema penal no capitalismo tardio. Discursos Sediciosos, Rio de Janeiro, v. 12, n. 12, p. 271-289, 2002.

BECCARIA, Cesare. Dos delitos e das penas, de 1764. São Paulo: Ed. Revista dos Tribunais, 2006.

BECHARA, Ana Elisa Liberatore Silva. Da teoria do bem jurídico como critério de legitimidade do direito penal. Tese (Livre-Docência) - Faculdade de Direito da Universidade de São Paulo, 2011.

. Delitos sem bens jurídicos? Boletim IBCCRIM, São Paulo, ano 15, n. 181, p. 4-5, dez. 2007. 
BECHARA, Ana Elisa Liberatore Silva. Direitos humanos e direito penal: limites da intervenção penal racional no Estado Democrático de Direito. In: MENDES, Gilmar Ferreira; BOTTINI, Pierpaolo Cruz; PACELLI, Eugenio (Coords.). Direito penal contemporâneo: questões controvertidas. São Paulo: Saraiva, 2011. p. 153-194.

A prostituição deve ser legalizada? Sim. Revista da OAB, São Paulo, v. 373, p. 12$12,2012$.

BECK, Ulrich. Sociedade de risco: rumo a uma outra modernidade. São Paulo: Ed. 34, 2010.

BERDUGO GÓMEZ DE LA TORRE, Ignacio. El consentimiento en las lesiones veinte años después. In: NIETO MARTÍN, Adán. Homenaje al Dr. Marino Barbero Santos in memorian II. Cuenca: Ediciones de la Universidad de Castilla-La Mancha: Universidad Salamanca, 2001. v. 2.

BETTIOL, Giuseppe. Direito penal. São Paulo: Ed. Revista dos Tribunais, 1966. v. 1.

BITENCOURT, Cezar Roberto. Tratado de direito penal. 13. ed. São Paulo: Saraiva, 2008. v. 1.

Tratado de direito penal. 8. ed. São Paulo: Saraiva, 2008. v. 2.

Tratado de direito penal. 3. ed. São Paulo: Saraiva, 2008. v. 4.

BOITEUX, Luciana. Breves considerações sobre a política de drogas brasileira atual e as possibilidades de descriminalização. Boletim IBCCRIM, São Paulo, ano 18, n. 217, p. 16, dez. 2010.

; WIECKO, Ela; BATISTA; Vanessa; PRADO, Geraldo (Coords.). Tráfico de drogas e Constituição. Brasília-DF: Ministério da Justiça, 2009.

BONAVIDES, Paulo. Curso de direito constitucional. 12. ed. São Paulo: Malheiros Ed., 2002.

Do Estado liberal ao Estado social. 10. ed. São Paulo: Malheiros Ed., 2011.

BORGES, Luiz Guilherme de Melo. A relação jurídica de consumo sob o prisma do paternalismo jurídico. 2010. Dissertação (Mestrado) - Faculdade Milton Campos, Nova Lima, 2010.

BOTTINI, Pierpaolo Cruz. Crimes de perigo abstrato. 2. ed. São Paulo: Ed. Revista dos Tribunais, 2010. 
CAMARGO, Antonio Luis Chaves. Imputação objetiva e direito penal brasileiro. Boletim IBCCRIM, São Paulo, v. 9, n. 107, p. 7-9, out. 2001.

. Imputação objetiva e direito penal brasileiro. São Paulo: Cultura Paulista, 2001.

CAMPOS, Marcelo da Silveira. Crime e Congresso Nacional: uma análise da política criminal aprovada de 1989 a 2006. São Paulo: IBCCRIM, 2010.

CANCIO MELIÁ, Manuel. Conducta de la victima e imputación objetiva. Revista de Derecho Penal, Montevideo, n. 2, p. 37-85, jul./dez. 2006.

Conducta de la víctima e imputacíon objetiva em derecho penal. Bogotá: Bosch. 2001.

La exclusión de la tipicidad por la responsabilidad de la víctima: imputación a la víctima. Revista de Derecho Penal y Criminología, Madrid, n. 2, p. 49-99, jul. 1998.

CANOTILHO, J. J Gomes. Direito constitucional. Coimbra: Almedina, 2003.

CARBONELL, Miguel (Org.). Neoconstitucionalismo(s). 4. ed. Madrid: Trotta, 2009.

CARUSO FONTÁN, Viviana. Sobre la criminalización de las actividades relacionadas con la prostitución consentida. Revista de Derecho y Proceso Penal, Navarra, v. 1, n. 25, p. 3144, 2011.

CARVALHO, Salo de. A política criminal de drogas no Brasil. 5. ed. Rio de Janeiro: Lumen Juris, 2010.

CERVINI, Raul. Prefácio. In: PIERANGELI, José Henrique; SOUZA, Carmo Antônio de. Crimes sexuais. Belo Horizonte: Del Rey, 2010.

COSTA, Helena Regina Lobo da. A dignidade humana: teoria da prevenção geral positiva. São Paulo: Ed. Revista dos Tribunais, 2008.

COSTA, José de Faria; GODINHO, Inês Fernandes (Orgs.). As novas questões em torno da vida e da morte no direito penal. Coimbra: Coimbra Ed., 2010.

D’ÁVILA, Fábio Roberto. Ofensividade em direito penal: escritos sobre a teoria do crime como ofensa a bens jurídicos. Porto Alegre: Livr. do Advogado, 2009.

DIAS, Jorge de Figueiredo. Direito penal: parte geral. São Paulo: Ed. Revista dos Tribunais, 2007. 
DIAS, Roberto. $O$ direito fundamental à morte digna: uma visão constitucional da eutanásia. Belo Horizonte: Fórum. 2012.

DIAS NETO, Theodomiro. O direito à vida e o direito penal. Folha de S. Paulo, São Paulo, p. A3, 20 jan. 2005.

DÍAZ, Eliás. Estado de derecho y sociedad democrática. In: DE GIORGI, Raffaele (Org.). Il diritto e la differenza. Lecce: Pensa Multimedia, 2002.

DÍEZ RIPOLLÉS, José Luis. Alternativas a la actual legislación sobre drogas. Cuadernos de Política Criminal, Madrid, n. 46, 1992.

El objeto de protección del nuevo derecho penal sexual. Revista de Derecho Penal y Criminología, Madrid, 2. época, n. 6, p. 69-101, jul. 2000.

DI GIOVINE, Ombreta. Il contributo della vittima nel delitto colposo. Torino: Giappichelli, 2003.

DWORKIN, Gerald. Paternalism. In: SARTORIUS, Rolf (Ed.). Paternalism. Minneapolis: University of Minnesota Press, 1983.

DWORKIN, Ronald. Domínio da vida: aborto, eutanásia e liberdades individuais. São Paulo: Martins Fontes, 2009.

Levando os direitos a sério. São Paulo: Martins Fontes, 2010.

ESTELLITA, Heloisa. Paternalismo, moralismo e direito penal: alguns crimes suspeitos em nosso direito positivo. Revista Brasileira de Filosofia, São Paulo, v. 56, n. 227, p. 333 $341,2007$.

FEINBERG, Joel. Harm to others: the moral limits of criminal law. New York: Oxford University Press, 1984. v. 1.

Harm to self: the moral limits of criminal law. New York: Oxford University Press, 1986. v. 3.

FELDENS, Luciano. A conformação constitucional do direito penal. In: WUNDERLICH, Alexandre (Coord.). Política criminal contemporânea: criminologia, direito penal e direito processual penal: homenagem do Departamento de Direito Penal e Processual Penal pelos 60 anos da Faculdade de Direito da PUC/RS. Porto Alegre: Livr. do Advogado, 2008.

A Constituição penal: a dupla face da proporcionalidade no controle de normas penais. Porto Alegre: Livr. do Advogado, 2005. 
FERRAJOLI, Luigi. Democracia y garantismo. 2. ed. Madrid: Trotta, 2010.

Direito e razão: teoria do garantismo penal. 2. ed. São Paulo: Ed. Revista dos Tribunais, 2006.

O Estado constitucional de direito hoje: o modelo e a sua discrepância com a realidade. Revista do Ministério Público de Lisboa, n. 67, v. 17, p. 39-56, 1996.

. Pasado y futuro del Estado de derecho. In: CARBONELL, Miguel (Org.). Neoconstitucionalismo(s). 4. ed. Madrid: Trotta, 2009.

. Sobre el papel cívico y político de la ciencia penal en el Estado constitucional de derecho. Nueva Doctrina Penal, Buenos Aires, A, p. 63-71, 1998.

FRAGOSO, Heleno Cláudio. Aspectos legais da toxicomania. Revista Brasileira de Criminologia e Direito Penal, Rio de Janeiro, v. 2, n. 8, p. 85-100, jan./mar. 1965.

Lições de direito penal. São Paulo: Bushatsky, 1959. v. 3.

FRANCO, Alberto Silva. Crimes hediondos. 6. ed. rev. atual. e ampl. São Paulo: Ed. Revista dos Tribunais, 2007. $605 \mathrm{p}$.

; STOCO, Rui (Coords.). Código Penal e sua interpretação. São Paulo: Ed. Revista dos Tribunais, 2007. $1824 \mathrm{p}$.

GARCÍA-PELAYO, Manuel. Estado legal e Estado constitucional de derecho. Revista de la Facultad de Ciencias Jurídicas y Políticas, Caracas, n. 82, p. 32-45, 1991.

. Las transformaciones del Estado contemporáneo. Madrid: Alianza Editorial, 2005.

GOMES, Luiz Flávio. Jogo do bicho: bem jurídico e descriminalização parcial. Boletim IBCCRIM, São Paulo, n.56, p. 5, jul. 1997.

et. al. Lei de drogas comentada. 2. ed. São Paulo: Ed. Revista dos Tribunais, 2007.

GRECO, Alessandra Orcesi Pedro; RASSI, João Daniel. Crimes contra a dignidade sexual. São Paulo: Atlas, 2010.

GRECO, Luís. Casa de prostituição (art. 229 do CP) e direito penal liberal: reflexões por ocasião do recente julgado do STF (HC 104.467). Revista Brasileira de Ciências Criminais, São Paulo, v. 19, n. 92, set./out. 2011. 
GRECO, Luís. Imputação objetiva: uma introdução. In: ROXIN, Claus. Funcionalismo e imputação objetiva. Rio de Janeiro: Renovar, 2002. p. 1-180.

. Um panorama da teoria da imputação objetiva. Rio de Janeiro: Lumen Juris, 2007.

Posse de droga, privacidade, autonomia: reflexões a partir da decisão do Tribunal Constitucional argentino sobre a inconstitucionalidade do tipo penal de posse de droga com a finalidade de próprio consumo. Revista Brasileira de Ciências Criminais, São Paulo, v. 18, n. 87, p. 84-102, nov./dez. 2010.

Princípio da ofensividade e crimes de perigo abstrato: uma introdução ao debate sobre o bem jurídico e as estruturas do delito. Revista Brasileira de Ciências Criminais, São Paulo, v. 12, n. 49, p. 89-147, jul./ago. 2004.

Tem futuro a teoria do bem jurídico? Reflexões a partir da decisão do Tribunal Constitucional Alemão a respeito do crime de incesto ( $\$ 173$ Strafgesetzbuch). Revista Brasileira de Ciências Criminais, São Paulo, v. 18, n. 82, p. 165-185, jan./fev. 2010.

. Tipos de autor e lei de tóxicos ou interpretando democraticamente uma lei autoritária. Revista Brasileira de Ciências Criminais, São Paulo, v. 11, n. 43, abr.jun. 2003.

; TÓRTIMA, Fernanda Lara (Orgs.). O bem jurídico como limitação ao poder estatal de incriminar? Rio de Janeiro: Lumen Juris, 2011.

GRECO, Rogério. Curso de direito penal: parte geral. Niterói: Impetus, 2008.

GRECO FILHO, Vicente; RASSI, João Daniel. Lei de drogas anotada: Lei $\mathrm{n}$. 11.343/2006. 2. ed. São Paulo: Saraiva. 2008.

GUASTINI, Riccardo. La "Constitucionalizacíon" del Ordenamiento Jurídico: el Caso Italiano. In: CARBONELL, Miguel (Org.). Neoconstitucionalismo(s). 4. ed. Madrid: Trotta, 2009.

HASSEMER, Winfried. Direito penal: fundamentos, estrutura e política. Porto Alegre: Safe, 2008.

Introdução aos fundamentos do direito penal. Porto Alegre: Safe, 2005. 
HEFENDEHL, Roland. O bem jurídico como pedra angular da norma penal. In: GRECO, Luís; TÓRTIMA, Fernanda Lara (Orgs.). O bem jurídico como limitação ao poder estatal de incriminar? Rio de Janeiro: Lumen Juris, 2011. p. 57-75.

. Uma teoria social do bem jurídico. Revista Brasileira de Ciências Criminais, São Paulo, v. 18, n. 87, p. 103-120, nov./dez. 2010.

(Ed.). La teoría del bien jurídico: fundamento de legitimación del derecho penal o juego de abalorios dogmático? Madrid: Marcial Pons, 2007.

HERRERA MORENO, Myrian. La hora de la víctima. Madrid: Edersa, 1996.

HESSE, Konrad. A força normativa da Constituição. Porto Alegre: Safe, 1991.

HIRSCH, Andrew von. Paternalismo direto: autolesões devem ser punidas penalmente? Revista Brasileira de Ciências Criminais, São Paulo, v. 15, n. 67, jul./ago. 2007.

JAKOBS, Günther. A imputação objetiva no direito penal. Tradução de André Luís Callegari. São Paulo: Ed. Revista dos Tribunais, 2000.

La organización de autolesión y heterolesión, especialmente en caso de muerte. In: JAKOBS, Günther. Estudios de derecho penal. Madrid: Civitas, 1997.

. Suicídio, eutanásia e direito penal. Barueri: Manole, 2003.

JESCHECK, Hans-Heinrich. Tratado de derecho penal: parte general. 4. ed. Granada: Comares, 1993.

JESUS, Damásio de. Lei antidrogas anotada. 9. ed. São Paulo: Saraiva, 2009.

KARAM, Maria Lúcia. Drogas: a irracionalidade da criminalização. Boletim IBCCRIM, São Paulo, n.45, p. 09-10, ago. 1996.

A Lei n. 11.343/06 e os repetidos danos do proibicionismo. Boletim IBCCRIM, São Paulo, v. 14, n. 167, p. 6-7, out. 2006.

LOPES JUNIOR, Aury. Direito processual penal e sua conformidade constitucional. 7. ed. Rio de Janeiro: Lumen Juris, 2011. v. 1 e 2.

LÓPEZ DÍAZ, Claudia. Acciones a próprio risco. Bogotá: Universidad Externado de Colombia, 2006.

LUISI, Luiz. Os princípios constitucionais penais. 2. ed. Porto Alegre: Safe, 2003. 
MARCÃO, Renato. Tóxicos. 4. ed. São Paulo: Saraiva, 2007.

MARINHO, Renato Silvestre. A relevância do comportamento da vítima no direito penal: novos caminhos. Boletim IBCCRIM, São Paulo, v. 18, p. 12-13, 2010.

MARINUCCI, Giorgio; DOLCINI, Emilio. Constituição e escolhas de bens jurídicos. Revista Portuguesa de Ciência Criminal, Coimbra, v. 4, n. 2, p. 151-198, abr./jun. 1994.

; __. Manuale di diritto penale. 3. ed. Milano: Giuffrè, 2009.

MARTINELLI, João Paulo Orsini. Paternalismo jurídico-penal. 2010. Tese (Doutorado) Faculdade de Direito, Universidade de São Paulo, São Paulo, 2010.

. Paternalismo na lei de drogas. Revista Liberdades, São Paulo, n. 2, p. 13-24, set./dez. 2009.

MARTINS-COSTA, Judith (Org.). A reconstrução do direito privado: reflexos dos princípios, diretrizes e direitos fundamentais constitucionais no direito privado. São Paulo: Ed. Revista dos Tribunais, 2002.

; MOLLER, Letícia Ludwig (Orgs.). Bioética e responsabilidade. Rio de Janeiro: Forense, 2009.

MEDINA FRISANCHO, José Luis. El suicidio y la autorresponsabilidad. In: MEDINA FRISANCHO, José Luis. Eutanásia e imputación objetiva en derecho penal: una interpretación normativa de los ámbitos de responsabilidad en la decisión de la propia muerte. Lima: Ara, 2010.

MENDES, Gilmar Ferreira et al. Curso de direito constitucional. São Paulo: Saraiva: 2008. et al. Curso de direito constitucional. 7. ed. São Paulo: Saraiva: 2012.

MILL, John Stuart. Sobre a liberdade. Lisboa: Edições 70, 2006.

MIR PUIG, Santiago. Constitución, derecho penal y globalización. In: MIR PUIG, Santiago; CORCOY BIDASOLO, Mirentxu (Dir.); GÓMEZ MARTÍN, Víctor (Coord.). Nuevas tendencias en política criminal: una auditoría al Código Penal español de 1995. Montevidéu: B. de F. Julio César Faira, 2006. p. 115-126.

Derecho penal: parte general. 9. ed. Madrid: Reppertor, 2012. 
MIR PUIG, Santiago. La nueva constitución española y el derecho penal: fundamento constitucional de la pena y teoría del delito. Doctrina Penal: teoría y prática en las ciencias penales, Buenos Aires, v. 2, 5/8, p. 525-560, 1979.

. Revisión de la teoría del delito en un estado social y democrático de derecho. In: BELLO RENGIFO, Carlos Simón; ROSALES, Elsie (Comp.). Libro homenaje a José Rafael Mendoza Troconis. Caracas: Instituto de Ciencias Penales y Criminológicas; Facultad de Ciencias Jurídicas y Políticas; Universidad Central de Venezuela, 1998. v. 2, p. 195-218.

MOCCIA, Sergio. Emergência e defesa dos direitos fundamentais. Revista Brasileira de Ciências Criminais, São Paulo, v. 7, n. 25, p. 58-91, jan./mar. 1999.

MONTEIRO, Marcelo Valdir. Lei das Contravenções Penais - parte especial - capítulo VII: das contravenções referentes à política de costumes - arts. 50 a 58. In: SALVADOR NETTO, Alamiro Velludo (Coord.). Comentários à Lei das Contravenções Penais. São Paulo: Quartier Latin, 2006. p. 235-236.

MORAES, Maria Celina Bodin de. A caminho de um direito civil constitucional. Revista de Direito Civil Imobiliário, Agrário e Empresarial, São Paulo, n. 65, p. 21-32, 2003.

MORAES FILHO, Antonio Evaristo de; LAVIGNE, Arthur; RIBEIRO, Paulo Freitas. Crime de curandeirismo e liberdade de culto (trabalho forense). Revista Brasileira de Ciências Criminais, São Paulo, v. 1, n. 2, p. 255-277, abr./jun. 1993.

MOREIRA, Eduardo Ribeiro. Neoconstitucionalismo: a invasão da Constituição. São Paulo: Método, 2008.

MOREIRA, Rene. Justiça nega habeas corpus em favor de morador de rua. Disponível em: <http://veja.abril.com.br/noticia/brasil/justica-nega-habeas-corpus-em-favor-demorador-de-rua>. Acesso em: 07 jun. 2012.

MOURAZ LOPES, José Antonio. Os crimes contra a liberdade sexual no Código Penal Português após a revisão de 1995. Revista Brasileira de Ciências Criminais, São Paulo, n. 10, p. 47-51, 1995.

MUÑOZ CONDE, Francisco; AUNION ACOSTA, Bella. Drogas y derecho penal. Eguzkilore: Cuaderno del Instituto Vasco de Criminología, San Sebastian, n. 5, p. 147-157, dez. 1991.

NUCCI, Guilherme de Souza. Código Penal comentado. 8. ed. São Paulo: Ed. Revista dos Tribunais, 2008. 
NUCCI, Guilherme de Souza. Leis penais e processuais penais comentadas. 3. ed. São Paulo: Ed. Revista dos Tribunais, 2008.

NÚÑEZ PAZ, Miguel Ángel. Homicidio consentido, eutanasia y derecho a morrir com dignidad. Madrid: Tecnos, 1999.

PALAZZO, Francesco. Direito penal e Constituição na experiência italiana. Revista Portuguesa de Ciência Criminal, Coimbra, v. 9, n. 1, p. 31-44, jan./mar. 1999.

_ Estado constitucional de derecho y derecho penal. Revista Penal, n. 2, p. 49-60, 1998.

. Valores constitucionais e direito penal. Porto Alegre: Safe, 1989.

PASCHOAL, Janaina Conceição. Constituição, criminalização e direito penal mínimo. São Paulo: Ed. Revista dos Tribunais, 2003.

A importância do encontro sobre drogas: aspectos penais e criminológicos. In: REALE JÚNIOR, Miguel (Coord.). Drogas: aspectos penais e criminológicos. Rio de Janeiro: Forense, 2005.

Ingerência indevida: os crimes comissivos por omissão e o controle da punição do não fazer. Porto Alegre: Safe, 2011.

; REALE JÚNIOR, Miguel. Auxílio ao suicídio, infanticídio e aborto. In: REALE JÚNIOR, Miguel (Org.). Direito penal: jurisprudência em debate: crimes contra a pessoa. Rio de Janeiro: GZ, 2011. v 1, p. 46-55.

PIERANGELI, José Henrique. Códigos penais do Brasil: evolução histórica. 2. ed. São Paulo: Ed. Revista dos Tribunais, 2001.

O consentimento do ofendido na teoria do delito. 3. ed. São Paulo: Ed. Revista dos Tribunais, 2001.

; SOUZA, Carmo Antônio de. Crimes sexuais. Belo Horizonte: Del Rey, 2010.

PRADO, Luiz Regis. Bem jurídico-penal e Constituição. São Paulo: Ed. Revista dos Tribunais, 2009.

. Curso de direito penal brasileiro. 7. ed. rev. atual. e ampl. São Paulo: Ed. Revista dos Tribunais, 2008. v. 2. 
PRADO, Luiz Regis. Curso de direito penal brasileiro. 7. ed. rev. atual. e ampl. São Paulo: Ed. Revista dos Tribunais, 2007. v. 3.

REALE JÚNIOR, Miguel. Caminhos do direito penal brasileiro. Revista Brasileira de Ciências Criminais, São Paulo, v. 18, n. 85, p. 41-76, jul./ago. 2010.

. Discursos sobre o Brasil. São Paulo: Saraiva, 2012.

. A inconstitucionalidade da lei dos remédios. Revista dos Tribunais, São Paulo, v. 88, n. 763, p. 415-431, 1999.

. Instituições de direito penal. 3. ed. São Paulo: Saraiva, 2009.

. Morte digna. In: REALE JÚNIOR, Miguel. Discursos sobre o Brasil. São Paulo: Saraiva, 2012. p. 245-248.

Paternalismo no Brasil. Revista Brasileira de Filosofia, São Paulo, n. 227, p. 287319, 2007.

. Prefácio. In: SALVADOR NETTO, Alamiro Velludo (Coord.). Comentários à Lei das Contravenções Penais. São Paulo: Quartier Latin, 2006.

. Quebrando o tabu. O Estado de S. Paulo, São Paulo, 02 jul. 2011.

. Razão e subjetividade no direito penal. Revista da Associação Brasileira de Professores de Ciências Penais, São Paulo, v. 1, n. 0, p. 226-249, jan./jun. 2004.

(Coord.). Direito penal: jurisprudência em debate: crimes contra a pessoa. Rio de Janeiro: GZ, 2011. v 1.

(Coord.). Direito penal: jurisprudência em debate: dos crimes contra a saúde pública. Rio de Janeiro: GZ, 2012. v. 3.

(Coord.). Drogas: aspectos penais e criminológicos. Rio de Janeiro: Forense, 2005.

RIGOPOULOU, Maria. Traços paternalistas no direito penal da atualidade. Revista Brasileira de Filosofia, São Paulo, n. 227, 2007.

ROSENFIELD, D. L. Democracia e liberdade de escolha. Revista de Opinião Filosófica, v. 1, p. 1-39, 2010.

Informar e tutelar. O Estado de S. Paulo, São Paulo, 08 out. 2012. p. A2.

ROSSEAU, Jean-Jaques. O contrato social. São Paulo: Martins Fontes, 1999. 
ROXIN, Claus. Derecho penal: parte general. Madrid: Civitas. 1997.t. 1.

. Estudos de direito penal. Rio de Janeiro: Renovar, 2006.

. Estudos de direito penal. 2. ed. Rio de Janeiro: Renovar, 2008.

. Funcionalismo e imputação objetiva. Rio de Janeiro: Renovar, 2002.

El legislador no lo puede todo. Iter Criminis: revista de ciencias penales, México, n. 12 , out./mar. 2004/2005.

. A proteção de bens jurídicos como função do direito penal. 2. ed. Porto Alegre:

Livr. do Advogado, 2009.

. Sobre o recente debate em torno do bem jurídico. In: GRECO, Luís; TÓRTIMA, Fernanda Lara (Orgs.). O bem jurídico como limitação ao poder estatal de incriminar? Rio de Janeiro: Lumen Juris, 2011.

SÁ, Alvino Augusto de. Sonhando com o "fim do tráfico" de entorpecentes. Boletim IBCCRIM, São Paulo, ano 18, n. 211, p. 4-6, jun., 2010.

SALVADOR NETTO, Alamiro Velludo. Estupro bilateral: um exemplo limite. Boletim IBCCRIM, São Paulo, ano 17, n. 202, p. 8-9, set. 2009.

. Tipicidade penal e sociedade de risco. São Paulo: Quartier Latin, 2006.

(Coord.). Comentários à Lei das Contravenções Penais. São Paulo: Quartier Latin, 2006.

SARMENTO, Daniel. Direitos fundamentais e relações privadas. 2. ed. Rio de Janeiro: Lumen Juris, 2006.

O neoconstitucionalismo no Brasil: riscos e possibilidades. In: LEITE, George Salomão; SARLET, Ingo Wolfgang (Orgs.). Direitos fundamentais e Estado constitucional. São Paulo: Ed. Revista dos Tribunais; Coimbra: Coimbra Ed., 2009. p. 9-49.

; GALDINO, Flávio (Orgs.). Direitos fundamentais. Rio de Janeiro: Renovar, 2006.

SCHRITZMEYER, Ana Lúcia Pastore. Direito e antropologia: uma história de encontros e desencontros: julgamentos de curandeirismo e charlatanismo (Brasil - 1900/1990). Revista Brasileira de Ciências Criminais, São Paulo, v. 5, n. 18, abr./jun. 1997. 
SCHÜNEMANN, Bernd. O direito penal é a ultima ratio da proteção de bens jurídicos: sobre os limites invioláveis do direito penal em um estado de direito liberal. Revista Brasileira de Ciências Criminais, São Paulo, v. 13, n. 53, p. 9-37, mar./abr. 2005.

. El sistema del ilícito jurídico-penal: concepto de bien jurídico y victimodogmática como enlace entre el sistema de la parte general y la parte especial. Revista de Derecho Penal, Buenos Aires, n. 1, p. 97-133, 2003.

SILVA, José Afonso da. Curso de direito constitucional positivo. 33. ed. São Paulo: Malheiros Ed., 2009.

SILVA, Virgílio Afonso da. A constitucionalização do direito: os direitos fundamentais nas relações entre particulares. São Paulo: Malheiros Ed., 2005.

. Direitos fundamentais. São Paulo: Malheiros Ed., 2010.

SILVA FORNÉ, Diego. Juegos de azar, tutela penal de la propiedad y delito de juego de la mosqueta. Revista de Derecho Penal, Fundación de Cultura Universitária, Montevideo, n. 12, p. 87-102, jul. 2001.

SILVA SÁNCHEZ, Jesús María. La consideracion del comportamiento de la victima en la teoria juridica del delito. Revista Brasileira de Ciências Criminais, São Paulo, v. 9, n. 34, p. 163-194, abr./jun. 2001.

. A expansão do direito penal. 2. ed. São Paulo: Ed. Revista dos Tribunais, 2011.

SILVEIRA, Renato de Mello Jorge. Crimes sexuais. São Paulo: Quartier Latin, 2008.

Direito penal supra-individual. São Paulo: Ed. Revista dos Tribunais, 2003.

Dos crimes contra a dignidade sexual. In: REALE JÚNIOR, Miguel. (Coord.). Direito penal: jurisprudência em debate: dos crimes contra a saúde pública. Rio de Janeiro: GZ, 2012. v. 3.

Lei das Contravenções Penais - parte especial - capítulo VII: das contravenções referentes à política de costumes - arts. 59 a 65. In: SALVADOR NETTO, Alamiro Velludo (Coord.). Comentários à Lei das Contravenções Penais. São Paulo: Quartier Latin, 2006. p. 271-296.

Por um novo direito penal sexual: a moral e a questão da honestidade. Revista Brasileira de Ciências Criminais, São Paulo, v. 9, n. 33, p. 133-158, jan./mar. 2001. 
SOUZA, Luciano Anderson de. Punição criminal ao porte de entorpecentes para uso próprio e irracionalismo repressivo: uma ainda necessária reflexão. Revista Brasileira de Ciências Criminais, São Paulo, v. 19, n. 88, p. 167-186, jan./fev. 2011.

STANCIOLI, Brunello. Renúncia ao exercício dos direitos da personalidade ou como alguém pode se tornar o que quiser. Belo Horizonte: Del Rey, 2010.

TAVARES, André Ramos. Princípios constitucionais. In: MARTINS, Ives Gandra da Silva; MENDES, Gilmar Ferreira; NASCIMENTO, Carlos Valder do (Orgs.). Tratado de direito constitucional. São Paulo: Saraiva, 2010. v. 1.

TAVARES, Juarez. Prefácio. In: PASCHOAL, Janaina Conceição. Constituição, criminalização e direito penal mínimo. São Paulo: Ed. Revista dos Tribunais, 2003.

. Teoria do crime culposo. 3. ed. Rio de Janeiro: Lumen Juris, 2009.

Teoria do injusto penal. 3. ed. Belo Horizonte: Del Rey, 2003.

TEPEDINO, Gustavo. Temas de direito civil. Rio de Janeiro: Renovar, 2004.

(Coord.). Problemas de direito civil-constitucional. Rio de Janeiro: Renovar, 2000.

TOLEDO, Francisco de Assis. Princípios básicos de direito penal. 5. ed. São Paulo: Saraiva, 1994.

VIANNA, Túlio. O direito ao próprio corpo. Fórum, São Paulo, p. 18-19, 10 jan. 2012. Legalizar as casas de prostituição. Fórum, São Paulo, p. 18-19, 10 nov. 2011. Sobre o direito à própria morte. Fórum, São Paulo, p. 14-15, 10 set. 2012.

ZAFFARONI, Eugenio Raúl. Conferência Ministro Eugenio Raúl Zaffaroni. In: KARAM, Maria Lúcia (Org.). Globalização, sistema penal e ameaças ao Estado Democrático de Direito. Rio de Janeiro: Lumen Juris, 2005.

. Derecho penal: parte general. 2. ed. Ediar: Buenos Aires, 2002.

O inimigo no direito penal. 2. ed. Rio de Janeiro: Revan, 2007.

; BATISTA, Nilo. Direito penal brasileiro. Rio de Janeiro: Revan, 2003. v. 1. 